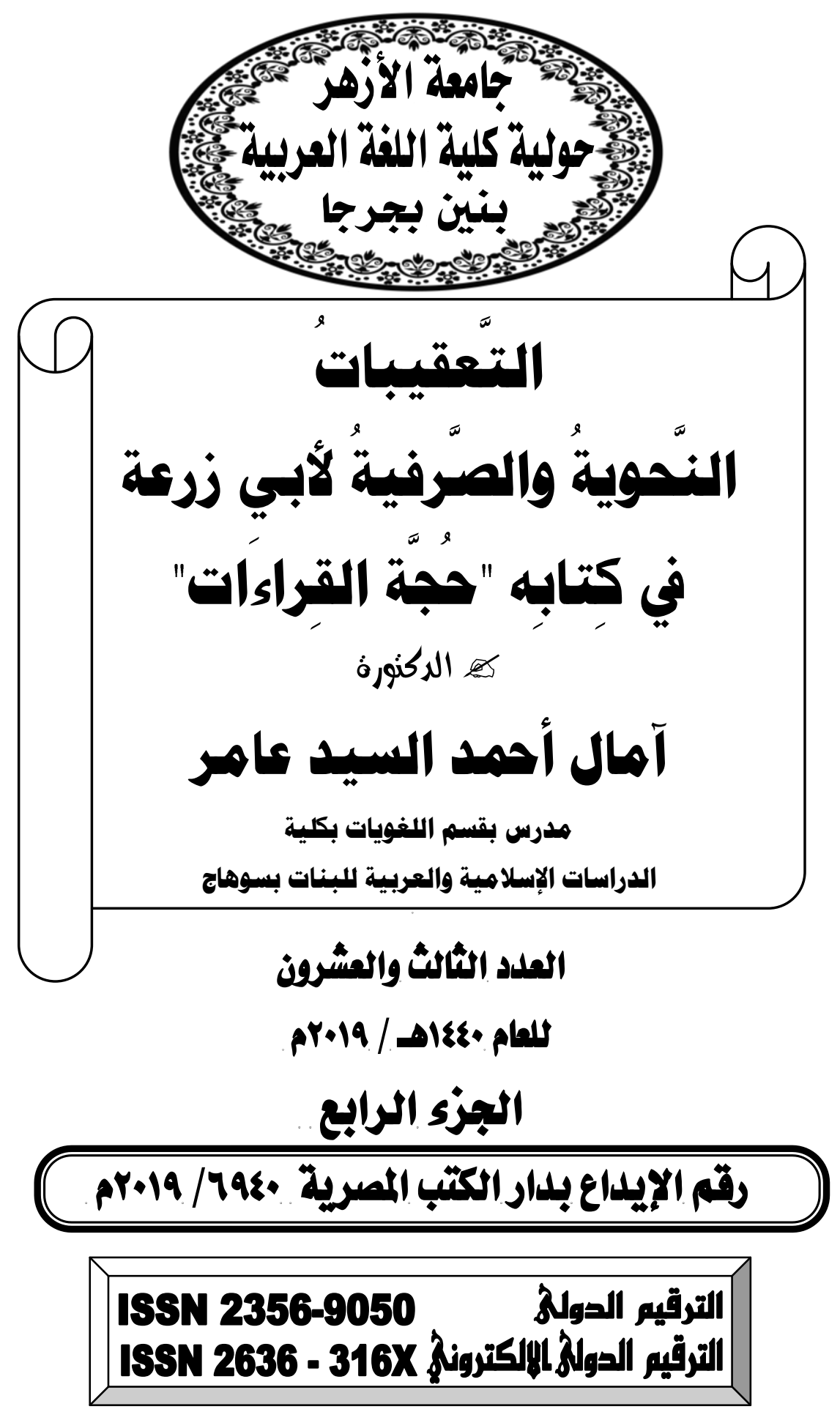




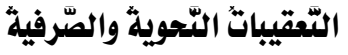
لأبي زرعة في كِتابه "حُجَّة القِراكَاتِ" (r.

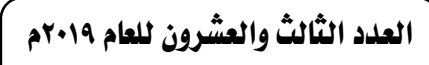

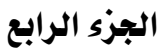

\section{هلغص البحث}

تعرضت هذه الاراسة لاستخلاص فكر أبي زرعة النحوي والصــرفي، عن طريق تتبع تعقياته المتصلة بذلكت. وكان الهُف من البحث إيراز ما بأتي :

- تعرَّض البحث لقيمة كتاب حجة القراعات ، وقيمة مؤلفــهـ ، فهـــ مؤلف في أشرف العلوم ، وهو قراعات القرآن الكريم والاحتجاج لها ، ومــن

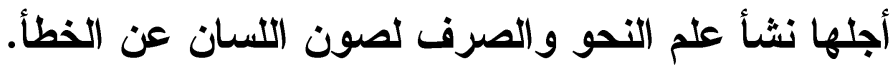
- بيَّن البحث أنَّ الكتاب يعبر عن فكر صاحبه النحوي ، فيظهـر مـن خلاله ميوله ومذهبه النحوي . - أثبت البحث أنَّ القرآن الكريم قامت على أساسه قواعد ، وبنيت على

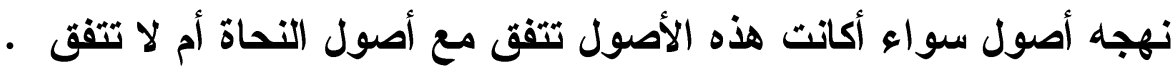
- بيَّن البحث الترابط القائم بين دراسة القراءات والاحتجاج لها ، وبين

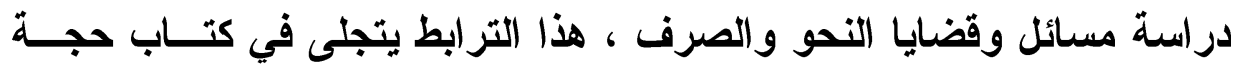

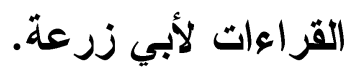

- أبرز البحث آراء النحويين وطريقة عرض أبي زرعة لهذه الآراء . - جاء البحث في مقدمة ، وتمهيد، وفصلين، وخاتمة، وفهارس للمراجع .

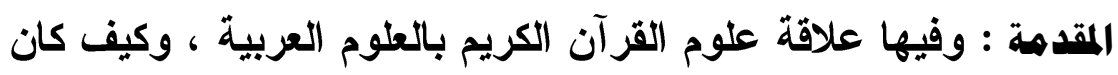
لكليهما الأثر العظيم في الآخر ؟ . التههيسد ، وعنوانه : أبو زرعة ، وفكره النحوي في ضوء تعقيباتـهـ على توجيه القراءات و يشمل مبحثين :

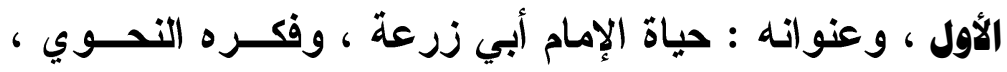
ومنهجه في تناول قضايا النحو والصرف .

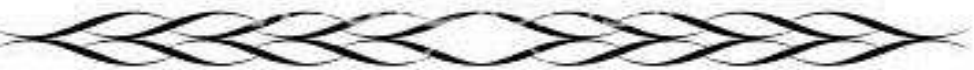




\section{الترقير الدولخ \\ ISSN 2356-9050}

المبحث الثـاني ، وعنوانه : نبذة عن علم القــــاعات ، والتــأليف فــي

- الاحتجاج

\section{الفصل الأول : تعقيبات أبي زرعة النحوية. \\ الفصل الثاني : تعقيبات أبي زرعة الصرفية.}

- خلص البحث إلى أنَّ أبا زرعة لم ينل من الشهرة ما نالهه كتابه (حجة القراعات)، ولعل ذلك لبعده عن مناطق الظهور والاخــتلاط بعليـــة القــوم ، أو حضور مجالس الحكام والولاة.

- تبيَّن من خلال البحث إتقان أبي زرعة لقضــايا النحــو والصــرف وإجادته في عرضها على الرغم من أنَّه عالم في القراعات ، وذلك رغبة رغنة منه في الإمام بعلوم العربية ؛ ليتسنى له دراسة كتاب الله وقر اعاته. - تبيَّن أن مؤلفي كتب النحو والصرف في زمانه ، أو ما بعد زمانه لم

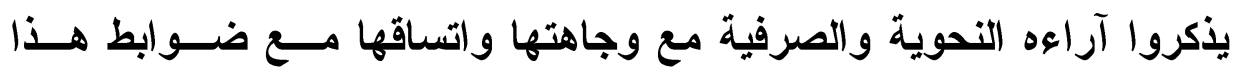

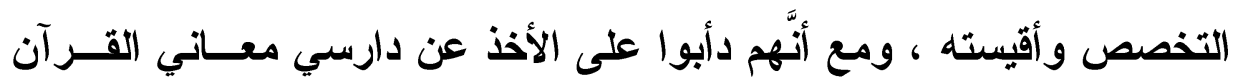
والمفسرين النحويين غيره.

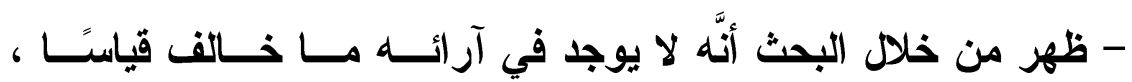

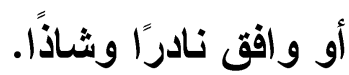
- ظهر من هذا البحث أنَّ أبا زرعة أكثــر مــن ذكــر قضـــايا النحــو والصرف من خلال التعقيبات المتعلقة بها في أغلب القراعات التــي يقتضــي فيها المقام دراسة هذه القضايا بجاتب التعقيبات الأخرى التي تتعلق بــالمعنى والالالة و التفسير و الفقه والبلاغة. 

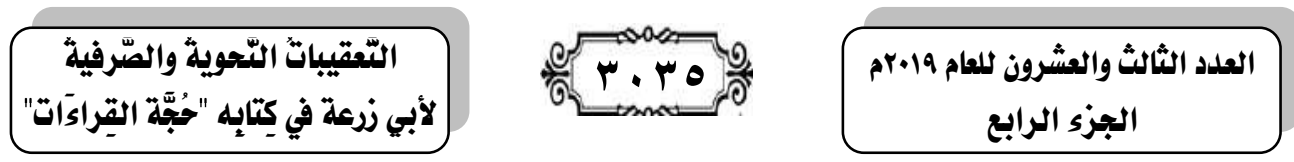

\section{$\underline{\text { Research Summary }}$}

This study was conducted in order to extract the ideas of $\mathrm{Abu}$ Zarah grammar and epistemology, by tracking his related comments.

The aim of the research was to highlight the following:

-The search for the value of the book of argument readings, and the value of the author, he is the author of Ashraf Science, a reading of the Koran and protest, and for it grew grammar and syntax to keep the tongue of error.

-The research that the book reflects the thought of the author of grammar, shows through his tendencies and grammatical doctrine.

-The research proved that the Holy Quran based on the basis of rules, and built on the approach assets whether these assets correspond to the assets of the women or not agree.

-The research between the correlation between the study of readings and protest, and the study of issues and issues of grammar and interpretation, this correlation is reflected in the book of argument readings of Abu Zarah.

-The research highlighted the views of the grammarians and the presentation of Abu Zarah to these views.

- The research came in an introduction, a preface, two chapters, a conclusion, and indexes for references.

Introduction: The relationship between the sciences of the Koran and the Arab sciences, and how they both have a great impact in the other. ?

The preface, entitled: Abu Zar'a, and his grammatical thinking in the light of his comments on the direction of readings and includes two sections:

The first topic, entitled: The life of Imam Abu Zarah, his grammatical thinking, and his method of dealing with issues of grammar and interpretation.

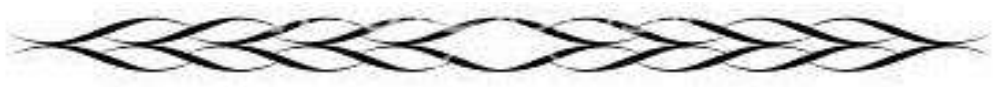




\section{الترقيم الدوله \\ ISSN 2356-9050}
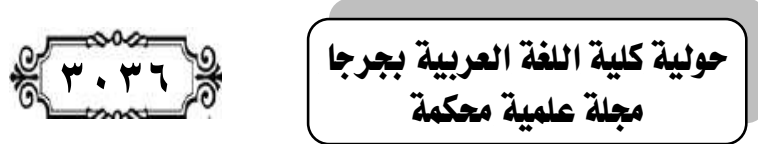

The second topic, entitled: An overview of the science of readings, and the composition of the protest.

Chapter 1: Comments of Abu Zarah grammar.

Chapter Two: Comments of Abu Zarah Al - Sharifi.

-The research concluded that Abu Zar'a did not gain fame from what he received his book (argument of readings), and perhaps this distance from the areas of emergence and mixing Baalip folk،

Or the presence of boards of governors and governors.

-Through the research, the mastery of Abu Zera'a for the issues of grammar and morphology and his presentation in his presentation, although he is a scholar in the readings, was revealed in order to study the book of God and his readings.

-It was found that the authors of books of grammar and interpretation in his time, or beyond his time did not mention his grammatical and grammatical views with their correctness and consistency with the disciplines of this specialization and set it down, although they have always taken the scholars of the Koran and other grammatical interpreters.

-It emerged through the research that there is nothing in his views contrary to the measurement。

Or rarely approved as CHA.

-It emerged from this research that Abu Zerah more than mentioned the issues of grammar and interpretation through the comments related to most of the readings in which the need to study these cases as well as other comments that relate to the meaning and significance, interpretation, jurisprudence and eloquence. 


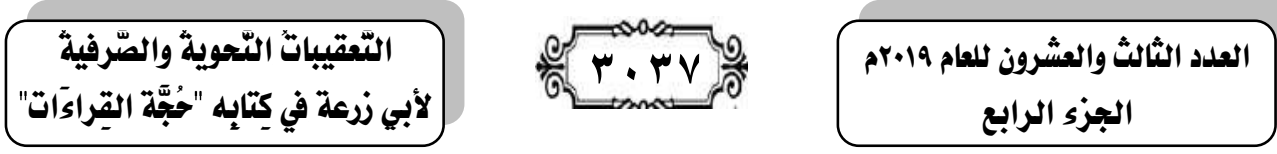

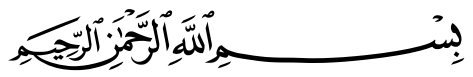

\section{الاقدهمة}

الحمدُ لله مُنزّل القرآن بلسان عربي مبين ، والصدلاة والسلام على خير

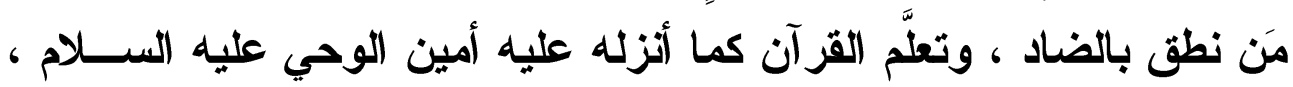
صلاة وسلامًاً دائمين متلازمين إلى أن يرث الله الأرض ومَن عليها.

وبعد :

فارتباط علوم العربية بعلوم القرآن لازم ، والتأليف فيها قائم ، والغاية من دراستهما جليلة ، والبحث فيها ذو فو ائد عظيمة.

فَخِدمة القرآن الكريم من أعظم وأجل الغايات التـي ســـى لهـــا الثــيوخ و التحلاميذ على مرِّ العصور، ولا سيِّما عصور التأليف الزَّاهية في الحضــارة الإسلامية.

ومن بين علوم القرآن علم عظيم اثتثهر ونبه فيه علماء عظام ، هذا العلم هو : علم القزاعات وجمعها وإظهار حجج اختيارها. ومن بين هؤلاء العلماء الأين كتبوا في حجج اختيار القراعات الإمام

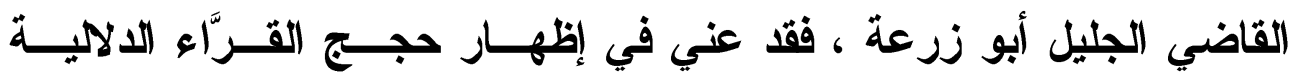
المعنوية ، والتفسيرية ، والفقهية ، والنحوية ، والصرفية ، فــن يطـالع كتابه : (حجة القراعات) يجده غني بقضايا النحو ، والصرف المتنوعة. وقد كان علماء النحو في مقابل ذللك يوثقون مؤلفــاتهم ، ويحتجــون لتقوية آرائهم بقراعات القرآن الكريم. 


\section{الترقير الدولخ}

ISSN 2356-9050
क.
حولية كلية اللفة العربية بجرجا

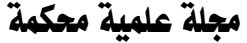

ومن هنا نلحظ الترابط و التبادل فيما يخدم القرآن الكريم كما يخدم لغته (اللغة العربية) ، كما كان لهذا الترابط والامتزاج بين هذه العلوم الثـــريفة

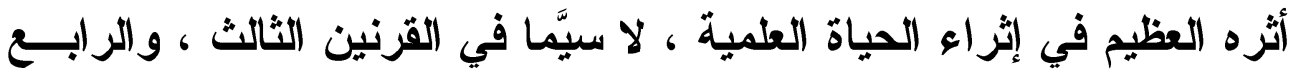
الهجريين الذين عاش فيهما إمامنا أبو زرعة.

فقد انفسحت أمام علماء هذين القرنين مجــالات البحــث ، وتنوعـــ

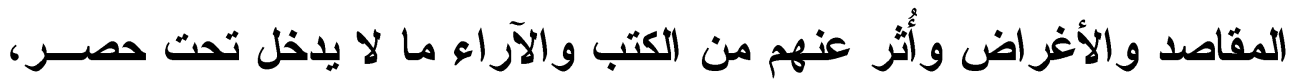

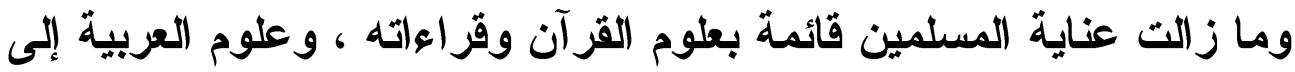
اليوم تصنيفًا وتدريسًا. ولا أبالغ إن قلت : إن العلماء إنَّما قصدوا إلى دراسة لغة العرب مسن

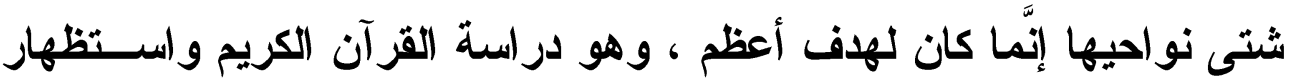

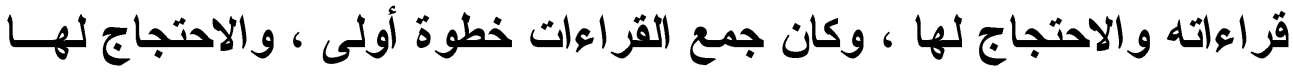

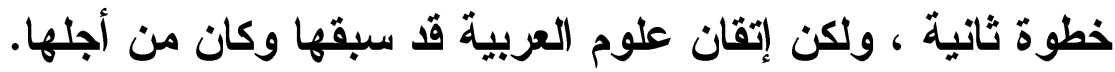
وقد اخترت من بين كتب الاحتجاج للقراعات كتابًا قيم النفــع شــريف المقصد والهاف ، وهو كتاب : "حجة القراءات" لأبي زرعة ، وعلى الــرغم

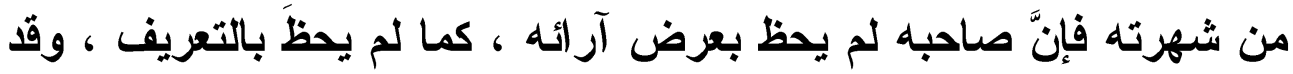

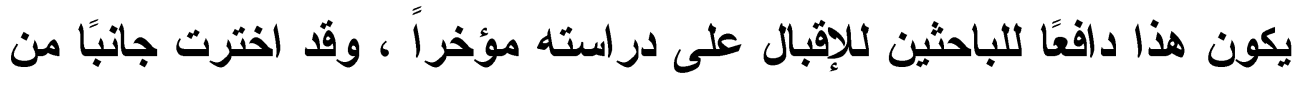
محتوى هذا الكتاب ، هذا الجاتب يتصل بمجال تخصصي النحو والصــرف ،

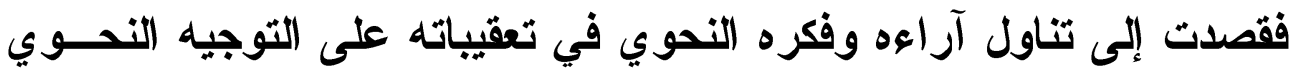

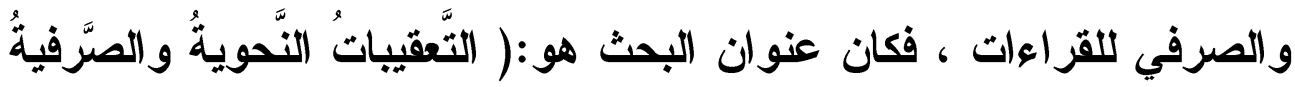

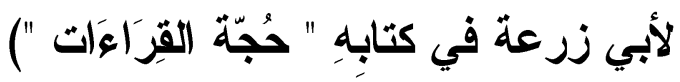




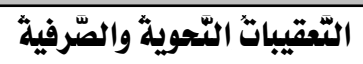

لأبي زرعة في كِتابهه "حُجَّة القِراكَاتِ"
P.

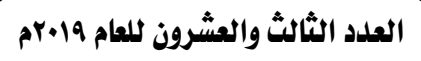

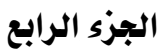

\section{وكاتت الأسباب التي دفعتي لاختبار هذا الموضوع تتلخص فيما بلي:}

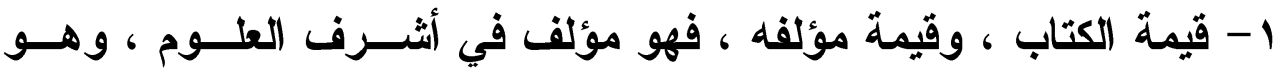

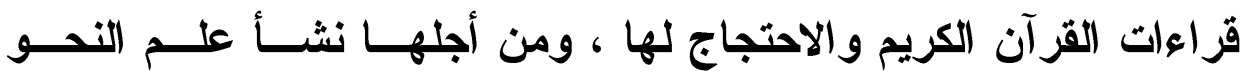
والصرف لصون اللسان عن الخطأ.

r- الكتاب يعبر عن فكر صاحبه النحوي ، فيظهر من خلاله ميوله ومذهبه

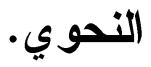

r- أنَّ القرآن الكريم قامت على أساسه قو اعد ، وينيت على نهجه أصــول سواء أكاتت هذه الأصول تتفق مع أصول النحاة أم لا تتفق فأردت إظهار ذلك.

ع - التزابط القائم بين دراسة القراءات والاحتجاج لها ، وبين دراسة مسائل

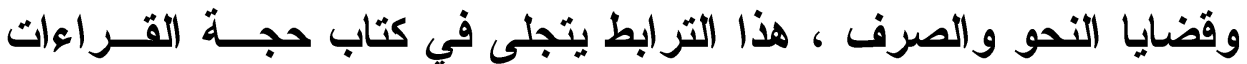
لأبي زرعة.

ه- أردت إبراز آرائه النحوية التي لم أجد من بين النحويين من ألمح لها ، أو عرضها في مؤلفاته مع كثرتها حتى معاصريه ، أو من جاء بعده. צ - قد يكون في دراسة جاتب من هذا الكتاب تعويض لصاحبه عما لدق به من إغفال كتب التزاجم للتعريف به ، وقد يكون في دراسة آرائه النحوية

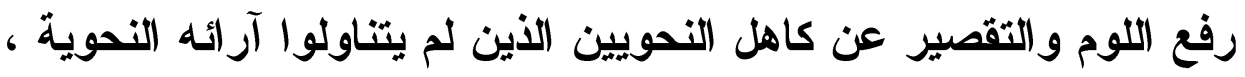

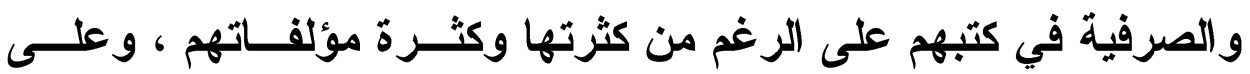

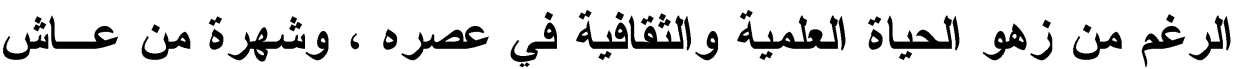
فيه من علمائنا - رحمهم الله - - منو

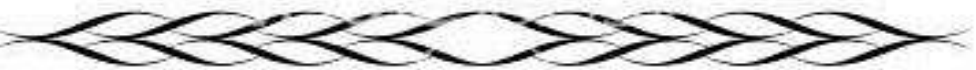




\section{الترقيم الدولم ISSN 2356-9050}

o.

حولية كلية اللفة العربية بجرجا مجية مجلة علمية محكمة

\section{وقد جاعت خطتي في البحث شاملة ما بأتي :}

مقدمة ، وتمهيد ، وفصلين ، وخاتمة ، وفهارس للمراجع • أمَّا الإقدهة : فقد تحدثت فيها عن علاقة علوم القرآن الكريم بــالعلوم

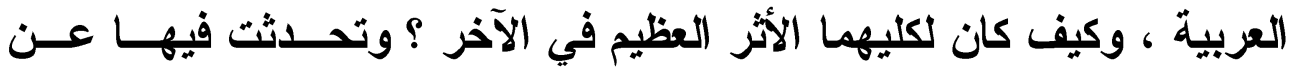
دوافع اختيار هذا الموضوع •

التمهيد ، وعنوانه : أبو زرعة ، وفكره النحوي في ضوء تعقيباته علــى توجيه القزاعات

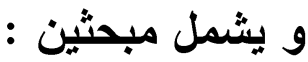

المبحث الأول ، وعنوانه : حياة الإمام أبــي زرعــة ، وفكـره النحــوي ، ومنهجه في تناول قضايا النحو والصرف .

الإبــث الثـانتي ، وعنوانه : نبذة عن عنــم القــر اعات ، والتــأليف فـي - 1احتجاج

ـ الفصل الأول : تعقيبات أبي زرعة النحوية. ـ الفصل الثاني : تعقيبات أبي زرعة الصرفية. ـ الغاتمة : ذكرت فيها أهم نتائج البحث والار اسة.

$$
\text { (وما توفيقي إلَّا بالله عليه توكلت و إليه أنيب). }
$$




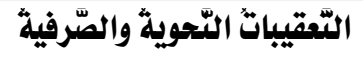
لأبي زرعة في كِتابه "حُجَّة القِراءَاتَ" $\frac{0}{4 \cdot 21}$

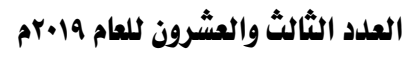
الجزء الرابع

أبو زرعة ، وفكره النحوي في ضوء تعقيباته على توجيه القراءات

ويشمل مبحثين :

\section{المبحث الأول}

حياة الإهام أبي زرعة ، وجهوده ،

وهنهجه في تناول قضايا النحو والصرف

وفيه أتناول الآتي :

$$
\text { نسبه - وهوألفاته - وشيوخه - وتلاهيذه - وعصره. }
$$

وفي البداية تجدر الإثشارة إلى أمر غاية في الأهمية لايَّ ، فإنَّ أبسـط

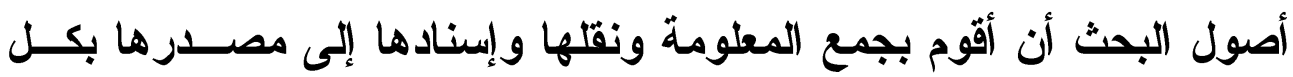
أمانة ودقة ، وهذا ما ألزمت به نفسي في كل مواضع البع البحث.

ولكن حين أقدمت على التعريف بحياة العالم الجليل الإمام أبي زرعــة

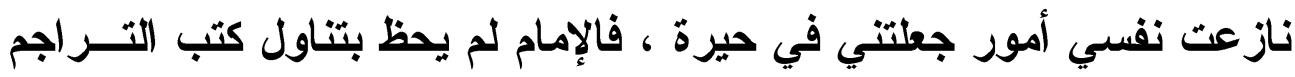

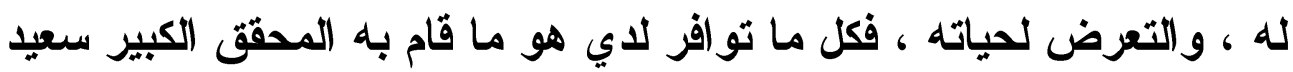

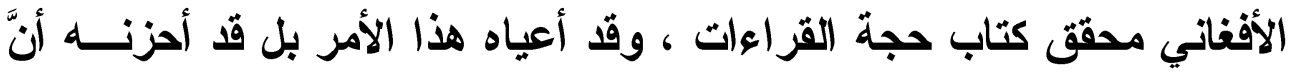
كتب التراجم مع كثرتها لم تترجم لأبي زرعة هئ. وقد أعياني ما أعياه ، وأعياني بالإضافة إلى ذلك أنَّ الأمانة تقتضــي أن أقوم بالبحث عن ترجمته ماعيان 


\section{الترقيم الدولم}

ISSN 2356-9050
Q.
حولية كلية اللفة العربية بجرجا مجلة علمية محكمة

ولذا فإنَّني سأعتمد في تناولي شخصية أبي زرعة على مـا تحصـل

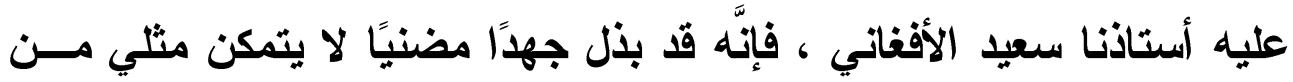

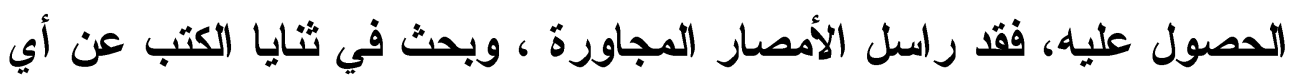

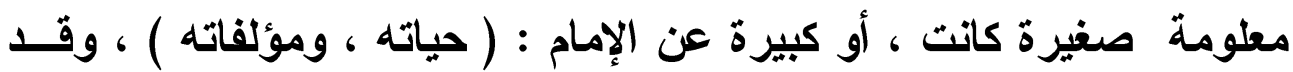

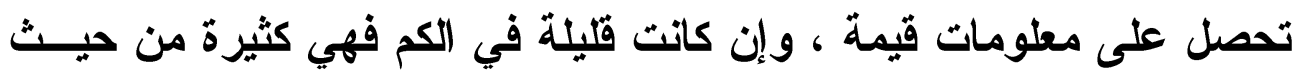
الكيف و النفع.

ولكني حاولت ولم أدخر جهذًا - وإن كان متواضعًا- أن أرجع إلى ما

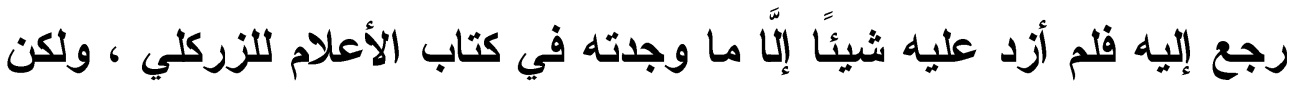

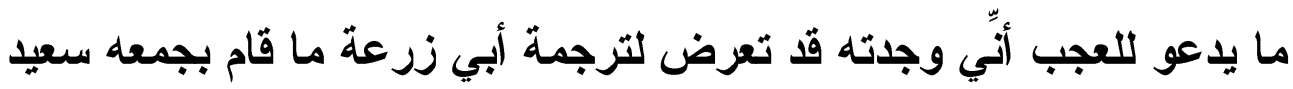
الأفغاني وأحالني إليه و إلى صفحات من مقدمة المحقى. ولذا أرجو من القارئ قبول العذر عن عدم التحصل على معلومات غير

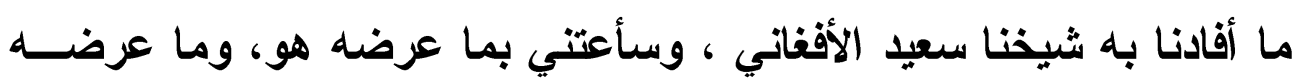
أيضًا الزركلي في الأعلام .

وأبدأ بنسبه ، فهو : عبد الرحمن بن محمد بن زنجلة المكنى بـأبي زرعــة قاريء قاضي مالكي المذهب.

عاش في القرن الرابع الهجري ، قرأ عليه وأملاه الإمام : أحمــــــن

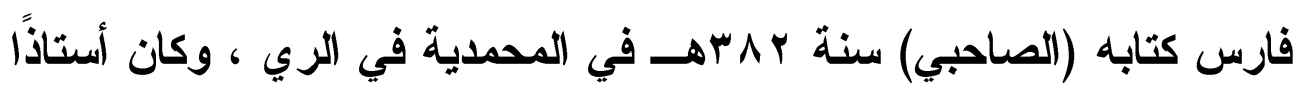

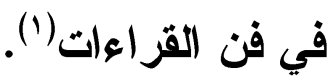

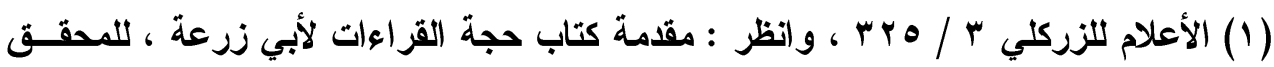

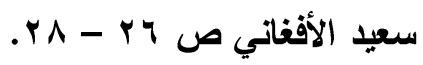

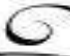



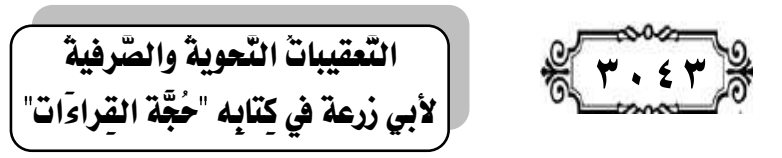

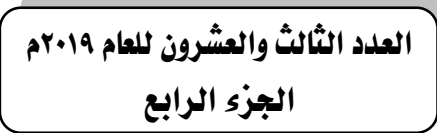

وقا فضلَّه سعيد الأفغاني على شيخه أحمد بن فارس ، فقـــال : " ولا

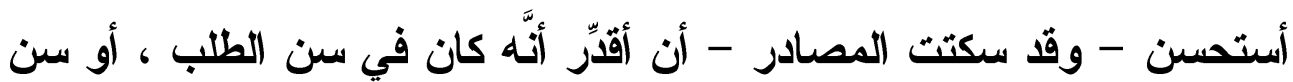

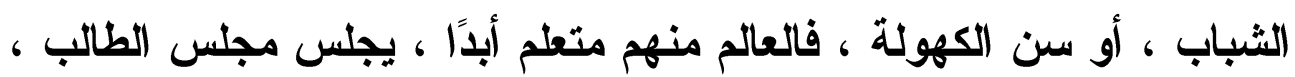

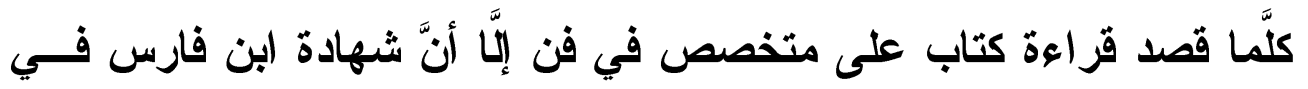

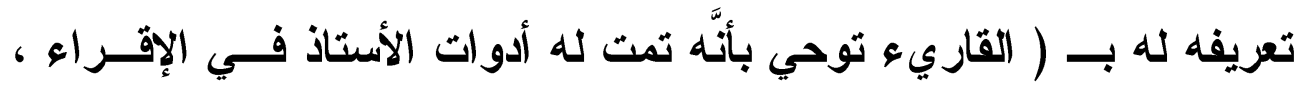

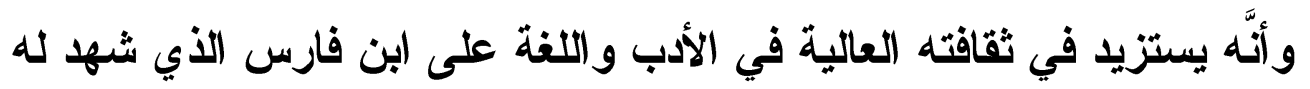

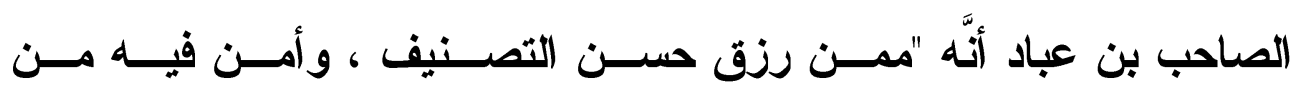
(التصحيف") (')

وهكذا أجد سعيد الأفغاني يستنبط من كلام الصاحب وثناءه على أحمد

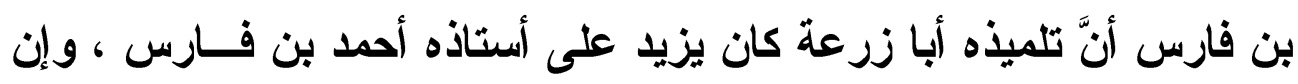

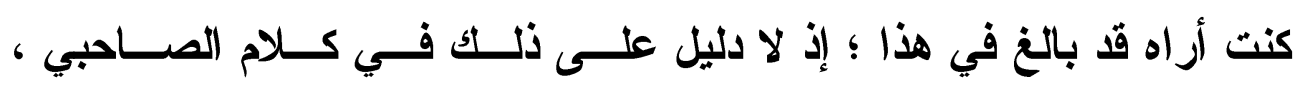

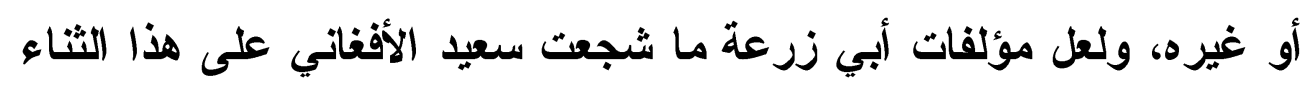

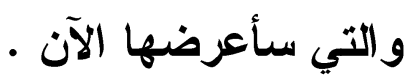

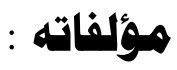

ما زلت أتلمس خطا المحقق الكبير سعيد الأفغاني دون مقــدرة منــي

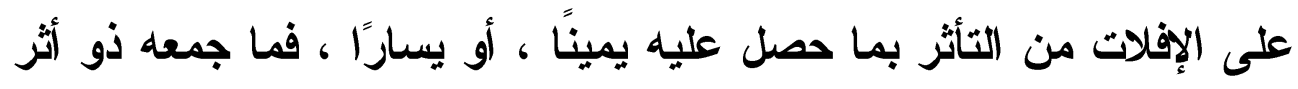

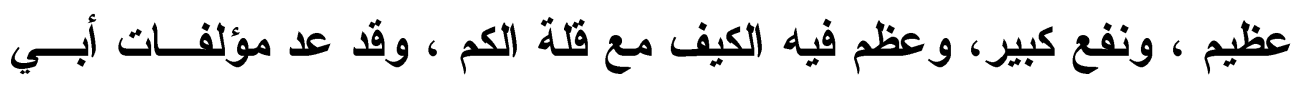

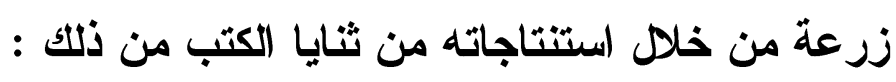

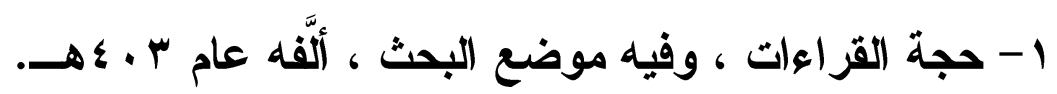

(1) مقدمة كتاب حجة القراءات ، للمحقق سعيد الأفغاني ص 4 ب. 


\section{الترقير الدولخ}

ISSN 2356-9050

ץ- كتاب التفسير ، ورَدَ ذكره في حجة القراءات(1).

r- شرف القزاءات في الوقف والابتداء ، وهو يقع في جزأين مخطوط في خزانة عاكف العاني ببغداد (؟)

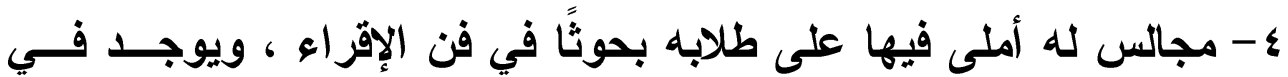
كتاب سعد السعود بعضًا منهاب(ّ).

شيموخه ، وتلامهيذه :

أولاًا : شيـوخه :

ما علم بالتأكيا والتصريح من المحقق أنَّ له شيخًا مشهورًا هو : أحمد

بن فارس صاحب كتاب (الصاحبي) ويجدر بي هنا أن أعرف له في إيجاز.

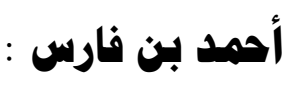

هو أبو الحسين أحمد بن فارس بن زكريا بن محمد بن حبيب الرازي ،

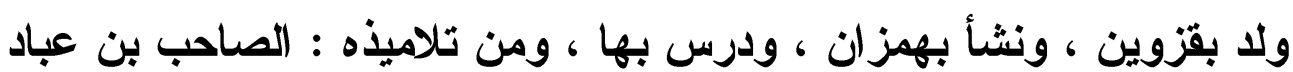
، ومن أساتذته وشيوخه : أبو بكر أحمد بن الحسن الخطيب راوية ثُطـبـ ، وأبو الحسن علي بن إبراهيم القطان ، وأبو عبد الله أحمد بن طاهر المنجم ، وعلومه كاتت متنوعة وشاملة لا سيما اللغة التي أتقنها ، وأكثر من التأليف في فروعها المختلفة ، وكان فقيهًا شافعيًا ويناصر مذهب مالكا. أمَّا طريقة أحمد بن فارس في النحو فهي طريقة الكوفيين.

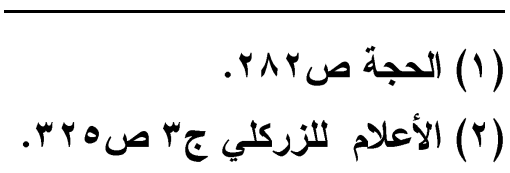

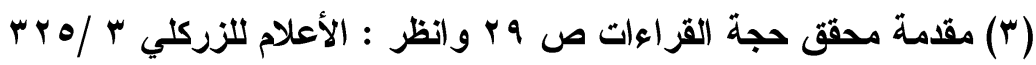




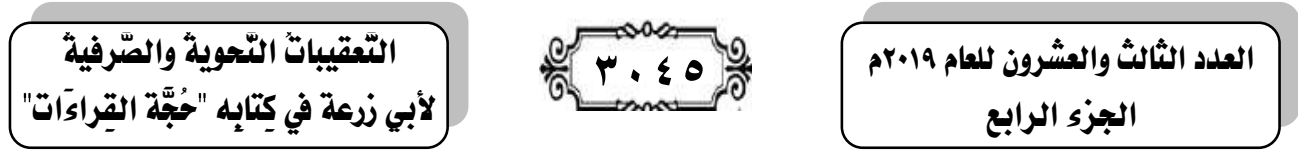

ومن مؤلفاته : الصاحبي في فقه اللغة العربية ومسائلها وسنن العرب

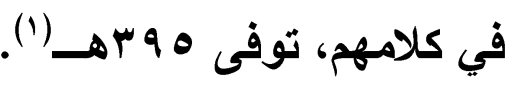

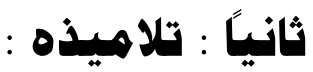

أمَّا تلاميذه فلم أجد من أورد لهم ذكرًا لا في تحقيق الكتــاب لســيد

الأفغاني ولا في الأعلام ، ولا صرح بهم في موضع آخر.

ولذا رأيت ولعلي أكون قد أصبت أن أقوم بالتعريف لمعاصريه ففي التعــرف عليهم، وعلى مكاتتهم ، ومؤلقاتهم ما قد يصل بالقارئ إلى تصور ما كــان لأبي زرعة من مكانة تماثلهم ، والله أعلم .

\section{أهم هماصربه :

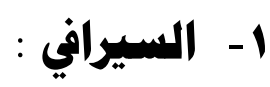

هو : أبو سعيد الحسن بن عبد الله بن المرزبان ، ولا بسيراف سنة ، ^rهـ ، خرج إلى عمان ، وتفقه على شيوخها ، ثم تحول إلى بغداد ، ودرس اللغة

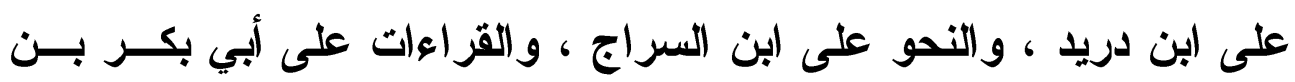
مجاهد ، من مؤلفاته : شرح كتاب سيبويه ، رد فيه علــى مخالقيــه مــن البصريين والكوفيين ، وشرح شواهد سيبويه ، والمــدخل إلــى الكتــاب ،

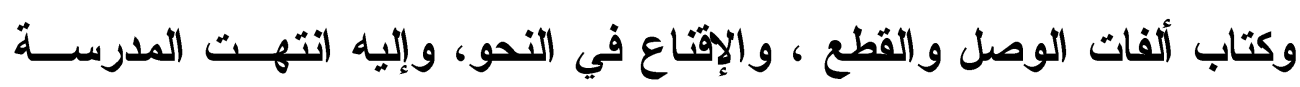

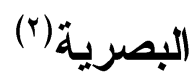

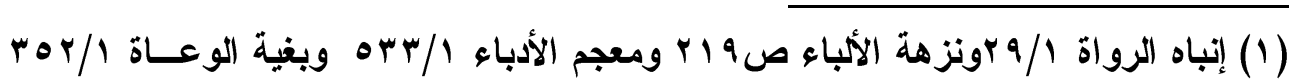

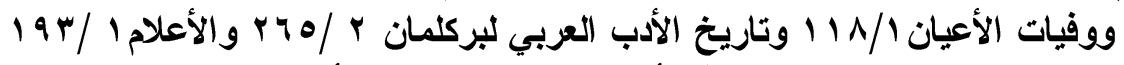

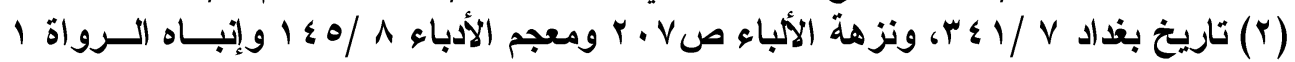

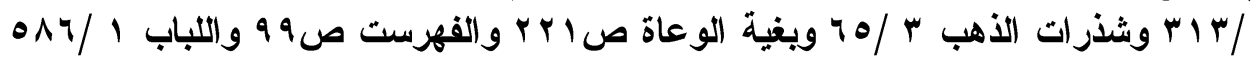

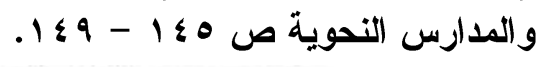




\section{الترقير الدوله \\ ISSN 2356-9050}

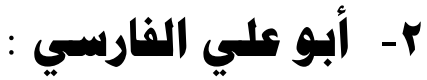

هو : أبو علي الحسن بن عبد الغفار، أحد الأيمة في علم العربية ، ولد

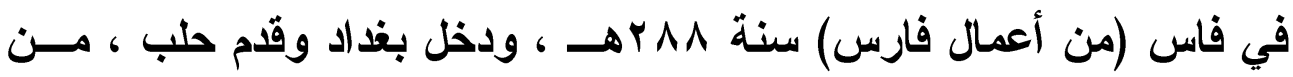
مؤلفاته : الحجة في القزاءات العبع ، والإيضاح ، والتذكرة ، والإغة فــال ، و البغداديات... وغير ذلك.

عكف على حلقات البصريين ، وحلقات البغاديين ، وحلقة أبي بكر بن

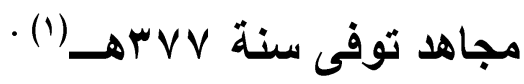
وكان ينتخب لنفسه من الآراء البصرية كما ينتخب لنفسه أيضًَـا مـن الآراء الكوفية ما صع في قياسه.

وكتابه الحجة كان يحتج فيه لكل قر اعة من تلك القزاعات مسن اللغــة و الثعر متأثرًا بآراء النحاة البصريين والكوفيين منتصرًا تارة للأولين وتارة

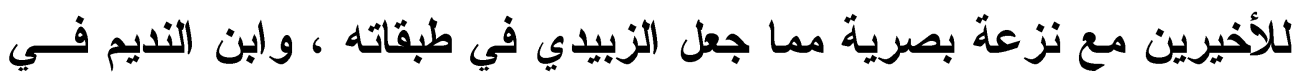

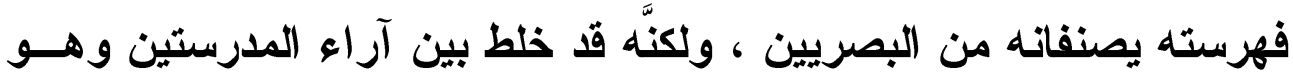
بذلك بغدادي ينتخب من المدرستين (ץ).

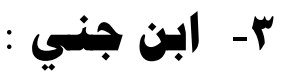

هو : أبو الفتح عثمان بن جني عالم بالنحو ، والأدب ، و التصـريف ،

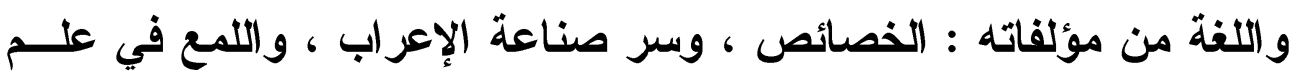

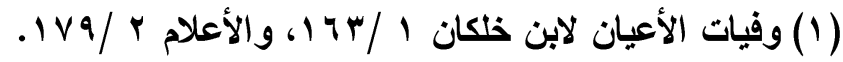

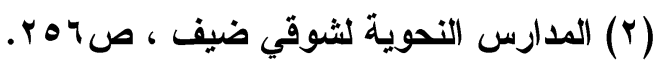




\section{التّقيباتُ التّحوية والصّرفية لأبي زرعة في كتّابه "حُجَّة القِراكَاتَ"}

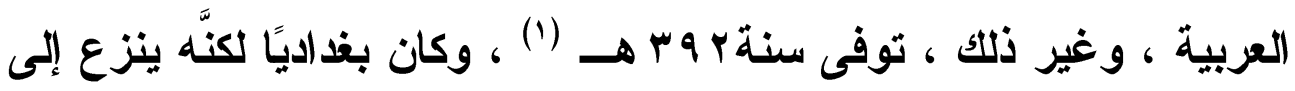

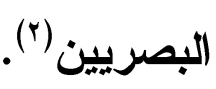

وبعد ذكر بعض معاصريه أسنطيع أن أستنتج أنَّ النهج البغدادي ، كان

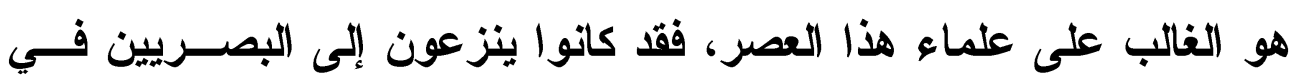

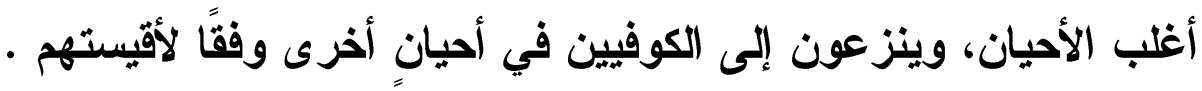

عصره :

\section{أولاً : الهياة العلمية والثقافية .}

عاش الإمام أبو زرعة بين القرنين الثالث والرابع الهجريين ، وهذان

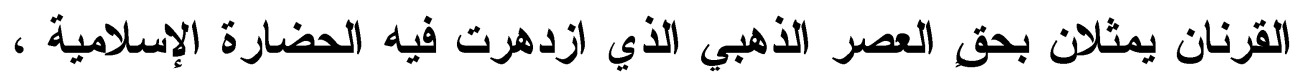
ونمت ويلغت غايتها من الاتتاج الواسع في شنى ميادين العلوم والآداب(؟).

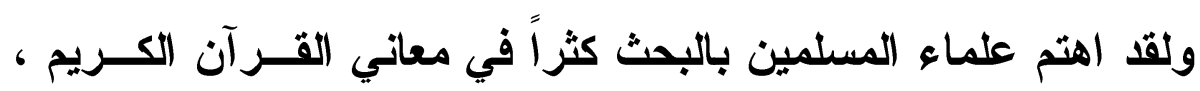

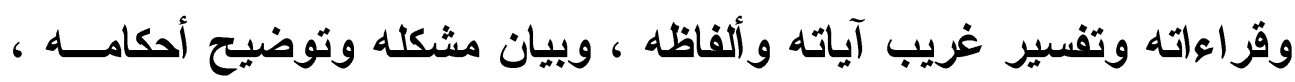

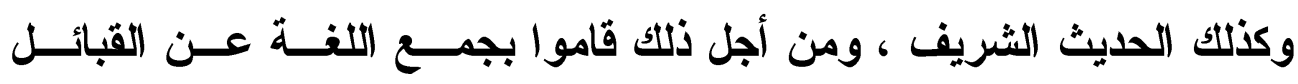
العربية الفصيحة ، فظهرت الاراسات اللغوية وتطورت.

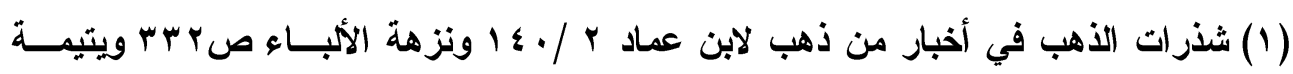

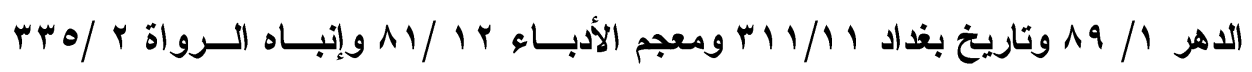

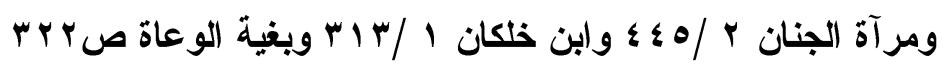

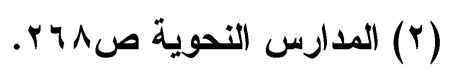

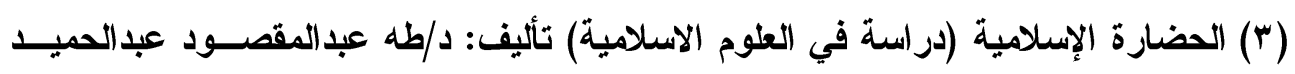

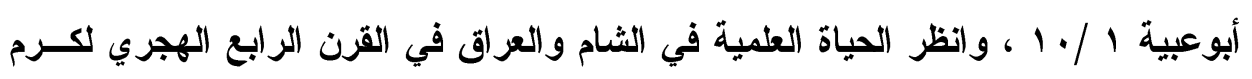

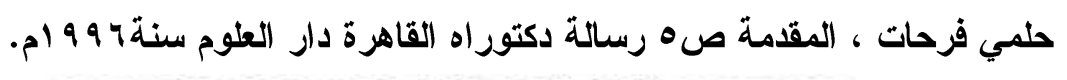




\section{الترقيم الدولخ}

ISSN 2356-9050 r. $2 \Lambda$
حولية كلية اللفة العربية بجرجا

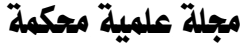

وكان من أوائل المهتمين بذلك العلماء الذين استقروا في البصرة أول

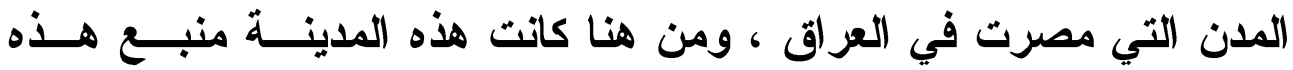

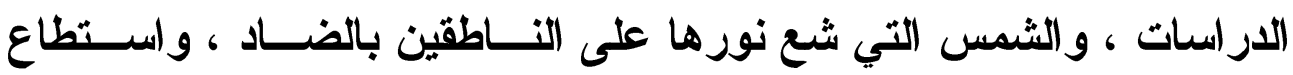

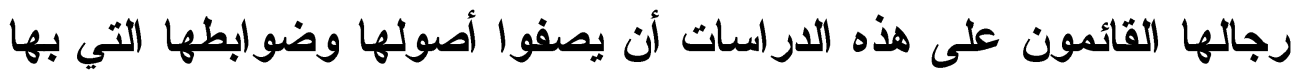
يستطيعون أن يفسروا آيات كتاب الله ، وأحاديث رسول الله- صلى الله عليه

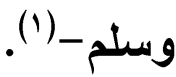

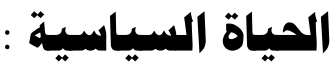

من الناحية السياسية كان عصر أبي زرعــة عصــر ضــف الدوبــة العباسية ، فالخلفاء مغلوبون على أمرهم ، والأمر لغيـــهم وولاة الأقــاليم وعمالهم مستبدون بمعظمها.

فمصر في أيدي الفاطميين ، ثم في أيدي الإخشيديين ، وولايات فارس يتداولها المتظلبون ، و الموصل بين الحمدانيين وآل بويه ، وحلـب وبــلاد

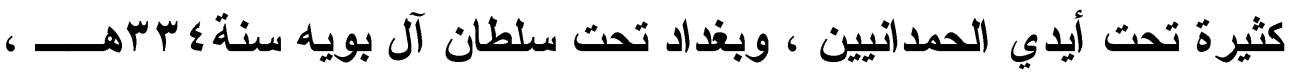
ولقد تعرض هؤلاء للخلفاء بالخلع والإذلال ولم يكن للخليفة إلَّا الاسم (ץ). هذهبيه النحوي:

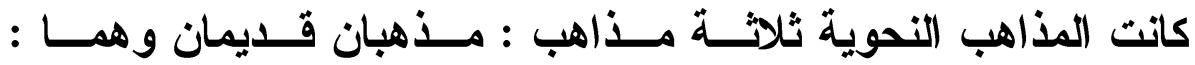
البصري، والكوفي ، ومذهب حدث من خلط المذهبين والتمييز بينهما وهو :

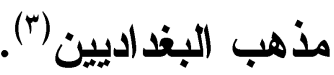

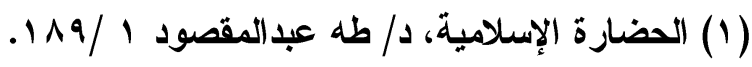

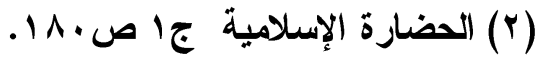

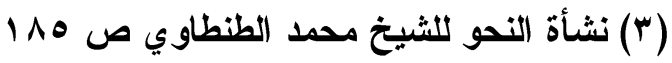



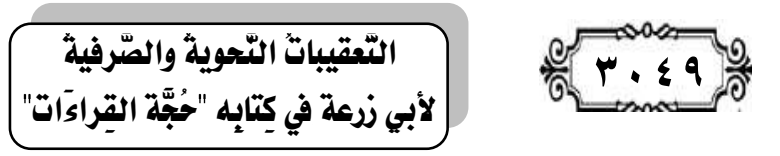

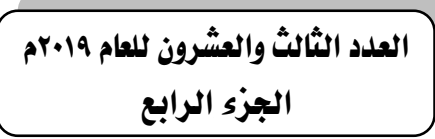

وقد لاحظت من خلال فكر معاصري الإمام أبي زرعــة أنَّهـم كــانوا

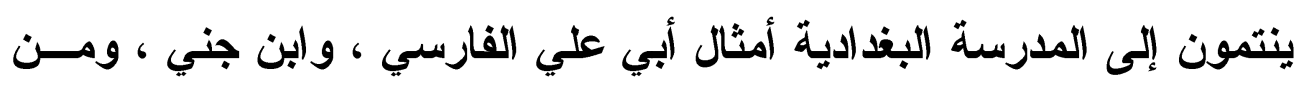

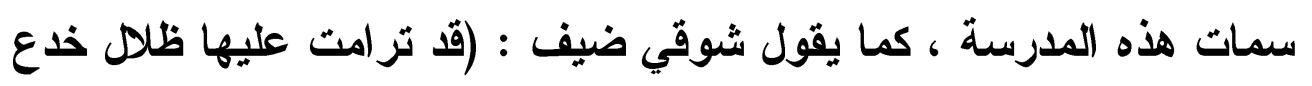

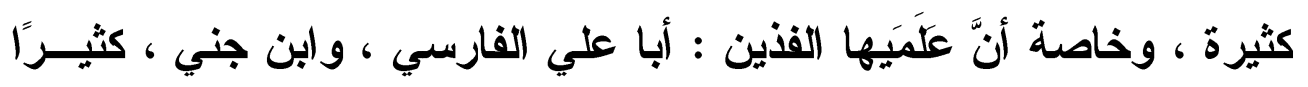

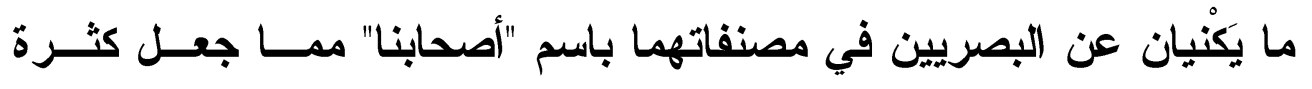

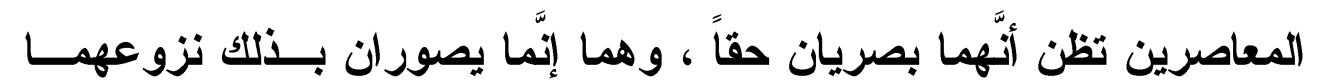

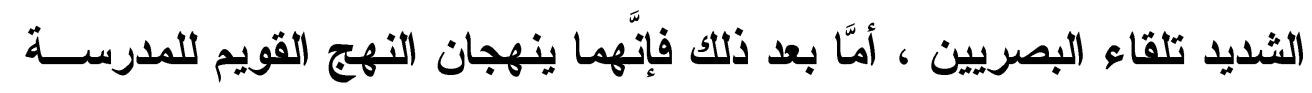
البذادية القائم على الاتخاب من آراء المدرستين البصرية والكوفية) (1).

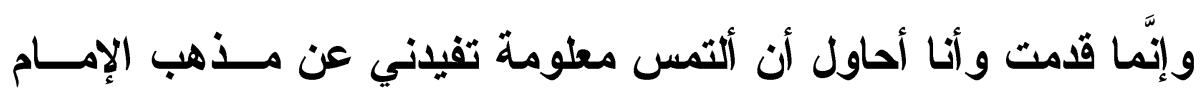

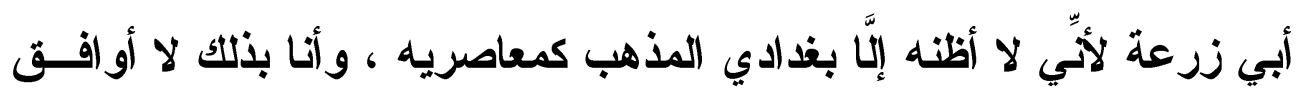

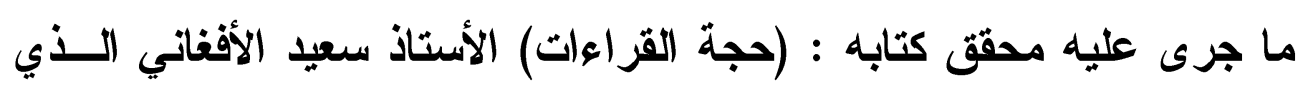

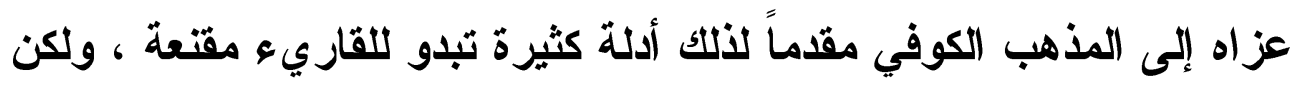

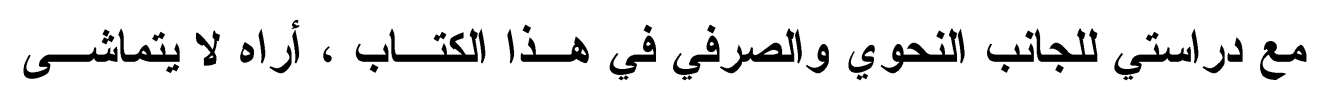

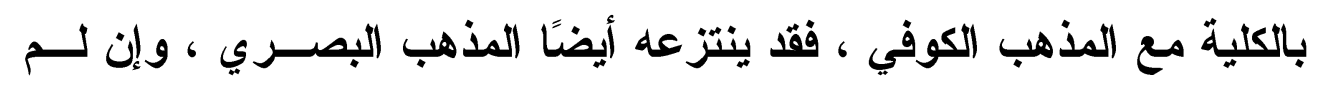

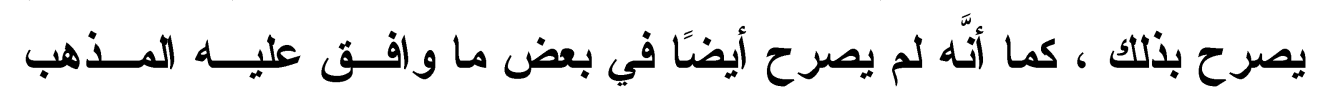
الكوفي بتأييده لهم.

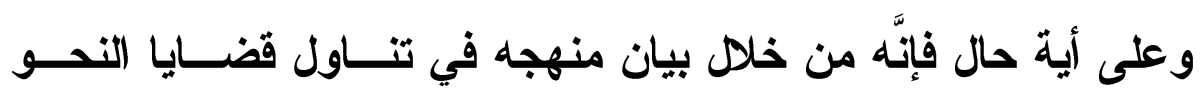

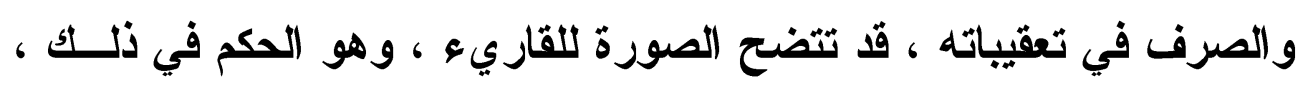
والله أعلم.

(1) المدارس النحوية لثوقي ضيف صل،،V. 


\section{الترقيم الدولم ISSN 2356-9050}

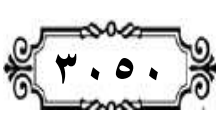

حولية كلية اللفة العربية بجرجا مجلة علمية محكمة

\section{هنهجه في تناول تضايا النحو والصرف :}

من هذا المنهج يستطيع القارئ استخلاص فكره النحوي واستظهاره بجلاء . وبداية أريد أن أؤكد هنا إلى ما سبق وأن أثشرت إليه من قبل أنَّه مـــا

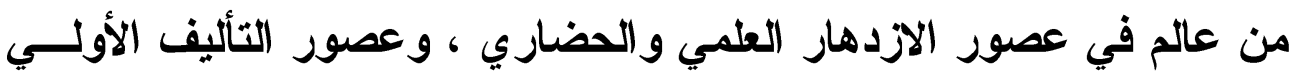

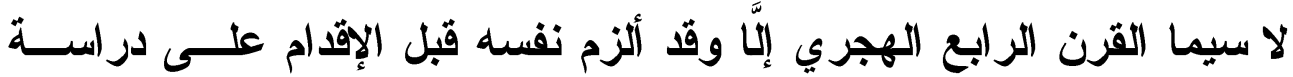

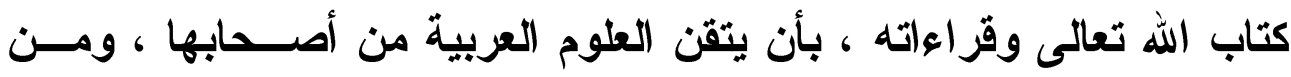

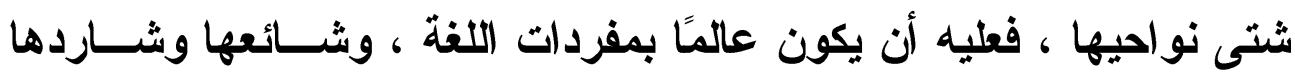

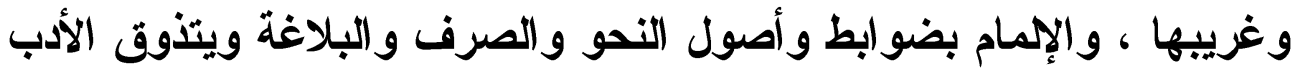

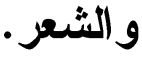

وهذا ما انتهجه علماء العصر الذي عاش فيه إمامنا ، ولم يخرج هـو

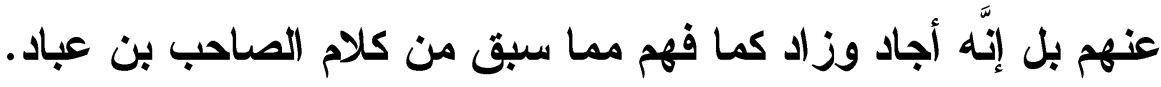
فقد كان عالمًا بالقراعات ، وهذا كاف لأن أحكم بعلمه في النحو والصرف. ومع هذا ألحظ أمرين بدعوان للأسف :

الأهر الأول : أنَّهَ لم يؤلف كتابًا في النحو و الصرف مع إتقانه كما نرى فيما بعد - ب ب

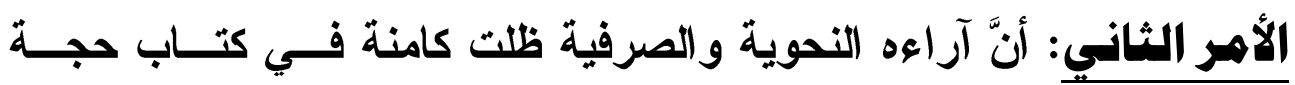

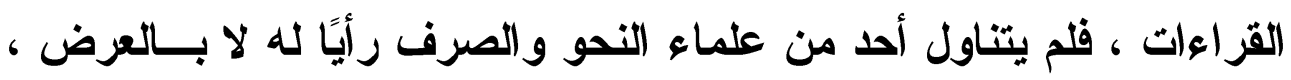

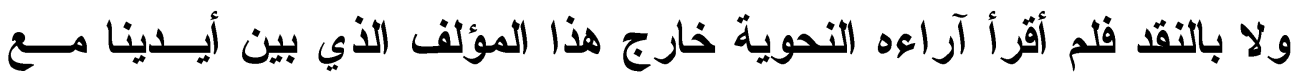
كونه انفرد بيعض الآراء في وجهة نظري. 

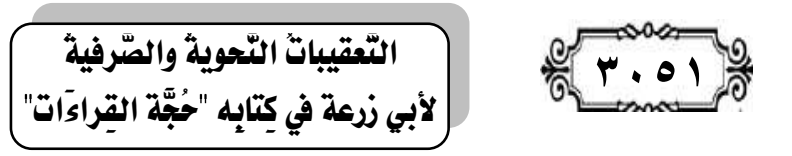

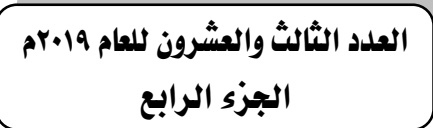

ولعل هذين الأمرين كانا دافعين لعدم إطلاق لقب القارئ النحوي علــى

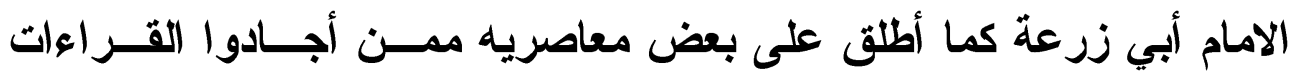

و النحو.

همادره :

إنَّ مصادر أبي زرعة متعددة ، ولكنَّها خفية ؛ لأنَّهَ يظلب عليـهـ عــدم

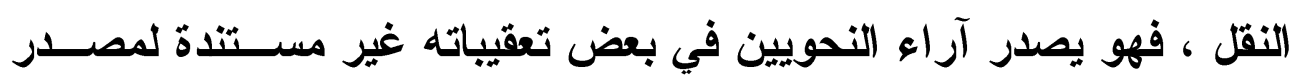

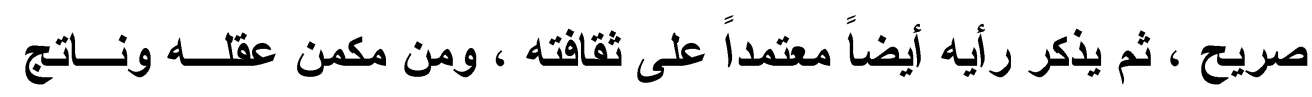
تعليمه .

وأصل هنا إلى بيان فكره ومذهبه النحوي ، فهو من الناحية الثــكلية المنمثلة في استخدامه لمصطلحات النحويين ، كان يستخدم من المصطلحات

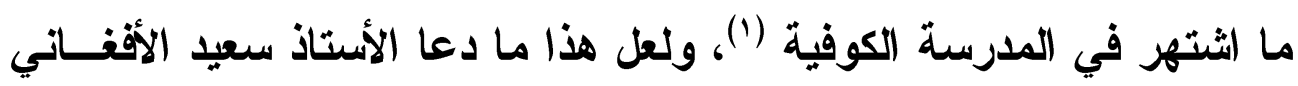

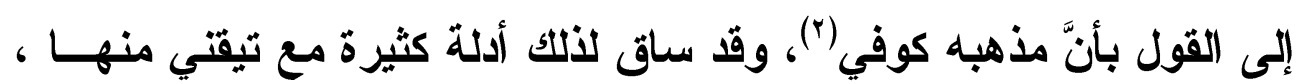

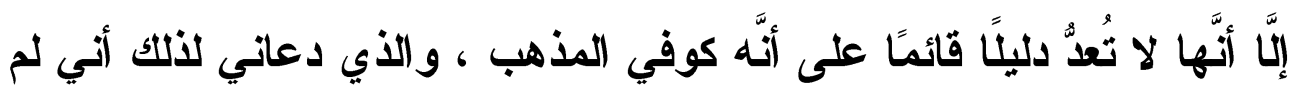

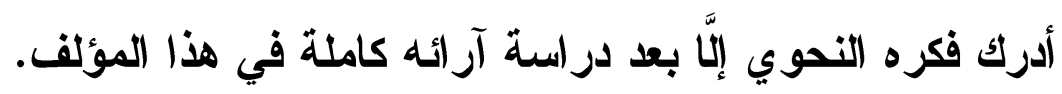

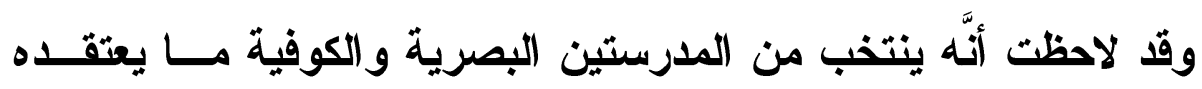

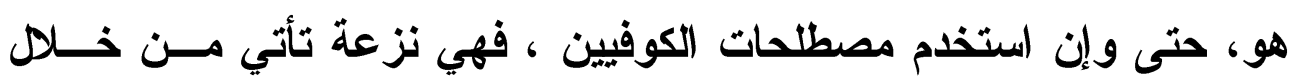

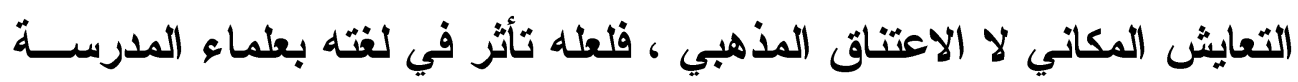

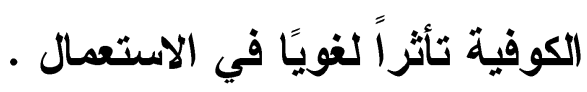

(1) المدارس النحوية لثوقي ضيف ص 170

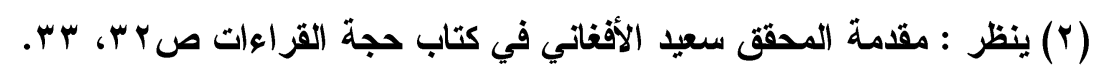




\section{الترقير الدولخ}

ISSN 2356-9050 r.or

وأرى أتَّهَ يعد من أثباع المدرسة البغدادية ، والتــي ســبق أن بينـــ

سماتها العامة ، كما كان ذلك حال الفارسي ، وابن جني.

وأسوق هنا بعض المصطلحات التي لاحظتها أثناء دراستي لآرائه وهي :

قوله في باب التقاء الههزتين : (باب الهمزتين تلتثيان مسن كلمتـين

وهما مختلفتا الإعر اب)(")

كذلك تسميته للحركات : الفتحة والضمة و الكسرة والسكون والنصــب

و الضم والجر والجزم فيقول في قراعة : (نكفِّ) (ז) ، قال : (برفــع الـــراء) يقصد بضم الراء ، وعده سعيد الأفغاني من الخلط بين ما نســيه حركـات

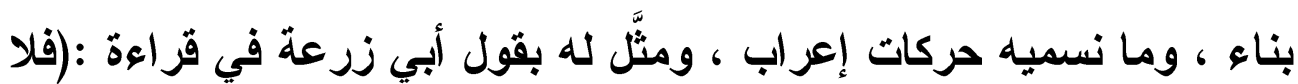

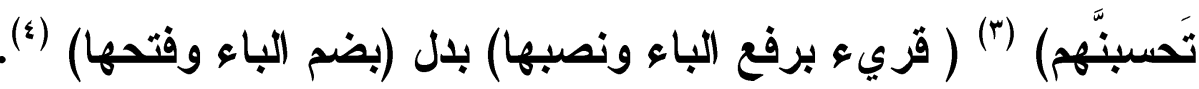
وغير ذلك مما يدل على استعماله لمصطلحات الكوفيين.

أمَّا منهجه في تعقيباته النحوية والصرفية فقد كان الإمام أبو زرعــة

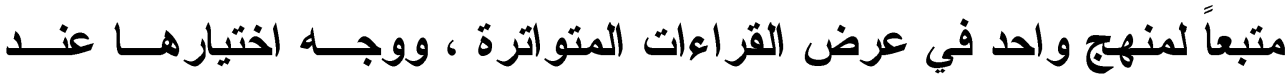
قارئيها ، وقد كان هذا عامَّاً في كل القزاعات مهما اختلفت أوجـــه التــرجيح للقزاعات ، دلالية ، أو صرفية ، أو نحوية ، أو تفسيرية ، أو فقهية.

فقد كان يعرض القراعة مسندة لصاحبها ، ثم يذكر الحجة التي ترجح

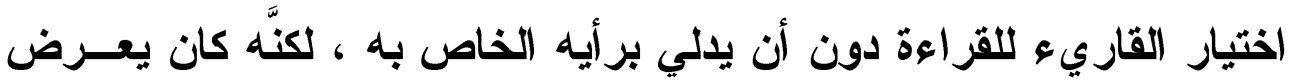

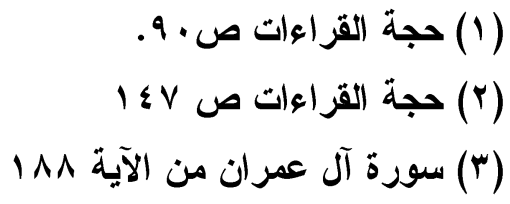

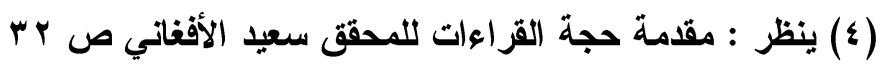




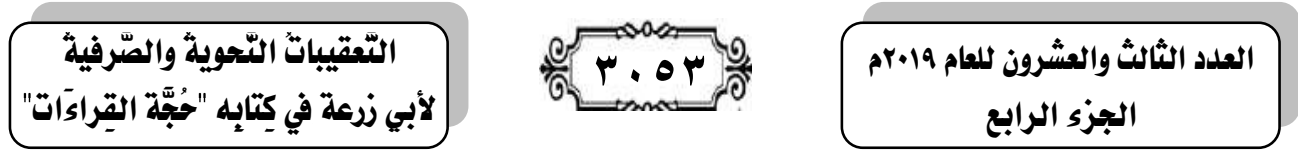

آراء بعض العلماء ذاكرًا اسمه في بعض الأحيان ، سواء كانوا علماء فقه ،

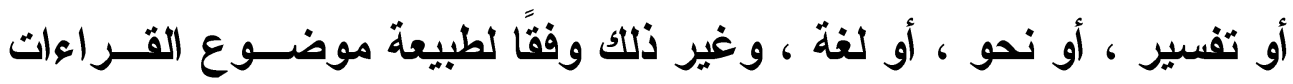
الو اردة.

وقد لاحظت أنَّ أغلب الحجج كانت تفسيرية دلالية ، ثم الحجج اللغوية،

ثم النحوية والصرفية ، وأخيرًا الفقهية.

كما لاحظت أنَّ أكثر من ذكرهم في أوجه اختيار القــراعات الكســائي

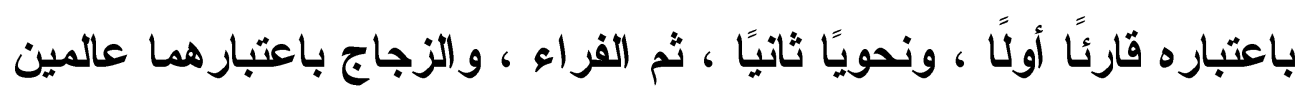
بالنحو، ولهما نصيب كبيز في التتأليف في كتب إعراب القرآن ومعانيه ، ثـــ اليزيدي باعتباره قارئًا نحويًا ، ثم أحمد بن فارس شيخه وأستاذه.

ثم إنَّه بعد ذكر حجج القزاعات كثيرًا ما يعقب ، وقد اتسمت تعقيباتــهـ النحوية والصرفية - وهي موضع الار اسة في هذا البحث - ببعض الأمسـور أذكرها فيما يلي : أني

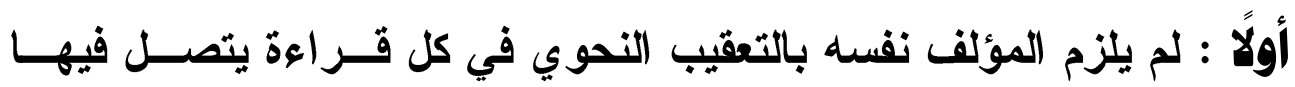
موضع التوجيه بالنحو، بل يوجد القليل من القراعات كـــان توجيههـــا نحويًا ، ولم يقم بالتعقيب عليها في نهاية الكلام (1).

ثانيـًا : خلت معظم التعقيبات النحوية والصرفية من نسبة الآراء إلى قائليها تصريحًا ، أو نسبتها إلى مذهبها (النحوي.

ثالثـأ : بعض التعقيبات جاعت في أول قر اعة في الآية ، وليس فـي آخــر قز اعزة)

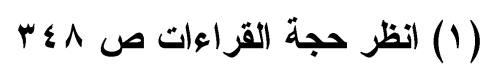

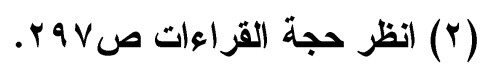

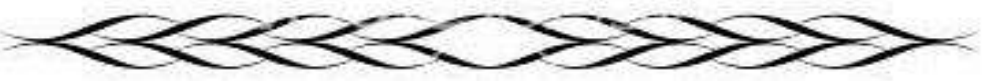




\section{الترقيم الدولخ}

ISSN 2356-9050
क.

حولية كلية اللفة العربية بجرجا مجية مجلة علمية محكمة

رابهًا : جاعت التعقيبات معبرة عن رأيه ، وفكره النحوي الخاص به.

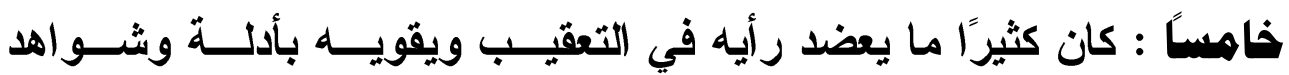

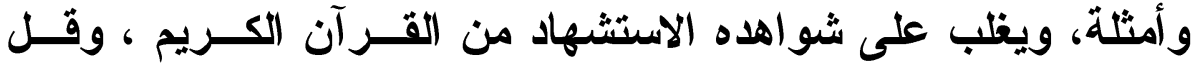
استثهاده بالحديث الشريف ، أو الشعر، وإن أورد لهما شواهد لم يكن يعزوها إلى راويها أو قائلها.

سادسًا : أورد الإمام أبو زرعة وجوهاً في القضية النحوية ، ورد ذكرها في كتب النحو، وآراء أخرى لعله مما انفرد بها مع ملاحظة أنَّها لم تسند

$$
\text { لله في كتب النحو ('). }
$$

سابهاً : استخدم أبو زرعة في بعض التعقيبات مصــطحات ، وأســاليب لا

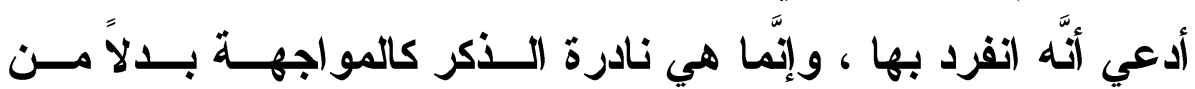

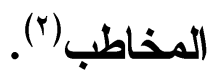

ثاهنـاً : يغلب على التعقيبات التفصيل لا الإيجاز، وفـي بعــ التعقيبـات النحوية ألحظ بعض الإيجاز ، ولكنَّه غير مخل مستخدماً مثثالاً واحـــاً

يفصل فيه ما أوجز ().

تاسهًا ، وأخيراً : العلة عنده في مجمل آرائه التي وردت في التعقيبات يظلب عليها العلل القياسية ، والسماعية ، وأذكر هنا بعضاً من أنواع العلـلـل التي وردت في تعقيباته النحوية والصرفية على سـبيل المثـال لا الحصر :

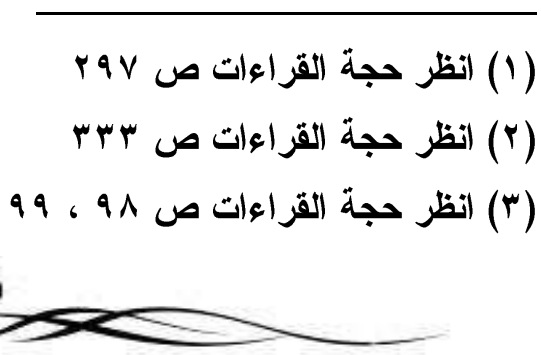


التّقيباتُ التّحوية والصّرفية لأبي زرعة في كِتابِه "حُجَّة القِراكَاتِ" r.00

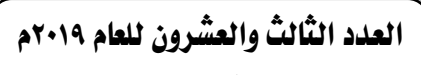
الجزء الرابع

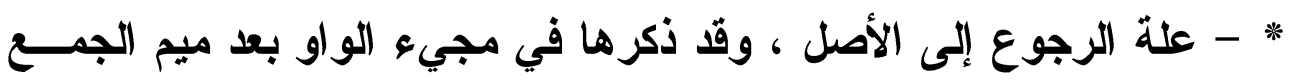

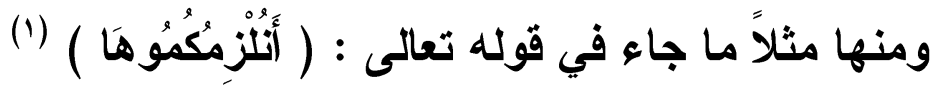

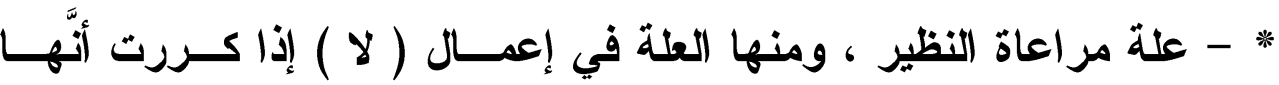

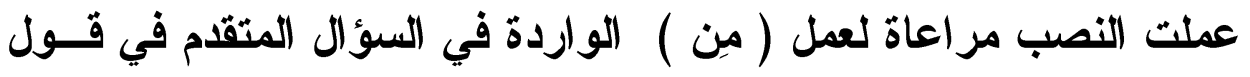

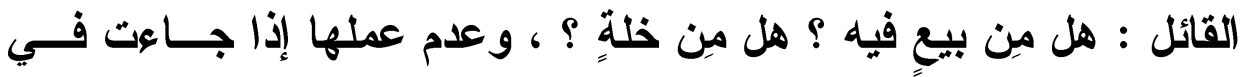

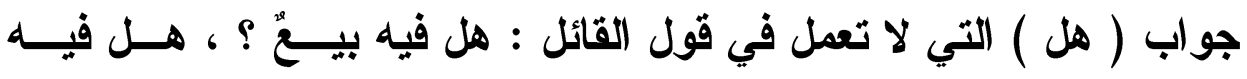

خلةُّو(؟)

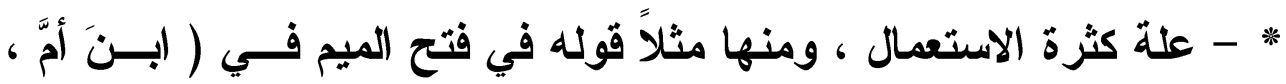

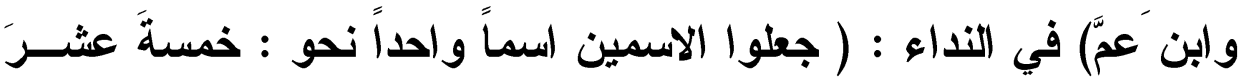

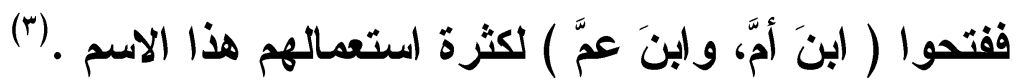

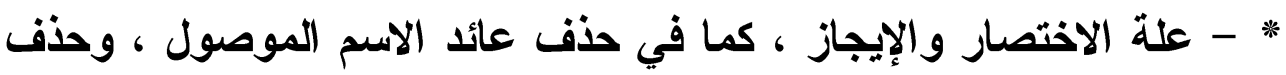

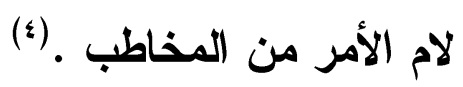

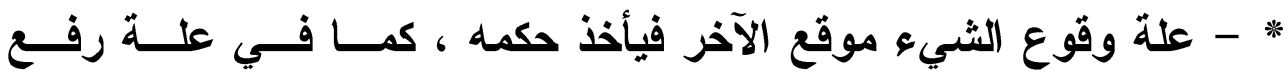

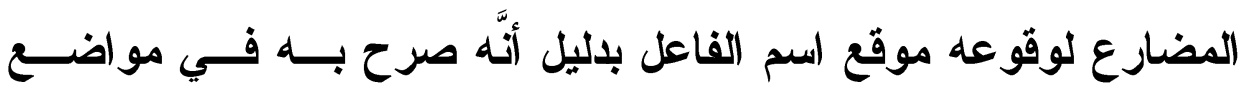
أخرى. (0)

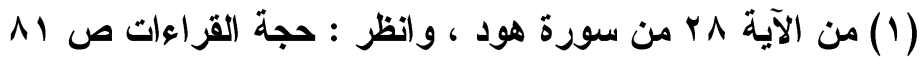

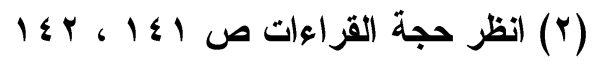

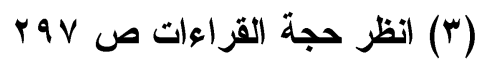

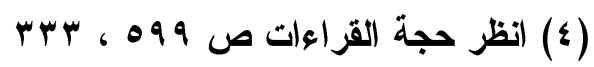

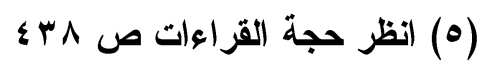




\section{الترقيم الدوله \\ ISSN 2356-9050}

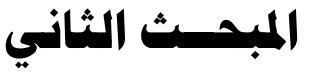

نبذة عن علم القراءات والتأليف في الاحتجاج لها وفيه أتناول ما يأتي :

\section{أولاً : تهريف علم القراءات}

هو : علم بكيفيات أداء كلمات القرآن الكريم من تخفيف ، وتثـــيا ،

$$
\begin{aligned}
& \text { واختلاف ألفاظ الوحي في الحروف(1). } \\
& \text { ثانيًا : أقسام القراءات . } \\
& \text { للازراعات قسمان : }
\end{aligned}
$$

الأول : متواترة صحيحة ، وهي ما حواها كتاب (حجـــة القــــراعات) لأبــي

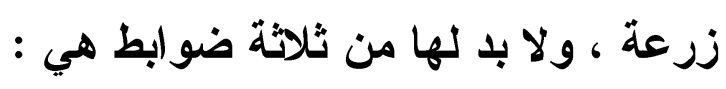

- - مواققة العربية ، ولو بوجه ، ومعنى ذللك أن توافق وجهًا مــن وجــوه

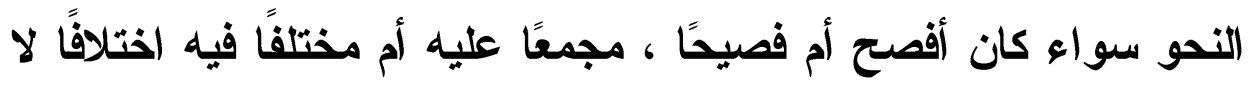

يضر منثله.

r) - مواققة أحد المصاحف العثمانية ولو احتمالًاً . r- بحة السند وتواتره.

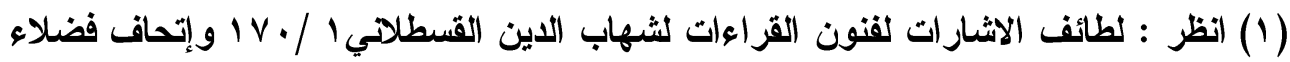

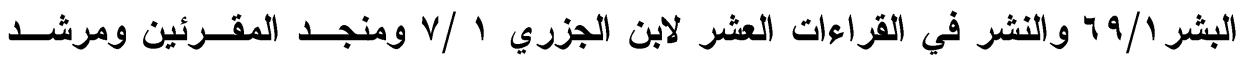

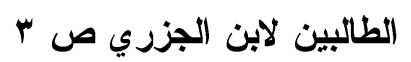

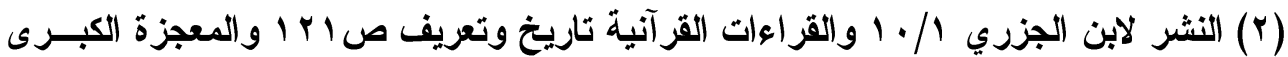

$$
\text { القرآن صبه }
$$



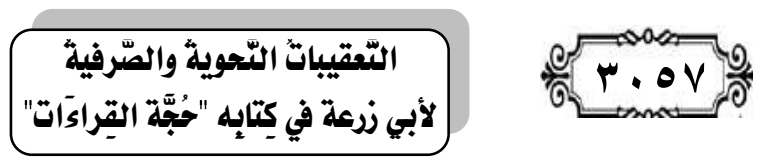

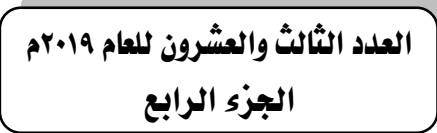

ويتحقق هذا كما يقول ابن الجزري : (أن يروي تلك القراعة العدل الضــابط

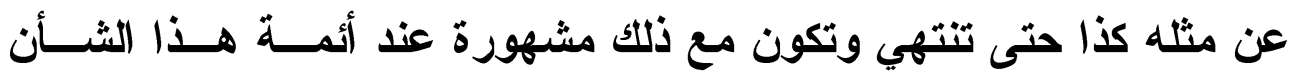

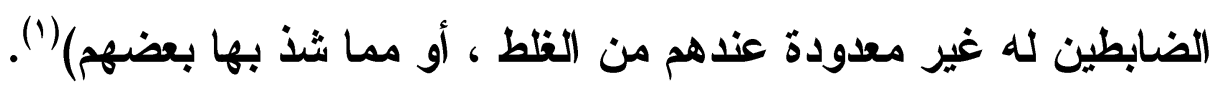
القسم الثاني : القراعات الثناذة .

وهي : ما اختل فيها ركن من أركان القراعة الثثلاثة المتقدمة .(؟) ثالثًا : تاريخ التأليف في كتب القراعات والاحتجاج لها . لم يكد يكتمل نزول القرآن الكريم وترتب سوره وآياتــه حتـى كسـان

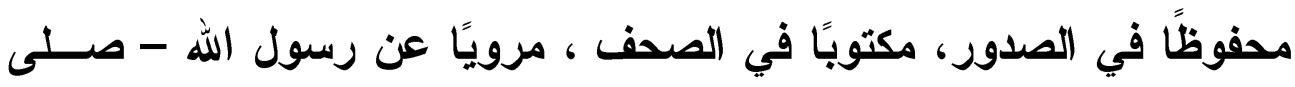

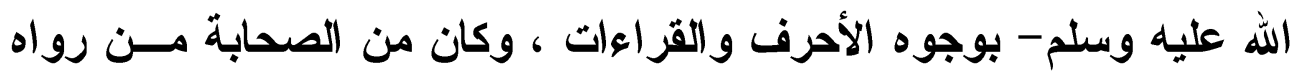

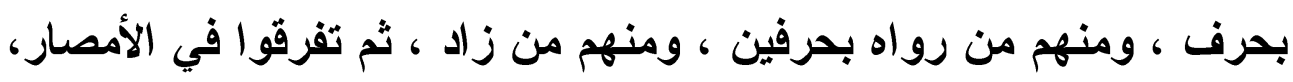

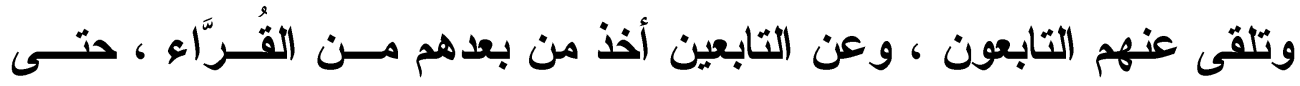

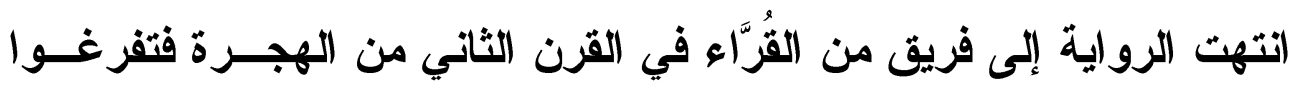

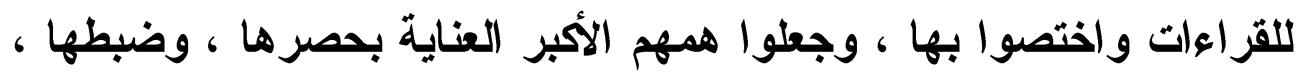

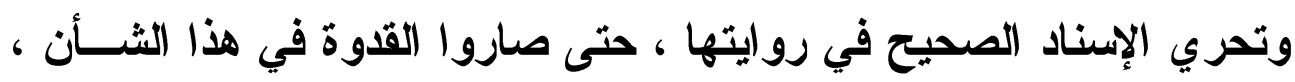

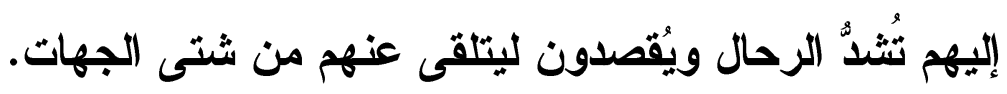

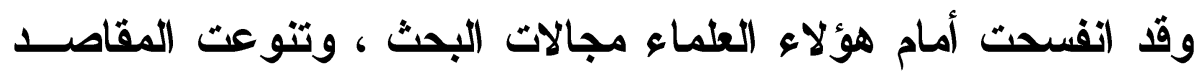

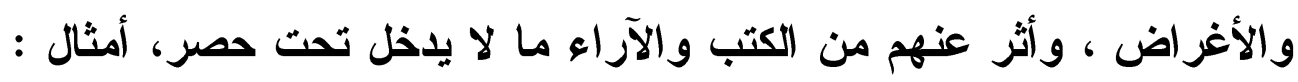

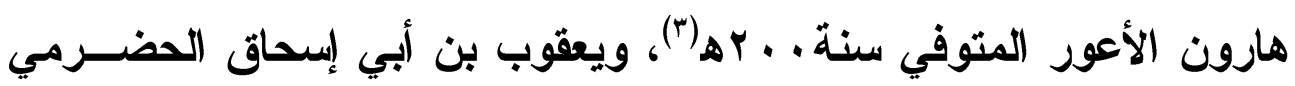

(1) النشر / / 1 1)، وينظر في شرط التواتر : الإتقان في علوم القرآن للسيوطي 100/1 .

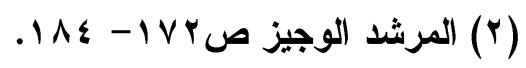

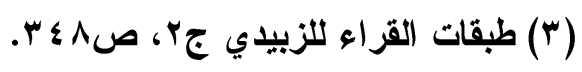




\section{الترقير الدولخ \\ ISSN 2356-9050}

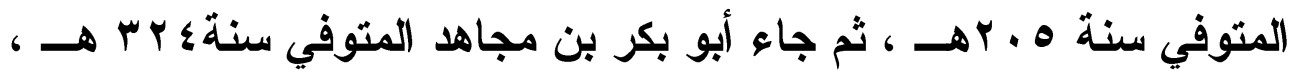
فألف كتابه الموسوم بـ "لإزراعات السبعة" فيكون أول من سبع السبعة.

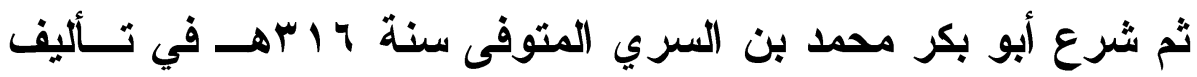
كتاب يحتج فيه للقز اعات الواردة في كتاب ابن مجاهد (1). وتوالت بعد ذللك المؤلقات في الاحتجاج للقــراءات ســواء القـــراءات السبع ، أم العثر ، أم الثاذة.

فكان تأليف القَُّّاء الكتب في جمع القراعات ونسبتها ، والبحث عـن

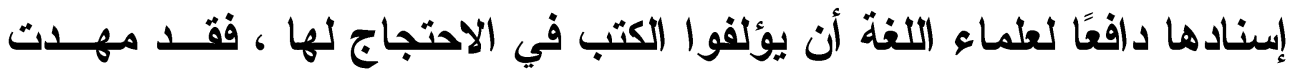
أمامهم السبيل ، ومدت لهم الأسباب ، فكان جمع القزاءات الخطوة الأولى ، والاحتجاج لها الخطوة التالية(؟).

\section{رابهًا : جهود علماء العربية في الامتجاج للاقراءات .}

بأ الاحتجاج أول العهد غضًا يسيرًا وكان يعتمد على القياس ، وحمل القزاعة على قراعة أخرى لمشابهة بينهما ، إمَّا في مادة اللفظ المختلف في قراعته ، و إمَّا في بنيته ، ثم أخذ يتجه مع ذلك إلى التخريج والاستشــهاد ، فبدأ بقراعة بعض الصحابة أمثال : عبد الله بن عباس المتوفي سنة 1 أهـ ،

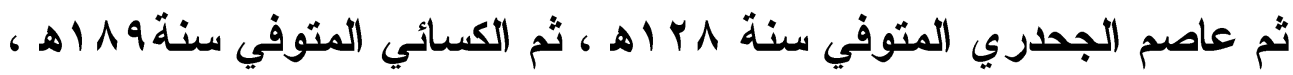
وسيبويه المتوفي سنة ، 1 اهـــ ، الأي أكثر فـي كتابــه مــن المفاضــلة والاحتجاج لبعض القراعات التي قرئت بها شواهده.

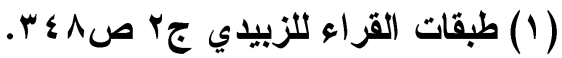

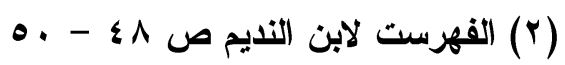



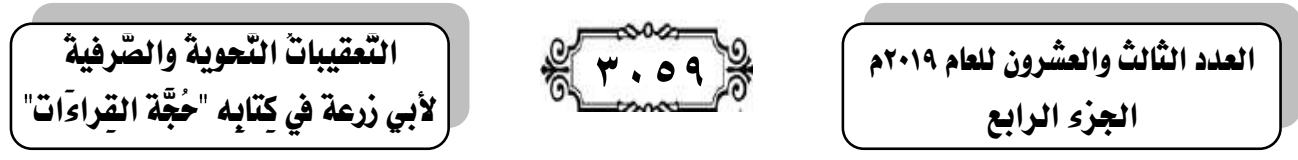

كما أكثرت كتب معاني القــر آن مــن التخريجــات لوجــوه الإعــراب

المختلفة، والاحتجاج لوجوه هذا الاختلاف (').

ومن العلماء الأين صنفوا في هذا الميدان : أبو علي الفارسي ، أحسـ أعيان القرن الرابع الهجري أزهى العصور الإسلامية ، و أكثرهـــا تصــنيفًا

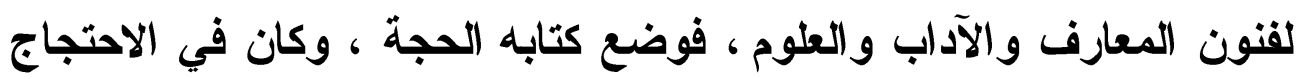

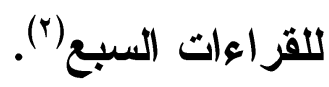

وسار على شاكلته الإمام القاضي عبد الرحمن بن زنجلة المكنى بأبي زرعة فألف حجة القراعات.

خاهسـاً : التر (بط بين التأليف في الاحتجاج للقراءات ، والتأليف في النـــو

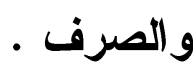

إنَّ العلاقة بين التأليف في القراعات وبين التأليف في علوم العربية ،

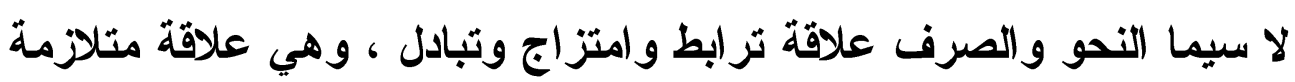

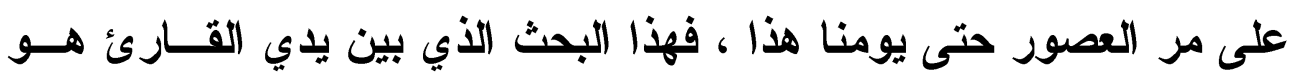
نموذج حي لهذا التز ابط و الامتز اج.

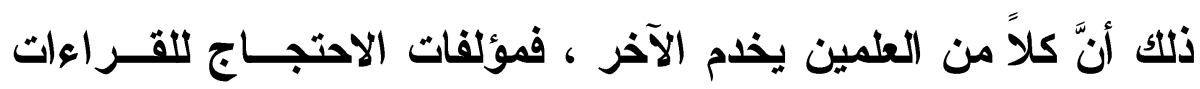

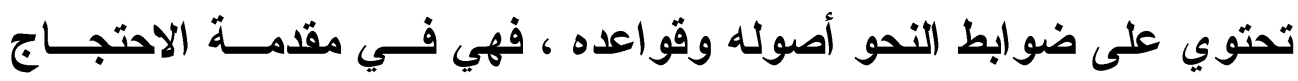

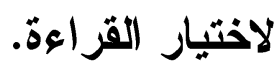

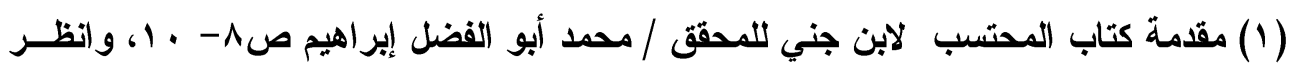

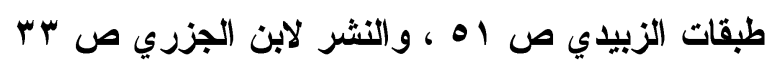

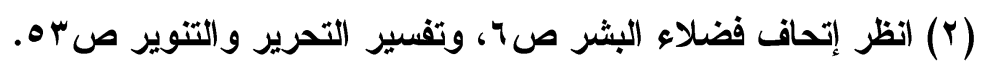




\section{الترقير الدولخ \\ ISSN 2356-9050}

أمَّا علوم العربية فإنَّ المادة الأساس في كل علم منهـــا هـــي آيــات القرآن الكريم ، وقر اعاته المختلفة فبحثها ، ودر استها ، والاستثــهاد بهـــا كان مجالًا رحبًا لكل من يتصدى لعلوم العربية التي كما سبق أن أثرت إلى

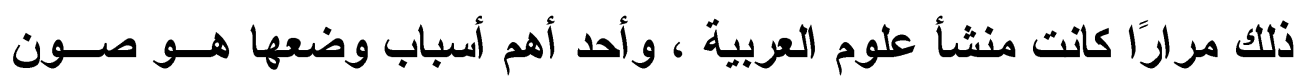
اللسان عن الخطأ في قراعة القرآن الكريم ، والاحتجاج لقراءاتـــهـ ، فـــهب العلماء يشرحوا غريب كلماته ويحتجوا لأوجه قر اعاته و إعر ابه وغير ذلك. ولم يكن ذلك خاصاً بأحد أفرع العربية دون الآخر، بل إن جميعها كان ذلك شأنه ، فعلوم البلاغة همها جلاء روعة البيان القرآني لتوجيه النــاس لينذوقوا حلاوته.

لذا كان أمرًا طبيعيًا قيام أئمة القَُّّاء بلدر استة علوم العربيــة ، وكـــان كبارهم أئمة في العربية أيضًا ، أمثال : أبي عمر بـن العــلاء ، ويعةـوب الحضرمي حتى الكسائي في الكوفة ، وهذا الإمام ابن مجاهد مسبع السبعة ،

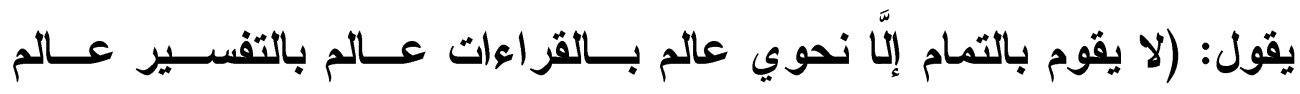
بالقصص وتلخيص بعضها من بعض عالم باللفة التي نزل بها (القرآن)('). وتعد المائة الثالثة من الهجرة عصر التأليف في القراعات ، ووقتهــا اتسع أيضًا التأليف في العربية كاتساع التأليف في القراعات. ذلتك أنَّ الوجوه النحوية - كما سبق - كانت من جملة ما احتكموا إليه في المفاضلة بين القزاعات. 
التعقيباتُ التّحوية والصّرفية

لأبي زرعة في كِتابهه "حُجَّة القِراكَاتِ"

فإذا جاعت المائة الرابعة ألفت أيضًا كتب كثيرة في الاحتجاج للقراعات

منها : كتاب لأبي بكر محمد بن السري المسمى (احتجاج القراعة)(1).

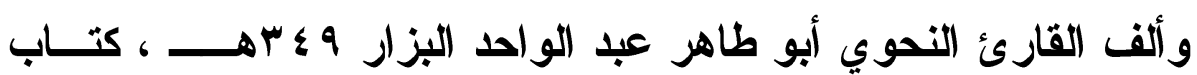

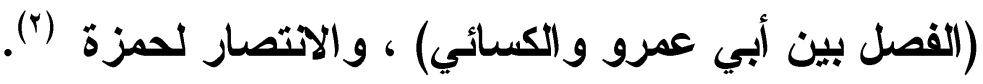

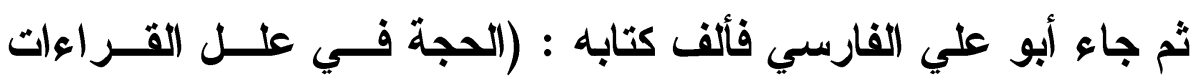

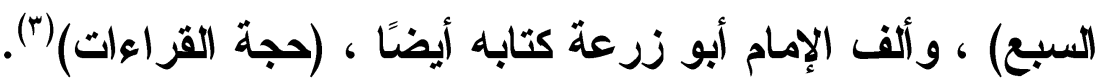

كما ازدهر أيضًا التأليف في النحو والصرف ، وزخــرت المكتبــة العربيــة

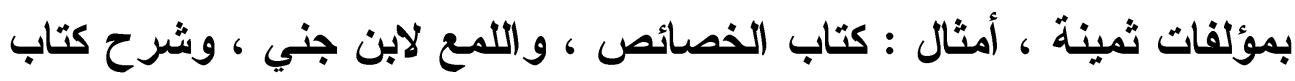
سيبويه للسير افي ، و التذكرة لأبي علي الفارسي ، و البغدادئ لاديات له أيضًا.

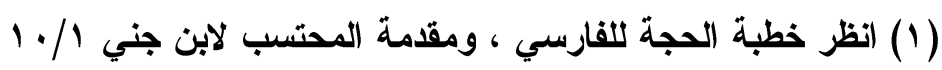

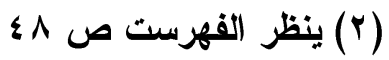
(T) وهو الكتاب موضوع البحث تحقيق / الأستاذ سعيد الأفغاني 


\section{الترقيم الدولم ISSN 2356-9050}

Q.
حولية كلية اللفة العربية بجرجا مجلة علمية محكمة

\section{الفصل الأول}

تعقيبات أبي زرعة النحوية

باب المعرب والمبنى

\section{فعل الأهر بين الإعراب والبنلاء}

قال الإمام أبو زرعة : (اعلم أنَّ كل أمر للغائب والحاضر لا بد من لام العام

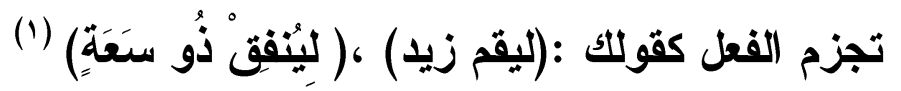

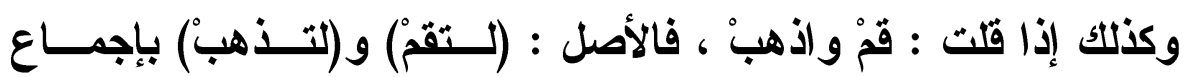

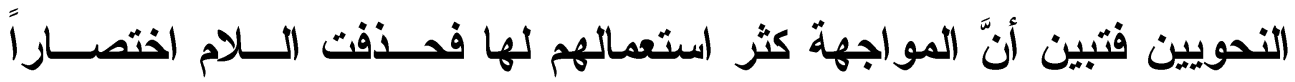

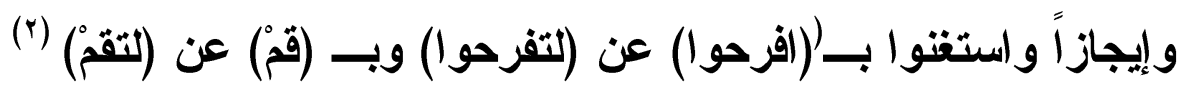

مـا تضمنه كلامه من أفكار :

1 - ذكر أبو زرعة أنَّ الأصل في أمر المخاطب أن يكون باللام كأمر الغائب.

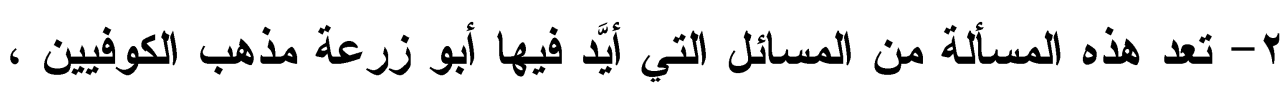

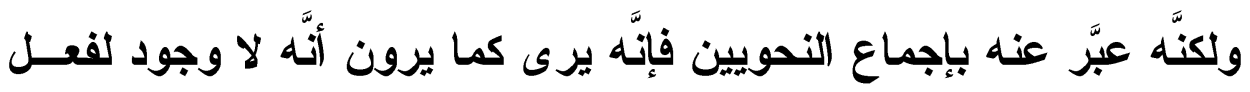

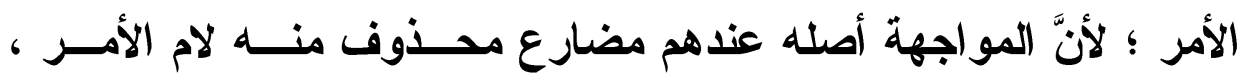

$$
\text { وحرف المضارعة . }
$$

ب- أطلق أبو زرعة مصطلح المواجهة على أمر المخاطب .

ع - ذكر أنَّ العلة من حذف لام الأمر في أمر المخاطب هي كثرة الاستعمال. ه- لم يذكر أبو زرعة حذف حرف المضارعة مع لام الأمر من المضارع.

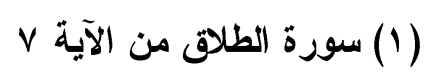

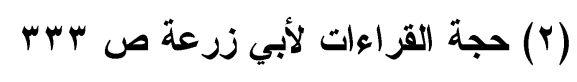


التصقيباتُ التّحويثة والصّرفية لأبي زرعة في كِتابه "حُجَّة القِراءَاتَ"

عرض القضية النحوية في دخول لام الأمر على الفعل :

تلخل لام الأمر للغائب مثل : ليقم زيد ، وكان القيــاس فــي أمسـر الفاعـل

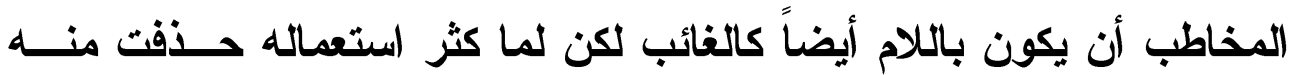

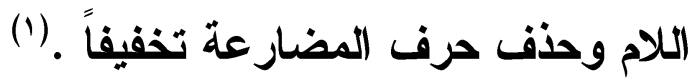

ويجدر بي هنا أن أذكر مفهوم الأمر وكيفية صياغته فأقول :

الأمر: طلب الفعل بصيغة مخصوصة ، فإن كان للغائب بقــي علــى صــيغة المضارع ولحقت به لام الأمر ، فيقال : ليقم .

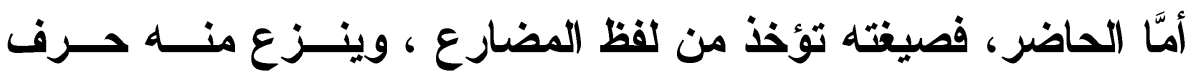

المضارعة، فإن كان ما بعد حرف المضارعة متحركاً بقي على حركته نحــو

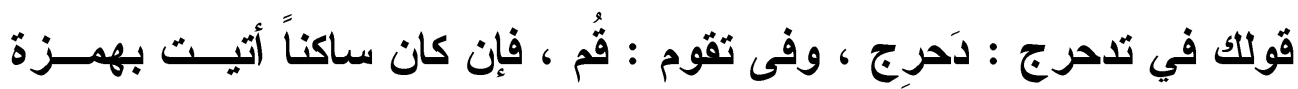
الوصل مثل : يستخرج تقول : استخرِج ، وإن أخذ لفظ الأمر من المضــارع

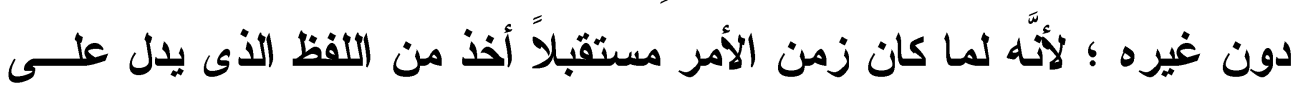
الاستقبال وهو المضارع . (r) ومما سبق يتضح أنَّ العلة في بناء الأمر هي زوال مشابهة الاسم بعد

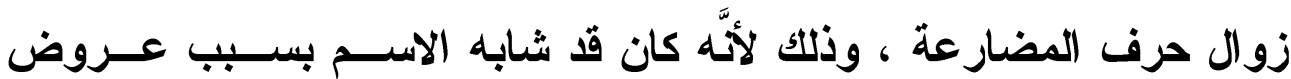

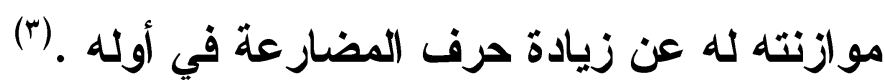
وبزوال حرف المضارعة منه خرج عن كونه معرباً فلم يـــخل عليـهـ العامل ، وهذا الذى ذكرته يكون في الأمر للمخاطب ، أمَّا ما كان للغائب من

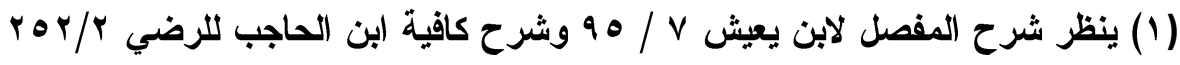

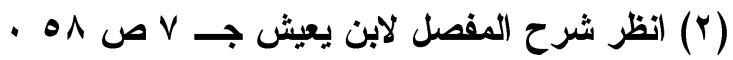

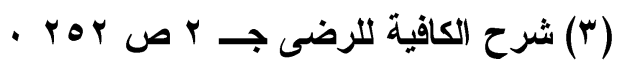




\section{الترقير الدول\$ \\ ISSN 2356-9050}

الأفعال المأمور بها تذكر فيها اللام ؛ لأنَّهَه لم يجز حذف حـرف المضــارعة

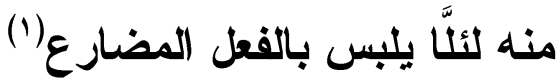

وقد نُسب إلى الكوفيين القول بأنَّ أمر المضارع معرب لا مبنى نظــراً

لأنَّ أصله مضارع مجزوم بلام الأمر (r).

وهذا نلاحظ أنَّه قد حذف من فعل الأمر للمخاطب شيئان :

الأول : حرف المضارعة ، والثاني : لام الأمر.

وأستطيع أن أثشير هنا إلى أنَّ النحويين اتفقوا على أمور:

الأمهر الأول : لزوم لام الأمر لفعل غير المخاطب .

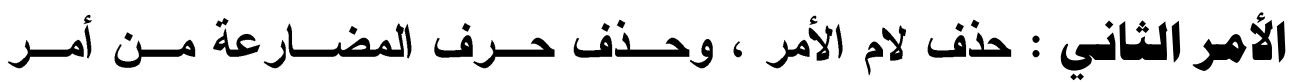
المخاطب.

الأهم الثالث : إذا جاء فعل مقترناً بلام الأمر فهو مضارع مجزوم بها. الأهمر الرابع : أنَّ العلة في حذف حرف المضارعة ولام الأمسـر فـي أمسـر الحاضر هي كثرة الاستعمال("). كما أود الإثارة إلىى أنَّهم اختلقو أفي أمرين :

الأهمر الأول : اختلاف البصريين والكوفيين في بناء الأمر الحاضــر

و إعرابه ، فيرى البصريون أنَّ فعل الأمر مبني ، لأنَّ أصل الأفعال كلهــــأن أن

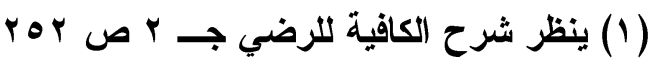

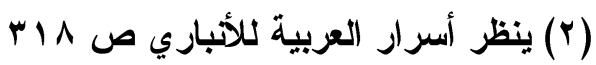

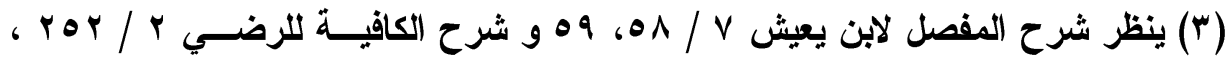

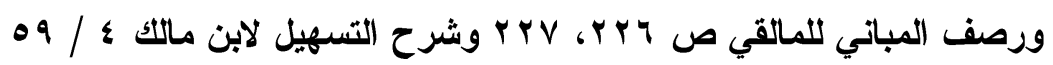




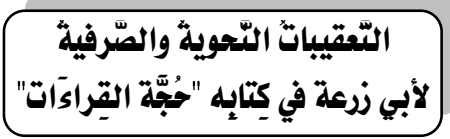

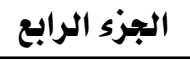

تكون موقوفة الآخر، ويرى الكوفيون أنَّ فعل الأمر معرب مجزوم بلام أمسر مضمرة) (1)

الأهر الثاني : اختلفوا في الأمر الخالي من اللام ، والأمر الأى باللام • فذهب البصريون إلى أنَّ الذى خلا من لام الأمر هو صيغة فعل الأمر، وهى قائمة بذاتها مستقلة ، والذى بالكلام هو مضارع مجزوم بلام الأمر. ويرى الكوفيون أنَّ كليهما فعل مضارع ، في الأصل معرب بالجزم بلام ظاهرة ، أو محذوفة قياساً على سائر أفعال الأمر.

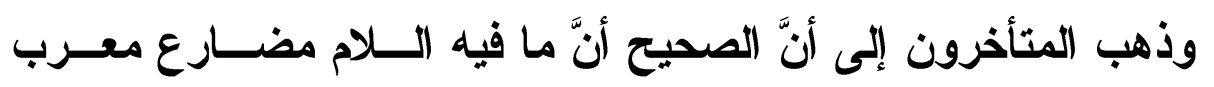

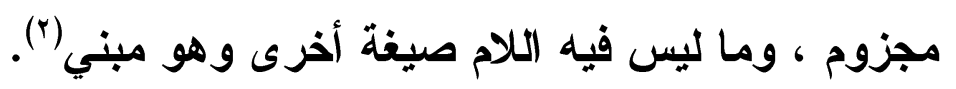
وأخيراً أستطبع القول فيما سبق من آراء.

أنَّ أصل الأمر مأخوذ من المضارع المقترن باللام ، وهذا ما ذهب إليه

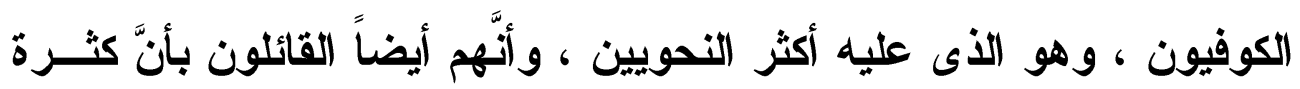
الاستعمال هي علة حذف لام الأمر. أمَّا أبو زرعة فقد علل الحذف بأنَّه للاختصار والإيجاز ، والاســنغناء

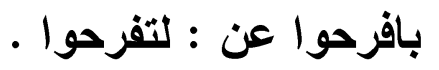
وأنَّ ما ذكره أبو زرعة قد جاء مواققاً لما ذهب إليه أكثر الكوفيين وقد

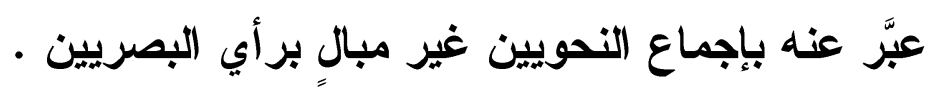

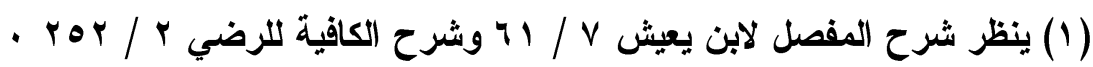

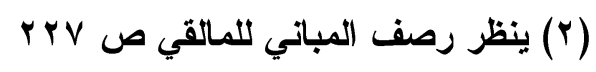




\section{الترقيم الدوله ISSN 2356-9050}

\section{باب النكرة والمتهرة}

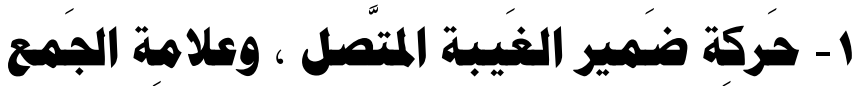

قال الإمام أبو زرعة : ( واعلم أنَّ الأصل في( علــيهم) (عليهُهــو) بضم الهاء و الواو بعد الميم - والاليل على ذلك أنَّ هذه الهاء للمذكر تضـــم وتثبع ضمتها فيتولا عنها الواو نحو: ضريتهو ، وإذا فتحت كاتت للمؤنــث

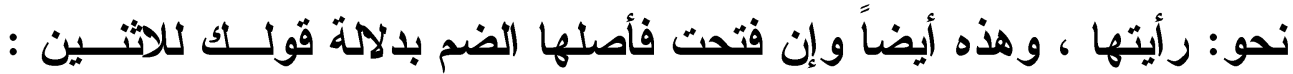
رأيتهما وللجماعة : رأيتهنَّ ، وعلامة الجمع في المذكر إلى هذه الهاءه هـي الميم المضمومة التي بعدها (واو) كما فـي قـولكم :(ضـــربتكم) وأصــله :(ضربتكمو) يتبين للك ذلك إذا اتصل به مضمر آخر ترد معه الواو نحــو : (ضربتكموه) ولا تقول : ضربتكمه.

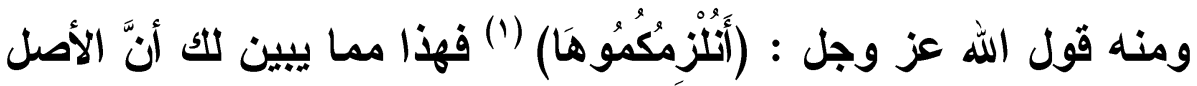

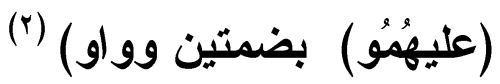 ها تضمنه كلامهه هن أفكار :}

* - بيَّن أبو زرعة حركة هاء ضمير الغيبة المتصل فنكر أنَّ الأصل فيهــا الضم ، ودلل على ذلك بأدلة منها : 1 - أنَّ الضم إذا أثبع تولا عنه واو في نحو: ضربته. r - أنَّ الهاء إذا فتحت صارت للمؤنث لا للمذكر نحو: رأيتها . 
r - أنَّ هذه الهاء حتى وإن فتحت فأصلها أيضاً الضم بــليل ضـــها فـي التثنية و الجمع : رأيتُهُها ورأيتهُهنَّة .

* - ثم بيَّن حركة ميم الجمع الواقعة بعد هاء الغيبة فذكر أنَّ الأصل فيهــا أيضاً الضم وتأتى بعدها الواو ودلل على ذلك بالآتي :

أنَّهـ إذا اتصل به مضمر آخر ردث الواو معه نحو: ضــربتكموه ، ولا

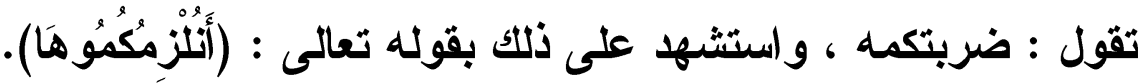
رأي النحويين في حركة هاء الغيبة ، وعلامة الجمع : أود هنا الإثارة إلى شيئين : حركة هاء الغيبة ، ثم أتلوها بحركة علامة الجمع فأقول : حركة هاء الغيبة : إنَّ هاء الغائب من الضمائر المتصلة التي تشتعمل في موضعي النصب

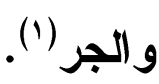
من خلال الاطلاع على ما ذكره النحويون أستطيع الإشارة إلى أنَّهـ لــم يكن بينهم خلاف في أنَّ الأصل في الهاء الضم ، وأنَّها تخرج عن هذا الأصل إذا كان قبلها ياء ، أو كسرة فتكسر. وقد علل سيبويه لذلك بقوله : (لأنَّها خفية كما أنَّ الياء خفية ، وهـي من حروف الزيادة كما أنَّ الياء من حروف الزيادة ، وهى من موضع الألف ، وهى أثبه الحروف بالياء) (r).

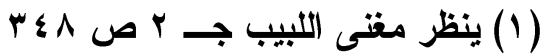

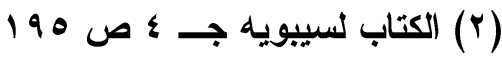




\section{الترقيم الدولخ}

ISSN 2356-9050

وقد استعمل الحجازيون هذه الهاء دون خروج عن الأصل.

قال ابن مالكك :( ولغة الحجازيين في هاء الغائب الضم مطلقاً ، وهو الأصـل

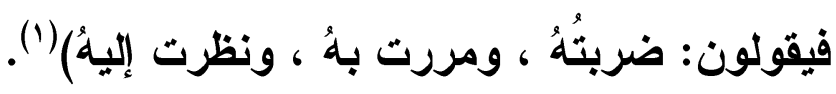

أمَّا لغة غير الحجازيين فهي الكسر بعد الكسرة ، أو الياء الساكنة من قبيل الإتباع.

وعلل ابن مالك لألك بأنَّ اللافظظ بذلك بعد ساكن كالجامع بين الساكنين

فلذلك كثر اختلاس الضمة و الكسرة في نحو: منه (؟).

أمَّا حركة علامة الجمع :

فقد أورد لها النحويون أحوالاً :

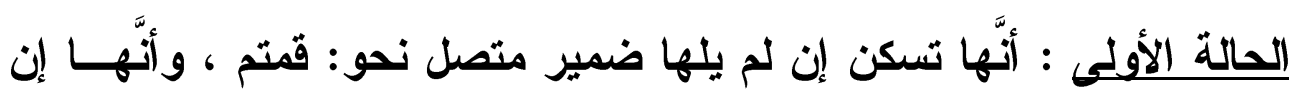
وليها ضمير لم يجز إسكانها.

الحالة الثثانية : أنَّها تكسر إذا كسرت هاء الغيبة إتباعاً لها وأرجع سـيـيويه العلة في ذلك إلى كراهة الضمة بعد الكسرة(").

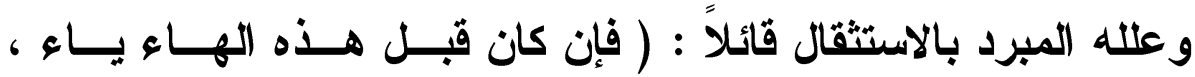
أو كسرة كان الأحسن أن تبال من ضمنها كسرة لاستثقالهم الضمة بعد الياء

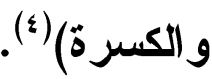

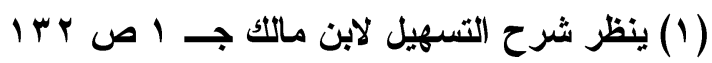

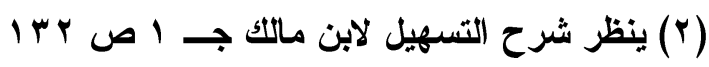

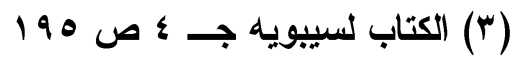

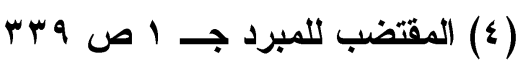


التققيباتُ التّحويثة والصّرفية

لأبي زرعة في كِتابه "حُجَّة القِراءَات" r. 49

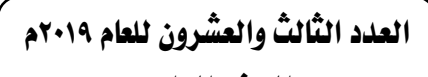

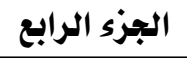

وهذا أيضاً ما ذكره (بن مالكك فقال معللاً : (وكسر ميم الجمع بعد كسر

(الهاء أقيس من ضمها ؛ لأنَّ الخروج من الكسر إلى الضم ثقيل) (').

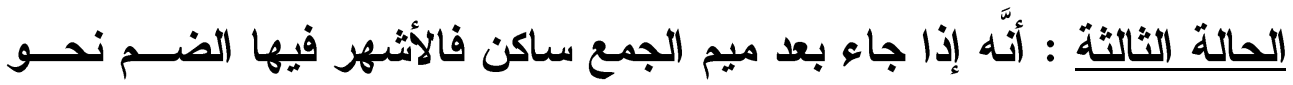

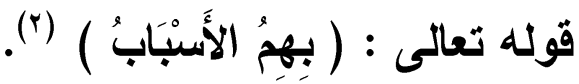

قال ابن مالك :( وقد تكسر قبل ساكن وإن لم يكن قبلها كسرة ولا ياء

ساكنة (َ) الن

أمَّا عن حكم الواو الواقعة بعد ضمير الغيبة وميم الجمع فالذي فهم من

كلام النحويين يشير إلى الآتي :

1 - إلحاق الواو بعد الضمير هو الأصل .

r - أنَّ هذه الواو تثتبت في الوصل وتحذف في الوقف.

وقد ذكر المبرد ذلك وأضاف معللاً له بقوله : (فالأصل في هذا الضــمير أن

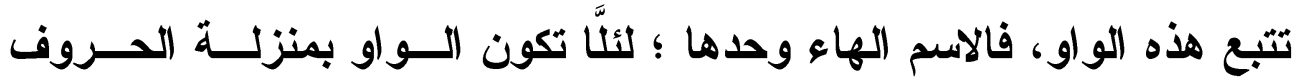
الأصلية وذلك قولك : رأيته وأعطيته ، إذا وققت) (4).

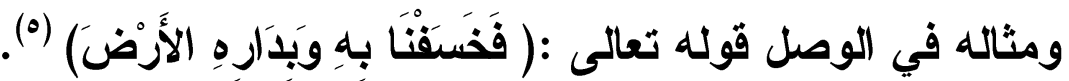

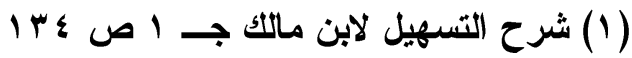

$$
\begin{aligned}
& \text { (Y) سورة البقرة من الآية } 179
\end{aligned}
$$

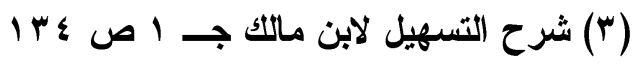

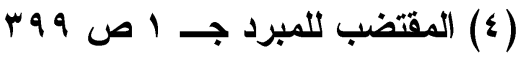

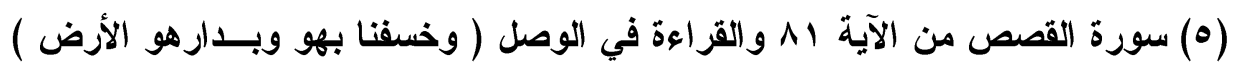

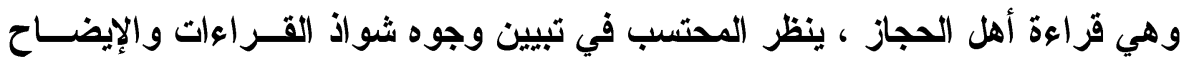

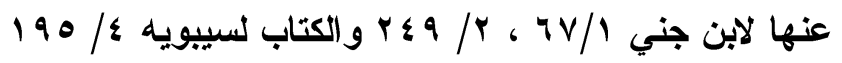




\section{الترقير الدولخ}

ISSN 2356-9050
T.

حولية كلية اللفة العربية بجرجا مجلة علمية محكمة

ومثله أيضاً :أعطيتهو يا رجل ، وجاعني غلامهــو فــاعلم ، ورأيـــ غلامهو يا فتى ، ومررث بغلامهو ، ومررث بهو فاعلم.

وقد فهم من كتب التحو التي تيسر لي قراعتها أنَّ لهذه الـــواو ثنلاثــة أحكام : ثبوتها في الوصل ، وحذفها في الوقف ، وإبدالها ياء إذا سبقت هاء الغيبة بياء أو كسرة ، فالأفضل لاى الجميع أن تبدل ضمة الهاء إلى كسـرة كما سبق ، وأن تبدل الو او ياء.

هذا ما قرره سبيويه وغيره من النحويين(').

وأكد المبرد أنَّ الرجوع إلى الأصل في كل الأحوال عربي جيد(؟).

من كل ما سبق ومن خلال ما ذكره أيضاً أبو زرعة يمكن القول : بأنَّ

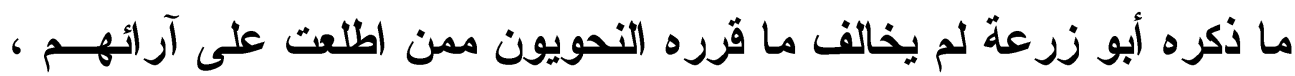
وأنَّ الأدلة التي ذكرها أبو زرعة أدلة قوية وواضحة ، وأنَّ طريقة عرضــهـ للمسألة فيها شمولية وسلاسة وتسلسل مفيد ، وقد راعى ذكر العلة في هذه

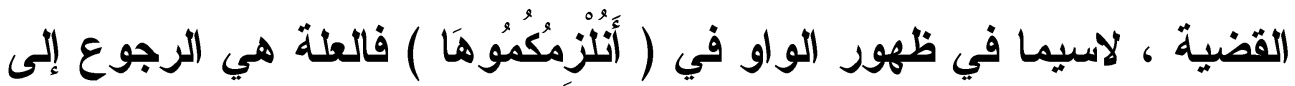
الأصل إذ الأصل في هاء الغيبة الضم الأي يتولا عنه واو • كما أود الإشارة إلى أنَّ هذه المسألة ليست من مسائل الخلاف. 


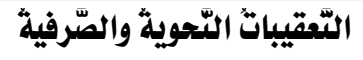

لأبي زرعة في كِتابه "حُجَّة القِراءَات"
H.V.

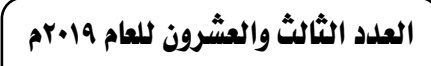

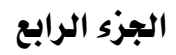

\section{r - جَمَع ( التَّي )على اللاتي أو اللائي ، وجَمَع البَمَع على اللواتي}

قال الإمام أبو زرعة :(واعلم أنَّ هذه الوجوه كلهــا جمــع (التــي)

والعرب تجمع (التي) على : اللاتي واللائي ، ثم يجمعون الجمع فيقولـــون:

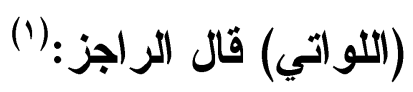

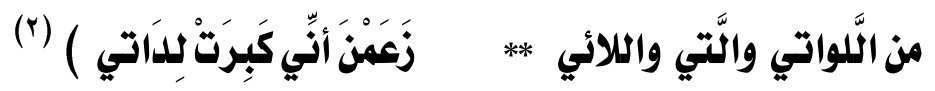

ما تضمنه كلامه من أفكار :

1 - ذكر الإمام أبو زرعة عدة جموع في( التي ) منها :

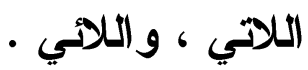

وأضاف في قراءة : اللاءع بالكسرة بلا مد .

واللاتٍ بالكسرة بلا مد ولا همز ·

وذكر أنَّ ترك المد والههز للتخفيف ، وهذه لغات عن العرب .

r - اللائي بهمزة بعدها ياء ، ونسب ذلك لأهل الكوفة.

r - ما سمع عن العرب في جمع (التي) : اللاني واللاتي.

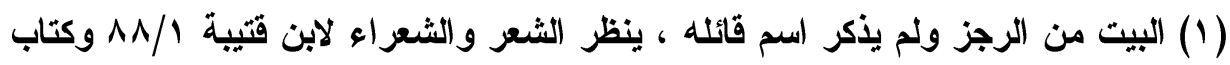

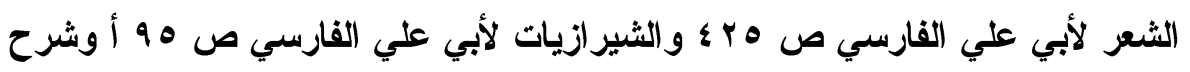

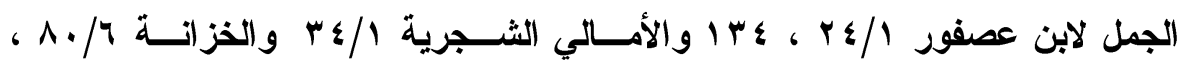

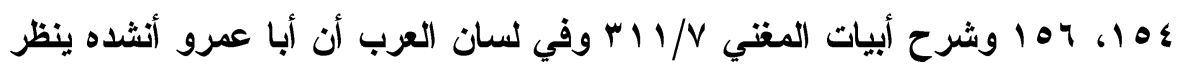

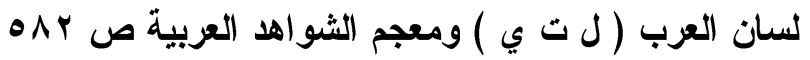

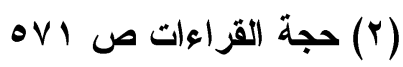




\section{الترقير الدولخ \\ ISSN 2356-9050}

ع - أنَّ اللواتي ليس جمعاً للتي وإنَّما هي : جمع اللاتي فهـي إذن جـــع

الجمع.

ه - أنَّ اللاهي بالاهزةة جمع للتي على غير لفظها . צ - أنَّ اثبات الياء في جمع التي هو الأصل ، وهو القياس .

ما ذكره النحويون في جمع ( التي ) :

تحدثت كتب النحو كثيراً عن (التي) وكثر فيها الحديث ؛ لأنَّ من ألفاظ الاسم الموصول ( التي ) تستخدم للمفرد المؤنث ، وقد عزا ابـن الحاجـب للكوفيين قولهم: إن أصل (الأى) هو الألال فقط فلمَّا أرادوا إدخال اللام عليها زادوا قبلها لاماً متحركة ؛ لئَّاّ يجمعوا بين الــذال الســاكنة ولام التعريــف الساكنة ، ثم حركوا الأل بالكسرة وأثبعوا الكسرة فتولات الياء.

وحملث (التي) على (الذي) بعد قلب الذال تاء واستخدمث للمفرد المؤنث(').

أمَّا عن جمعها فقد ذكر النحويون عدة أوجه منها : اللاتي ، و اللاتي ، واللواتي بإثبات الياء. ومنها: اللاتِ ، و اللواتِ بحذف الياء.

ومنها : اللا ، واللوا بحذف الياء والحرف الأى قبلها (r) وإذا حذفت الياء في كل ما سبق في الحرف الأخير بعد الحذف وجهان : البناء على الكسر ، أو إعرابها إعراب أولاتِ الملحق بجمع المؤنث السالم .

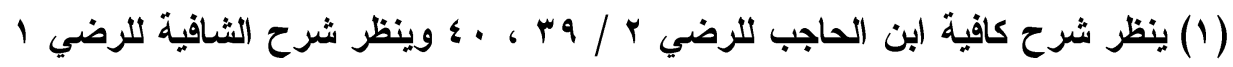
r^^ /

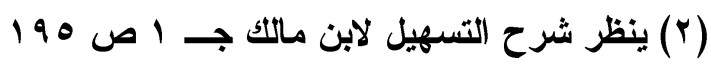


التققيباتُ التّحويثة والصّرفية لأبي زرعة في كِتابه "حُجَّة القِراءَاتَ"

وقد فصَّل ابن مالك القول في نوع اللاتي ، فنكر فيها وجهين :

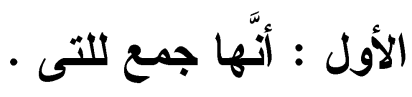

والثاني : أنَّها اسم جمع ، وذكر لكل وجه دليلاً .

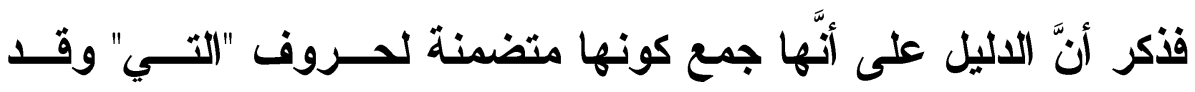

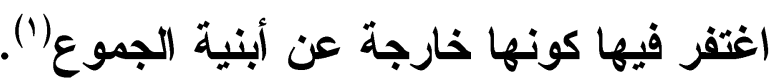

وعلى اعتبارها اسم جمع فنظراً لكونها ليست على بناء الجمع(؟).

وأغلب شراح الألفية قصروا جموع (التى) علــى : اللاتـــي واللاهــي

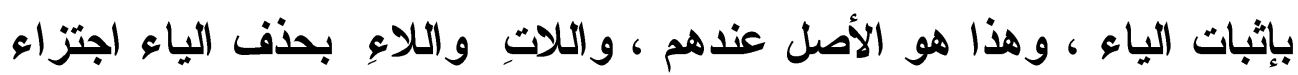

بالكسرة عنهات آنات.

بينما ذكر العكبري (\&) ، وابن مالك (0) جموعاً أخرى حيــث أجسازا

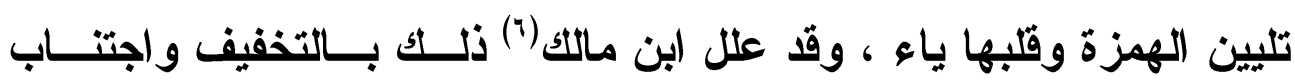
الاستطالة .

أمَّا عن الاقتراض بين الأسماء الموصولة لجمـعِع المـــكر والأســماء

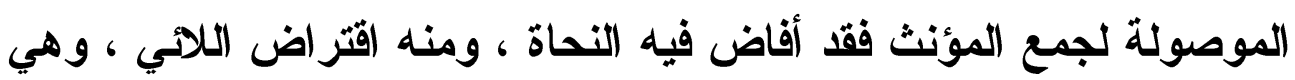
المستعملة في جمع المؤنث وبين اللاثي المستعملة في جمع المذكر .

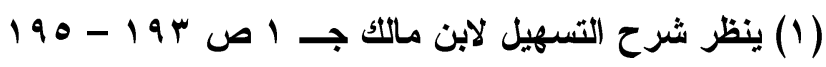

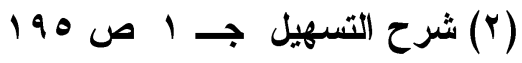

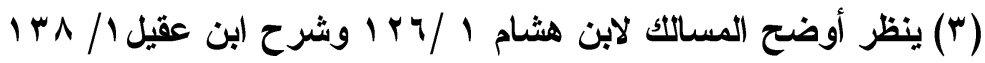

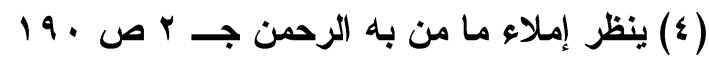

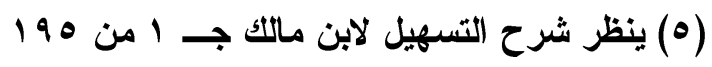

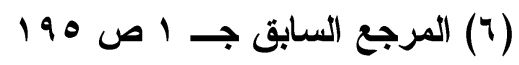




\section{الترقير الدولخ}

ISSN 2356-9050
r.VE
حولية كلية اللفة العربية بجرجا مجلة علمية محكمة العربة

وأنَّ أصل اللاهي المستعملة في جمع المذكر: اللانين ثم حذفت النون ،

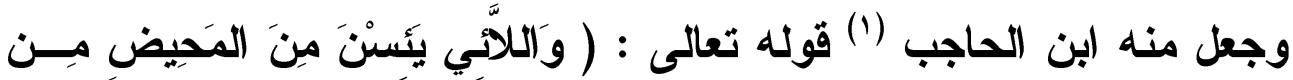

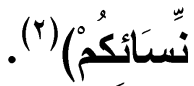

ومنه أيضاً استعمال اللائي المستعملة لجمع المذكر السالم - بحـــف

الياء- فيقال : اللاء ، كما يقال في اللاهي التي لجمع المؤنث : التلاء().

أمَّا ما ذكره أبو زرعة من أنَّ (اللواتي ) جمع الاتلي فقد صــرح بــه

\section{بعض العلماء كالزمخشري (\&)}

وقال الرضى : (و اللواتي و اللوائي كأنَّهما جمعا الجمع) (•) بينما صرح ابن مالك بأنَّ (اللواتي ) جمع التي.

وأخيراً : فإنَّ ما ذهب إليه أبو زرعة قد أثشار إليه النحويـون فـي

كتبهم مما قر أت لهم وكان كلامه في هذه المسألة دقيقاً وجديراً بالدر اسة .

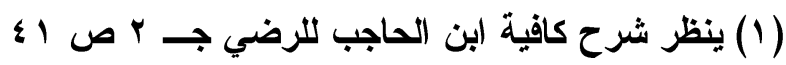

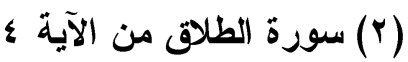

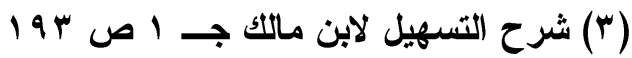

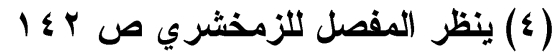

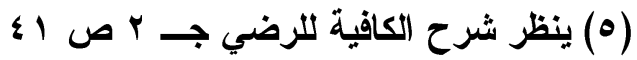


التققيباتُ التّحويثة والصّرفية لأبي زرعة في كِتابه "حُجَّة القِراءَات"
P.VO

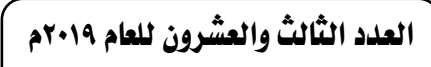
الجزء الرابع

\section{r - مذف العائد في باب الموصول}

قال أبو زرعة : (واعلم أنَّ العرب تضمر الهاء عائســـة علــى (مَـنـ)

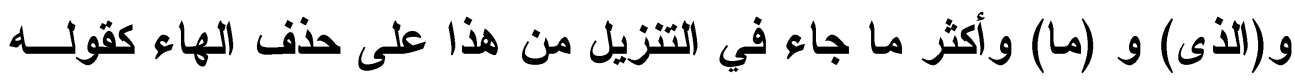

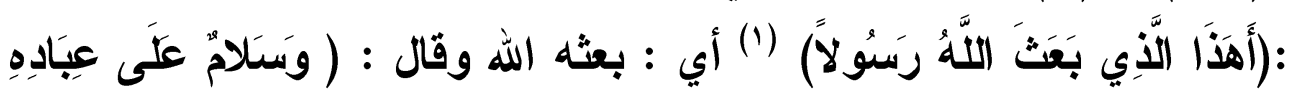

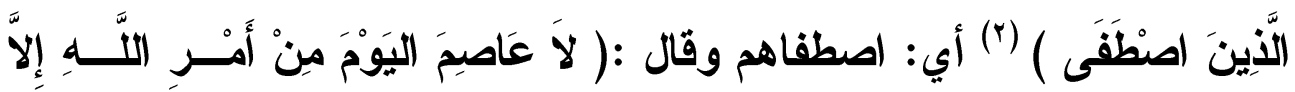

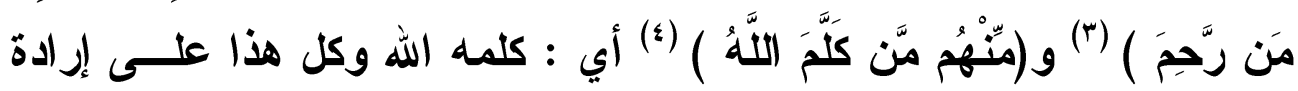

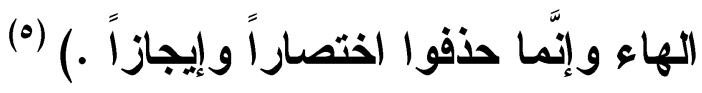
ما تضمنه كلامه من أفكار : 1 - تناول الإمام أبو زرعة قضية حذف العائد على الموصـول الاســى

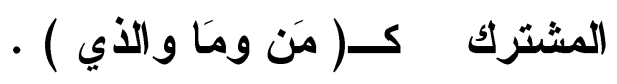

r - ذكر أبو زرعة ثلاثة من الأسماء الموصولة علــى سـبيل المثــال لا

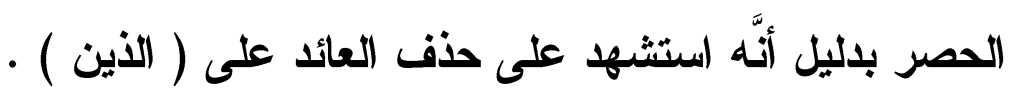
r - اقتصر أبو زرعة على الثواهد القرآنية . ع - أعقب كل شاهد بتقدير الكلام قبل حذف الضمير العائد . ه - خص أبو زرعة الهاء من بين الضمائر المحذوفة التي تعود على الاسم

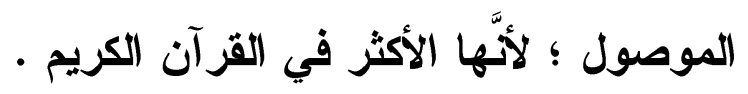

$$
\begin{aligned}
& \text { (1) سورة الفرقان من الآية 1) }
\end{aligned}
$$

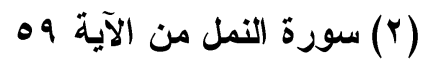

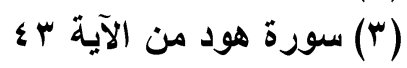

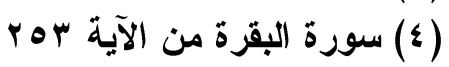

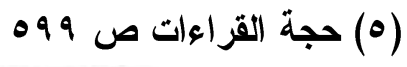




\section{الترقير الدولخ \\ ISSN 2356-9050}

4 - جميع الثواهد المذكورة كان العائد المحذوف فيها منصــوباً ، وأيضــاً كان ذلاك لكثرة الحذف في الضمير المنصوب .

V - لم يـكر أبو زرعة ضوابط حذف الضمير المنصوب وقا يكـون ذلــــ

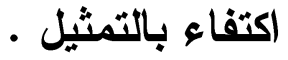

1 - اقتصر أيضاً على حذف العائد المنصوب المنصل بفعل . قضية حذف العائد على الموصول في كتب النحو : الموصولات كلها حرفية كاتت ، أو اسمية لا بـ أن تقع بعدها صلة ولا با من اثتثمال هذه الصلة على ضمير لانق بالموصول (1) فإن كان العائد مرفوعاً فلا يحذف إلَّا بشرط :

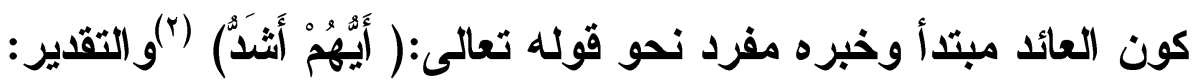
أيهم هو أثد.

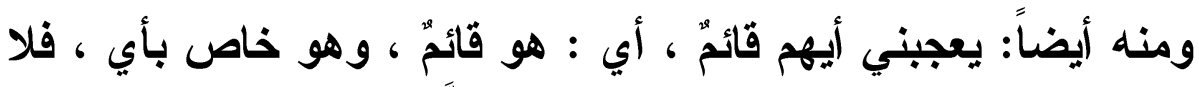

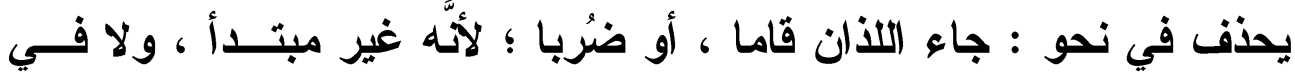
نحو: جاء الأي هو يقوم ، أو : الأي هو في الدار ؛ لأنَّ الخبر غير مفرد ؛

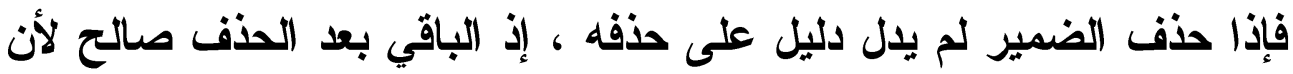
يكون صلة كاملة ، بخلاف الخبر المفرد ، كما سبق في ( أي ) ويحذف مع الأي بشرط : بون

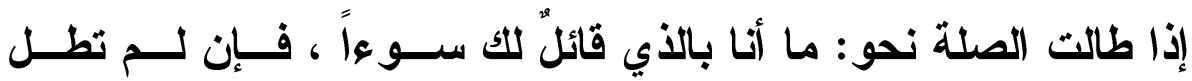

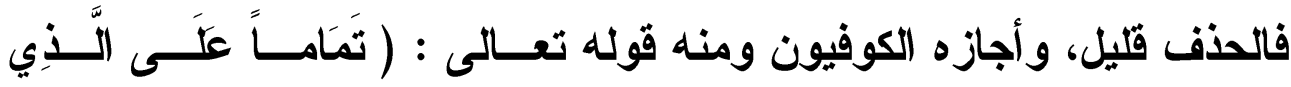

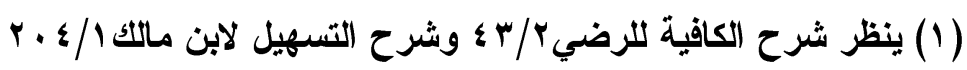

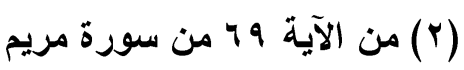



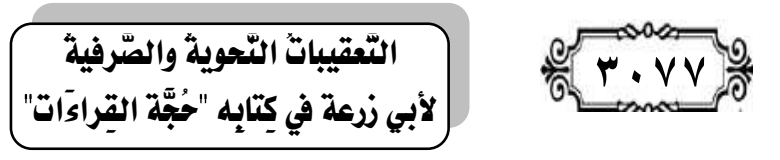

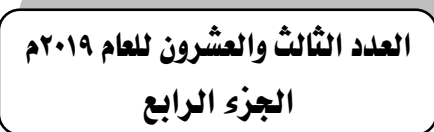

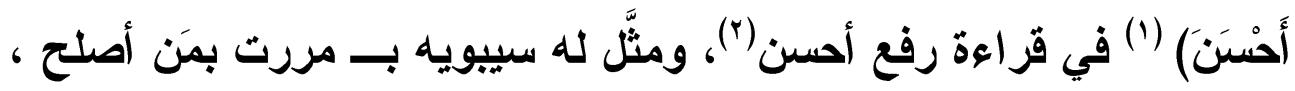

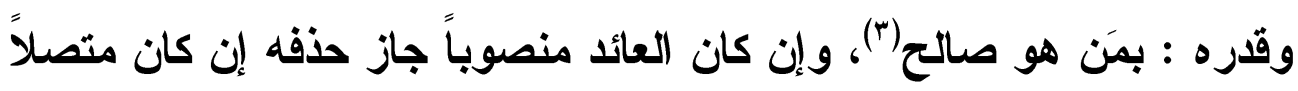

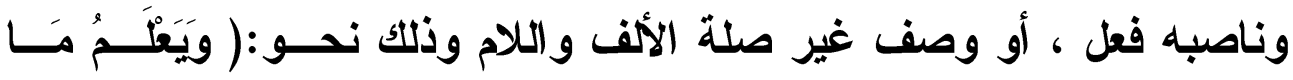

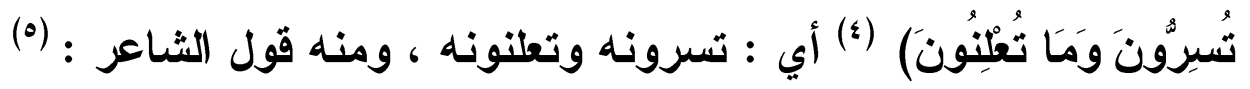

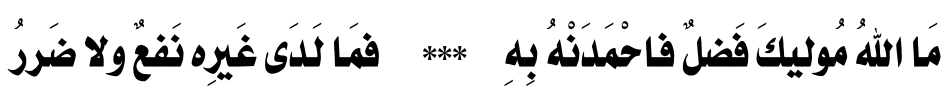

و التقدير : موليكه ، وهو من حذف العائد المنصوب بوصف وكسـان

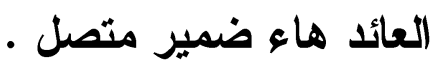
وحذف منصوب الفعل كثير" ، ومنصوب الوصف قليل" (") مثـل : الــــي معطيك زيدٌ درهم ، أي : معطيكهُ .

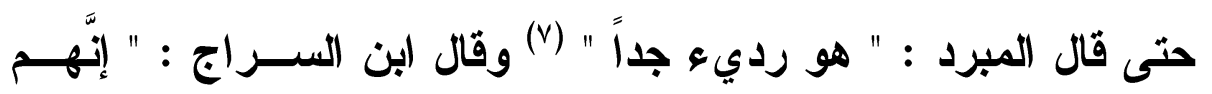

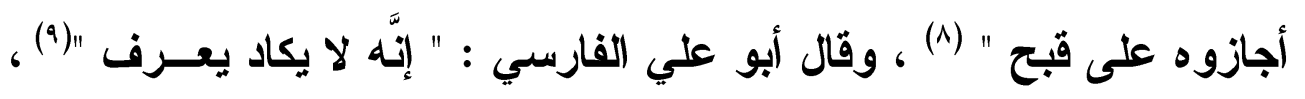

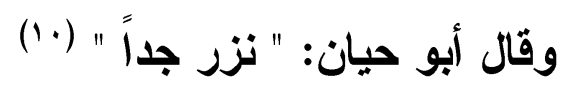

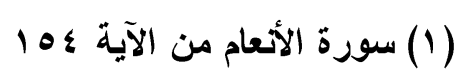

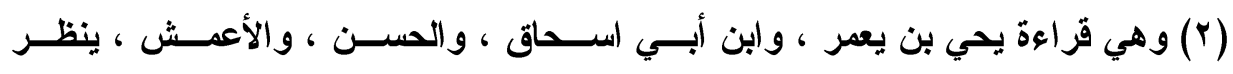

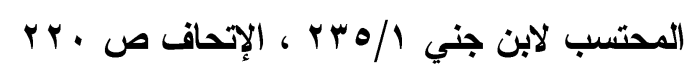

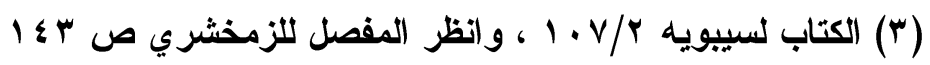

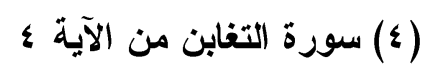

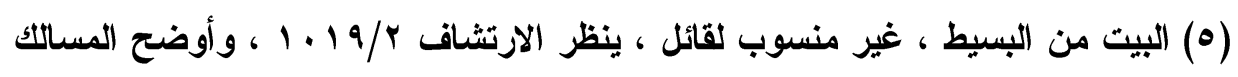

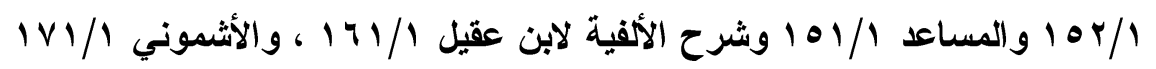

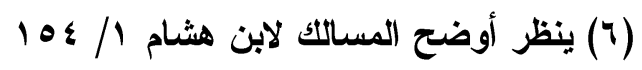

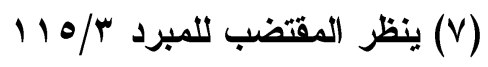

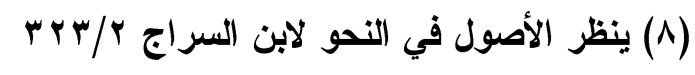

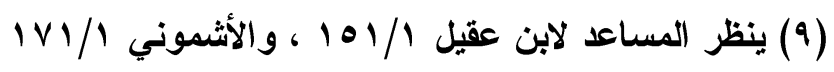

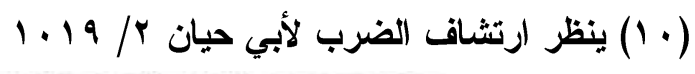




\section{الترقيم الدوله \\ ISSN 2356-9050}

أمَّا ابن ماللك فقد قال بجوازه بكثرة مثل حذف منصوب الفعل قال فـي

(1) : الأفية ابنة

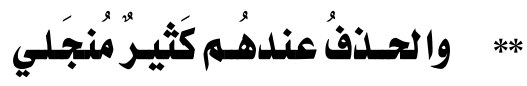

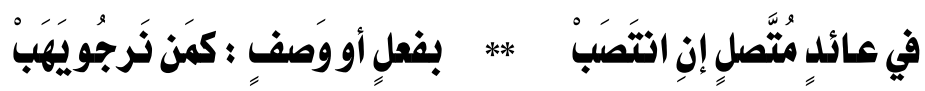

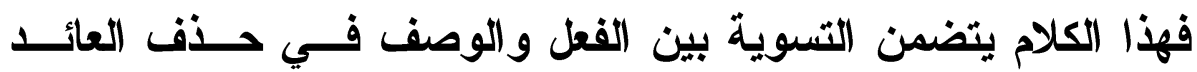

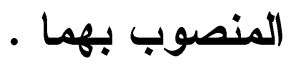

والحق كما قال ابن مالكك ؛ لأنَّ المنصوب فضلة ، والأصل في الفضلة أنَّه لا يلزم ذكره بل يجوز الاستغناء عنه في سعة الكلام . وشرط النحويون لحذف المنصوب شرطين :

أولههما : بأن لا يكون منفصلاً بعد إلَّا نحو: جاعني الأى ضربت إلَّا إيَّاه ، ولا يمنع غيره نحو: الأى أنا ضارب زيد أي : ضارب إيَّاه .

والثاني : أن يكون مفعولاً نحو: الأى ضربت زيل ، معللاً هذا بأنَّ الضــمير هنا فضلة بخلاف الضمير الأى اتصل بالحرف الناصب فلا يحذف في نحو :

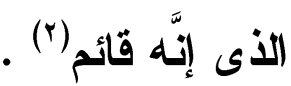

$$
\text { (1) ينظر شرح ألفية (بن مالك لابن عقيل 107/1) }
$$

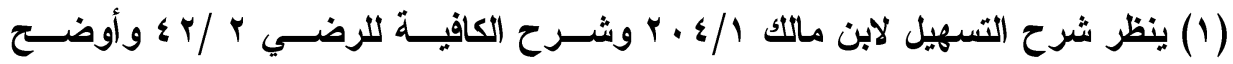

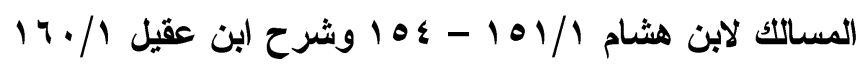



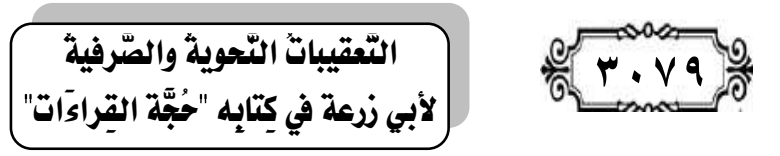

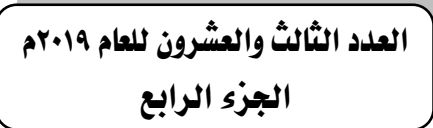

وجعل (بن مالك (1) من أمثلة حتف العائســ المنصــوب المســتوفي

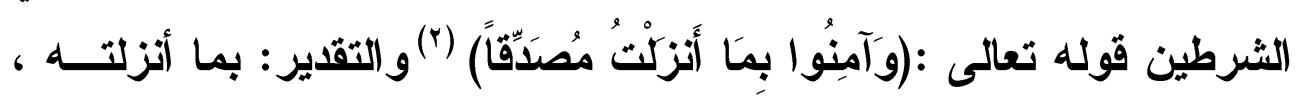

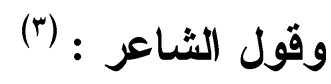

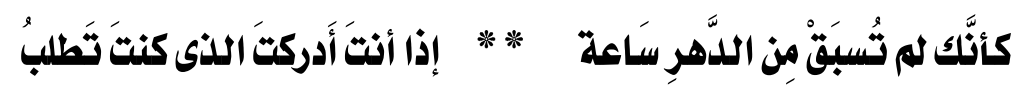

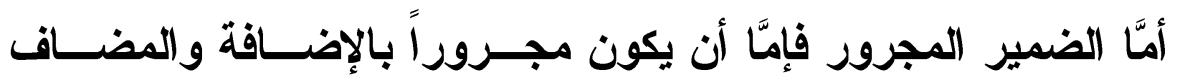

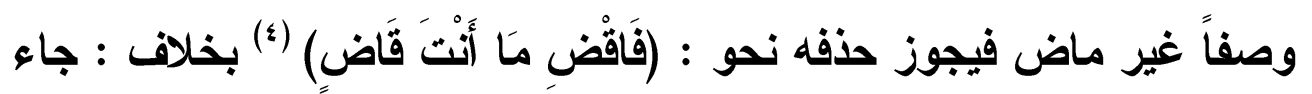

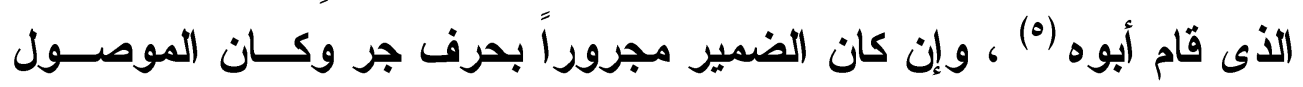

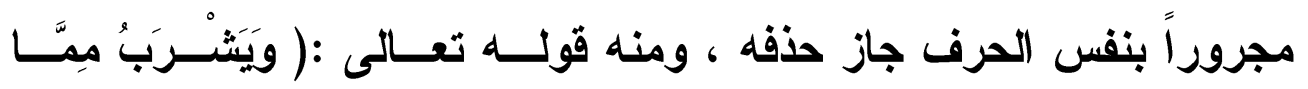

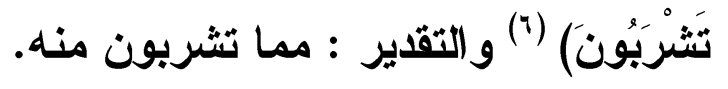

هذا ، وتعد قضية حذف الضمير العائد على الاسم الموصول قضـية

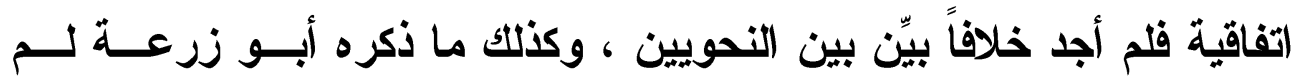

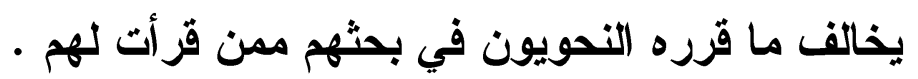

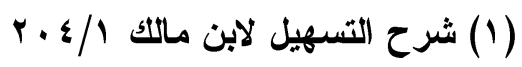

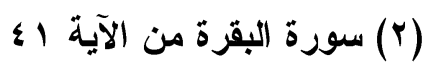

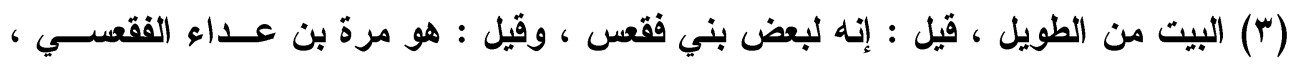

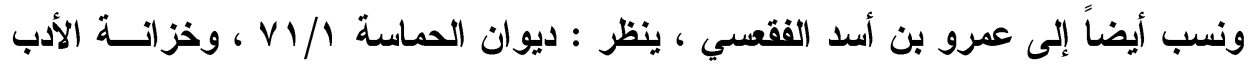

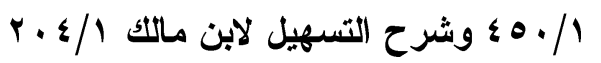

$$
\begin{aligned}
& \text { ( ) سورة طه من الآية Vr) } \\
& \text { (0) أوضح المسالك 100/1) }
\end{aligned}
$$

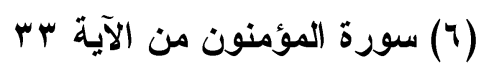




\section{الترقيم الدوله \\ ISSN 2356-9050}

\section{" لا " التي لنفي الجنس

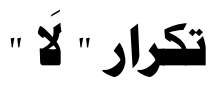

ذكر الإمام أبو زرعة رأيه في هذا الشأن في موضعين :

الموضع الأول : ثال ( اعلم أنَّ (لا) إذا وقعت على النكرة جعلث هي والاسم الأى بعدها كاسم واحد ويني ذلتك على القتح ، فإذا كررث جاز الرفع

و النصب وإذا لم تكرر فالوجه فيه القتح قال الله جل وعز: (لاَرَيْبَ فِيهِ ) (').

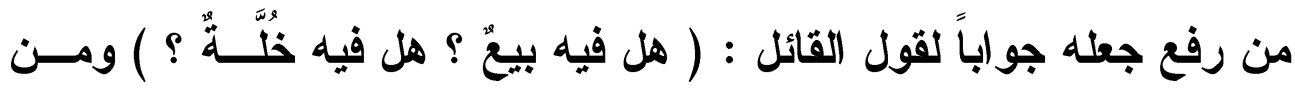
نصب جعله جواباً لقول القائل :(هل من بيع فيه ؟ هل من خلّة ؟ ) .

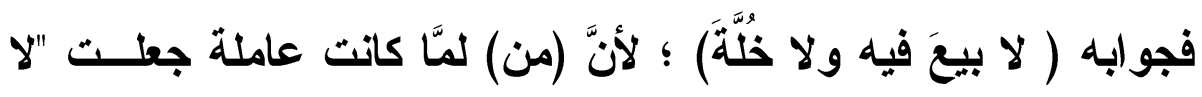

"عاملة ولمَّا كاتت جواب (هل) لم تعملها إذا كانت (هل) غير عاملة) (r) . ما تضمنه كلامه من أفكار :

ا - ذكر أبو زرعة هنا حالتين لــلا" النافية للجنس والاسم الواقع بعدها. الحالة الأولى : إذا وقع بعدها اسم نكرة ولم تكرر •

وحكمها في هذه الحالة البناء على الفتح وتصير (لا) مركبة مع اسمها تركيب أحدَ عشرَ ، وجعل منه قوله تعالى: (لآَرَيْبَ فِيهِ). 


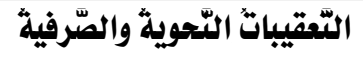

لأبي زرعة في كِتابِه "حُجَّة القِراكَاتَ"
P.1.

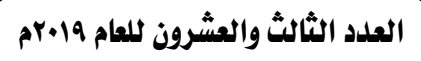

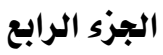

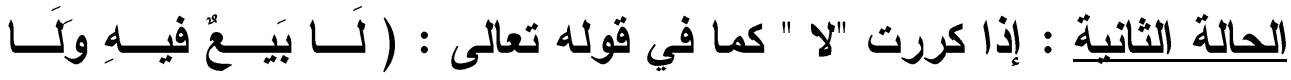

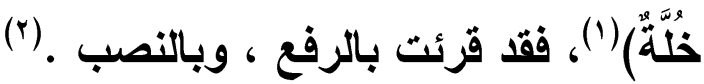
وفي الاسم الواقع بعد "لا " الأولى و المكررة وجهان :

الأول : الرفع ، ووجهه أنَّهَ وقع جواباً لــ"هل" ، وهى غير عاملة فلا تعمـل

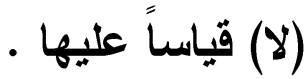

الثثاني : النصب ، وناصبه ( لا ) النافية للجنس ، ووجهه أنَّهَ جواب لقــول

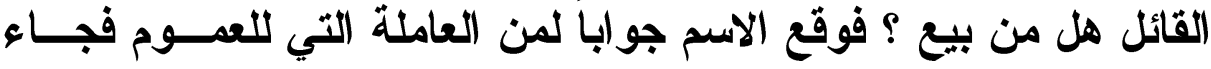

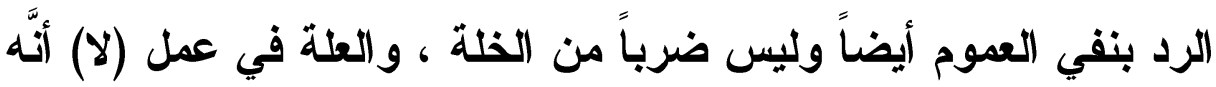

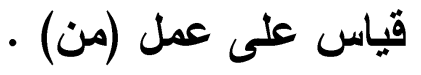
r - جاء كلام أبي زرعة في هذا التعقيب في توجيه قراعتي : الرفع و النصب

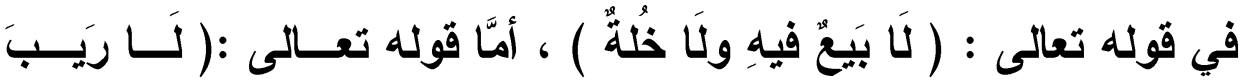

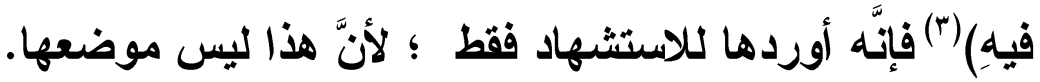

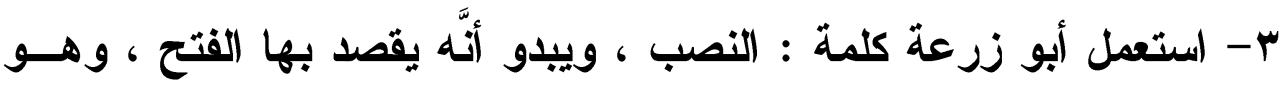

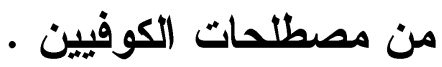

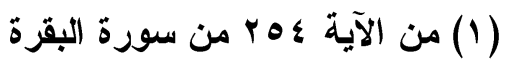

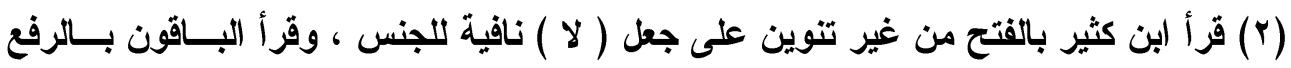

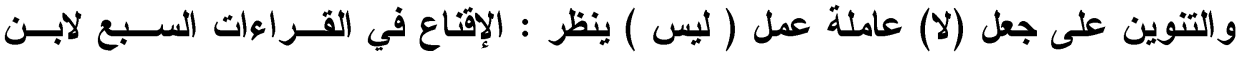

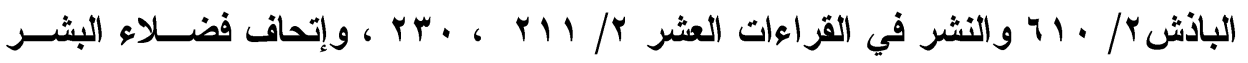




\section{الترقير الدولخ}

ISSN 2356-9050
r.Ar
حولية كلية اللفة العربية بجرجا مجية مجية مجلة علمية محكمة

الموضع الثاني : قال أبو زرعة : "واعلم أنَّ لا إذا وقعت على نكرة جعلـــ هي والاسم الأي بعدها كاسم واحد وبني ذلك على الفتح ، وإذا كررت جـاز

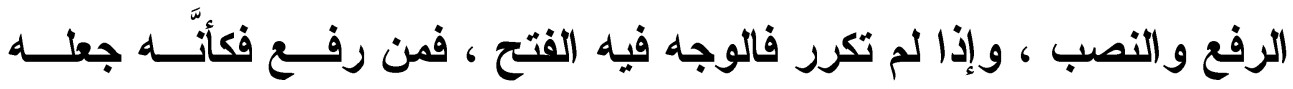
جوابا لقول القائل : أفيها لغو أو تأثيم ؟ فجطله نفياً لهذا ، ومن نصب جطله جواباً لقوله : هل من لغو فيها أو تأثيم ؟ فجوابه لا لغو فيها ولا تأثيم" (1". بيان رأي أبي زرعة في (لا) إذا كررث، والوجه الجائز في الاسم بعدها. ا - أورد أبو زرعة في (لا) حالتين ، وكان ذلك من خلال عرضه لمسـا ورد

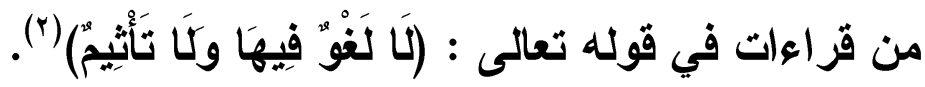

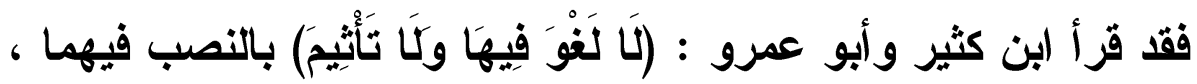
وقر أ الباقون بالرفع ().

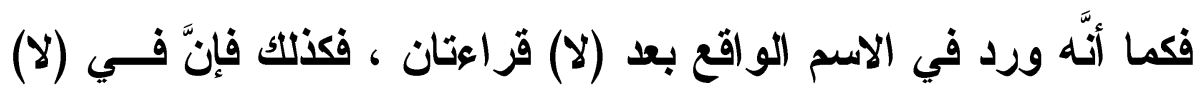
عند أبي زرعة حالتين :

الحالة الأولىى : إذا لم تكرر وكان الاسم بعدها نكرة ، فإنَّها عندائذِ تبنى مــع ما بعدها ؛ لأكَّها ركبث معه فصارتا كالكلمة الواحدة.

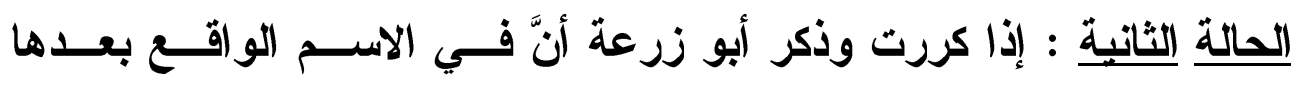
وجهين: الرفع والنصب r - اختار أبو زرعة في الاسم الواقع بعد لا غير المكررة البناء على الفتح •

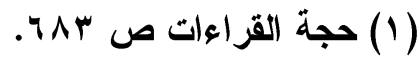

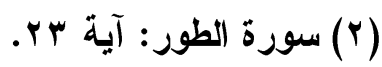

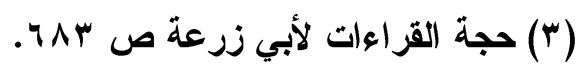




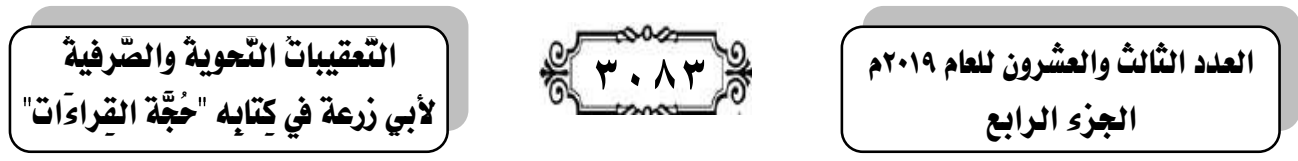

r- بيَّن أبو زرعة أنَّ في نوع (لا) المكررة ، ومعنى الكلام معها والوجسهـ المختار في الاسم بعدها فيه وجهان :

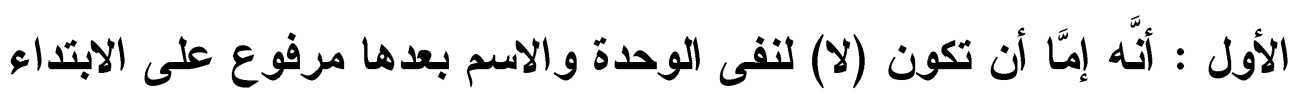

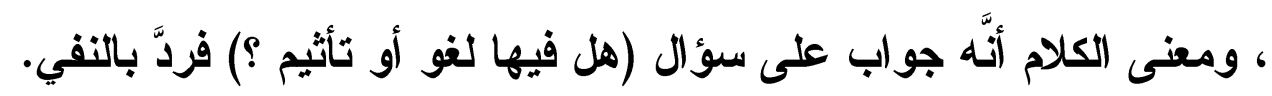

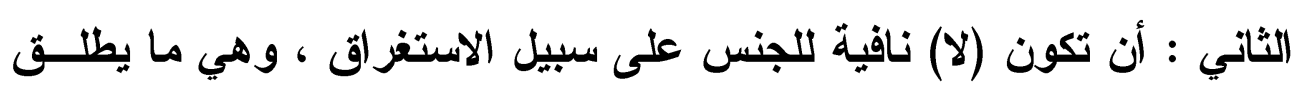

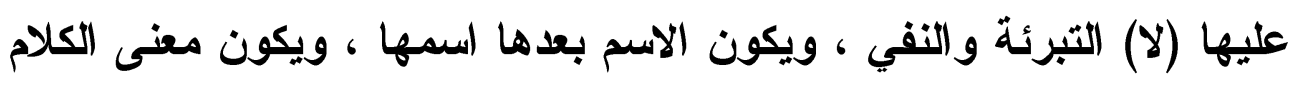

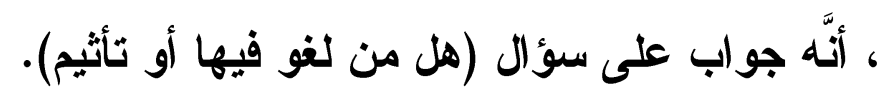

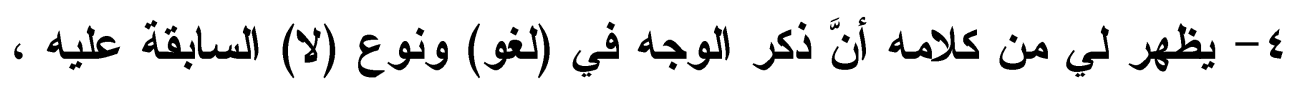

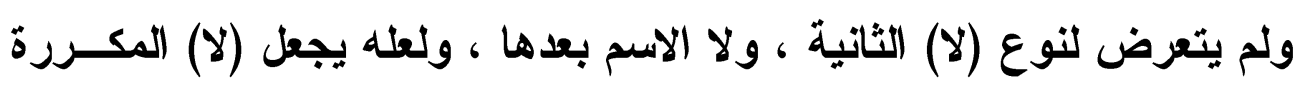
في الحكم والإعر اب كسابقتها، والاسم بعدها كالاسم الأول. تحليل ومناقشة نوع (لا) المكررة وغير المكررة وحكم الاسم بعدها . إنَّ قضية (لا) النافية للجنس وتكرارها قضية بحثت بكثرة ومتثاولة بــوفرة

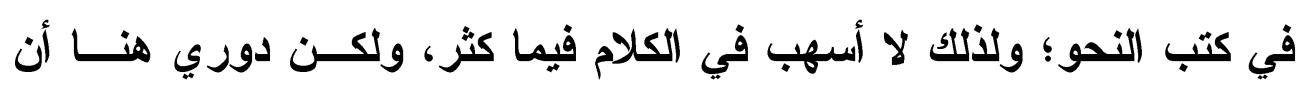
أستجلى وأستظهر الأمور الآتية لعلي أوفق في ذلك.

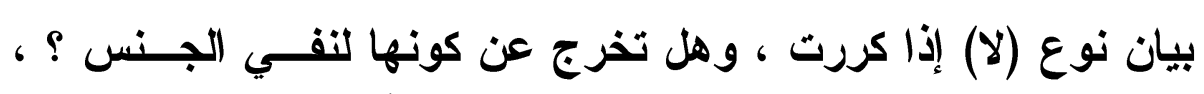

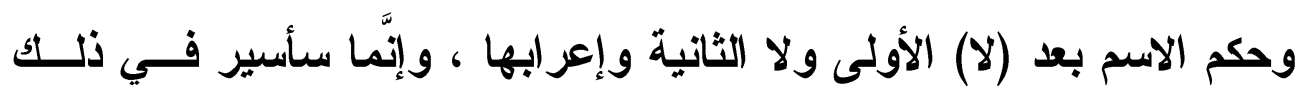

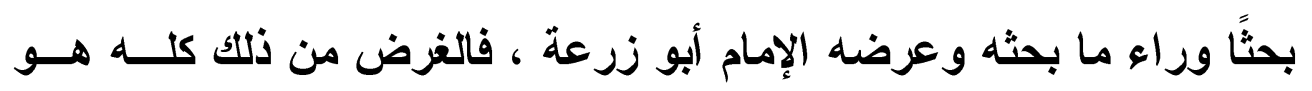

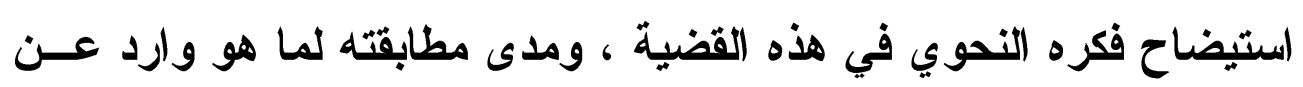
النحويين.

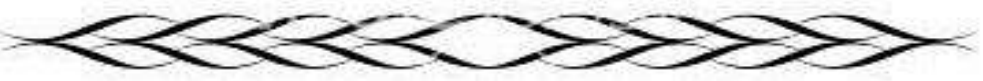




\section{الترقير الدوله \\ ISSN 2356-9050}

فالأمر عند النحويين في هذه القضية أنَّ (لا) لها حالتان : المالهة الأولى : إذا لم تكرر وقصد بها النفي على سبيل الاستغراق ، وكان

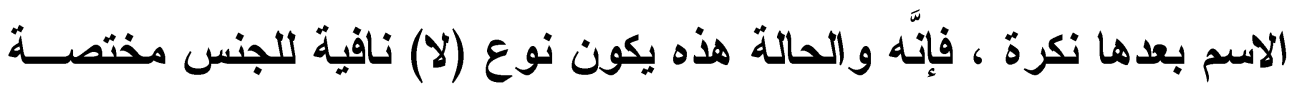
بالأسماء عملها كعمل إنَّ تنصب الاسم وترفع الخبر، هـــا إذا كــــان الاســـم بعدها مضافًا أو شبيهًا بالمضاف.

فإن كان اسمها مفردًا بني معها على القتح للتركيب(1". بيان اللمالة : وعلة النصب أو البناء على القتح في اسمها . 1 - أنَّه لو رفع لتوهم أنَّ عامله الابتداء؛ لأنَّ موضعها موضع المبتدأ . r - أنَّهُ لو رفع مع قصد التنصيص على العموم لم يحصل الغرض ؛ لأنَّهــا على ذلاك التقدير بمنزلة المحمولة على ليس ، وهي لا تنصيص فيها علــى العموم ، فلمَّا (متنع أن يعمل فيما وليها جرًا أو رفعًا - مع استحقاقها عملاً - لاختصاصها تعين أن يكون عملها نصب ما بعدها(؟).

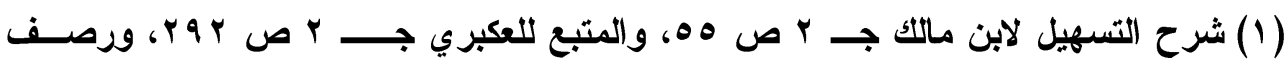

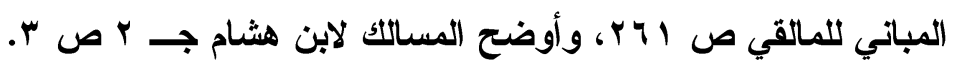

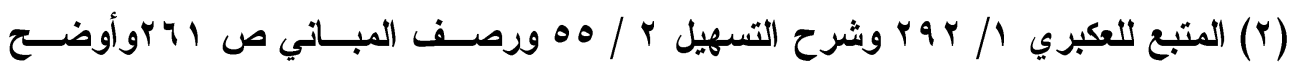

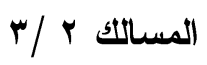


التققيباتُ التّحويثة والصّرفية لأبي زرعة في كِتابه "حُجَّة القِراءَاتَ"
\%. $r .10$

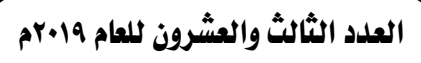
الجزء الرابع

حكم الاسم الواقع بعد (لا) من حيث البناء والإعراب :

اختلف النحويون في اسم (لا) هل هــو معـرب أو مبنــي ؟ فظـــاهر كــلام

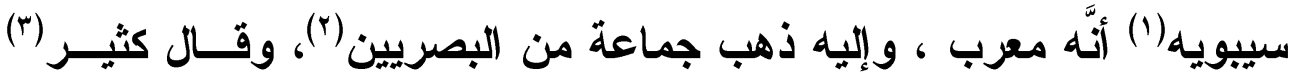

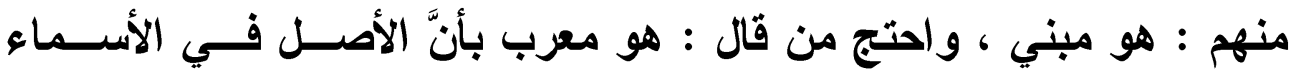
الإعزاب.

ولذلك احتيج إلى علة للبناء ولا علة هنا ، فلا بـ من إعرابه إذا كان مضافًا أو شبيهًا بالمضاف ، ولو كاتت هناك علة لاطرد في كل أحوال الاسم بعدها. ويرى آخرون أنَّ الاسم بعد (لا) النافية للجنس مبني ، وتتمثل العلــة

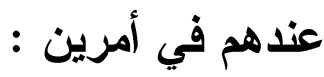
الأمر الأول : أنَّهُ تضمن معنى الحرف وهو (من). والثاني : أنَّهُ ركب مع (لا) كما ركبت خمسة عشر ، بدليل أنَّها لا تعمل إنَّا إذا

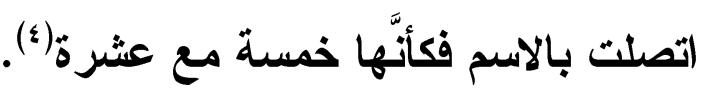

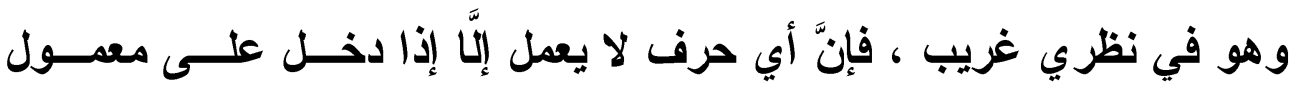
سواء كان اسمًا أم فعلاً.

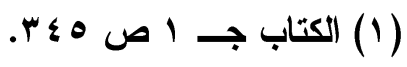

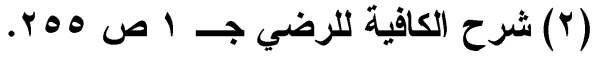

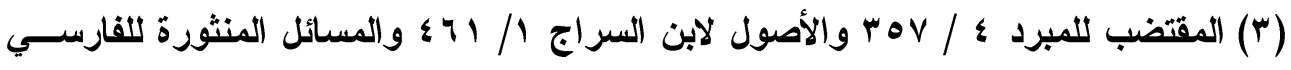

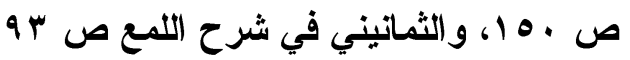
(ع) المتبع للعكبري جـ ا ص ع و هץ. 


\section{الترقيم الدوله ISSN 2356-9050}

(2)

حولية كلية اللفة العربية بجرجا

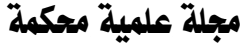

الحالة الثانية: لـ (لا) إذا كررت.

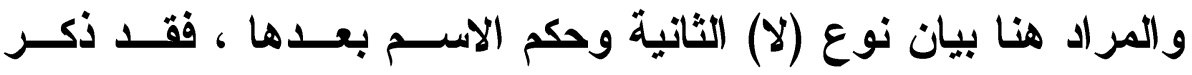

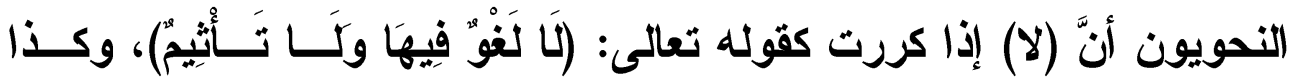

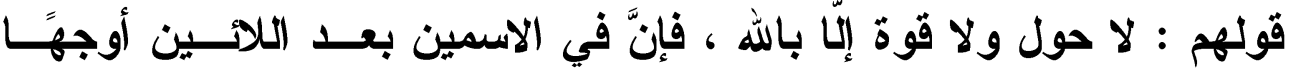

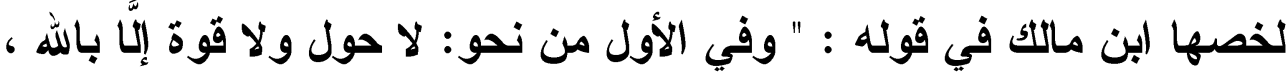

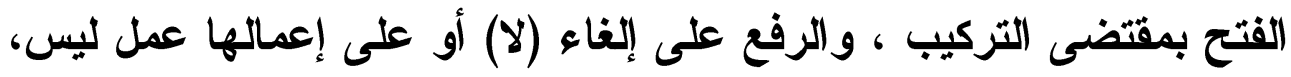
وفي الثانية عند فتح الأول الفتح بمقتضى التركيب ، وجعل الكلام في تقدير التراء

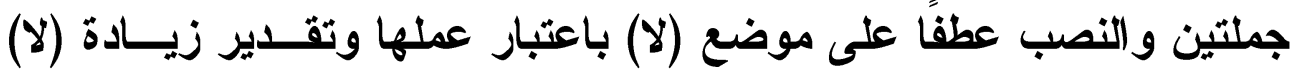

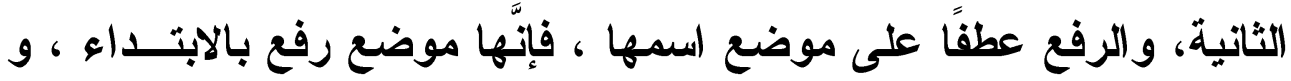

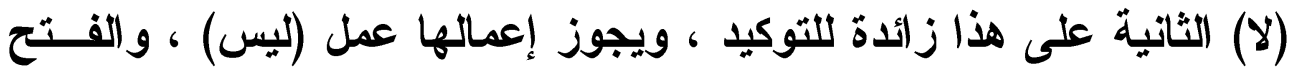
بمقتضى التركيب وجعل الكلام في تقدير جملتين " (') ولن أخفي ما انتابني من عدم الراحة حينما طالعت ما ورد في كتبـ

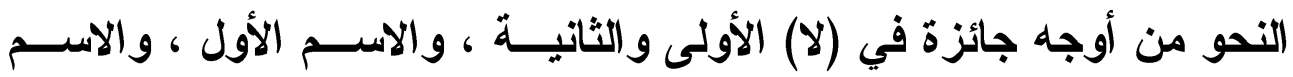

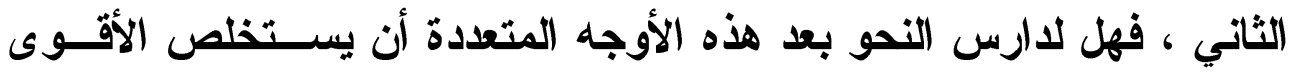

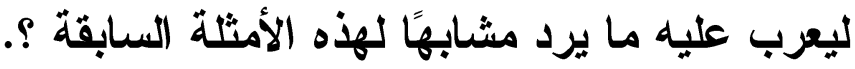

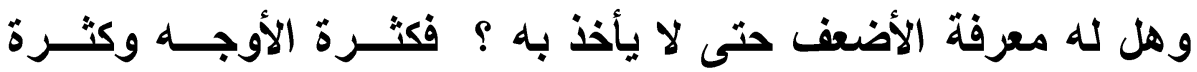

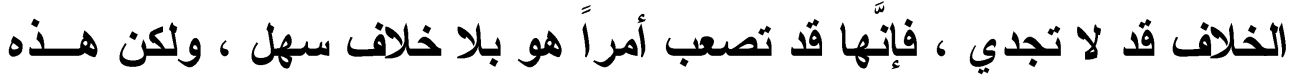
هي طبيعة العلم والعلماء، فلكل وجهة نظر ولها ما يؤيدها. وأستطيع أن أستخلص ما يبسط الأمر ويظهره في صورة غير معقدة.

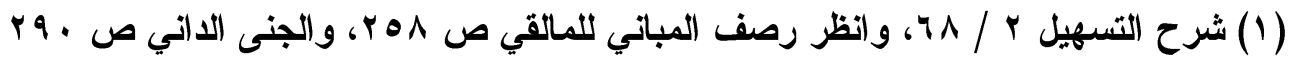

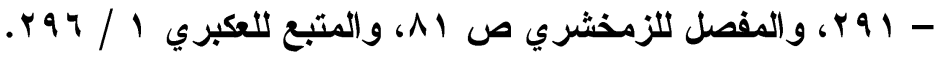




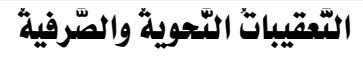

لأبي زرعة في كِتابه "حُجَّة القِراءَاتَ"

أنَّ (لا) النافية الداخلة على النكرات إن كان اسمها مفردًا ، فإنَّ من النحويين من يعملها عمل (إنَّ) فينصب بها الاسم ويرفع بها الخبـر ، ومــنهم مسن يشبهها بليس ، فيرفع بها الاسم وينصب بها الخبر. ومنهم من يجعلها لنفي الوحدة ، فالاسم بعدها مبتدأ. أمَّا عن المعنى ، فمعناها إن عمات عمل (إنَّ) النفي العام ، والعاملـــة عمل (ليس) النفي الخاص.

وعلى حسب المعنى يكون نوع ووجه إعراب الاسم بعدها متوقف عليها (')

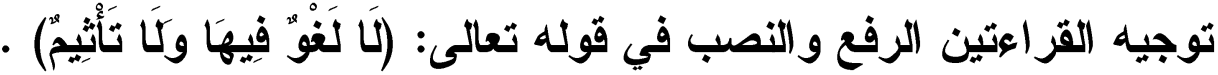
الرفع على أنّ (لا) الأولى نافية للوحدة ، والاسم بعـدها مبتـــأ ، ولا

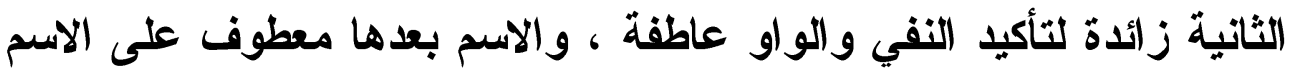

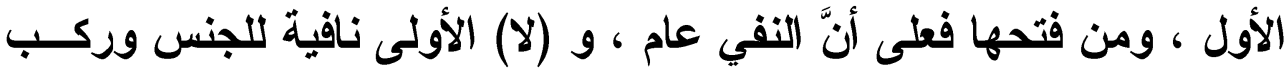
الاسم معها فبنى على الفتح.

و (لا) الثانية واسمها مثل (لا) الأولى واسمها و الواو عاطفة(؟).

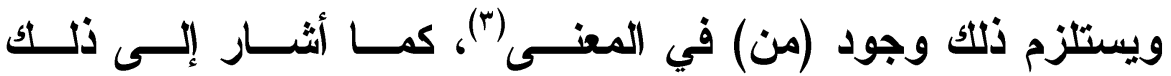
أبوزرعة() في تقدير معنى الكلام على هذا الوجه في الآية.

(1) (1) رصف المباني ص بآY.

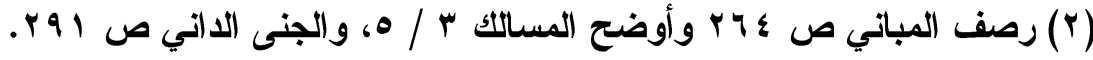

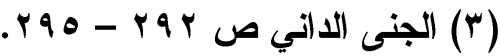

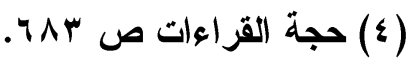




\section{الترقير الدولم \\ ISSN 2356-9050}

\section{بنضح مما سبق بعض الأمور أهمها :}

الأمر الأول : ( لا ) التي لنفي الجنس هي العاملة عمل " إنَّ " إذا أريد

بها نفي الجنس على سبيل التنصيص ، وتسمى حينئ ( لا ) التبرئة وهى لا تعمل إلَّا في النكرات واسمها إذا لم يكن عاملاً فإنَّهُ يبنى لتضمنه معنى (من) الاستغز اقية ، أو لتركيبه مع " لا " تركيب خمسةَ عشرَ وصـيرورتهه معهــا كالثيء الواحد وبناؤه على ما ينصب به إذا كان معرباً (1) يقول سيبويه : ( ولا تعمل (لا) إلَّا في النكرة تجعل معهــا بمنزلــة :

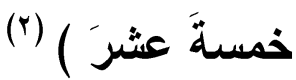

الأمر الثاني : أنَّ اسم (لا) مختلف فيه بين الإعـــراب والبنـاء علــى مذهبين الأول : أنَّه معرب ، وبه قال سيبويه (זّ)، وبعض البصريين لعدم وجود

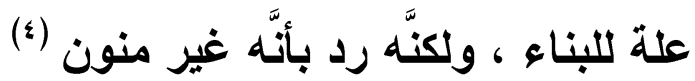
الثاني : أنَّهُ مبني لتضمنه معنى الحرف وهو : من .

(1) ينظر المفصل للزمخشري ص V9 و شرح التسهيل لابن مالكا r / ro و مغني اللبيب

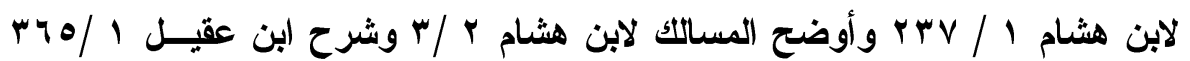

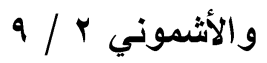

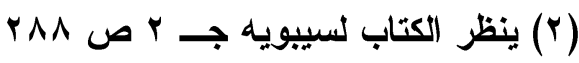

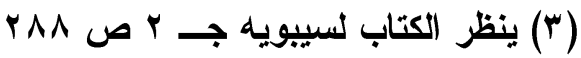

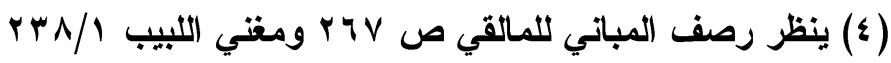


التققيباتُ التّحويثة والصّرفية

لأبي زرعة في كِتابه "حُجَّة القِراءَاتِ"

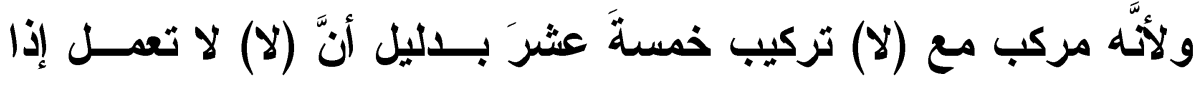

انفصت عن اسمها ونسب هذا المذهب إلى الكوفيين (1)

فمن قال بالبناء فإنَّهَ يينى على الفتح في مثل :لا رجلَ ولا رجالَ ـ إذا كــان

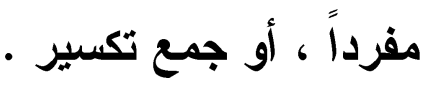

وينى على الياء في المثنى نحو: لا رجلين ـ وعلى الكسرة في جـــع

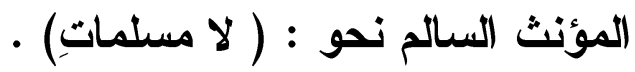

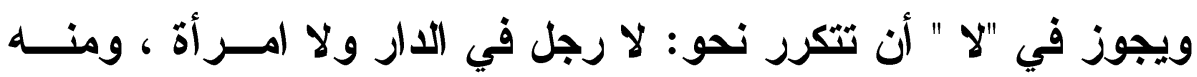

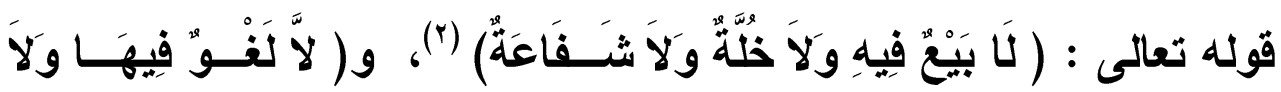
(ॅ)

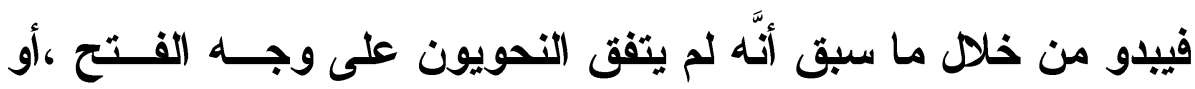

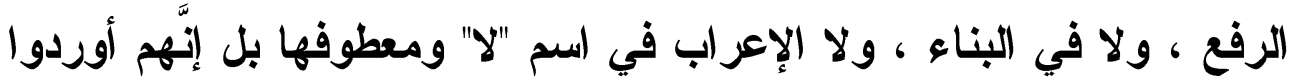

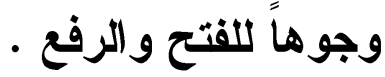

الأمر الثالث : لم أجد من النحويين - مما اطلعت عليـهـ - مـنـ أورد

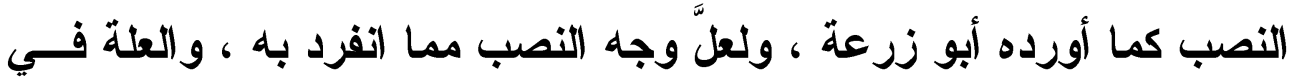

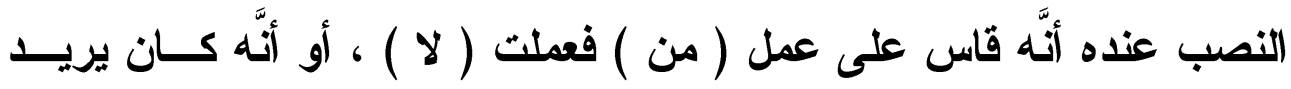

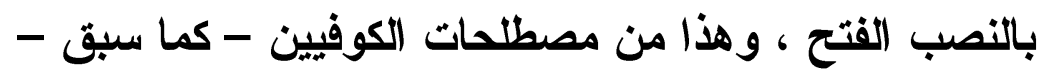
كما أنَّ هذه المسألة تكاد تكون من مواضع التكرار عنده ، وقــــــــــ

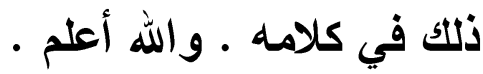

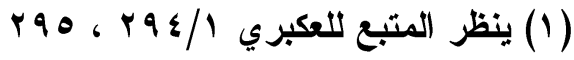

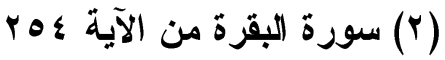

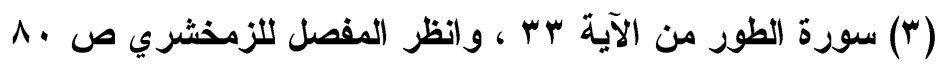




\section{الترقير الدولم \\ ISSN 2356-9050}

Q

حولية كلية اللفة العربية بجرجا مجلة علمية محكمة المية

\section{باب الفَاعل}

\section{تأَنِيث الفِعل وتَذكِيره إذا كان الفَاعل اسمَ جَمَهع}

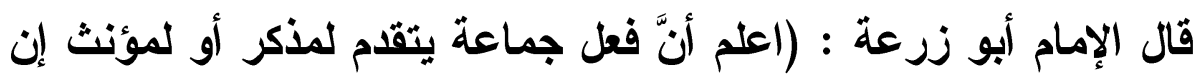

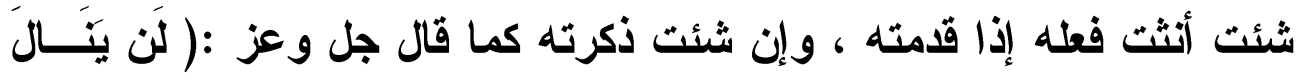

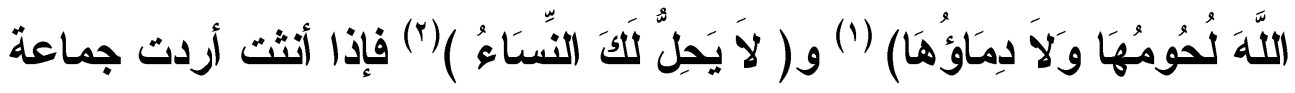

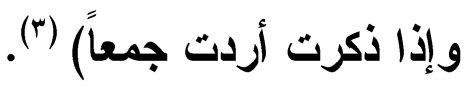

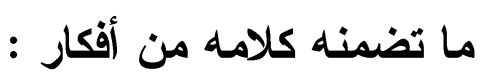

1- ذكر أبو زرعة هنا قاعدة تتعلق بتأنيث الفعل وتذكيره إذا كـان فاعــهـ

جمعاً أو اسم جمع وكان الفاعل مؤخراً.

r- استثه أبو زرعة بمثالين من القرآن الكريم :

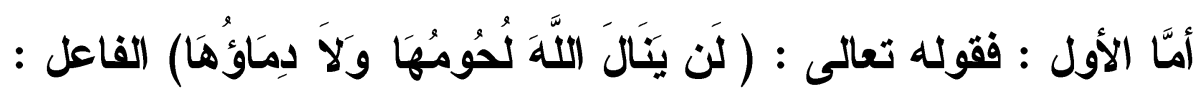

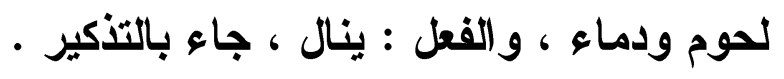

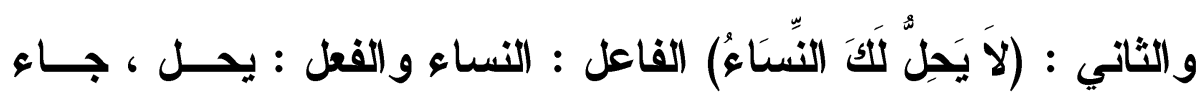

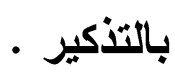

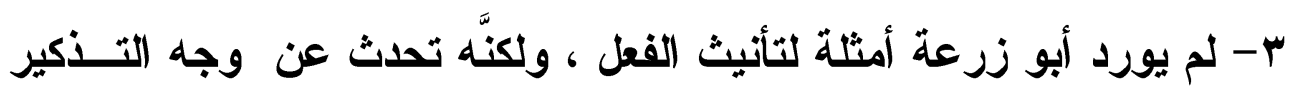

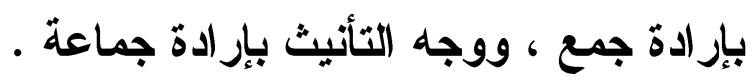

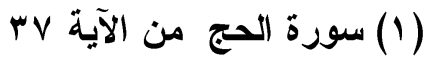

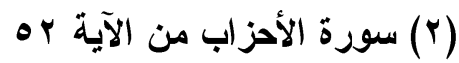

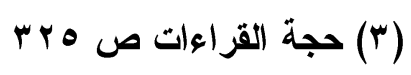


التققيباتُ التّحويثة والصّرفية

لأبي زرعة في كِتابه "حُجَّة القِراءَات"
\%.

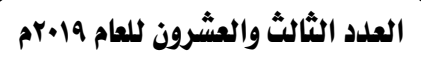

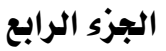

وأذكر هنا أنَّ من أحكام الفاعل أنَّه إذا كان مؤنثاً أنث له الفعـل بتــــاء ساكنة في آخر الماضي ، أو بتاء متحركة في أول المضارع .

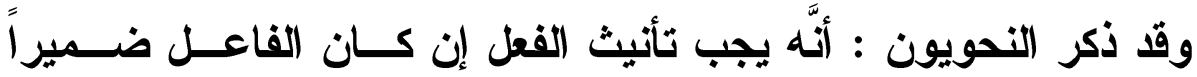

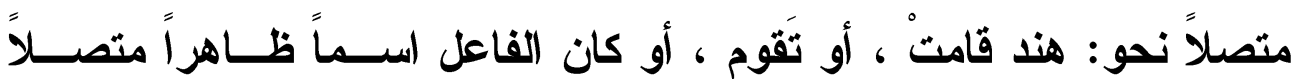

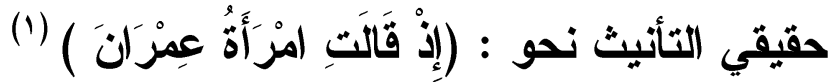
ويجوز تأنيث الفعل وتذكيره في مسألتين :

أولهها : إذا كان العامل اسماً ظاهراً منفصلاً عن فعله نحـــو: حضــر

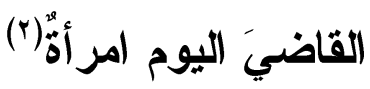

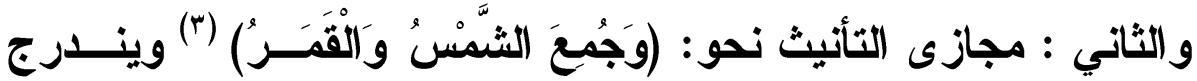

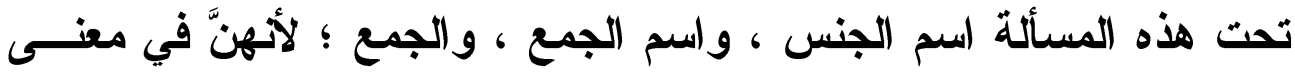

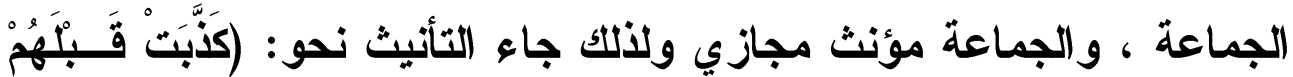

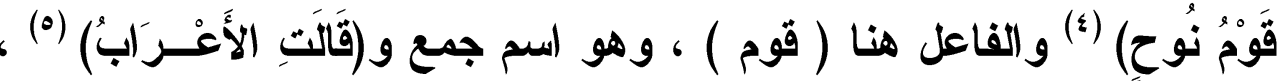
والفاعل هنا ( الأعراب ) ، وهو جمع تكسير •

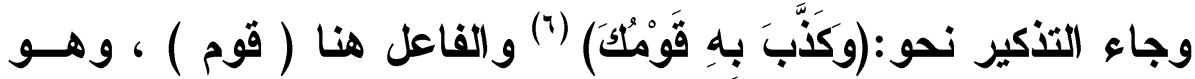

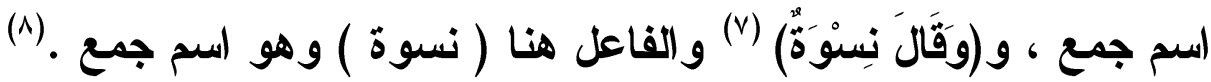

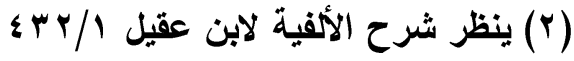

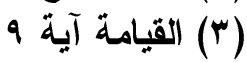

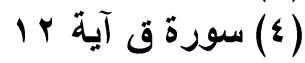

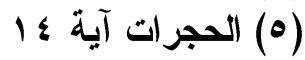

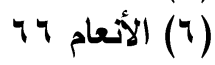
r. يوسف (V) (V)

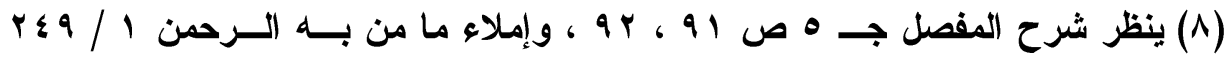

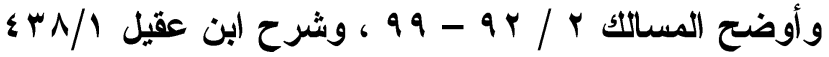




\section{الترقيم الدوله \\ ISSN 2356-9050}

وعلى ذلك فإثبات التاء لتأوله بالجماعة وحذفها لتأوله بالجمع (1)

قال العكبري :( و إنَّما ساغ ذلاغ حمــلاً علــى المعنــى ؛ لأنَّ الجمــع

والجماعة بمعنى واحد)(بال)

ولكون تأنيث الفعل وفاعله جمع مؤنث بالتأويل على معنى جماعــة ،

وجعل الرضي حذف العلامة فيه أولى من حذفها مع المفرد(ب)

هذا ولم أجد بين النحويين خلافاً يذكر في هذه المسألة فهـي مســألة

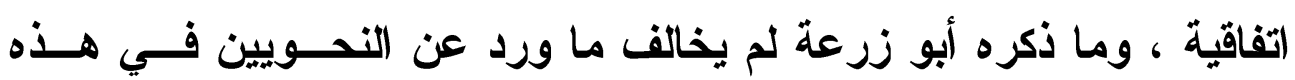

المسألة 
التققيباتُ التّحويثة والصّرفية لأبي زرعة في كِتابه "حُجَّة القِراءَاتَ"
क.

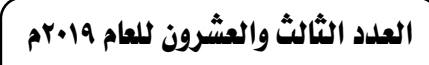

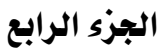

\section{باب الاشتغال}

\section{إعراب الاسم المتقدم إذا ذكر ضميره وإعرابه إذا لم يذكر الضمير.}

قال أبو زرعة في التعقيب على قر اعتي الرفع و النصب في قوله تعالى:

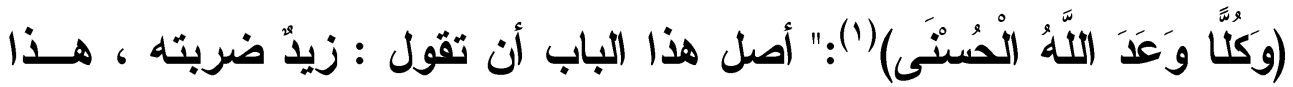

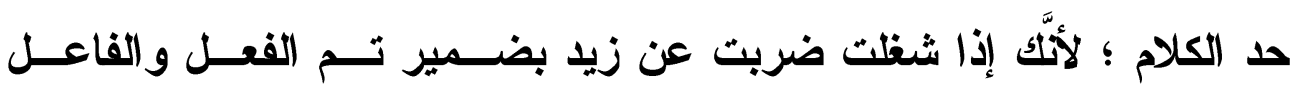

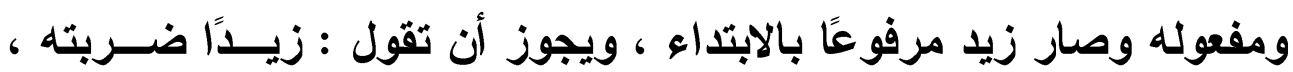

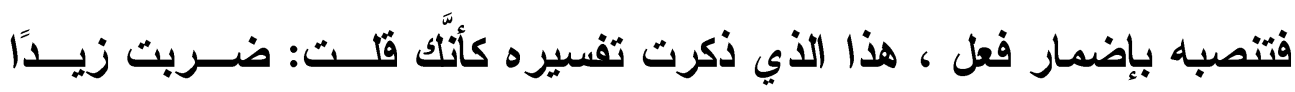

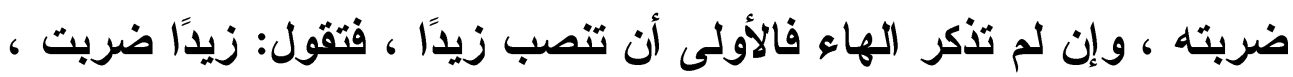

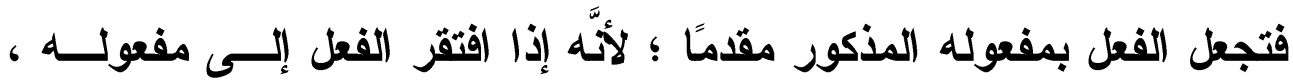

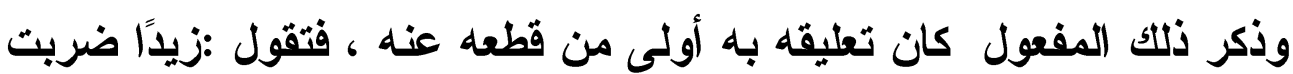

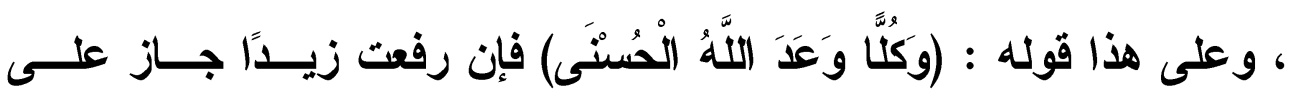

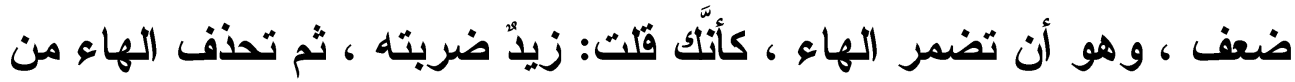

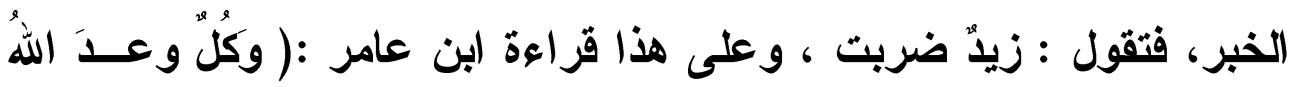

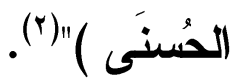

ما تضمنه كلام أبي زرعة : أورد لنا أبو زرعة مثالين ، وفي كل مثال ذكر وجهين. المثنالان هما : (زيدٌ ضربته) بالهاء ، و (زيدّ ضربت) بدون هاء. المثال الأول : (زيدٌ ضربته) هو من باب الاشتغال ، وفيه وجهان :

(1) سورة الحديد آية ـ ـ قرأ ابن عامر بالرفع ، وقرأ الباقون بالنصب حجة القراءات لأبسي

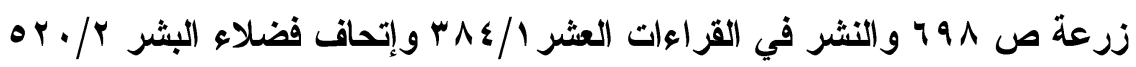

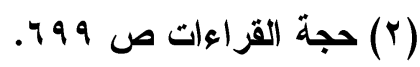

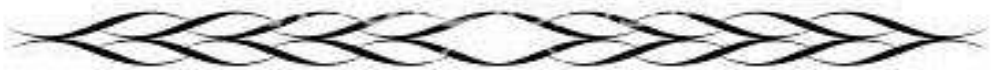




\section{الترقير الدولخ \\ ISSN 2356-9050}

الوجه المختار الرفع على أنَّه مبتدأ ، والجملة المكونــة مــن الفعـل والفاعل والمفعول في محل رفع خبر، هذا حد الكلام عند أبي زرعة.

الوجه الثاني : الجائز النصب على إضــــار فعـل محـــوف يفســره المذكور، والمعنى: ضربت زيدًا ضربته ، وهو داخل أيضًا في باب الاثتغال. المثال الثاني: (زيدٌّ ضربت) بدون ضمير في الفعل وفيه وجهان :

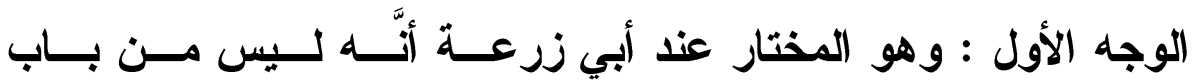

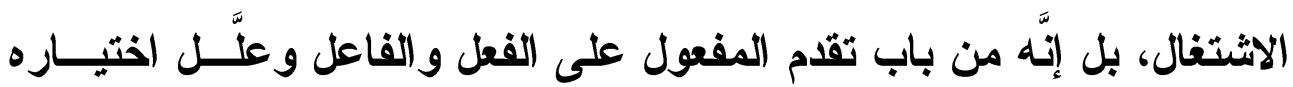
بأنَّه لا حاجة معه إلى التقدير والتأويل ، فلا حاجة لتقدير شيئين ضمير فـي الفعل ليكون مفعوله ، ولا حاجة لتقدير (فعل) قبل زيل لينصبه ، فــ(ضربت) تحتاج مفعول وزيد يحتاج فاعل، فلا داعي لقطع الفعل عــن مفعولــه مــع وجوده.

الوجه الثاني : وقد حكم أبو زرعة بضعفه ، وهو اعتبار (زيا ضربت) من باب الاثتنغال على حذف ضمير المفعول في الفعـلـ ، و(زيــــ مبتــــأ ،

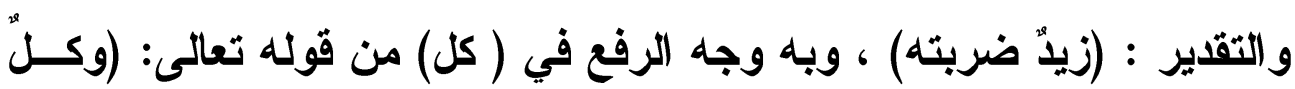
وعدَ اللهُ (الحسنحى). اختبار ات النحويين في إعراب الاسم في الحالتين السابقتين: الحالة الأولى : وهي الاخلة في باب الاثتغال ، وهي: (زيدٌ ضربته)، فزيد المشتغل عنه و(ضرب) الفعل المشغول ، والهاء الضمير المشتغل به. وفي الاثتغال أحوال كثيرة ، وأوجه في الاسم وفقًا لكل حالة. 


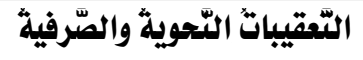

لأبي زرعة في كِتابِه "حُجَّة القِراكَاتَ"
P.90

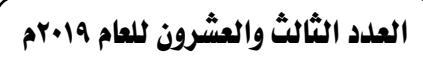

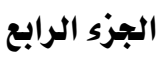

ولكن مقتضى البحث أن أسلط الضوء فقط على الحالة التي ذكرها أبو

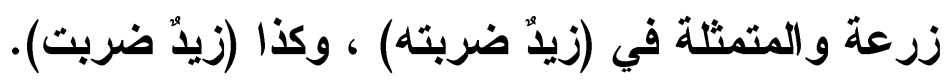
وفي (زيدُ ضربته) عند النحويين وجهان : الرفع ، وهو المختار، وقد

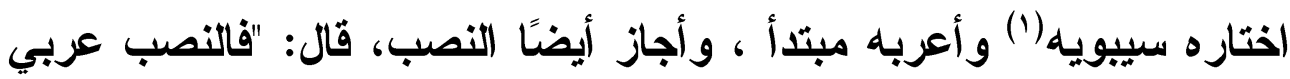

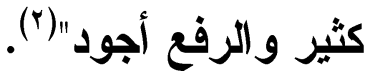

أمَّا في (زيدًا ضربت) بدون ضمير، فقد اختار النصب ، ورجحه بقوله:

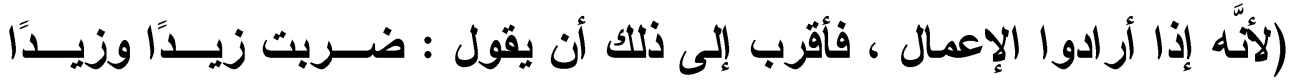

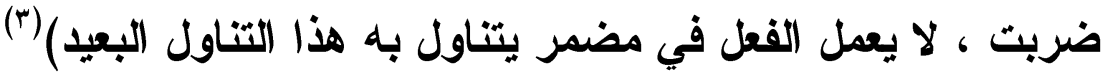
فــ (زيدًا) عنده مفعول مقدم ، و الفعل بعده عمل فيه ، وقــــ (سـتبعد عدم إعمال الفعل في الاسم المنصوب قبله. هذا عن رأي سيبويه في الحالتين :

أمَّا المبرد فقد اختار في (زيدًا ضربته) النصب على الاشتغال بأن يكون

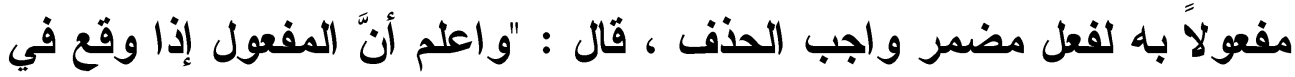
مثل هذا الموضع ، وقد شغل الفعل عنه انتصب بالفعل المضمر؛ لأنَّ الـــي

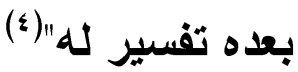

$$
\begin{aligned}
& \text { (1) (الكتاب جـ I ص זم. }
\end{aligned}
$$

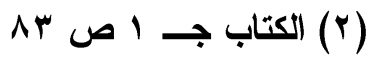

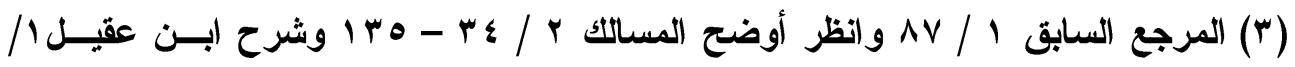




\section{الترقير الدولخ \\ ISSN 2356-9050}

وهو ما اختاره أيضًا الزمخشري ، وعلل منـع إظهار الفعـل المضــمر

بأنَّه استغتاء عنه بتفسيره(')

وهو ما اختاره أيضًا ابن مالك ، وعلل عدم جواز ظهور الفعل المضمر

بأنَّ الفعل المذكور بمثابة العوض عن المضمر ، فكما لا يجمع بين العـوض هـ

والمعوض عنه ، لا يجمع بين الفعل ومفسره(؟) ، وعليه أكثر النحويين(؟).

أمَّا : زيا ضربت ، وفيه تقدم اسم وتأخر فعل لم ينشغل بضميره عنه،

فالمختار فيه النصب على أنَّهُ مفعول مقدم للفعل المذكور، ولكنَّهم اختلةــوا

في جواز حذف الضمير(ء).

ذلك أنَّهم اثشترطوا في باب الاشثتال وجود ضمير يكون هو العلاقة بين

العامل و الاسم السابق.

ويمكن أن يكون أيضًا ضميرًا منفصلاً ، نحو: (زيــدًا مــررث بــه)،

أو باسم مضاف ، نحو: (زيدًا ضربت أخاه) ، أو باسم أجنبي فيــه ضـمير،

نحو: (زيدًا ضربت عمرًا وأخاه)(ه).

وحيث لا يوجد في (زيدًا ضربت) أحد هذه الأثياء ، فإنَّ هذه الحالــة

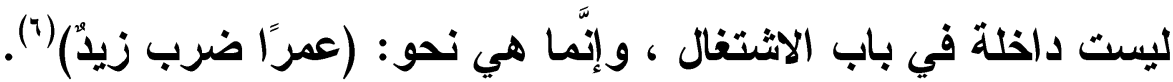

(1) المفصل ص 9 ؛ـ.

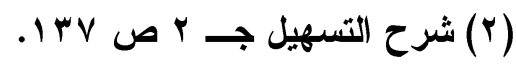

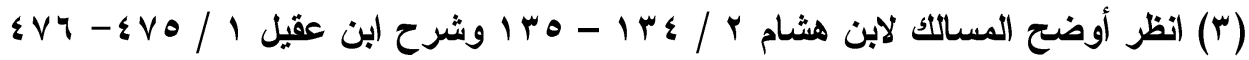

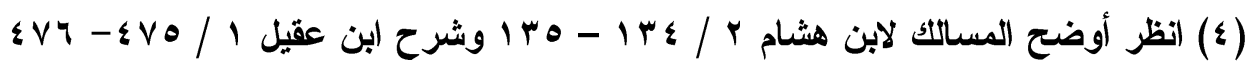

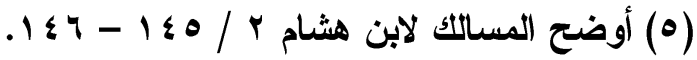

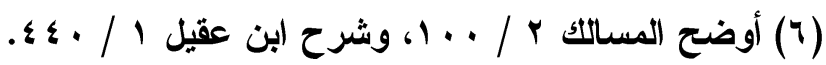


التّقيباتُ التّحوية والصّرفية

لأبي زرعة في كِتابه "حُجَّة القِراءَاتِ"
r.9V

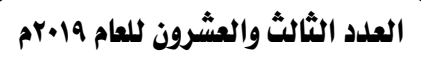

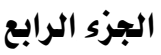

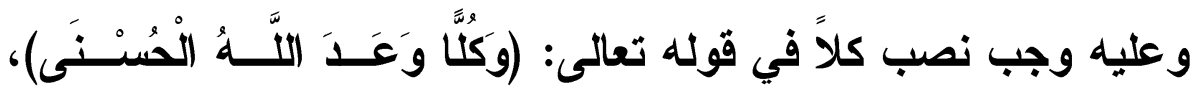
ونصب زيدًا في : (زيدًا ضربت) ، وهو ما اختاره أبو زرعة.

بينما يرى بعض النحويين ، ونسبه أبو حيان (1) إلى الفراء أنَّهَ من باب الاشتغال على حذف ضمير في الفعل ، ولكن خص حذفه بالضرورة ، وجعل

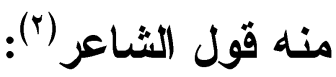

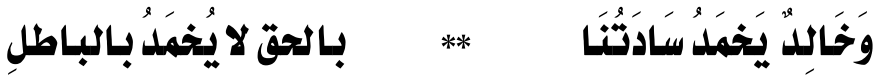

فــ(خالد) رفع ، و الفعل بعده (يحمد) حذف منــه ضــمير المفعـول ،

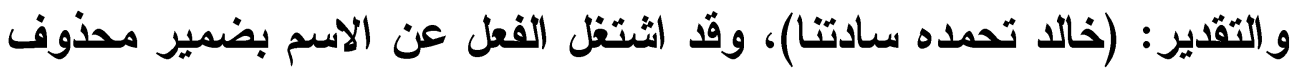

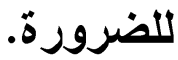

وبه قال (بن الأبباري(")، ولكنَّه حكم على هذا الحذف بالقلة في اختيار الكلام مع جوازه قال: (وإن كان هذا الحذف قليلاً في اختيار الكلام)(؛).

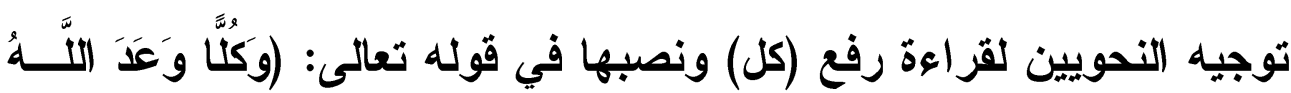
(الْحُنَْى). ذكر ابن الأبباري(0) أنَّ نصب (كلاً) على أنَّهـه مفعول أول مقــدم للفعـل (وعد)، فليس من باب الاشتغال ، و (الحسنى) مفعوله الثاني.

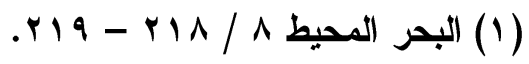

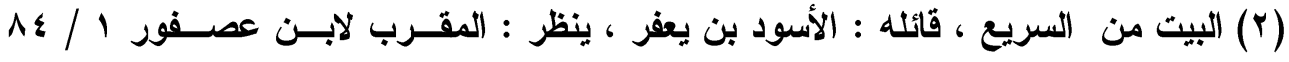

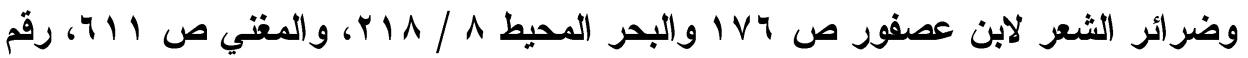

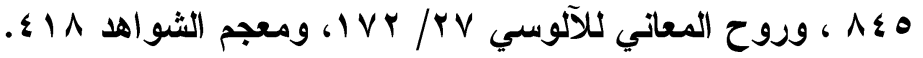

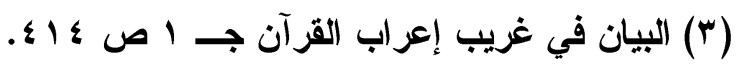

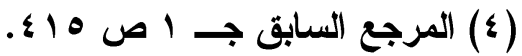

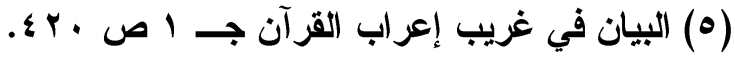




\section{الترقيه الدولم \\ ISSN 2356-9050}

أمَّا الرفع فهو عنده على وجهين :

الأول : أنَّه مبتدأ ، وجملة (وعد) خبره ، وقدر في (وعد) هاء.

الثاني : أن يكون خبر لمبتدأ محذوف تقديره : (أولئك كل وعد الله) ، وجملة

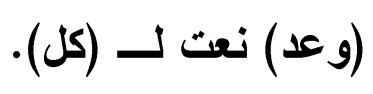

ووافقه العكبري (1) في وجه النصب فنكر أنَّ معمولها مفعولان :

$$
\text { الأول : مقدم وهو (كلاً) والثاني : (الحسنى). }
$$

ووافق أبو حيان (ז) (بن الأبباري في رفع (كل) ، والظاهر عنــده أنَّـها مبتدأ ، والجملة بعده في موضع الخبر، ونسبه إلى الفراء وهشام.

ونقل أبو حيان عن البعض وجهًا آخر للرفع ، وهو أن يكـون (كـلـ) خبر لمبتدأ محذوف ، والتقدير : (أولئك كل) ، وجملة : (وعد) نعت ، ولعله يقصد ما ذكره ابن الأبباري في الرفع. وعلل أبو حيان اختيارهم إعراب جملة : (وعد) نعتًا أنَّ حذف العائــــ

من جملة النعت أكثر من حذفه من جملة الخبر(r). ولعل القارئ يلحظ أنَّ جميع ما سبق مــن أوجـــه تبنـاهـــا النحويــون ووجهوا بها القراعتين ، هي ما ذكرها أبو زرعة بالتصريح تارة ، وبالتمثيل أخرى مع الإيجاز في كل ما ذكر. 
التققيباتُ التّحويثة والصّرفية لأبي زرعة في كِتابه "حُجَّة القِراءَات" r.9.9.

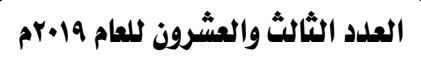
الجزء الرابع

\section{باب المتعدي واللازم}

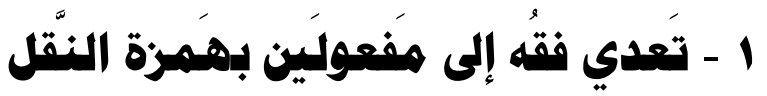

قال الإمام أبو زرعة :(واعلم أنَّ ( فَقَهْتُ) فعل يتعدى إلى مفعول تقول:

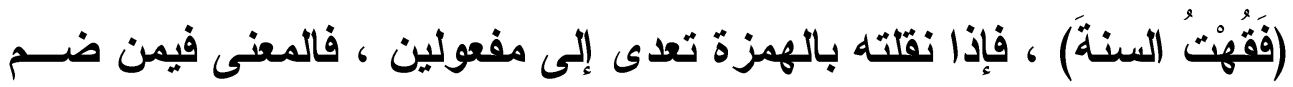

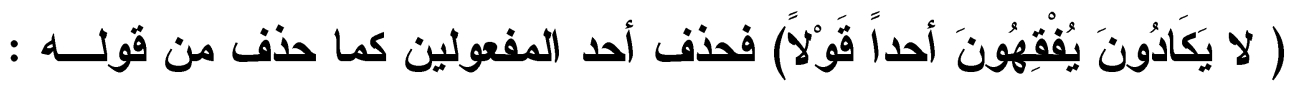

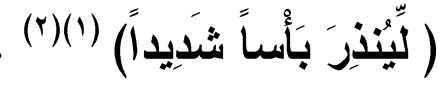

$$
\begin{aligned}
& \text { توضيح كلام أبى زرعة : }
\end{aligned}
$$

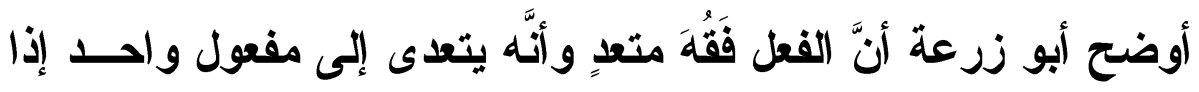

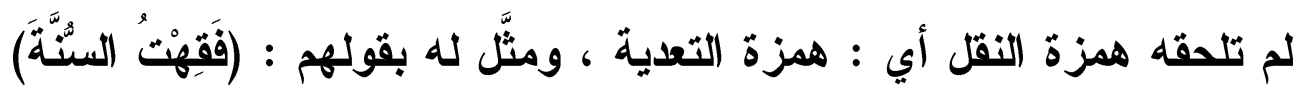
فالسنة مفعول لفقهت.

ويتعدى إلى مفعولين بالهمزة وجعل منه قوله تعــالى:( لَــا يَكَادُونَ

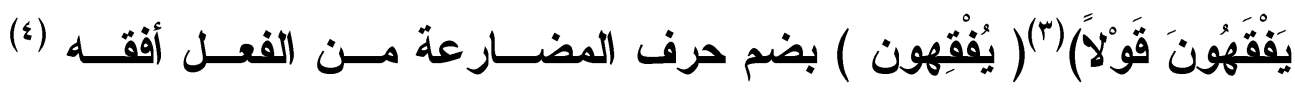

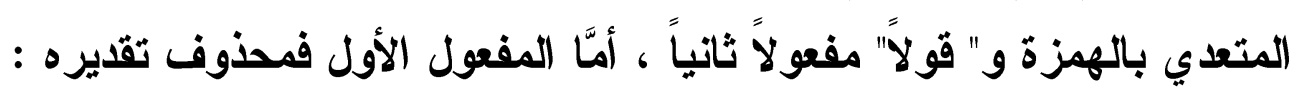

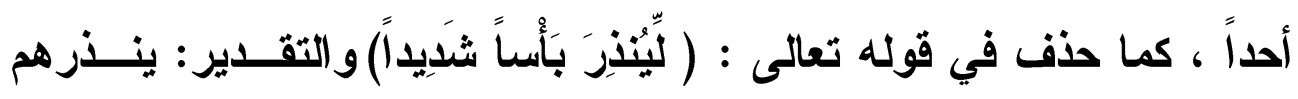
بأساً.

$$
\begin{aligned}
& \text { (1) سورة الكهف من الآية r }
\end{aligned}
$$

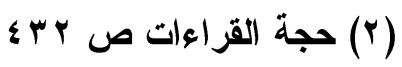

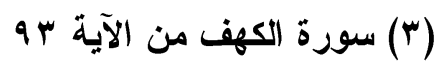

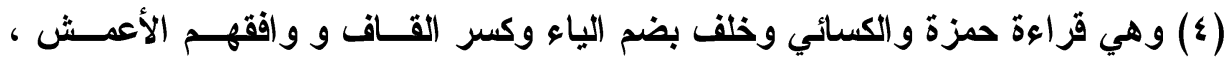

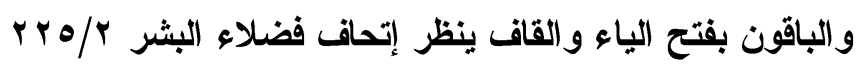




\section{الترقيم الدولي}

ISSN 2356-9050
P.
حولية كلية اللفة العربية بجرجا مجية مجلة علمية محكمة

يجدر بي قبل أن أخص الفعل ( فقه ) وتعديه أن أبيّن في إيجاز تعريف

المتعدي ، وحكمه ، وأنواعه :

ينقسم الفعل إلى : متعدٍّ ، ولازم .

والمتعدي : هو الناصب مفعولاً دون حاجة إلى تقدير حرف جر (1)

أو هو : ما يجاوز الفاعل إلى المفعول به بنفسه(؟) ومن أسمائه : مجــاوزاً

لمجاوزته الفاعل إلى المفعول به ويسمى : واقعاً لوقوعه على المفعول به(بها"

\section{علامتهه :}

- - صلاحيته لأن يتصل به هاء ضمير تعود على غير المصدر وأضاف ابن

مالأك كاف الضمير وتاعه(ء) r- أن يبنى منه اسم مفعول تام .

مثل : ضرب ، فيصح أن يقال : زيدّ ضربه عمرو، فتتصل بـهـ هــاء ضمير غير المصدر وهو زيد وتقول : هو مضروبٌ فيكون اسم مفعول تام .

أن ينصب مفعولاً به (0) .

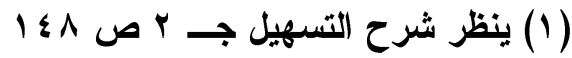

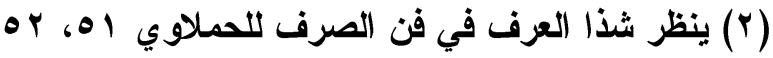

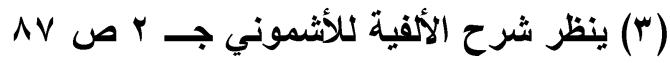

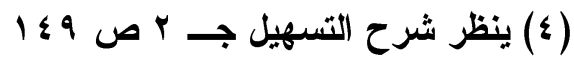

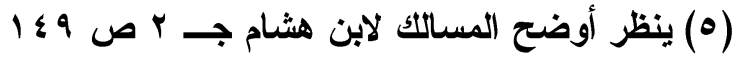



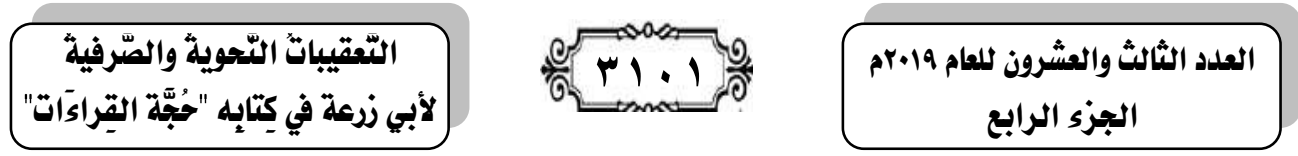

ومن أسباب تعدية الفعل : الهمزة ، والتثديد ، وحرف الجر. تتصـل

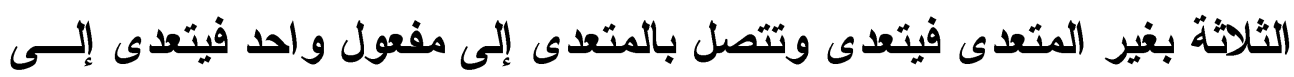

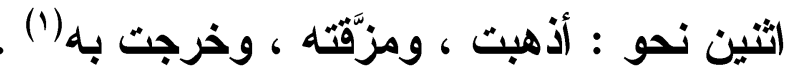
أنواع المتعدي : أنون

1- ما يتعدى إلى مفعول واحد وهو كثير نحو: حفظ محمدٌ الدرسن ، وفهـــ المسألةً

r- ما يتعدى إلى مفعولين إما أن يكون أصلهما المبتدأ والخبر وهو" ظن "

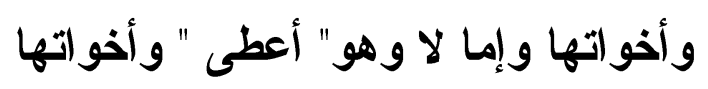

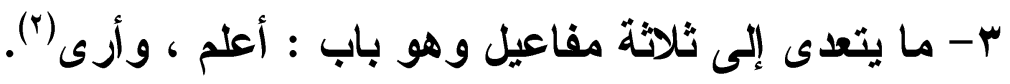

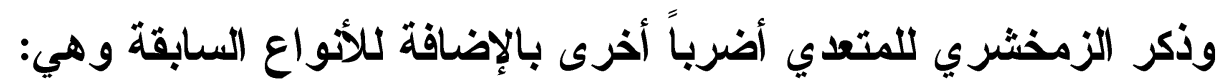
الأول : ضرَب منقول بالهمزة عن المتعدى إلى مفعولين وهو فعلان :

$$
\text { أعلمت وأريت }
$$

الثاني : ضرَبْ مُتَعَّة إلى مفعول واحد وأجرى مجرى أعلمت لموافقته

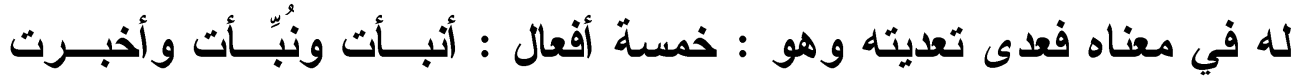

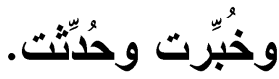

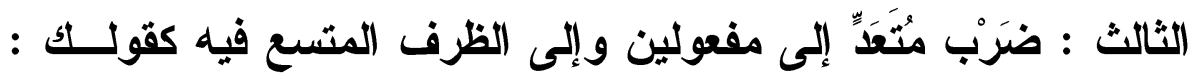

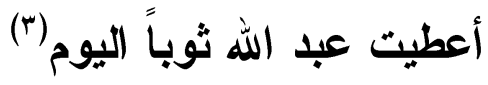

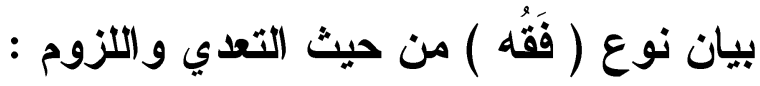

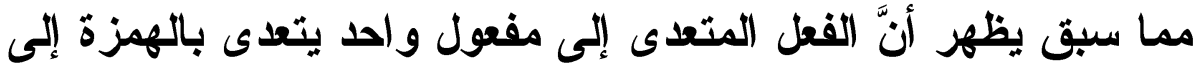

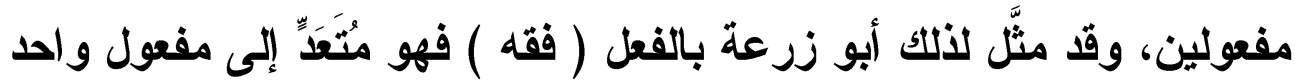

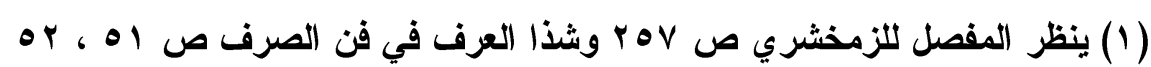

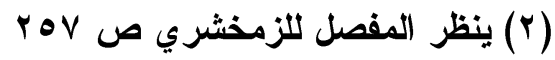

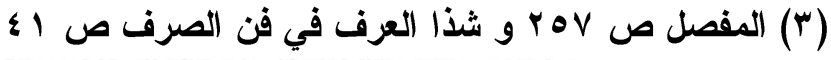




\section{الترقيم الدولخ}

ISSN 2356-9050
T.

حولية كلية اللفة العربية بجرجا مجلة علمية محكمة

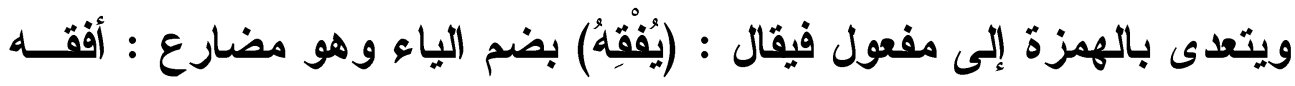

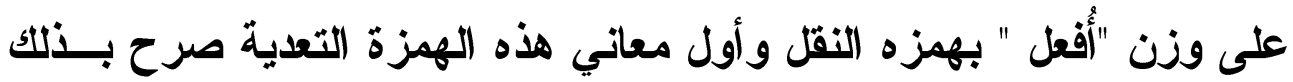

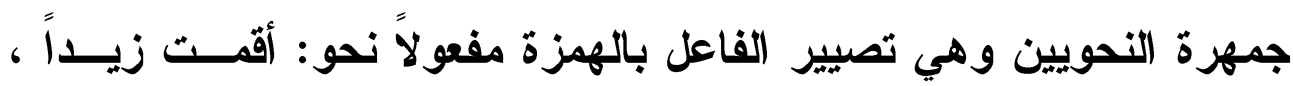

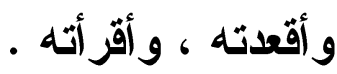

ويترتب على ذلك أنَّ الفعل إذا كان لازماً تعدى إلى مفعول واحد ، وإن

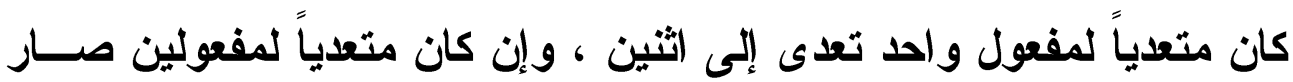
بالاهمزة متعدياً إلى ثلانة (1) وقد ذكر سييويه ذلك كله وأطال القول فيه تحت عنوان : (هــذا بــاب (فتراق فعلت وأفعلت في الفعل للمعنى) وفيه أقاد بتأثثر الهمزة الاخلة على الفعل اللازم فتصيره متعدياً إلـى مفعول واحد فقال: ( تقول : دخل ، وخرج ، وجلس) فإذا أخبرت أنَّ غيــره صيره إلى شيء من هذا قلت : أخرجه ، وأدخله ، وأجلسه) (r)

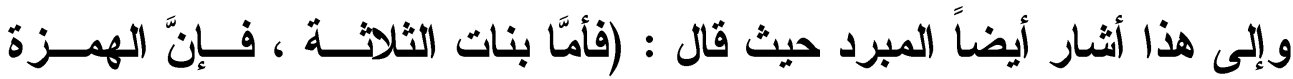
تلحقها أولاً فيكون الفعل على أفعل نحو: أخرج وأكرم ويكون المستقبل نحو:

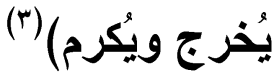
وبعد : فما ذكره أبو زرعة لم يخرج عما ذكره النحويون والصرفيون في هذه المسألة ، وهى مسألة اتفاقية لم أجد من خالف فيها ، وذلك فيمــا اطلعت عليه من كتب .

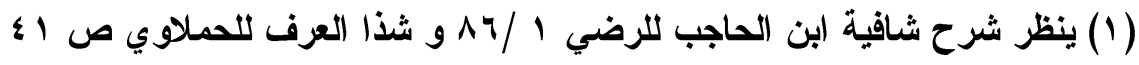

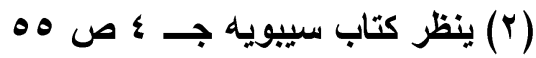

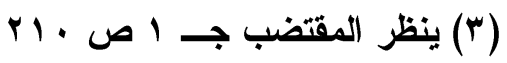


التصقيباتُ التّحويثة والصّرفية

لأبي زرعة في كِتابه "حُجَّة القِراءَاتَ"

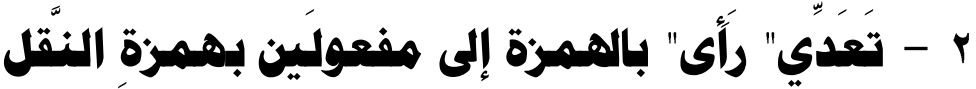

قال الإمام أبو زرعة :(أعلم أنَّ "رأى " فعل يتعدى إلى مفعـول واحـــ

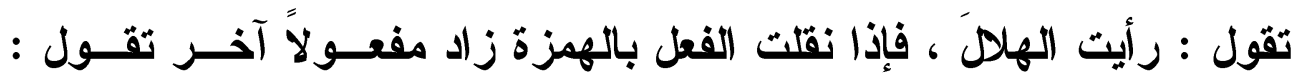

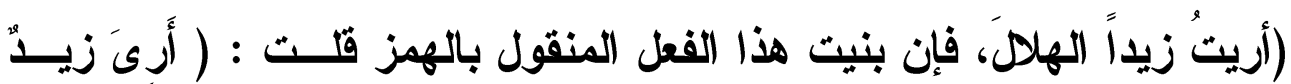
الههلا) فيقوم المفعول الأول مقام الفاعل ويبقى الفعل متعدياً إلــى مفعــول

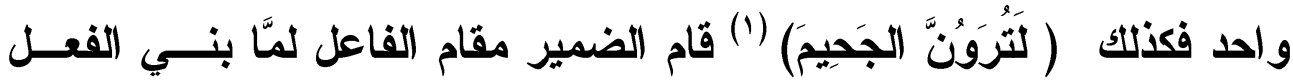

للمفعول به (أتت) وانتصب "(الجحيم" على أنَّه مفعول) (r). ما تضمنه كلام أبي زرعة من أفكار :

- - تناول أبو زرعة الفعل المتعدى إلى مفعول واحد ، والأى تنقله الهمــزة • إلى مفعولين

r - دلل أبو زرعة على ذلك بأنَّ الفعل إذا بني للمجهول ناب المفعول الأول عن القاعل ورفع وبقي الفعل متعدياً إلى الثاني فيعرب مفعولاً لهذا الفعل . ب- ذكر من ذللك قراعة :( لَتَرَوْنَّ الجَحِيمَ) بضم التاع(َ) على بناء الفعل ترى للمجهول ، وهنا عدى الفعل إلى مفعـولين بــالاهمزة ، الأول هــو : واو الجماعة وقد ناب عن القاعل ، أمَّا الثاني فهو : (الجحيم) .

(1) سورة التكاثر آية ج ، وقر اعة ( لَتَرَونَّ ) - بضم التاء - لابن عامر ، والكسائي ينظر

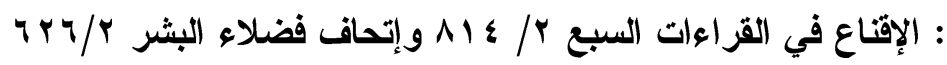

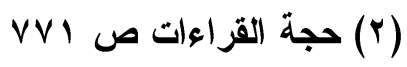

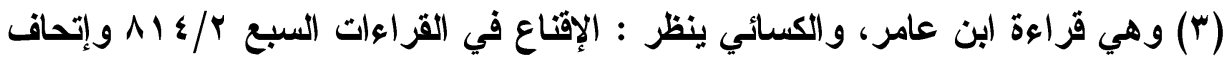

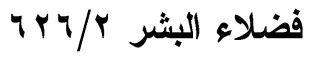




\section{الترقير الدولخ \\ ISSN 2356-9050}

ع - يقصد أبو زرعة هنا بالفعل (رأى) رأى البصرية أمَّا رأى التي بمعنـى علم ، فإنَّها تتعدى بالّهزة إلى ثلاثية مفاعيل. ه - قد لاحظت هنا أمرين من خلال كلام أبى زرعة . أولهما : قوله :(أعلم) بهمزة قطع ويبدو أنَّه خطأ مطبعـي ولا يقصـــ أن يكون أعلم فعل مضارع وفاعله ضمير المــتكلم المسـتـر وجوبــاً ولكـن المقصود هنا "اعلم" فعل أمر بدليل أنَّه يخاطب القارئ بقوله : ( تقول ) . الثاني : قوله : زاد مفعولاً بنصب كلمة "مفعولاً " فالأي يظهر أنَّه يقصد زاد المتكلم مفعولاً . الفعل (رأى ) بين المعنى ، والعمل :

سبق لي الحديث عن أنَّ الفعل المتعدى إلى مفعول واحد يتعدى بالههز

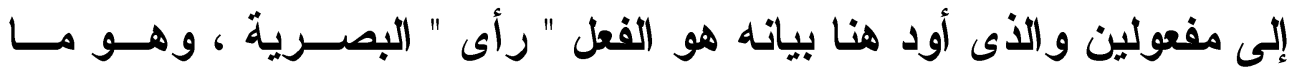

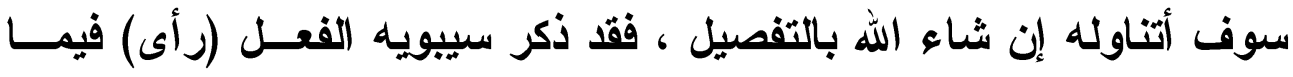
يتعدى إلى مفعولين بنفسه إذا كان بمعنى :علم قال في باب الفاعـلـل الــــى يتعداه فعله إلى مفعولين : ( ومثل ذلك : رأى عبد الله زيداً صاحبنا ، ووجد عبد الله زيداً ذا الحفاظ ، وإنَّما منعك أن تقتصر على أحد المفعــولين ههزـــا أنَّك إنَّما أردث أن تبين ما استقر عندك من حال المفعول الأول يقيناً كان أو

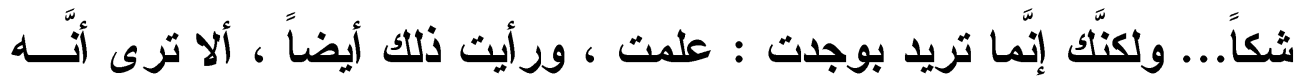

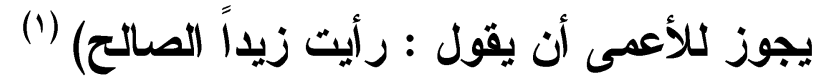




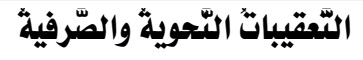

لأبي زرعة في كِتابه "حُجَّة القِراءَات"
Q. 1.00

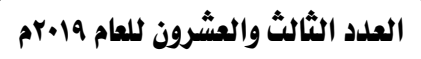

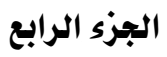

أمَّا إذا كان (رأى) يفيد روئية العين تعدى إلى مفعول واحد بنفسه قـال

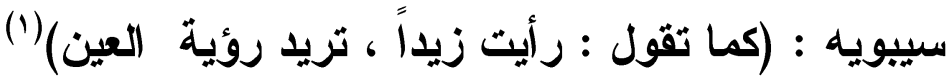

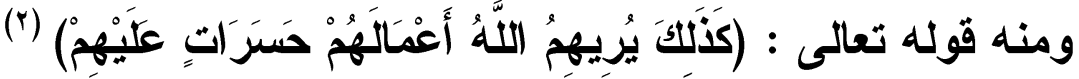
فإذا دخلت الهمزة على هذا الفعل تعدى إلى مفعولين .

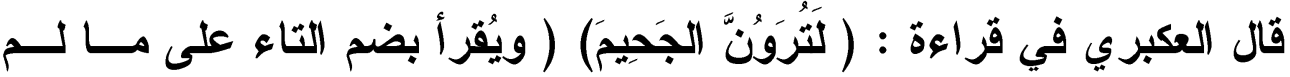

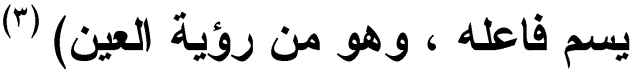

وفصَّل ابن مالك أيضاً القول في هذا المضمار فقال : (تدخل في هــا

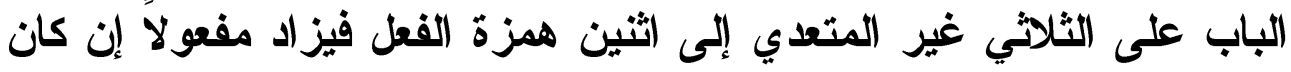

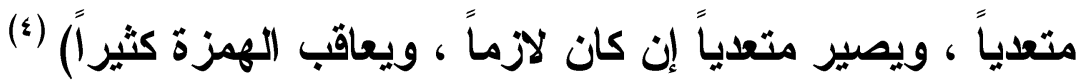

ولم أجد من يخالف في ذلك ، فالجميع متفقون على أنَّ ما يتعدى إلـى

مفعول واحد تنقله الهمزة إلى مفعول آخر فيصير لله مفعولان ، فــإذا بنــى

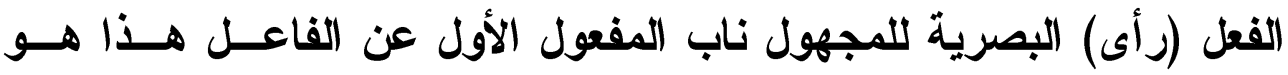

(الأثهرز (ن)

و المتفق عليه أنَّه إذا أمن اللبس جاز إنابة المفعول الثاني عن الفاعل

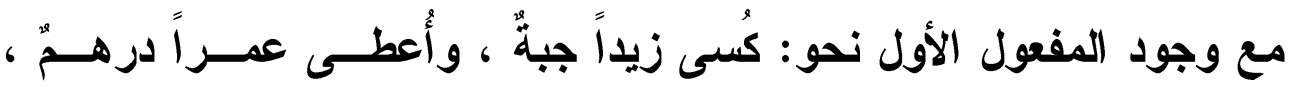

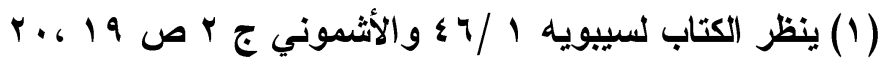

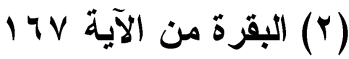

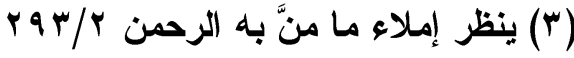

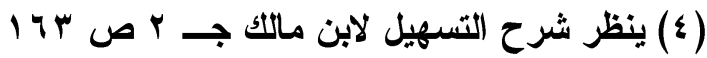

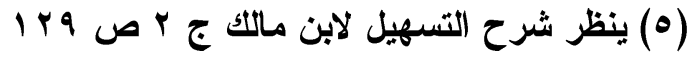




\section{الترقير الدولخ \\ ISSN 2356-9050}

بخلاف ما لم يؤمن فيه اللبس نحو: أُعطى زيداً عمرو، فيتعين هنــا إنابــة الأول ؛ لأنَّ كلاً منهما يصلح لأن يكون آخذاً (1)

و إذا كان الأول معرفة والثاني نكرة فقد قال البصريون بجــواز إنابــة الثاني وإن كان الأول نكرة ، فإقامة الثاني قبيحة وإن كانا معرفتين اسـتويا في الحسن (r) وبعد : فالذي ذكره النحويون في هذا المضمار لخصه ابن هشام فـي النقاط الآتية :

- 1 حكاية الإجماع على جواز إقامة الثاني من باب "كسا" حيث لا لبس .

r) - عدم اشتر اط كون الثاني من باب "ظن "إن لم يلبس ولم يكن جملة . أمَّا عن الإمام أبى زرعة فقد تناول القضية من جهتين : الأولى : تعدي الفعل " رأى " البصرية عـن طريــق همـزة النقـلـ (التعدية) إلى مفعول واحد وبالاهمزة إلى مفعولين • الثانية : إنابة المفعول الأول عن الفاعل ، وفى هاتين الجهتين لم أجده قد خالف شيئًا مما قرره النحويون وإن لم يكن في كلامه ذكر نوع رأى . كما أنَّهُه لم يظهر رأيه في حكم إنابة المفعول الثاني عن الفاعـلـل مــع وجود المفعول الأول لكن في توجيهه لقراعة (لتُرون) بأنَّ الجحيم مفعول به دل على أنَّهُ يرى أنَّ المفعول الأول هو الأى ناب عن الفاعل .

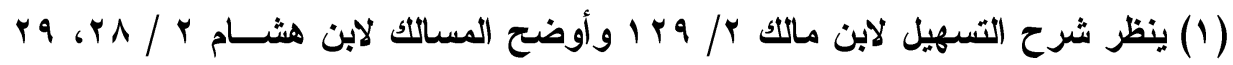

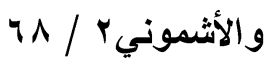

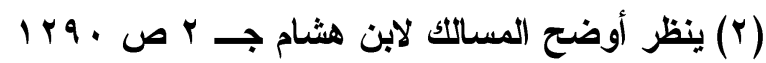

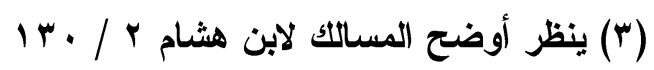

\section{0}


التّقيباتُ التّحويةٌ والصّرفية

لأبي زرعة في كِتابه "حُجَّة القِراءَاتَ"
PI.

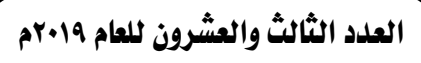

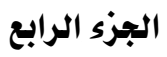

\section{باب الاستثناs}

\section{إعراب المستثنى في الككلام التام المنفي}

قال الإمام أبو زرعة : (واعلم أنَّ الاختيار في الاستثناء إذا كان منفياً وكان ما بعد إلَّا من جنس ما قبلها فالرفع أولى على البدل كقولك : ( ما في

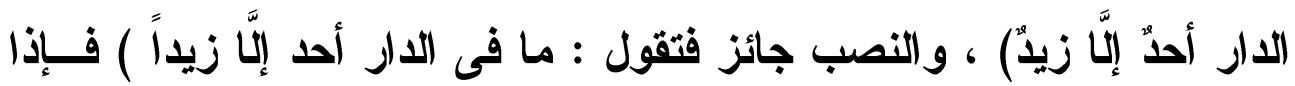

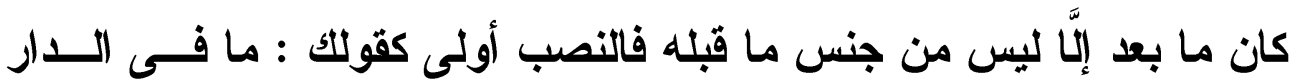

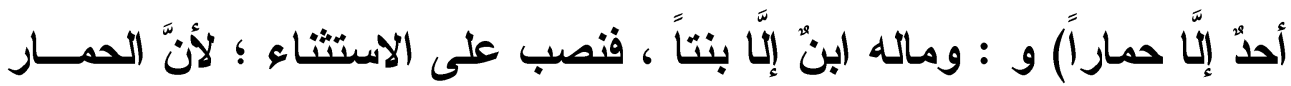
لا يكون من جنس الإنسان والرفع جائز على البدل قال الثاعر : (1)

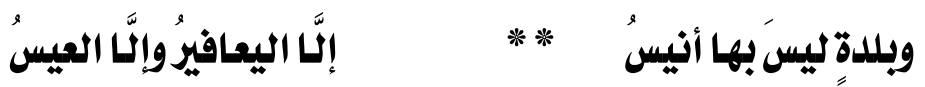

وجائز أن يكون جعل أنيس ذلك البلد اليعافير والعيس.(r) الأفكار الواردة في كلام أبى زرعة : 1 - تناول أبو زرعة الأوجه الواردة في المستثى بعد كلام تام منفى سواء أكان الاستثناء متصلاً أم منقطعاً.

(1) البيت من الرجز ، قائله : عامر بن الحارث المعروف بجران العود ، ينظر : ديواتــهـ

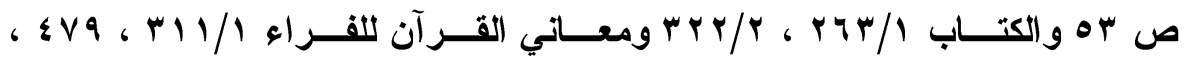

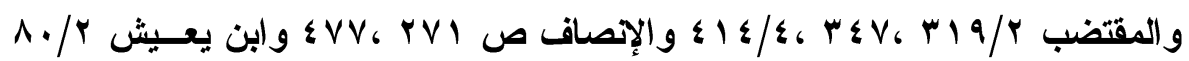

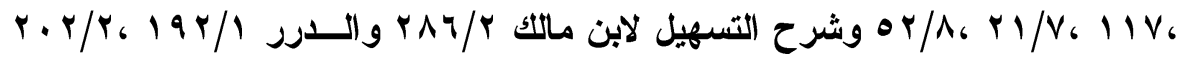

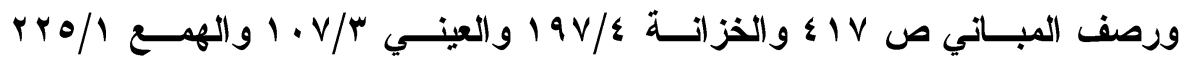

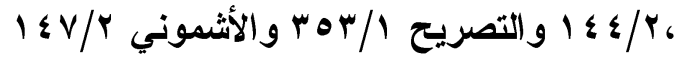

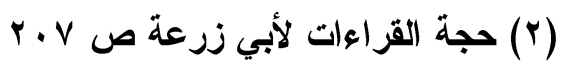




\section{الترقير الدولخ \\ ISSN 2356-9050}

r - تناول أبو زرعة المستثنى من كلام تام منفي متصل ، وهو الأى يكون

فيه المستثىى من جنس المستثنى منه نحو: ما في الدار أحدّ إلَّا زيدٌٌ .

وأجاز فيه وحهن:

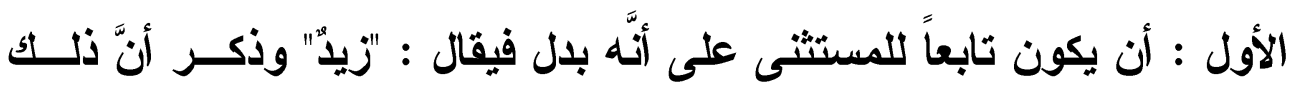
راجح وعبر عن ذلك بقوله : الاختيار على أنَّ الأكثرية من النحــويين

يختارون البدلية .

الثاني : النصب على الاستثناء فيقال : "زيداً "وهذا مرجوح .

r - أنَّ المستثنى من كلام تام منفى منقطع بأن كان المستثنى خارجاً عـن

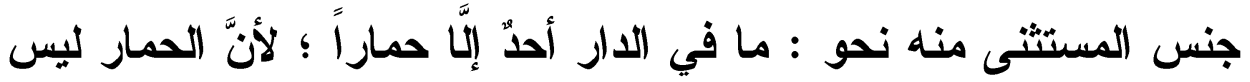
من جنس "أحد" فيجوز في المستثى وجهان :

الأول : أنَّه منصوب على الاستثناء فيقال : "حماراً" ، وهذا هو الراجح . الثاني : أنَّهـه تابع لأحد على أنَّهَ بدل ، وهذا مرجوح.

ع - مثَّل أبو زرعة لهذا النوع الأخير بقول الثاعر السابق والشاهد فيــهـ :

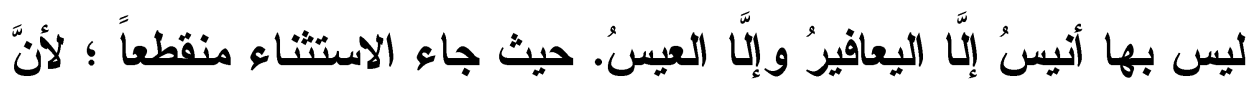
اليعافير، و العيس ليس من جنس أنيس .

ولكنَّه أجاز أيضاً كونه استثناء متصلاً ، والمعنى : أنَّ أنبس هذا البلا هو : اليعافير والعيس ، واليعافير في هذا البيث بلدل من "أنيس " بناءً علــى هذا المعنى. ه - استعمل أبو زرعة قوله : منفياً ، ولعله يقصد غير موجب ؛ لأََّّه أعــم وأثمل من النفي - ائ 


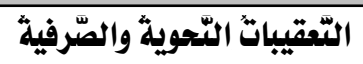

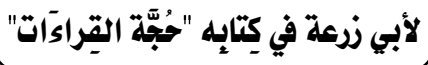

\%

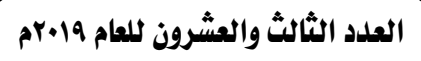
الجزء الرابع

حم الاستثناء من الكلام التام المنفي وحكم المستثنى بعده :

أعرض هنا ما قرره النحويون على سبيل الإجمال في هذا النوع مـن الاستثناء ، وهو الاستثناء من كلام تام غير موجب سواء أكــان متصــلاً أم منقطاً

وغير الموجب يشمل المنفى والأى سبقه نهي ، أو استفهام إنكاري (1) فإن كان الكلام غير موجب وكان متصلاً ففي المستثنى وجهان : الأول : وهو الأرجح الآباع في المستثنى للمسنثنى منه ،وفـى نـوع

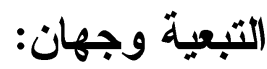

1 - البدلية ، وبه قال البصريون على أنَّ المستثنى بلدل بعض من كل مــن المستثى منه ، فيرفع إن كان المستثى منه مرفوعاً ، وينصب إن كــان المسنثى منه منصوباً ، ويجر إن كان المستثلى منه مجروراً.

r) - عطف النسق ، ويه قال الكوفيون فإلَّا هنا عندهم حرف عطف . (r)

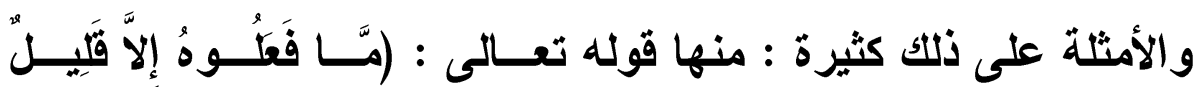

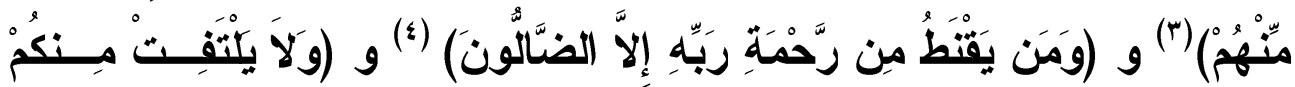

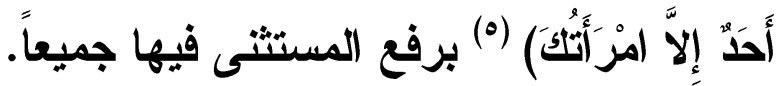

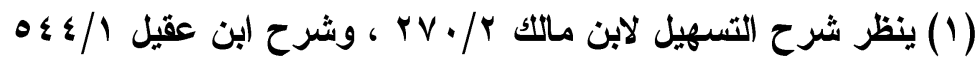

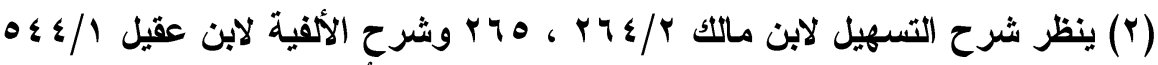

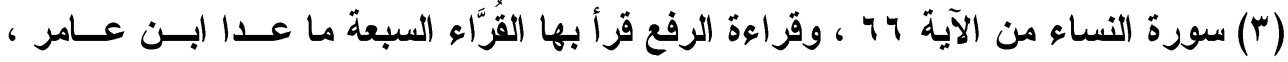

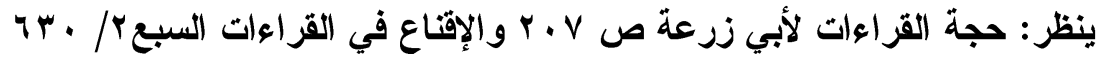

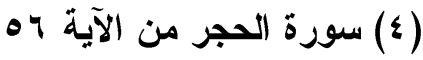

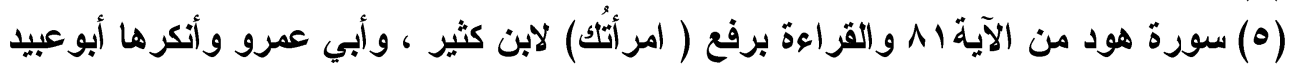

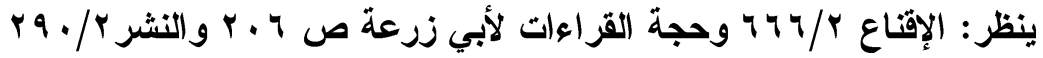




\section{الترقير الدولخ \\ ISSN 2356-9050}

الثاني : النصب وهو عربي جيد ، (')وبه قريء في " قليل" (ז)، و"امر أتك"(ب) ويجدر بي هنا أن أعرض بشيء من التفصيل لآراء النحويين لأبسين

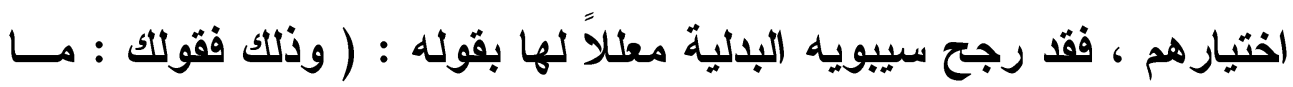

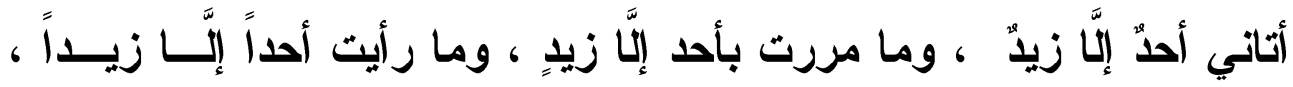
جعت المستثنى بدلاً من الأول ، فكأنَّك قلت : ما مررت إلَّا بزيدٍ ، وما أتاني

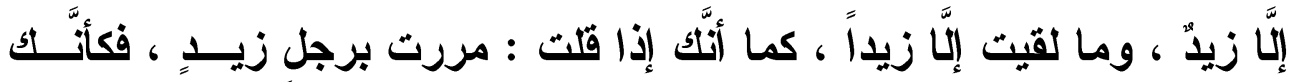
قلت : مررث بزيلٍٍ ، فهذا وجه الكلام أن تجعل المستثنى بدلاً من الأى قبالــهـ لألَّك تلاخله فيما أخرجت منه الأول) (๕). فقد اختار البلالية في المستثنى من كلام تام منفي ، وهو ما عليه أكثر النحويين كما سيأني ودلل المبرد على البدلية بقوله : (لأكَّك لمَّا قلت : جاعني القوم ، وقع

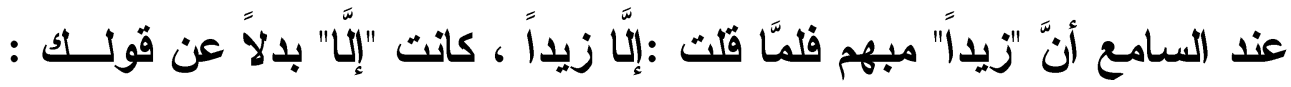

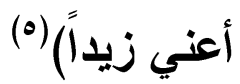

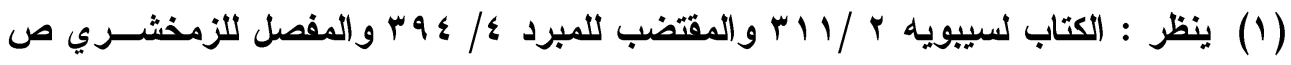

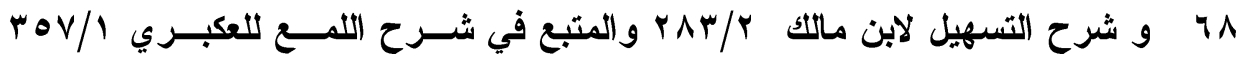

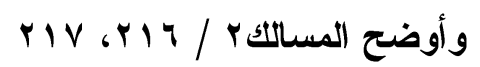

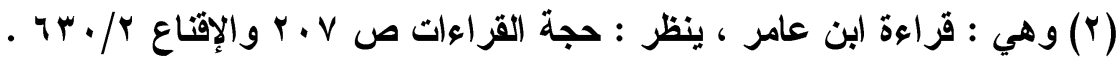

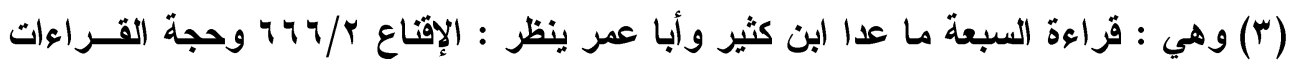

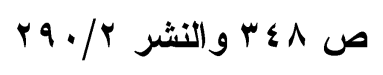

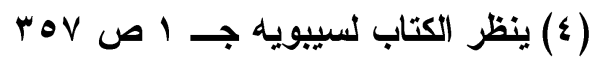

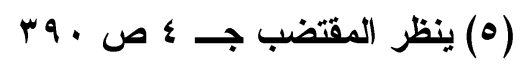




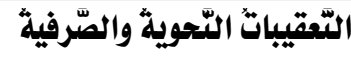
لأبي زرعة في كِتابه "حُجَّة القِراءَات"
W 111

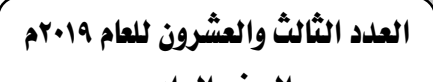

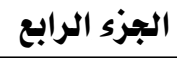

واختار الزمخثري أيضاً البلال وأجاز معه النصب على الاستثناء قال :

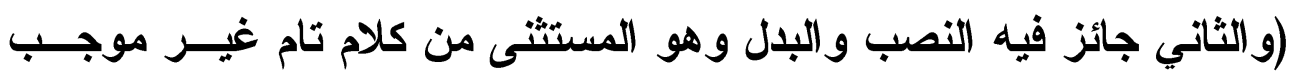

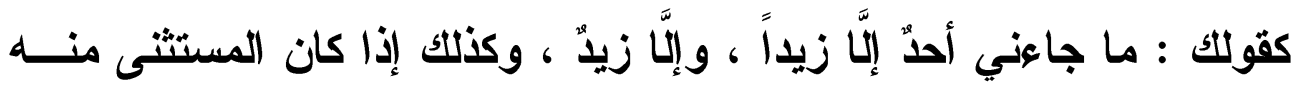

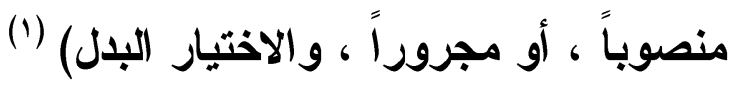

أمَّا العكبري فقد جعل النصب بعد الكلام غير الموجب كالنصـب بعـــ

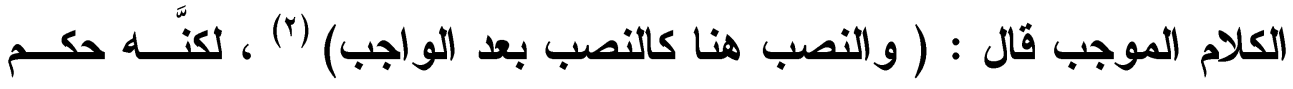

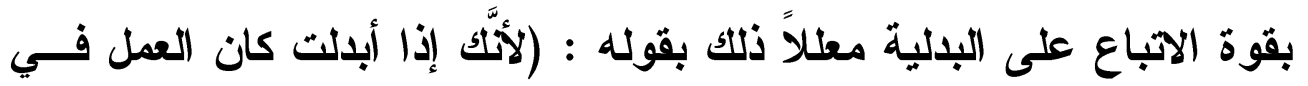

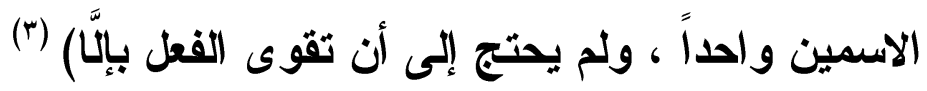

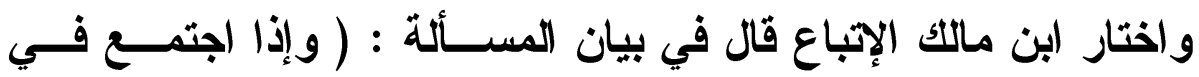

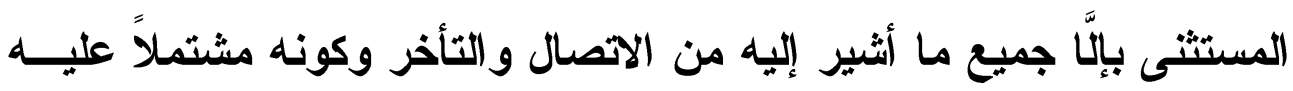

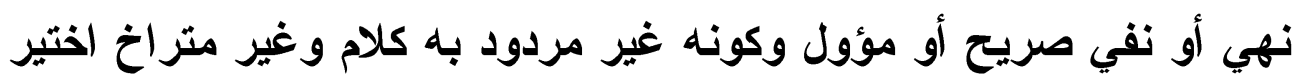

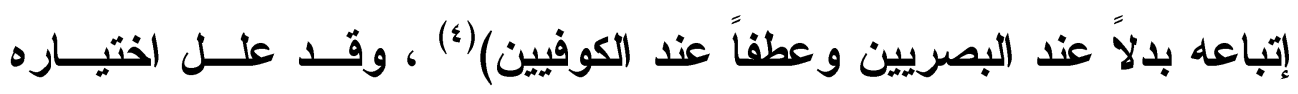

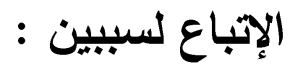
الأول : أنَّ المعنى في غير الموجب كالمعنى في الموجب. والثاني : تثاكل اللفظين في الإباع •

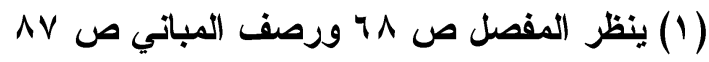

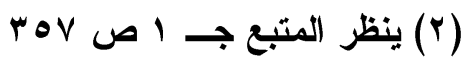
roV

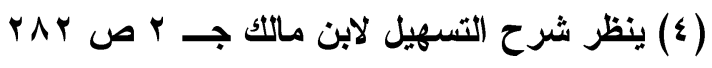




\section{الترقيم الدوله \\ ISSN 2356-9050}

قال :(لأنَّ سبب ترجيح الإتباع طلب التشــاكل ، وقـــ ضـــف داعيـهـ

(1) بالتباعد)

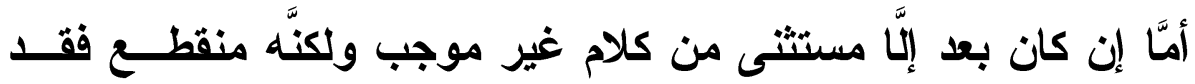

اختار النحويون في هذه الحالة نصب المستثنى(؟)

بل إنَّ النحويين اتفقوا على نصب المستثنى إذا لم يمكن تسليط العامل عليه نحو: ما زاد هذا المال إلَّا ما نقص فلا يجوز ما زاد النقص .

أمَّا إن أمكن تسليط العامل ، فالحجازيون يوجبون النصب ، وعليــهـ قــراعة

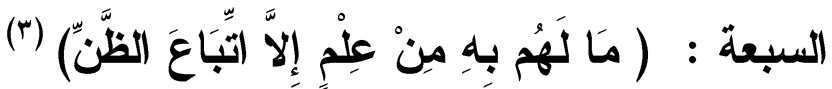

وتميم ترجح النصب وتجيز الاتباع على البدلية بدليل قول الثاعر:

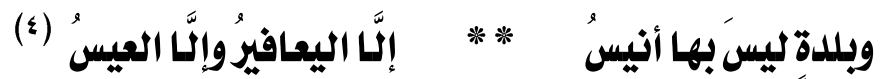

وتكون إلَّا في الاسنثناء المنقطع بمعنى لكن .

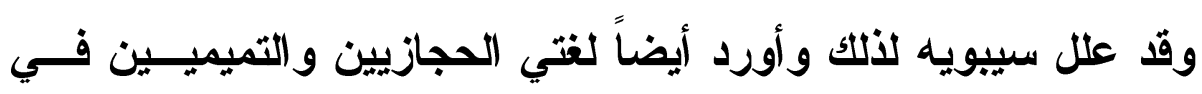

(هذا باب يختار فيه النصب ؛ لأنَّ الآخر ليس من نوع الأول).

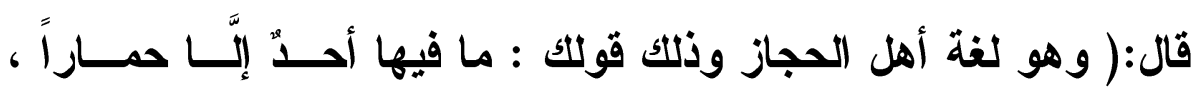

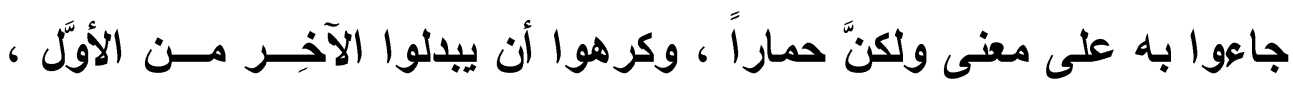

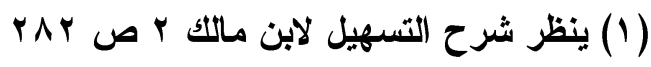

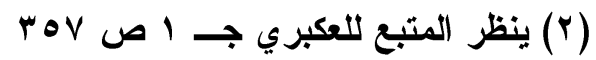

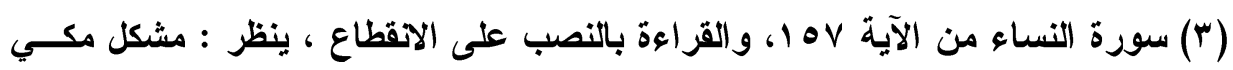

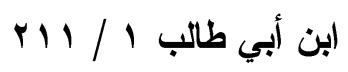

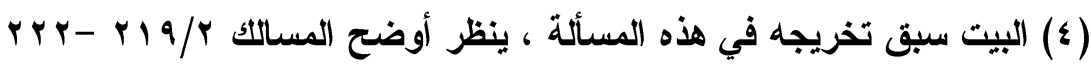




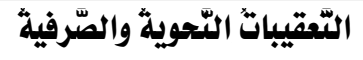

لأبي زرعة في كِتابه "حُجَّة القِراءَات"
Piा

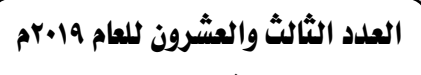

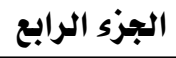

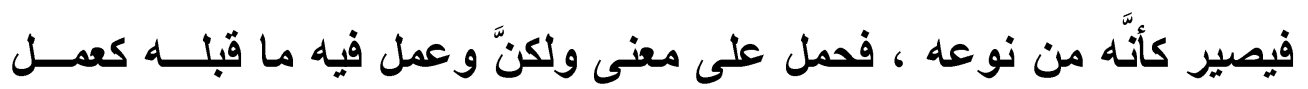

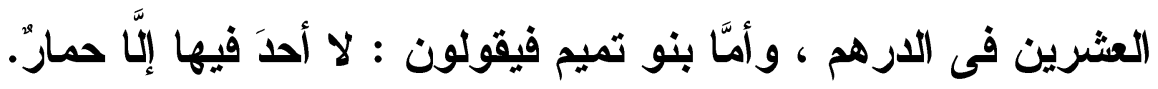

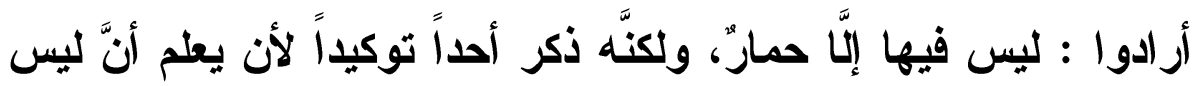

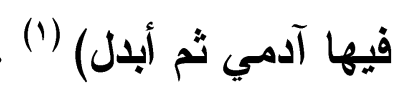

وعلل العكبري لتفضيل النصب على البدل بقوله :(وإن كان النصب هنا

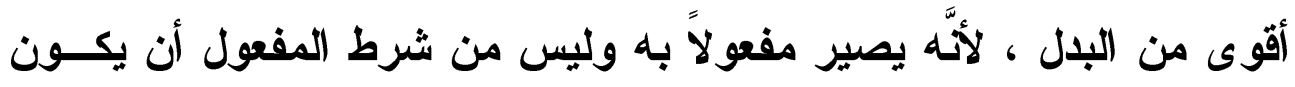

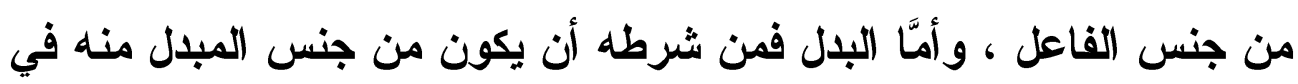

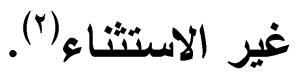
وأخيراً : فإنَّ أبا زرعة لم يخرج في عرضه لهذه القضــية النحويـــة

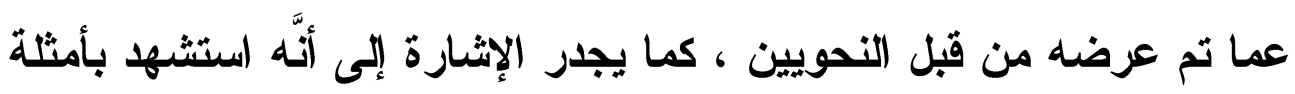
توضيحية ملائمة . وإن كان قد عبَّر عن هذا النوع من الاستثناء بالاستثناء من كلام تسام

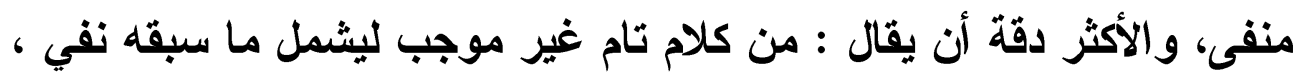

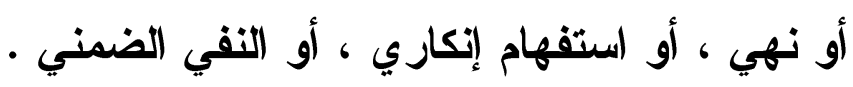

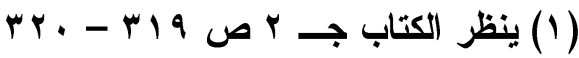

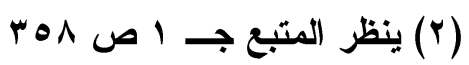




\section{الترقيم الدولم \\ ISSN 2356-9050}

\section{باب المصف}

\section{1- عطف الظاهر على الضمير الجزرور بدون إعادة الجار .}

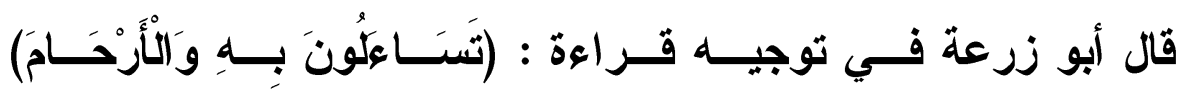
بالخفض(1):"قال أهل النحو يبطل الخفض من وجهين :

أحدها : ما روي عن النبي- صلى الله عليه وسلم - قال: "لا تحلفوا

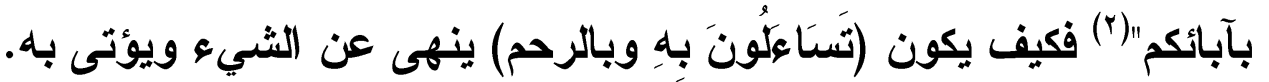
و الوجه الثاني : ما ذكره الزجاج(") قال "أمَّا العربية فإجماع النحـــويين أنَّه يقبح أن ينست باسم ظاهر على اسم مضمر في حال الخفض إلَّا بإظهار

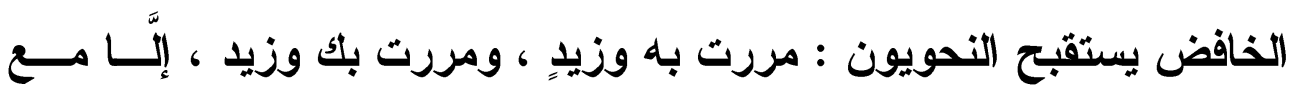
إظهار الخافض حتى يقولوا : بك وبزيد .

وقد فسر المازني هذا تفسيرًا مقنعًا ، فقال : الثاني في العطف شـــــــ

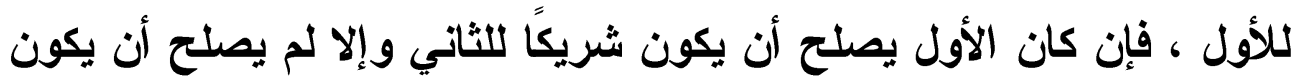

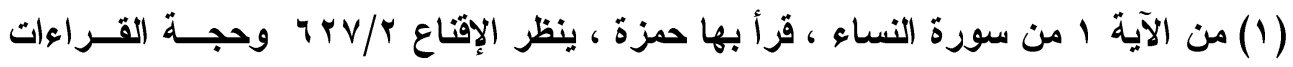

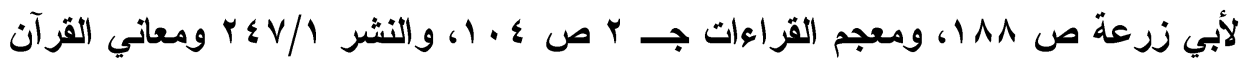

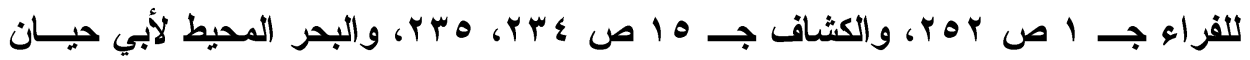

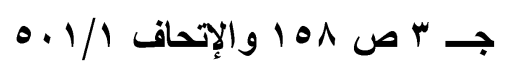

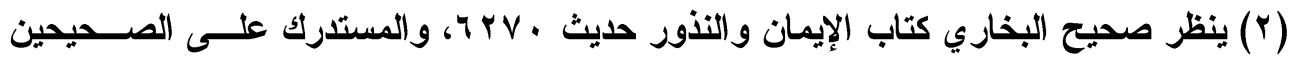

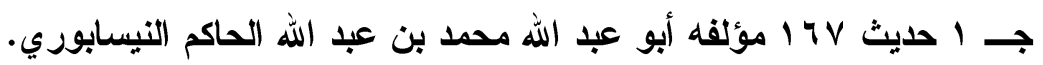

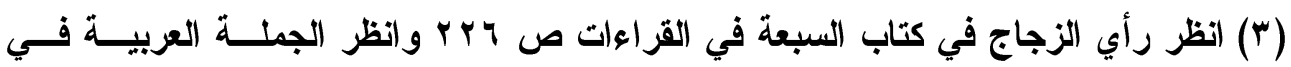

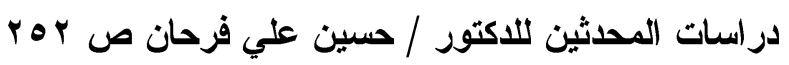




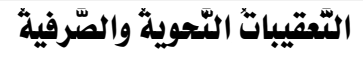

لأبي زرعة في كِتابِه "حُجَّة القِراكَاتَ"
PI 100

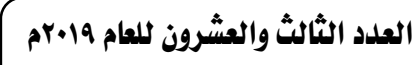

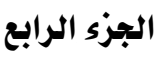

الثاني شريكًا له ، قال : فكما لا نقول : مررت بزيـ وك ، فكنلك لا نقــول :

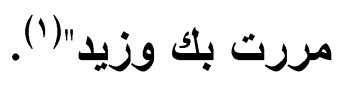

موقف أبي زدرعة من العطف على الضمبر المجرور دون إعادة الجهار. 1 - عرض أبو زرعة في توجيه قر اءة (الأرحام) بالخفض وجهـين ، وقــــ

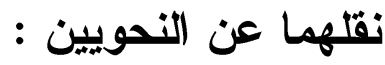

الوجه الأول : وله علاقة بالناحية الفقهية وتمثل ذلك في وجود تناقض بين

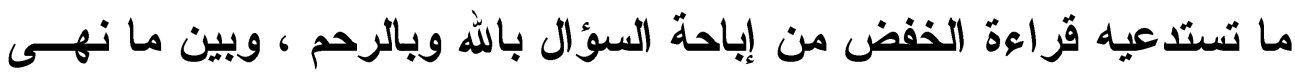

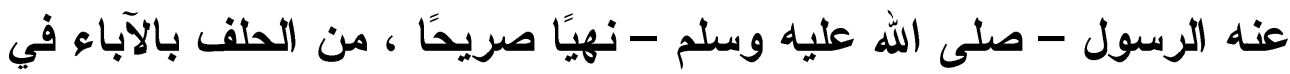
قوله - صلى الله عليه وسلم - (لا تحلفو ا بآبائكم) وعلى الــرغم مــن أنسَّهـه

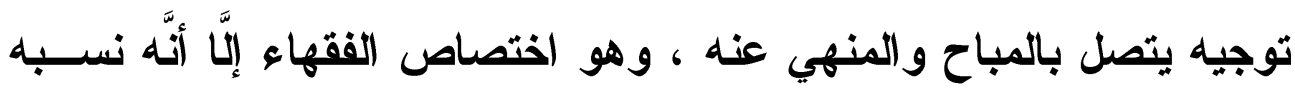
للنحويين.

الوجه الثاني : القاعدة النحوية تقول : إنَّه لا يجوز أن يعطف الاسم الظاهر

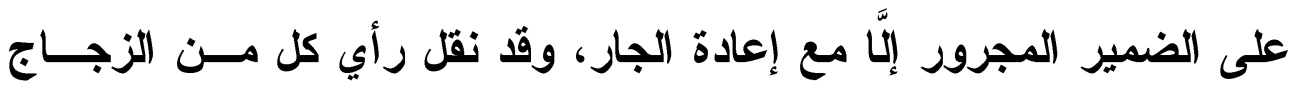

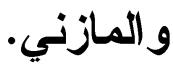

وقد مال إلى ما ذكره المازني واقتنع به لما فيه من ملاحة وفطنة. r- يظهر من خلال كلامه ميله إلى منع العطف في هذه الحالة إلَّا مع إعادة

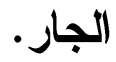

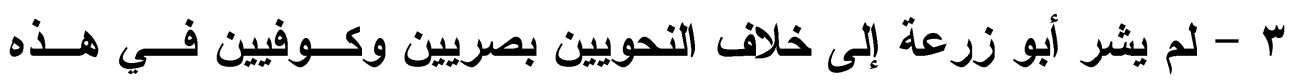

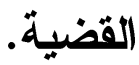

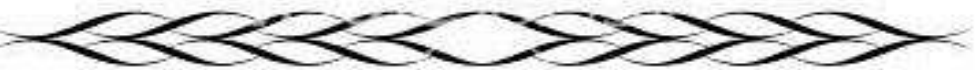




\section{الترقير الدوله}

ISSN 2356-9050
P117
حولية كلية اللفة العربية بجرجا مجية مجلة علمية محكمة

رأي النحويين في العطف على الضمير المجرور بدون إعادة الجار. هذه القضية كثر ورودها في كتب النحو ولا أبالغ إن قلت إنَّه لا يوجد كتاب في النحو خلى منها حتى كتب التفسير فإنَّها تناولت القراعات وأقاضت فـي التهي شروحها وتوجيهها.

ولذا ما أراه نافعًا هنا أن أتوجه في دراسة القضية وفق ما يقتضيه كلام أبي زرعة على أن أبدأ بما لم يتناوله من الخلاف بين المذهبين. رأي البصريين والكوفيين في هذه القضية : المشهور في هذه القضية مذهبان :

الأول : مذهب جمهور البصريين وهو : ألَّاَّا يجوز العطــف علـــى الضــميز

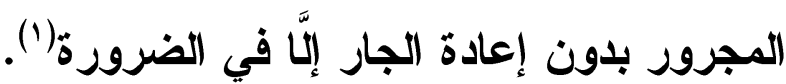
الثاني : مذهب الكوفين ، وتبعهم يونس والأخفش من البصريين أنَّه يجوز ذللك في سعة الكلام ، وليس خاصًا بالضرورة)(؟). وأضاف الرضي مذهبًا ثالثًا وهو : أنَّهَه إن أكد الضمير جاز، نحو: مررث بك أنت وزيدٍ ، وهو مذهب الجرمي والزيادي)(؟).

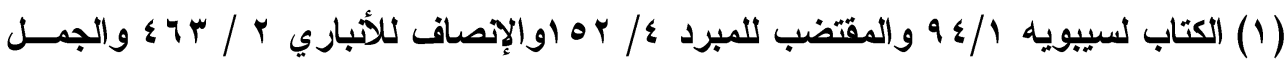

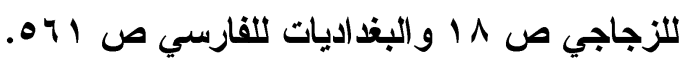

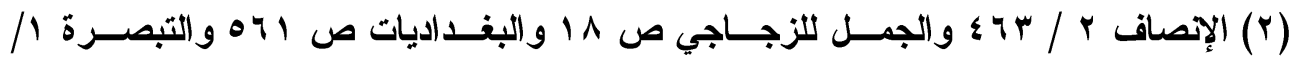

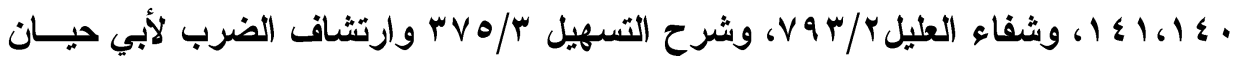

$$
r+1 \varepsilon, r \cdot 1 r / \varepsilon
$$

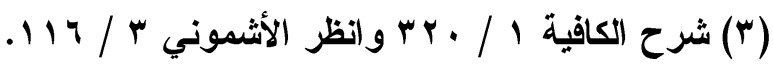


التّقيباتُ التّحوية والصّرفية لأبي زرعة في كِتابه "حُجَّة القِراءَاتَ" ril

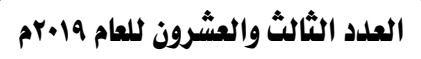

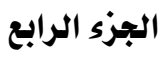

واحتج البصريون بحجتين :

إحساهـها : أنَّ ضمير الجر شبيه بالتنوين ، ومعاقب له ، فلا يعطف عليه ، كما لا يعطف على التنوين.

الثانية : أنَّ حق المططوف و المعطوف عليه أن يصلحا لحلول كـلـل منهمــــا

محل الآخر، وضمير الجر غير صالح لحلوله محل الاسم الظاهر ('). واحتج الكوفيون بوروده في السماع وأنَّه جائز في القياس.

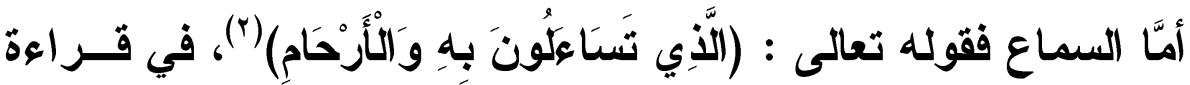

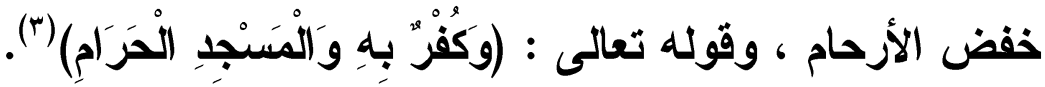

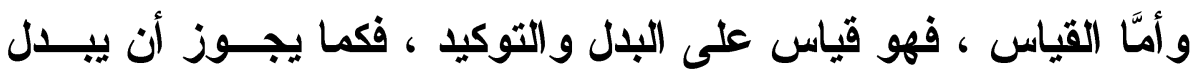
من الضمير المجرور، ويؤكد بدون إعادة الجار يجوز كذلك في العطف. وجعلوا منه قول الثاعر (๕):

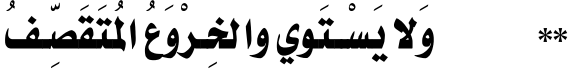

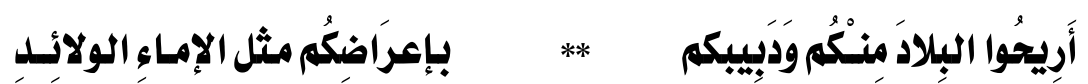

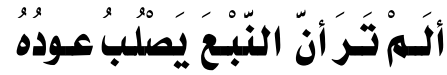

وقول الثاعر : (•)

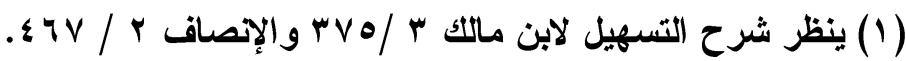

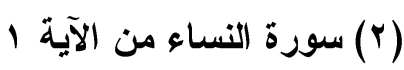

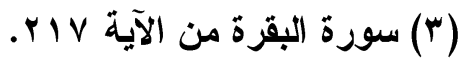

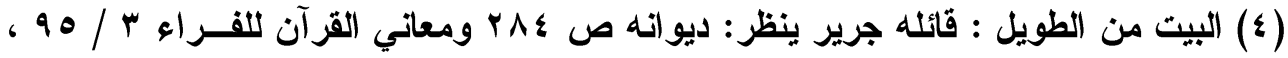

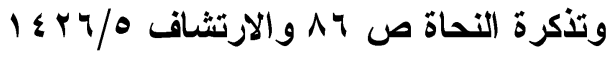

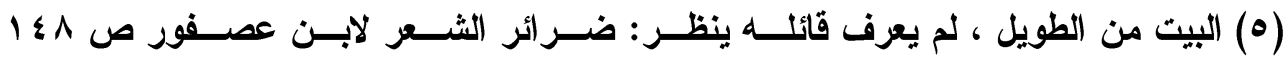

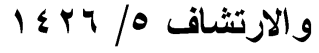

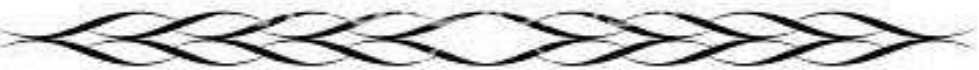




\section{الترقيم الدولم}

ISSN 2356-9050

وأمثال ذلك كثيرة ، فكما لم يمتنع فيها العطف لا يمتنع في ، نحو: مسررث

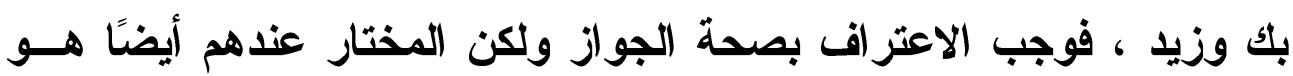

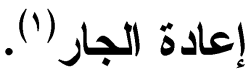

هذا هو الموضع الأول الأي عرضت فيه القضية من خلال الخــلاف الــوارد بين البصريين و الكوفيين.

أمَّا الموضع الثاني فهو مناقثة ما ذهب إليه المازني ، ونقله عنه أبو

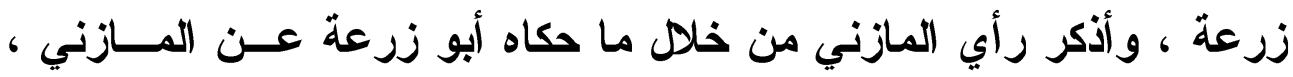

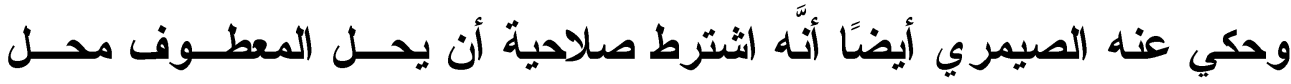
المعطوف عليه ، ويحل المعطوف عليه محل المعطوف ليصح العطف ، فإنَّما

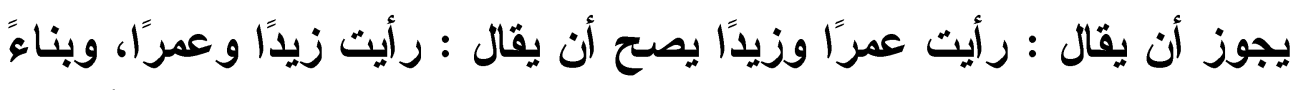
عليه ، لا يجوز العطف على الضمير المجرور بدون إعادة الجــار؛ لأَّــهـه لا

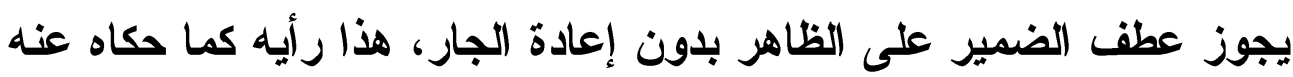
كثير من النحويين(؟).

ولكن ما أثاره من اثثتر اط صلاحية المعطوف عليه ليحل كـل منهمـــا محل الآخر لم يكن مجمعًا عليه بين النحويين.

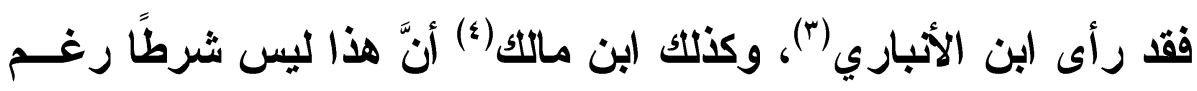
اختيارهما لإعادة الجار المعطوف.

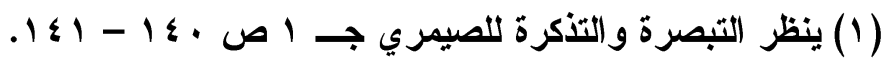

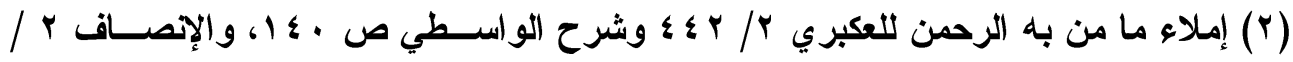

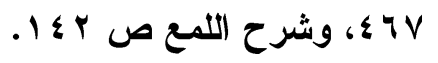

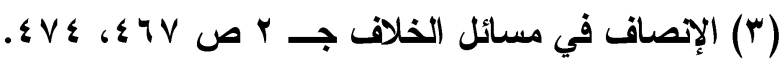

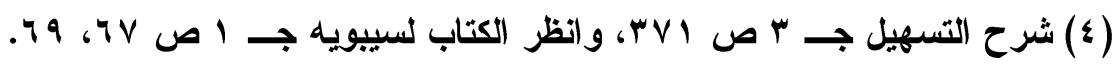




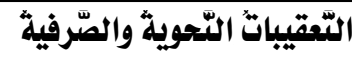

لأبي زرعة في كِتابهه "حُجَّة القِراكَاتِ"
P119

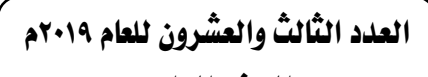

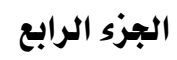

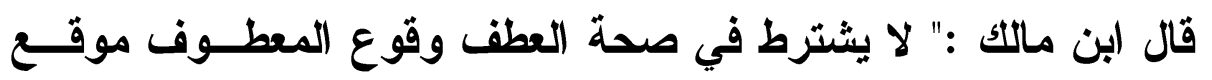
المعطوف عليه، ولا تقدير العامل بعـــ العــاطف ، بـل بثــترط صــلاحية المعظوف ، أو ما هو بمعناه لمباثرة العامل" (1).

وقد سبق في بيان حجة البصريين عرض هذا الثرط الذي نادى بـهـ

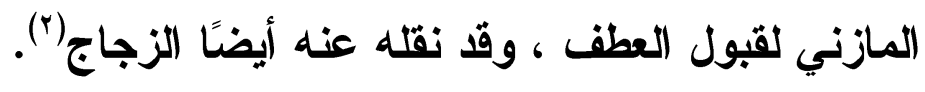

ويبدو أنَّ وصف أبي زرعة لكلامه بأنَّه مقتع أنَّه يميل إلــى المـــهب

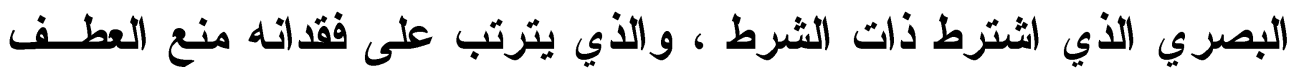

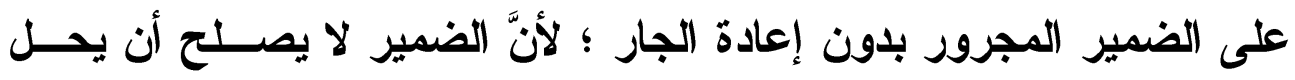

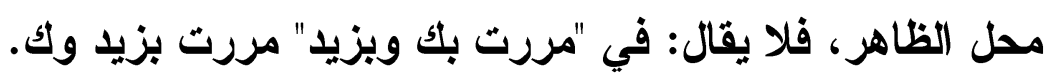

يبقى شيء لا بـ أن ألفت النظر إليه ، وهو أنَّ هذه القضية كانت مسن

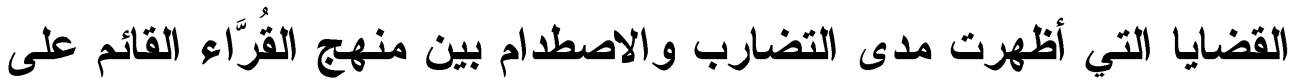

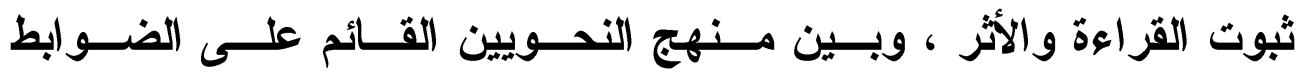

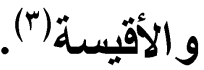

(1) شرح التسهيل جـ rVT (1)

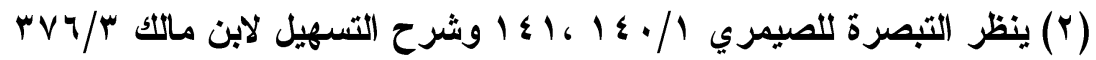

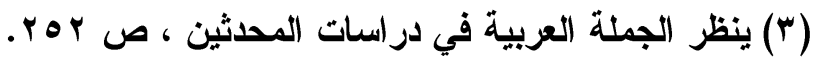




\section{الترقيم الدوله \\ ISSN 2356-9050}

\section{r - عطف الاسم الظاهر على الظاهر المجرور .}

قال أبو زرعة :"واختلف أهل النحو في ذلك فقال قوم : مسـررت بزيــــ

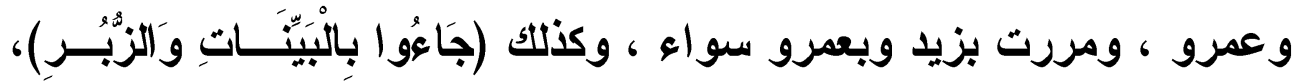

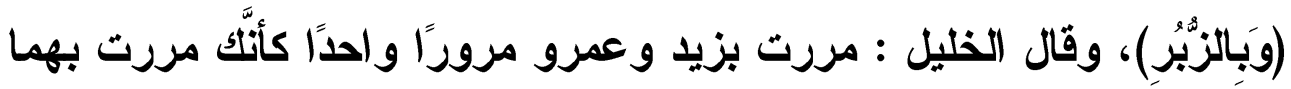

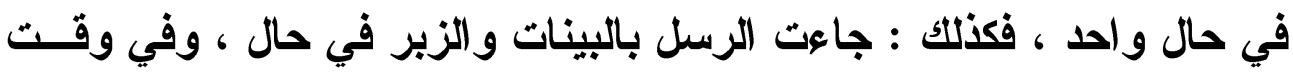
واحد ، ومررت بزيد وبعمرو مرورين ، هذا لا يكون في وقت واحد ، فكذلك

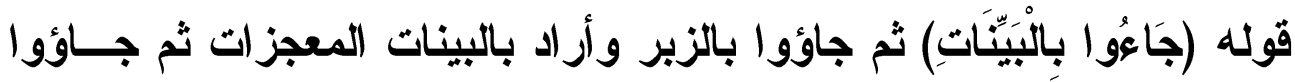
بعد ذلك بالزبر أي : بالكتب)(1). القضية التي أثارها أبو زرعة في تعقيبه : 1 - عرض أبو زرعة قضية مهمة جديرة بالبحث ، وهي الأثــر المعنــوي لاختلاف التركيبين (التعبيرين): الأول : وفيه عطف الظاهر على الظاهر المجرور بدون إعــادة العـاطف ، فيقال : (مررث بزيد وعمرو). التركيب الثاني : وفيه عطف الظاهر على الظاهر المجرور مع إعادة الجــار نحو : (مررت بزيد وبعمرو).

r- نسب للنحويين خلافًا في تفسير المعنى في التعبيرين السابقين ، وهـــا غير ظاهر في كتب النحو في حدود ما تيسر لي الاطلاع عليه. r- أورد أبو زرعة في تفسير المعنى في القضية السابقة مذهبين : 


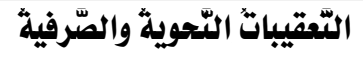

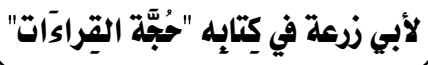

المذهب الأول : لم ينسبه لأصحابه ، وساوى هذا المذهب في المعنـى بـين التركيب مع إعادة الجار، والتركيب بدون إعادة الجار. المذهب الثاني : ونسبه للخليل ، ورأى أنَّ هناتك اختلافًا بين التعبيرين. وقد فسر الخليل هذا الاختلاف ، فهو يرى أنَّ قول القائل: (مررت بزيد

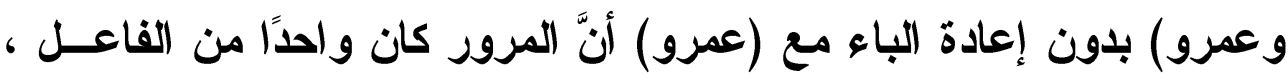
وكان حال زيد وعمرو واحدًا ، وكان من المرور واحدًا ، وعليه وجه قر اعة لهرة

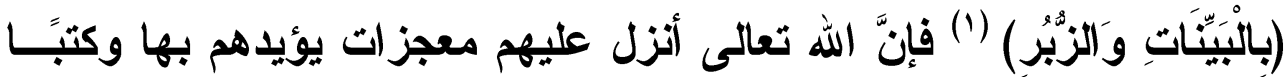
في فترة زمنية واحدة.

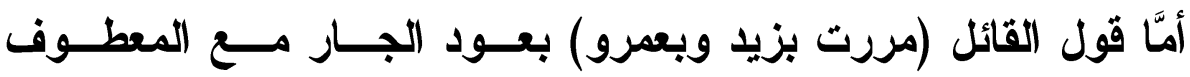
(عمرو)، فإنَّ مرور الفاعل كان مرورين ، فالحدث حدثان وزمسـن المــرور زمنان ، وحالهما مختلفة ، وليست واحدة.

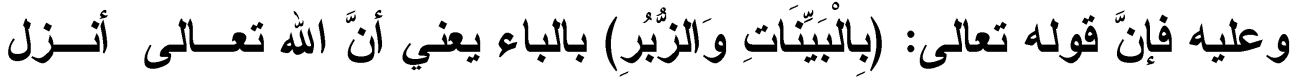
الكتب في زمان مغاير لزمن تأييده لهم بالمعجزات.

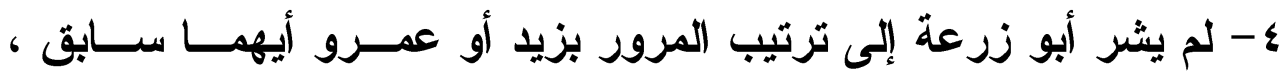

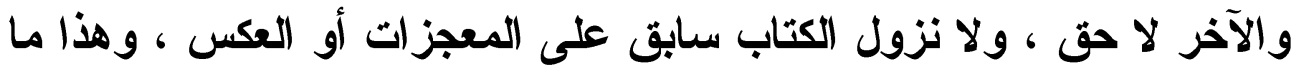
أثثاره النحويون في إفادة الواو للترتيب ، أو عدم إفادتها له.

(1) سورة آل عمران آية £^1 ، قرأ ابن عامر (بالبينات وبالزبر) وكنلك هي في مصاحف أهل

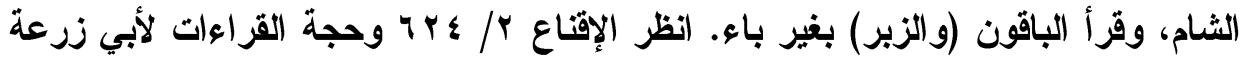

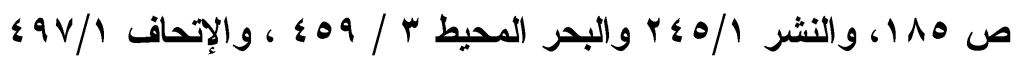




\section{الترقير الدولم \\ ISSN 2356-9050}

وقد نسب للفراء أنَّ الواو مرتبة ، قال ابن مالك : " ولا يصـ ذلــــ ،

و إلى هذا ذهب سيبويه و البصريون والكوفيون "(1).

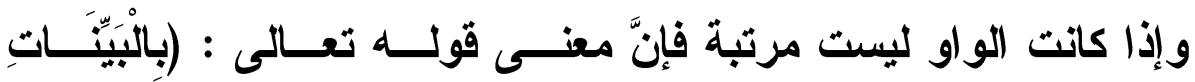

وَبالزُبُر)، أنَّ الله تعالى أنزل عليهم الكتب في مرحلة تغاير المرحلة الزمنية

التي أيدهم فيها بالمعجز ات.

رأي النحويين في عطف الاسم الظاهر على الاسم الظاهر المجرور: سبق في هذا البحث تناول موقف النحويين من عطف الاســـم الظـــاهر على الضمير المجرور بدون إعادة الجار، فهل يسري ذللك على قضية عطف الظاهر على الظاهر المجرور.

ويبدو أنَّ النحويين لم يبالوا في عطف الظاهر على الظــاهر بإعــادة الجار مع المعطوف ، أو عدم إعادته فما جاء من خلاف وما ورد من مذاهب في العطف على الضمير المجرور لم يرد في العطف على الظاهر المجرور. فالظاهر أنَّ عطف الظاهر على الظاهر وعلــى الضــمير المنصــوب المتصل يكون بلا شرط كـــام زيد وعمرو) و (إيالك والأسد)، ونحو قولــهـ

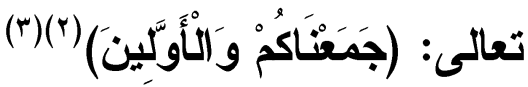

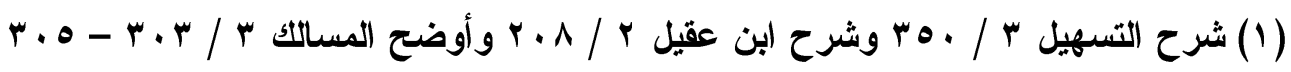

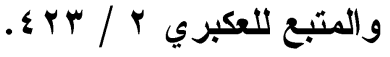

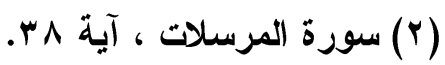

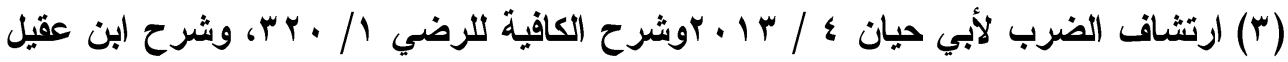

$$
. r 19-r / v / r
$$



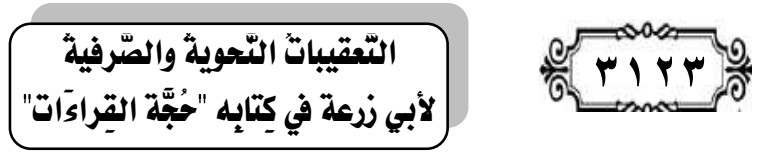

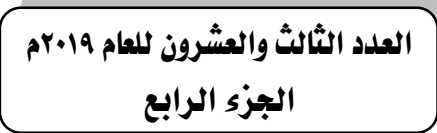

فلا خلاف يذكر بين النحويين في ذللك ، قال العكبري في شرحه لقــول

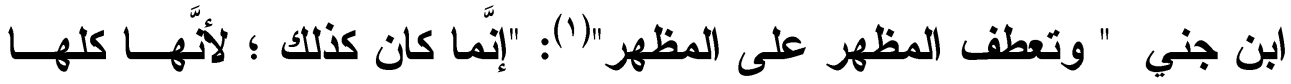

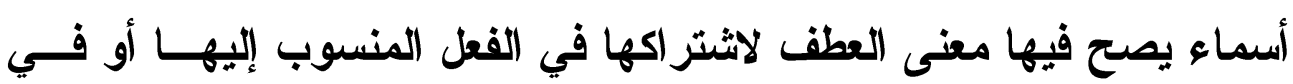

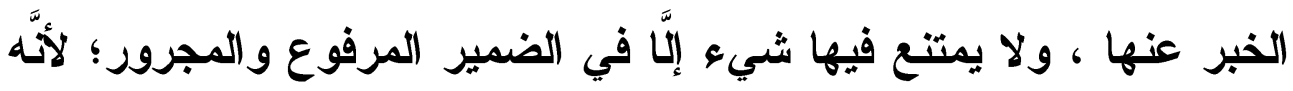

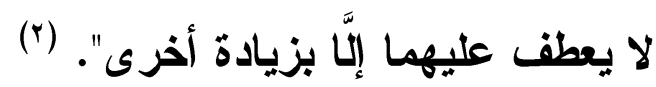

هذه الزيادة الأخرى التي أثنار إليها هي شرط العطف على كل منهما. وهذا ما رآه أيضًا أبو زرعة ، فالعطف على الظاهر المجرور ســواء

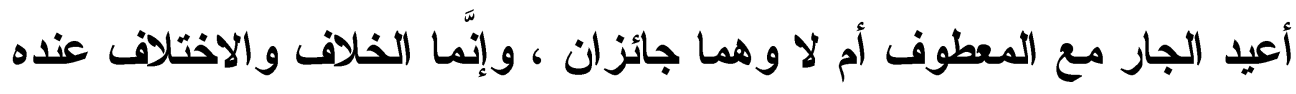

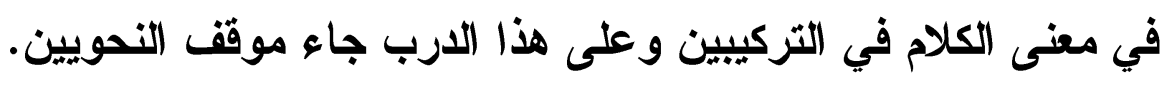

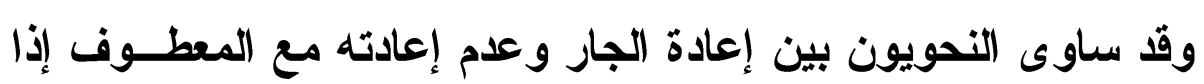
كان اسمًا ظاهرًا على اسم مجرور ظاهر، وأجازوا الوجهين. الخلاف والاختلاف بين معنى الجملة مع إعادة الجار ومعناها مع عدم

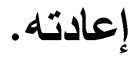

لم يكن الخلاف بين النحويين بينًا في معنى التعبيرين ومـــا ورد مــن

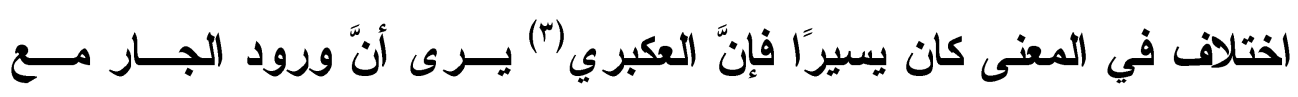

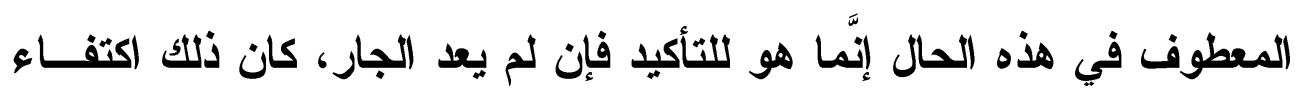
بالو او العاطفة.

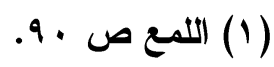

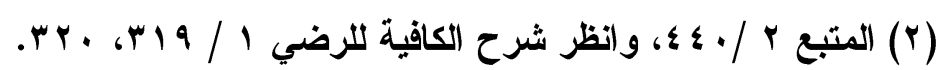

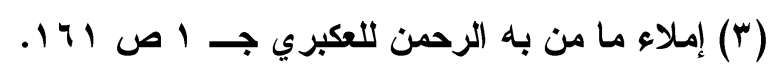




\section{الترقير الدولخ}

ISSN 2356-9050

وجاء ذلك أيضًا على لسان أبي حيان أنَّ الفارق بين المعنيين أنَّهـ مــع

الجار يكون المعنى مؤكدًا ، ولا تأكيد مع عدم وروده(').

مناقشة رأي الخليل :

بينت هذه القضية عند أبي زرعة على ما أورده الخليل مع تباين بـين التعبيزين في المعنى ، وقد سبق ذكرهما في كلام أبي زرعــة كمــا ســث إيضاح ذلك وبيانه.

وما وققت عليه مما يشير إلى رأي الخليل ، هو ما ورد في كتاب سيبويه(r):

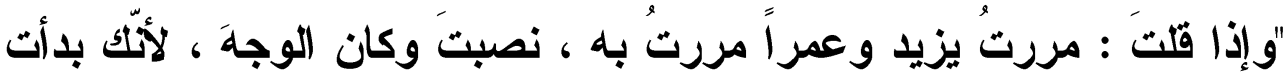
بالفعل ولم تَبتدئ اسما تَبنيه عليه ، ولكنّك قَتث: فعلت ثُ بنيتَ عليه المفعول

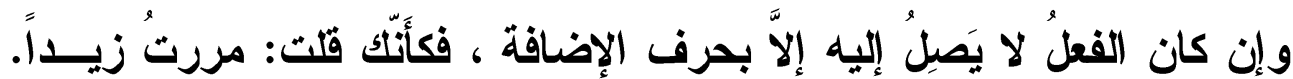
ولولا أنّه كذلك ما كان وجهُ الكلام زيداً مررثَ به، وقمتُ وعمراً مررتُ به. ونحوُ ذلك قوللك: خَشّنتُ بصدره فالصدرُ في موضع نصب وقد عملت الباء.

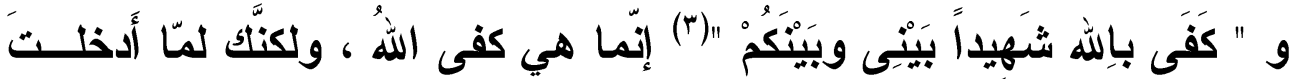

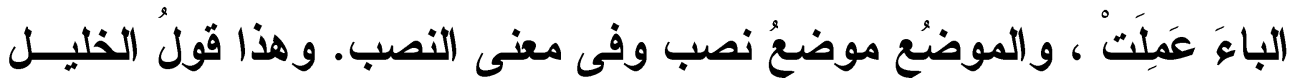

رحمه الله"(§)

فإنَّ النص يتجه إلى الناحية الإعر ابية وموضع الاسم المجرور بالباء أنَّهَه منصوب على أنَّهَ مفعول.

$$
\begin{aligned}
& \text { (1) البحر المحيط جـ r ص ص ه هـ. }
\end{aligned}
$$

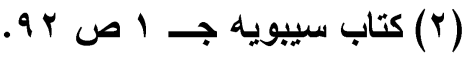

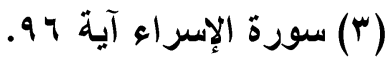

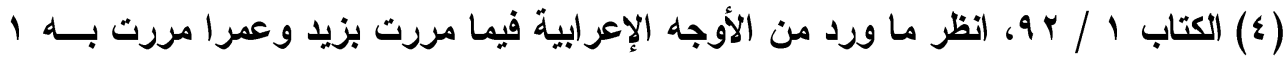

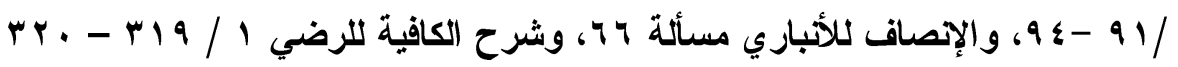




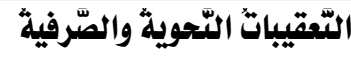
لأبي زرعة في كِتابه "حُجَّة القِراءَاتَ"
Miro

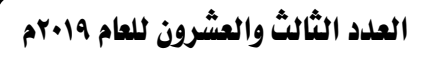

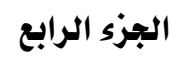

أمَّا ما يشير إلى المعنى فلا إثمارة إليه.

ونقل (بن عصفور (') عن سييويه أنَّ للواو خصوصية ، فإنَّه إذا قلت :

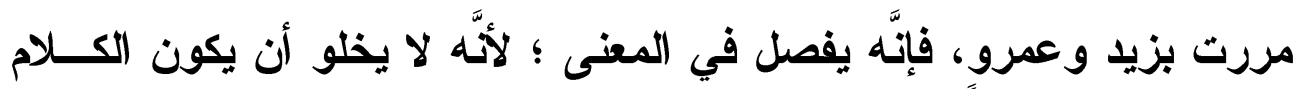

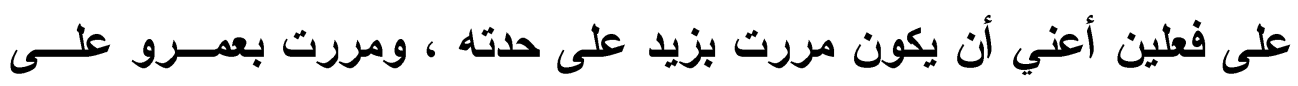

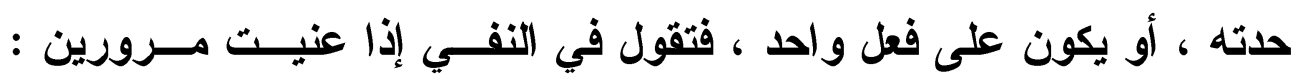

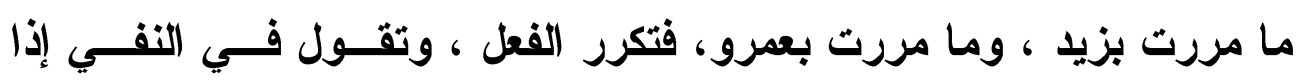

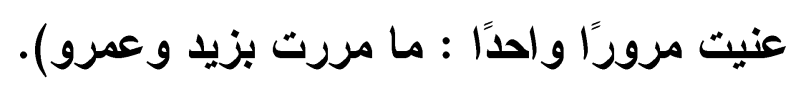

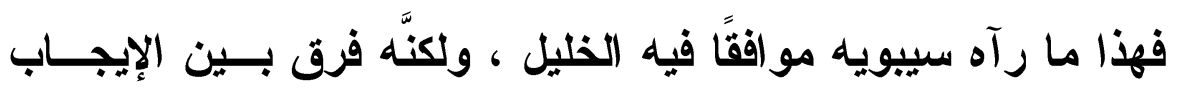

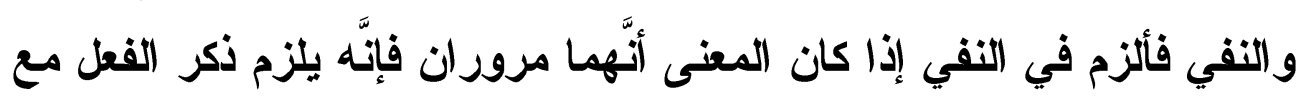

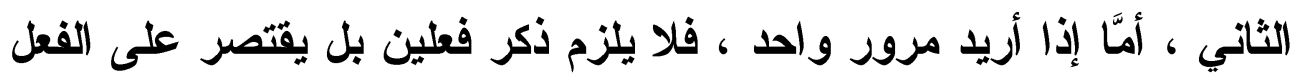
الأول.

وعلق ابن عصفور على ذلك ذاكرًا العلة في لزوم ذكــر الفعـل مـــع

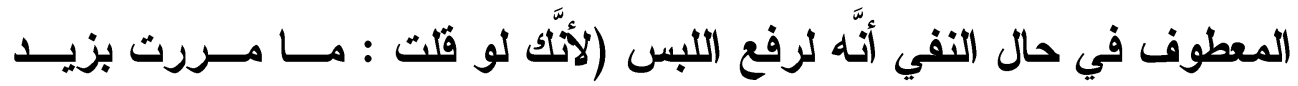

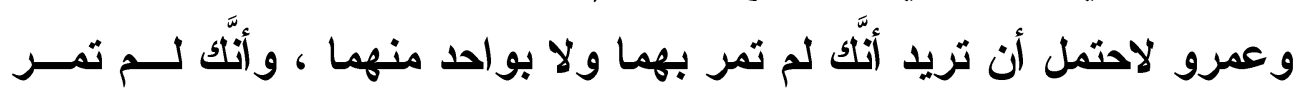

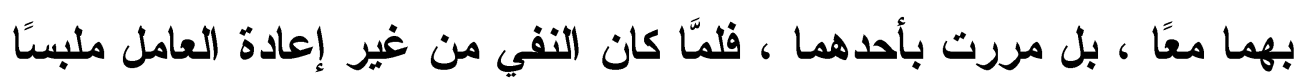
لذلك لم يكن بد من إعادة (النفي) (†). 


\section{الترقيم الدوله \\ ISSN 2356-9050}

أمَّا الشاطبي(1) فقد تناول اختلاف المعنى بين التعبيرين في حديثه في باب النعت ومَنَّل له بــ مررت بزيد وعمرو العاقلين.

فقد بين أنَّ ( العاقلان ) فيهما في العطف وبـين أن يعمـل فيهمـــا عاملان في المعنى.

أمَّا المازني (ז) فلم يوافق سيبويه في اختلاف المعنى في المرورين. وردَّ عليه فقال:(ولو قال : مررث بزيد ومررث بعمرو كان نفيه مـــا

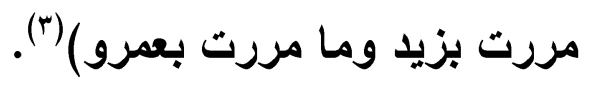
وذذا ما أورده أيضًا أبو زرعة قائلاً ذلك عن الخليل .

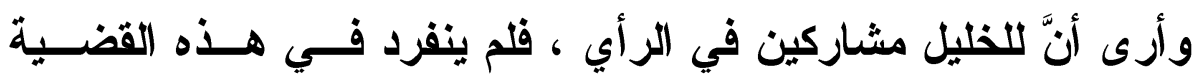
بملاحظة الاختلاف بين التركيبين مع إعادة الجار وعدم إعادته.

(1) شرح الثاطبي لأفية ابن مالك المسمى المقاصد الثافية في شرح الخلاصة الكافيـة ؛ /

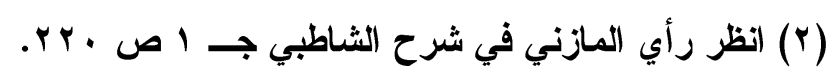

(r) النكت في تفسير كتاب سيبويه وانظر حاثية ابن حمدون على شرح المكودي لألفية ابــن

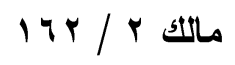


التققيباتُ التّحويثة والصّرفية

لأبي زرعة في كِتابه "حُجَّة القِراءَات"
Pirv

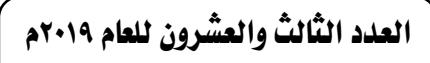

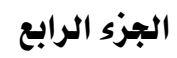

\section{r - تشديد (لكن) وتففيفها .}

قال أبو زرعة :" اعلم أنَّ لكنَّ كلمة تحقيق ، ولكنْ بالتخفيف كلمــة

استدر الك بعد نفي تقول : ما جاء عمرو ولكنْ زيدٌ خرج "(1). ما تضمنه كلام أبي زرعة :

1 - ذكر أبو زرعة هنا رأيه معقبًا على القراعات الواردة في قوله تعـالى:

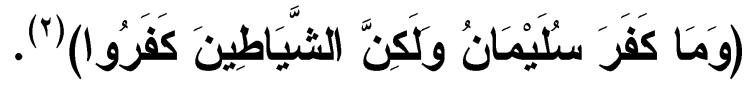
فقد ورد فيه قر اعتان :

الأولى: ( لكن ) بتخفيف النون ، وهي قراهة ابن عامر وحمزة والكسائي مع رفع كلمة الثياطين.

الثانية :(لكنَّ) بالتشديا مع نصب كلمة الثــياطين ، وهـــي قــراعة بـاقي

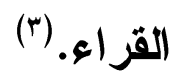

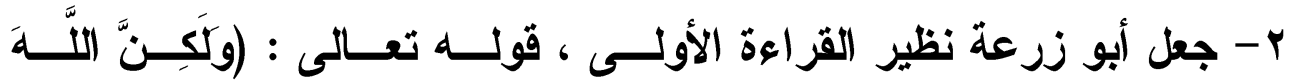

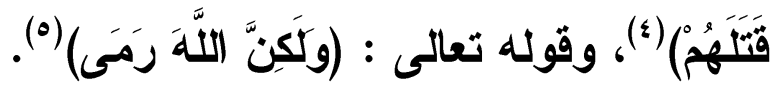
r- جعل أبو زرعة نظير القراعة الثانية ، قوله تعالى : (وكَكِـنَّ الظَّلَالمِينَ

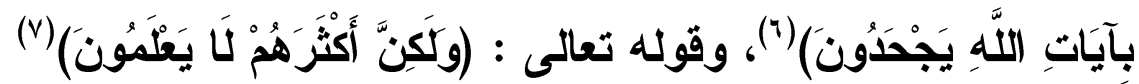

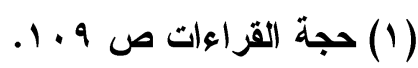

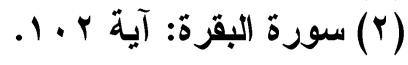

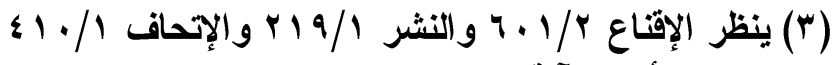

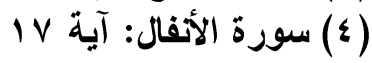

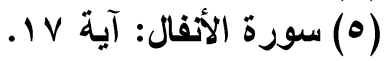

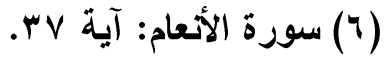

$$
\begin{aligned}
& \text { سورة الأنعام: آية V (T) سورة (V) }
\end{aligned}
$$




\section{الترقير الدولخ \\ ISSN 2356-9050}

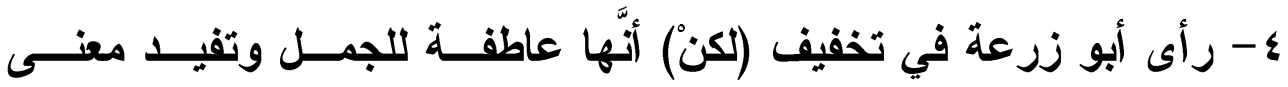

الاستدر الك ، وقد وقعت هنا بعد نفي وعطفت الجمل ، ووقعت تالية للواو. ه- لم يبين أبو زرعة نوع الواو الواقعة قبل لكن المخفقة ، فلم يظهر رأيه، ما إذا كانت الواو عاطقة أم زائدة.

צ- مثَّل لذات القضية من خارج القرآن بقولهم : (ما جاء عمرو ولكنْ زيـــ خرج)، فقد وقعت لكنْ المخففة بعد الواو، وعطفت جملة على جملة وتقــدم نفي في الكلام. - وجَّهُ أبو زرعة قر اعة تشديد (لكنَّ) في الآية بأنَّها من حيث المعنى تفيد

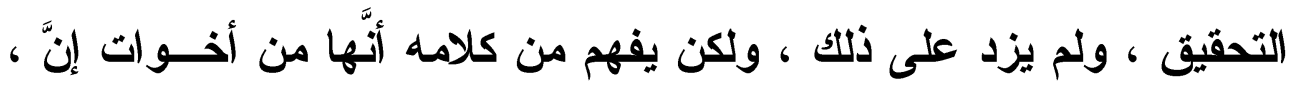
فإنَّ معنى التحقيق والتوكيد عند البعض لا يكاد يفارق إنَّ وجميع أخواتهـــا على ما سيأتي. انتهى بيان مفهوم كلام أبي زرعة ودوري هنا أن أتلمس خطــاه فــي عرض هذه القضية كالتالي: أولاًا : رأى (لنحويبن في تخفيف (لكنَّ) .

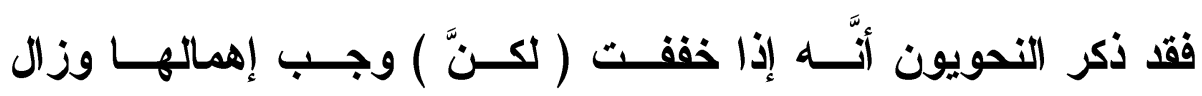

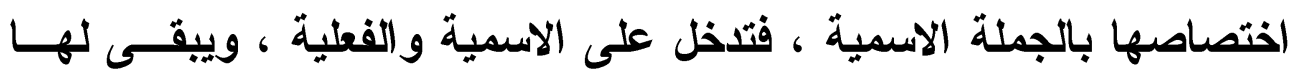

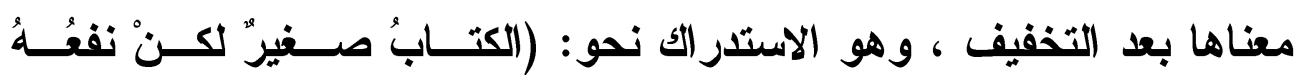

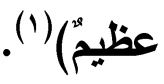


التّقيباتُ التّحوية والصّرفية

لأبي زرعة في كِتابهه "حُجَّة القِراكَاتِ"

وأجاز يونس والأخفش إعمالها قياسًا على ما خفف مـن إنَّ ، وأنَّ ،

$$
\text { وكأنَّ، فأجاز أن يقال : قام زيدٌ لكنْ عمرًا لم يقم ('). }
$$

ولكن ما ذكر اه ليس مسموعًا ولا يقتضيه القياس لزوال اختصاصــهـا

$$
\text { بالجملة الاسمية فلم يعد لها عمل (؟). }
$$

ويرى المالقي أنَّ إعمال (لكن) بعد التخفيف شاذ قال :" فإن كان ذلـــــ

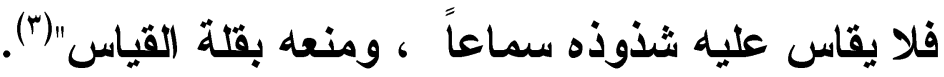

ومن شواهد (لكنْ) المخفقة وإبطال عملها ما سبق أن ورد في كـلام

أبي زرعة.

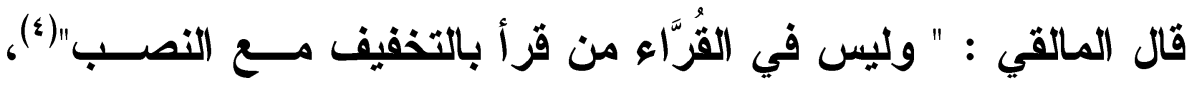
فهي لا تعمل بعد التخفيف كما سبق.

والسر في إبطال عملها زوال اختصاصها ، فتلخل علــى الإســية ،

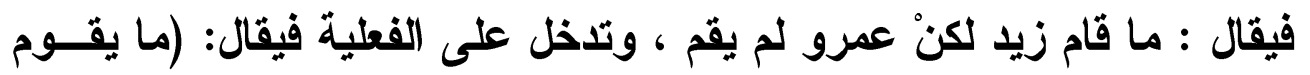
زيد لكنْ يقوم عمرو).

فهذا ما رآه النحويون في عمل (لكنَّ) إذا خفقت.

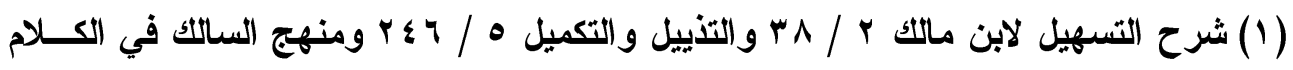

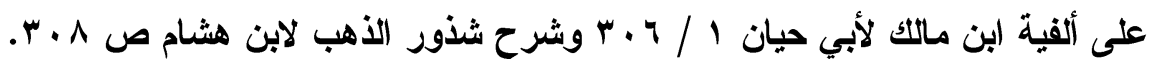

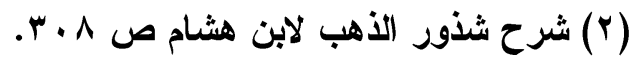

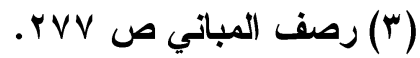

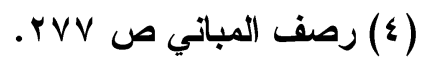




\section{الترقير الدولخ}

ISSN 2356-9050
Q.

حولية كلية اللفة العربية بجرجا مجلة علمية محكمة

\section{ثنانياً: معنهـ (لكنَّ) المشددة و المخففة .}

لكنَّ المشددة هي من أخوات (إنَّ) كما سبق ، وهي تفيد الاســتدرالك ،

وهذا المعنى مصاحب لها في تشديدها وبعد تخفيفها.

أمَّا إطلاق أبي زرعة على أنَّها للتحقيق وهي مشددة ، فإنَّما هو مـنـ قبيل أن (إنَّ) وأخواتها لا يفارقها التأكيا والتحقيق بجانب ما يفيده كل حرف من الأحرف الستة من معنى ينفرد به عن الآخر.

فقد ذهب الكوفيون والزجاجي (1) إلى أنَّ (كأنَّ) تكــون للتحقيـث ، أو

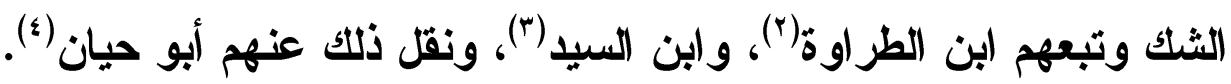
ثالثًاً : وقوع (لكن) بعد النفي أو الإيجاب وأثر ذلك في نوعها ومعناها و عملها.

لكنَّ التي تفيد الاستدر الك والعطف لا يجوز أن تقع بعد إيجاب ، فمحال عند سيبويه أن يقال : (مررت برجل صالح ولكن طالح). قال :"لأنَّ لكنَّ لا استثدر اكك بها بعد إيجاب ، ولكنَّها يثبت بها بعد النفي وإن شئت رفعت فابتدأث على هو فقتث : ما مررت برجـل صــالح ولكـنـ

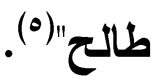

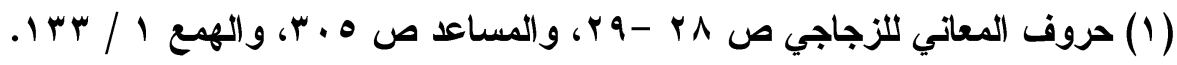

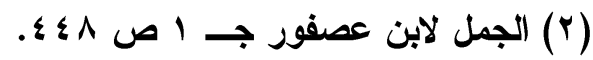

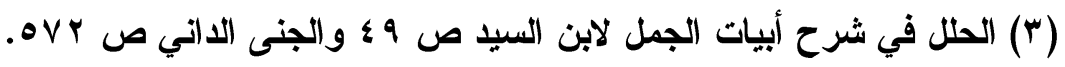

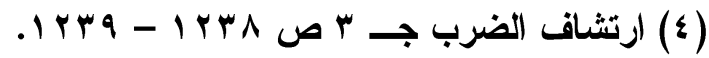

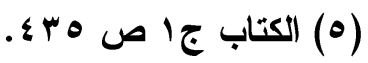



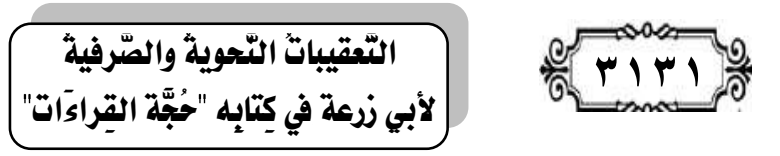

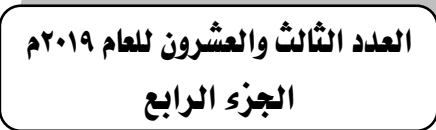

وقصر الزمخثري إفادتها للاستدرالك على عطف المفرد على المفــرد إذا وقعت بعد النفي خاصة ، كقولهم : ما رأيت زيدًا ولكن عمرًا.

فإذا جاءت لعطف الجملتين فهي للإضر اب وليست للاسـتـار الك مثلهـ

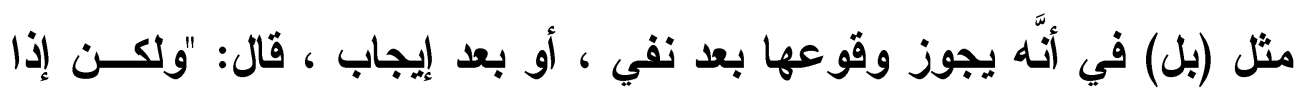

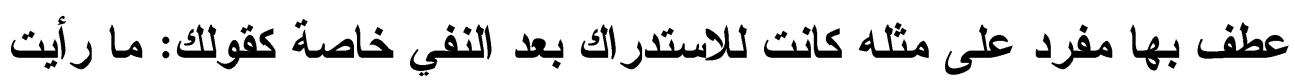

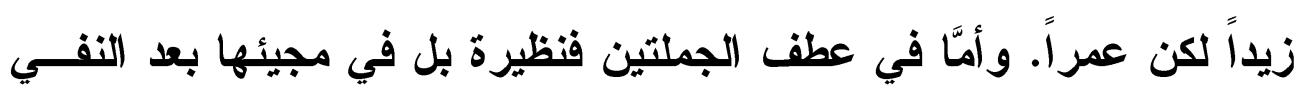

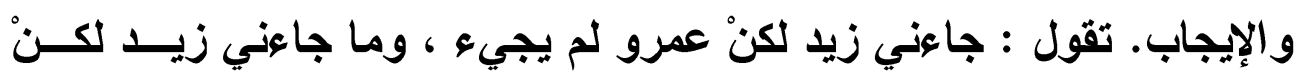
عمرو قال جاء "(1).

فهي مفيدة للاستدرالك مع عطف المفرد على المفرد في النفي خاصــة ومفيدة للإضراب مع عطف الجملة على الجملة مع النفي ، أو الإيجاب. أمَّا ابن مالك فيرى أنَّها إذا وقعت بعد نفي ، وعطقت مفرد على مفرد،

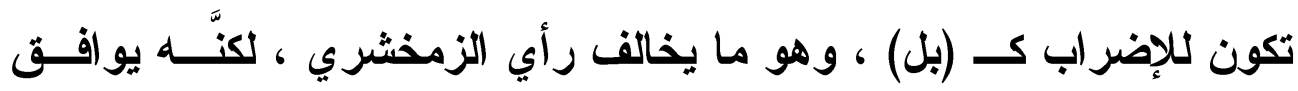
رأي أبي زرعة.

ولخص ابن هثام ما جاء في معنى (لكنَّ) بالتثنديد وعملها في ثلاثة أقوال:

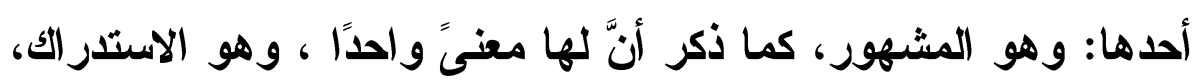

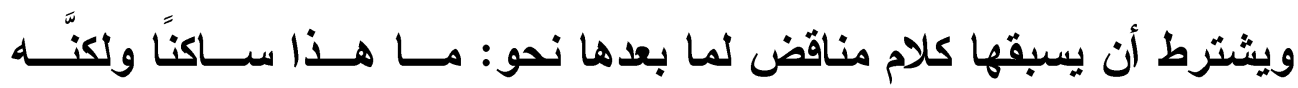
متحرك(r).

الثثاني: أنَّها ترد تارة للاستدر الك ، وتارة للتوكيد (وهذا هـو المعنـى (الأي قصده أبو زرعة في كلامه).

(1) المفصل ص ه . r.

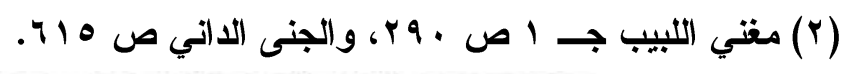




\section{الترقير الدولخ}

ISSN 2356-9050

وفسروا الاستدر الك بأنَّهُ رفع ما يتوهم ثبوته نحو: ما زيا شجاعًا لكنَّه

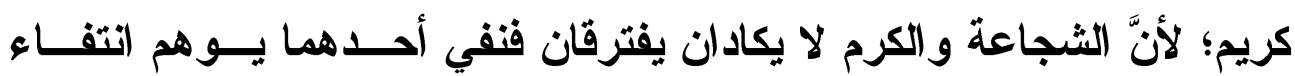
الآخر، وما قام زيد لكنّ عمرًا قام.

ومثلوا للتوكيد بنحو: (لو جاعني أكرمته لكنّه لم يجيء)، فأكــدت مــا أقادته لو من الامتناع.

الثالث : أنَّها للتوكيد دائمًا مثل (إنّ) ويصحب التوكيد معنى الاستدر (ك،

وهو قول ابن عصفور في شرح الجمل (').

ما زلت في بيان معنى (لكن) بالتشديا ، أو التخفيف سواء وردت بعد نفي ، أم إيجاب ، وسواء عطقت مفردًا على مفردٍ أم جملة على جملة. وفهمت مما سبق أنَّ (لكنّ) لا تقع إلَّا بين متناقضين بوجه ما ، فــإن كان ما قبلها نقيضاً لما بعدها ، فلا بـ من توسطها بين كلامين متغايرين نفيًا و إيبابًا.

فتستدرك بها النفي بالإيجاب والإيجاب بالنفي ، وذللك قوللك: (ما جاعني زيل لكنّ عمرًا جاعني)، و (جاعني زيد لكنّ عمرًا لم يجيء) فيتغاير المعنـى

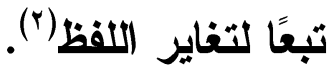


التققيباتُ التّحويثة والصّرفية لأبي زرعة في كِتابه "حُجَّة القِراءَاتَ"
Pin r I T M

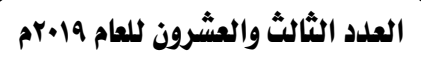
الجزء الرابع

\section{رابعاً: : نوع (لكن) إذا وقعت بعد الواو.}

$$
\text { إذا وقعت (لكن) بعد الواو فقي حكمها آراء : }
$$

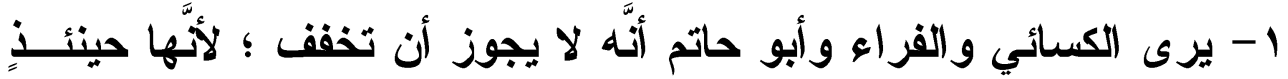

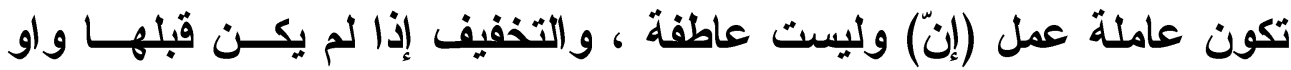

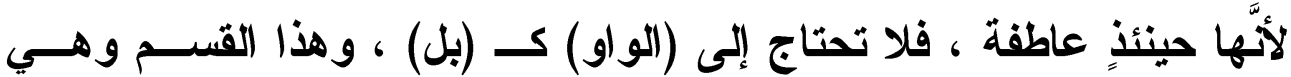

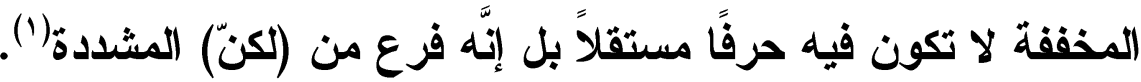

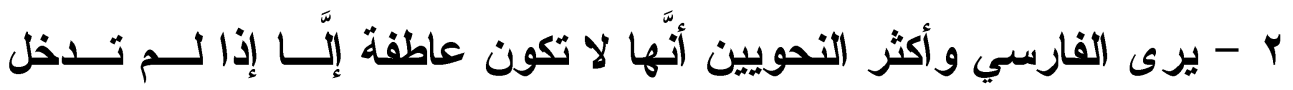
عليها الواو.

بينما ناقض آخرون هذا الكلام بالكلية فذكروا أنَّها لا تستعمل عاطفة

$$
\text { إلَّا مع الواو وتكون الواو في هذه الحالة زائدة. }
$$

وقد لا حظ ابن عصفور أنَّ سيبويه والأخفش يمثنلان للكن العاطةــة

بأمثلة وقعت فيها بعد الواو (†). r - ويرى آخرون أنَّها إذا كاتت عاطفة فأنت مخير بين أن نـأتي بــالواو قبلها أو لا وهو رأي ابن كيسان (r). بينما يرى يونس أنَّ (لكن) الواقعة بعد الواو للاستدر (لك فقط ، وليست عاطفة بل إنَّ الواو قبلها عاطفة ، وتعطف مفرد على مفرد(؛).

$$
\begin{aligned}
& \text { (1) ينظر الجنى الداني ص ONV. }
\end{aligned}
$$

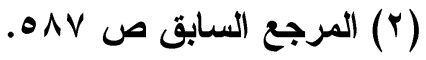

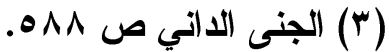

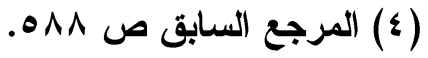




\section{الترقير الدول\$ ISSN 2356-9050}

وقد لخص هذا الخلاف الكبير في معنى ونوع وعمل (لكن) العكبـري،

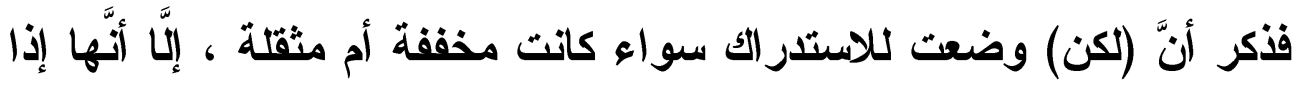

ثقلت كانت من أخوات (إنَّ) فتصب الاسم وترفع الخبر، ولا يليها الفعل(').

و إذا خفقت صارت من حروف الابتداء(؟).

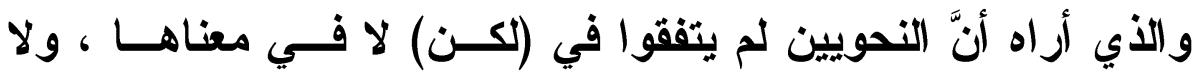

عملها، ولا نوعها في هذه القضية ، والأي استخلصته من كل ما سـبق أنَّ

أبا زرعة لخص وأوجز وأفهم في حقيقة لكن من خلال مثال أورده وهــو :

$$
\text { (ما جاء عمرو ولكن زيد خرج). }
$$

فذكر أنَّ لكن معناها الاستدر (أك ، وعطقت جملة على جملة ، ووقعت بعد الواو وسبقت بنفي. 


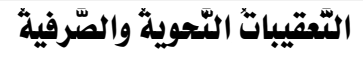

لأبي زرعة في كِتابه "حُجَّة القِراءَات"
Mimo

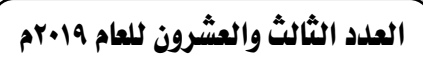

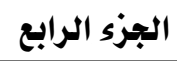

\section{بـاب النيدداء \\ إعراب " يا ابن أمَّ" في النداء}

قال أبو زرعة : (واعلم أنَّ النداء كلام محتمل الحذف فجعلوا (بن وأم شيئًاً واحداً ، وقال آخرون : إنَّهم أر ادوا الندبة بـ (ابن أماه) قالوا: والعرب تقول :(يا (بن عماه) والأصل : (يا ابن أمي) ثم قلبت الياء ألفاً فصارت (يـــا

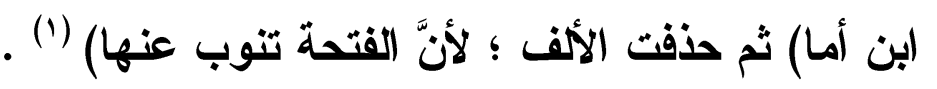
ما تضمنه كلامه من أفكار :

1 - هذا التعقيب جاء في معرض حديثه عن قراعة : ( ابنَ أمَّ ) (r) r - ذكر أبو زرعة في فتح ميم ( أمَّ ) وجهين (ّ) :

الأول : البناء على فتح الجزأين كـــ(خمسةَ عشرَ) علــى اعتبــار أنَّ (ابن وأم) كالكثمة الواحدة .

الثاني : الندبة بقولهم : يا ابنَ أماه ، والأصل : يا ابنَ أمي ، ثم حدث

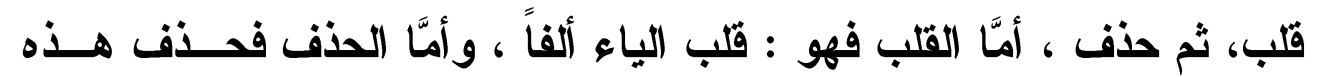
الألف ، وجيء بالقتحة لتنوب عن الألف ، فصارث : يا ابنَ أمَّم .

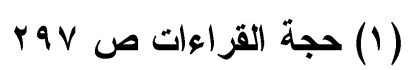

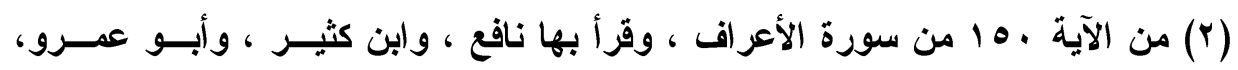

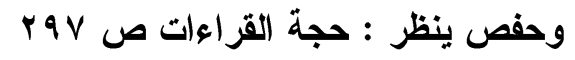

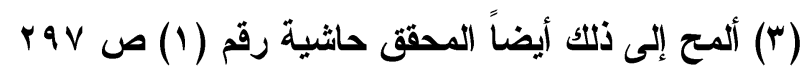




\section{الترقير الدولخ}

ISSN 2356-9050

ب - قوله : (والعرب تقول : يا ابن عماه ) يدل على أنَّ قــب اليــاء ألفــاً مسموع عن العرب ، ولعله يقصد : ( يا (بن أماه ) ، وقد يكون ما ســـع عن العرب جاء بلفظ : يا ابن عماه .

وأود هنا من دراسة قضية : ابن أم ، وابن عمَّ في النداء أن أســتظهر

الآتي:

1 - الأوجه واللغات الواردة في : أم ، وعم ، إذا أضيفا إلى ياء المتكلم . r - نوع حركة الميم من : أم ، وعم ، بين الإعراب ، والبناء . r - حذف ياء المتكلم منهما في النداء بين السماع ، والقيــاس ، ويتضــح

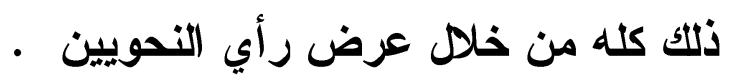
ع - توجيه قراعة : ( يا ابنَ أمَّ ) بفتح النون والميم . وأفصّل ما أجمل فيما يلي :

فقد ذكر النحويون أنَّه إذا كان المنادى مضافاً إلى مضاف إلى الياء فلا بل من ثبوت ياء المتكلم في المضاف إليه نحو: يا ابن أمي ، ويا ابن خالي . وقا اتفق النحويون على أنَّه نظراً لكثرة استعمال ابن أم ، وابن عم استثيا من هذه القاعدة ،لأنَّ النداء لـم يقع على هذه الأسماء ، الأب والأخ واليــاء إنَّما تحذف إذا وقعت موقعاً يحذف فيه التنوين بأن تتصل بالاسم المنادى(") وذكر النحويون هنا أوجهاً كلها مسموعة عن العرب :

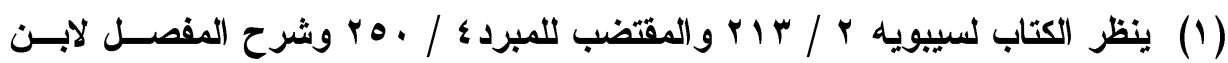

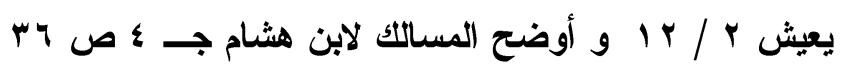




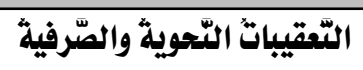
لأبي زرعة في كِتابه "حُجَّة القِراءَات"
Mirv

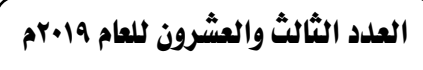

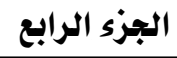

الوجه الأول : إثبات الياء ومنه قول الثاعر : (1)

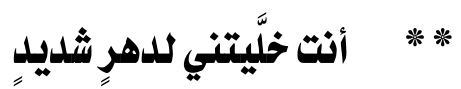
يـا ابن أميِّ ويسا شُقِقِقَ نَفَسي الوجه الثاني : حذف الياء وفتح الميم يقال: يا (بن عمَ ، ويا ابن أمَ . الوجه الثالث : من الأوجه الجائزة في : ابن أم ، وابن عم كسر الميم علـى المى إضافة ابن إلى أمي أو عمي ، ثم حذفت الياء من الثاني ويقي الكسر . الوجه الرابع : أن يقال : يا ابن أما ويا ابن عما ـ بقلب الياء ألفاً وبقائهــا دون حذف وقلب الكسرة فتحة تخفيفاً . رأي النحويين في نداء : ابن أم ، وابن عم ، بين السماع والقياس . ما سبق من أوجه ذكرها النحويون على الإجمال ، أمَّا عن التفصيل فأعرض

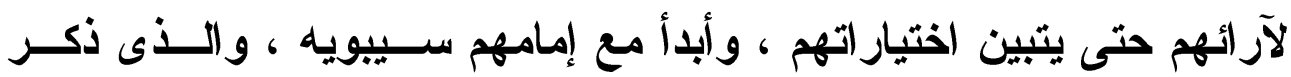

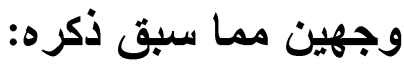
الأول : فتح الجزأين على التركيب . الثاني : فتح ابن ، وكسر الميم من "أم" على التركيب أيضاً .

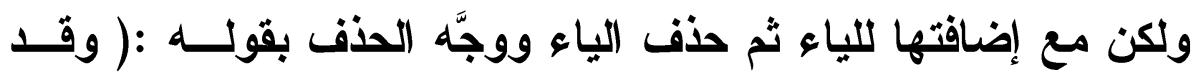

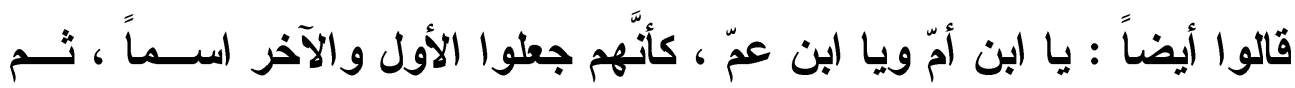

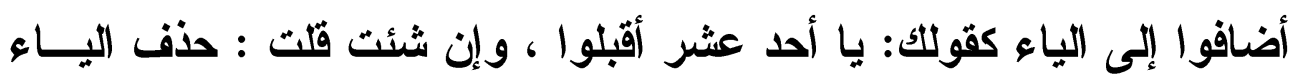

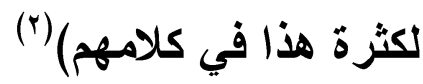

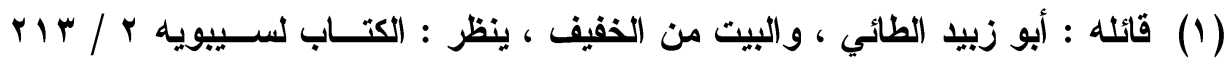

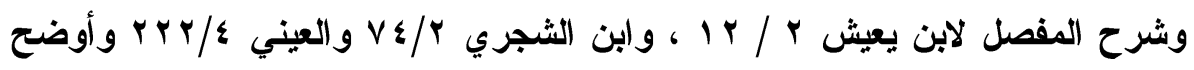

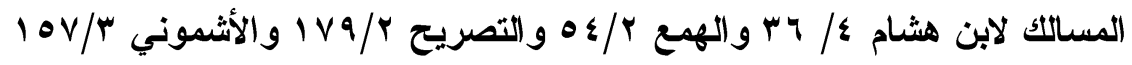

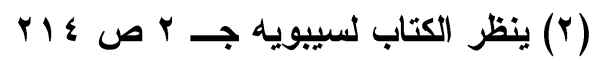




\section{الترقيم الدولخ}

ISSN 2356-9050
का
حولية كلية اللفة العربية بجرجا موبمة مجلة علمية محكمة المية

وقد صرح سبيويه بأنَّ كلا الوجهين مسموع مقيس (1)

أمَّا المبرد فقد أيَّد ما ذكره سبيويه ، وعلل ذلك بكثرة الاستعمال قـال : ( ألا تزى أنَّ الرجل منهم يقول لمن لا يعرف ولمن لا رحم بينه وبينه : يا ابـن

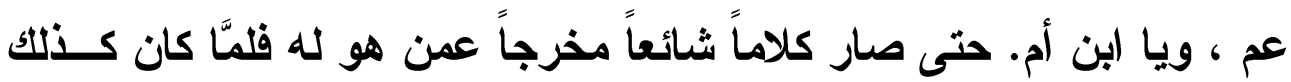

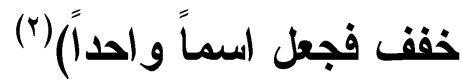

وذكر العكبري)(ّ) الأوجه التي وردت في "أم" جميعها ، واستشهـ (بـن

مالك (\&) بثبوت الياء بقول الشاعر :

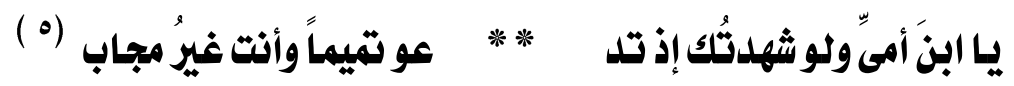

واستثهر لثبوت الألف بقول الشاعر (†) :

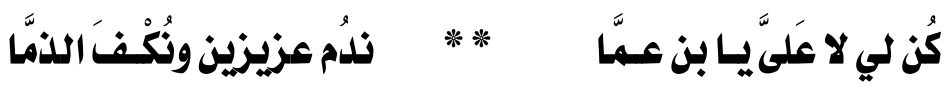

أمَّا الأثثموني فقد ذكر أنَّ البعض يذهب إلى أنَّ الكسر في الميم أجود

من الفتح(v)

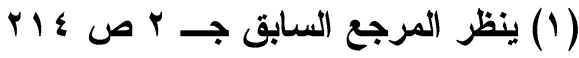

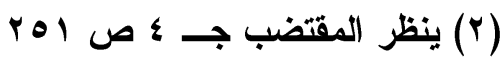

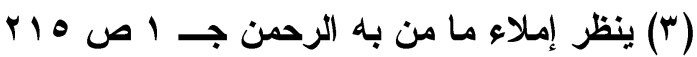

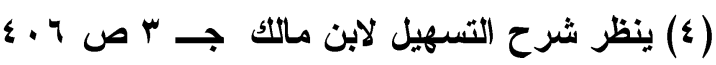

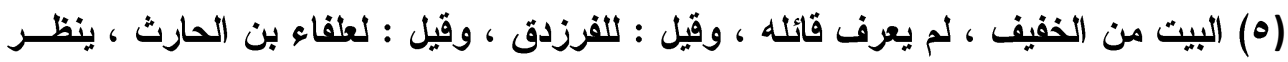

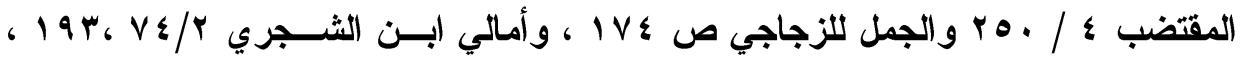

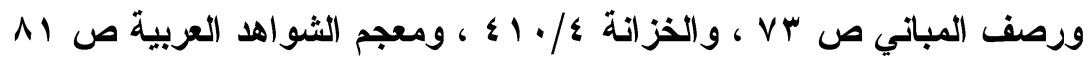

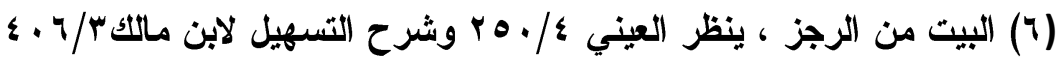

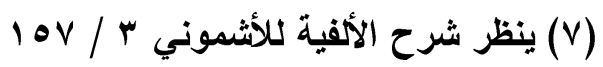

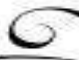




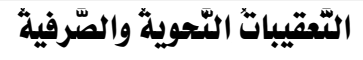
لأبي زرعة في كِتابهه "حُجَّة القِراكَاتِ"
$0 \longdiv { p i p q }$

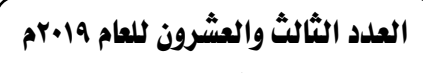

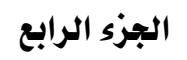

وذكر الصبان أنَّ البعض يرى أنَّ قلب الياء ألفاً أجود من إثباتها · (1) أمَّا الوجه الأى ذكره أبو زرعة من جواز : يا ابن أماه. على الندبة فلم أجد من ذكره في الكتب التي تيسر لي الاطلاع عليها ، ولعله مما انفرد به. توجيه قراعة ( يا ابنَ أمَ ) بفتح النون والميم بوجهين :

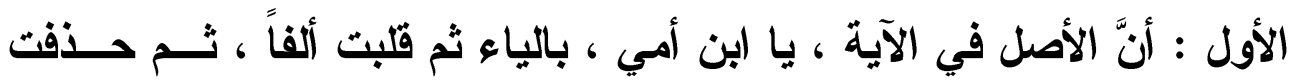

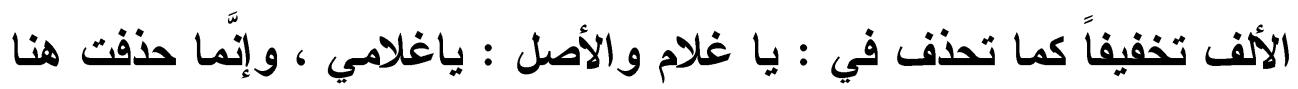
مع كون الياء متصلة بالمضاف إليه لا بالمضاف وذلك لكثرة الاستعمال .

$$
\text { وتكون الفتحة في (ابن ) فتحة إعراب لا بناء . }
$$

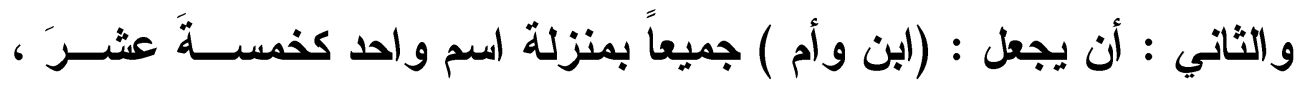

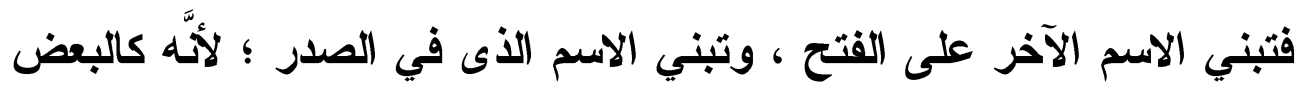

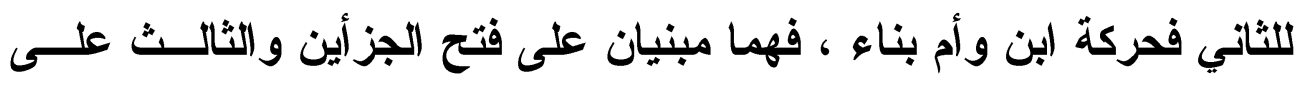
الإنباع) (لانئ)

(1) ينظر حاشية الصبان على الأشموني / 10V/r

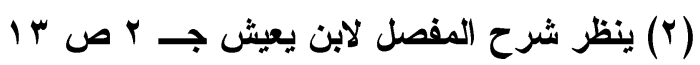




\section{الترقيم الدولم \\ ISSN 2356-9050}

\section{باب إعراب النهمل}

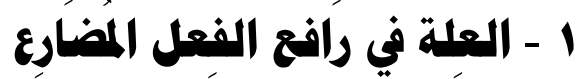

قال الإمام أبو زرعة : (واعلم أنَّ الفعل المضارع إذا حل محــل اســــ

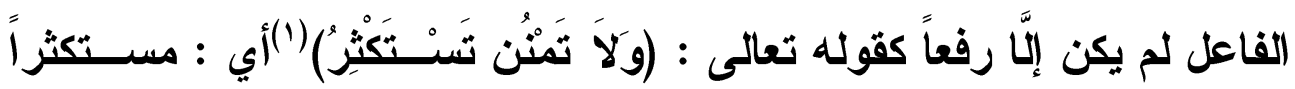

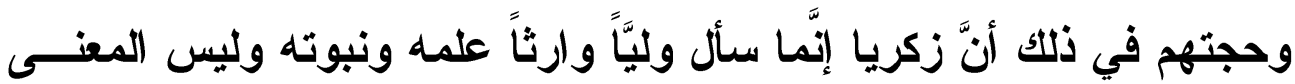
على الجزاء أي إن (وهبته ورث ) ذلك لأنَّه ليس كل ولى يرث ، فإذا لم يكن كذلك لم يسهل الجزاء من حيث لم يصح أن تقول : ( إن وهبته ورث ، لأنَّهـ قد يهب ولياً لا يرث وأخرى وهى أنَّ الآيـة قد تمَّت عند قوله :(وليـاً) ثـــ تبتلئ يرثي أي : هو يرثي ويرث من آل يعقوب)(r) . ما تضمنه كلامه من أفكار :

لم يغفل أبو زرعة قضية من القضايا النحوية المهمة ، وهي قضــية رافـع الفعل المضارع ، وقد تضمن كلامه الأفكار الآتية : 1 - ذكر أبو زرعة رأيه في رافع الفعل المضارع ، فهو يـرى أنَّ رافعـهـ وقوعه موقع اسم الفاعل .

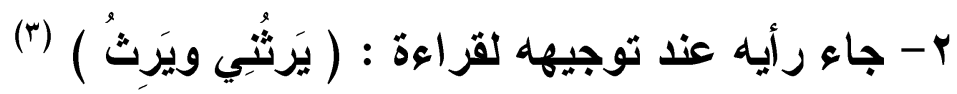

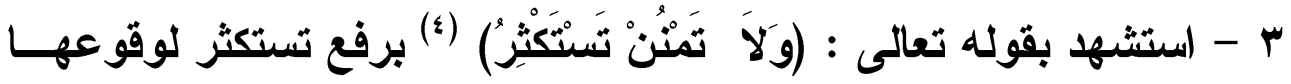
موقع اسم الفاعل (مستكثراً ) مع تقدم النهى "لا تمنن " ولم يقرأ أحــــ مــن

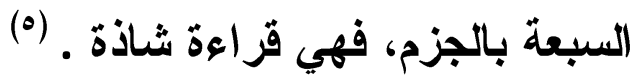

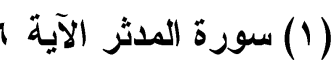

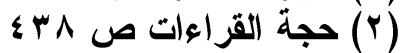

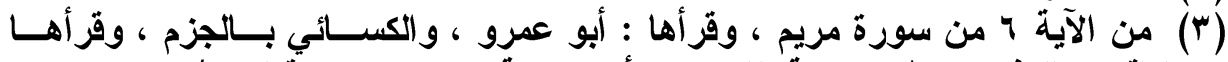

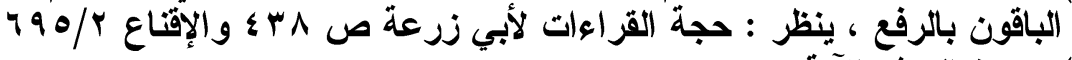
(ع) سورة المدثر الآية 7

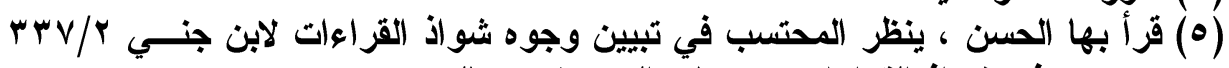

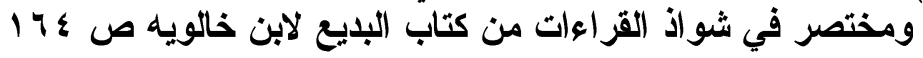




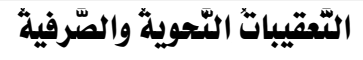
لأبي زرعة في كِتابه "حُجَّة القِراءَات"
Wis 1

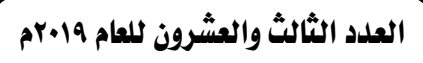

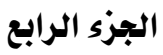

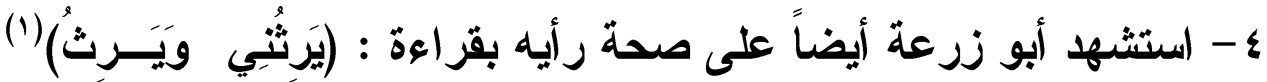

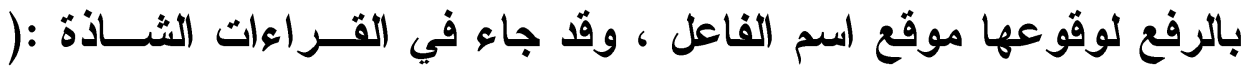

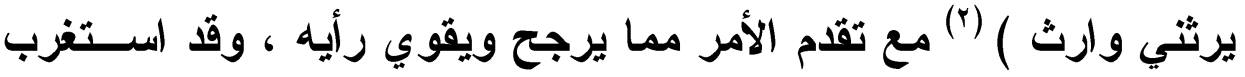
ابن جني هذه القراءة فقال : (هذا ضرب من العربية غريــب ، ومعنــاه

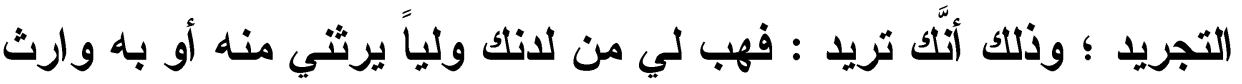

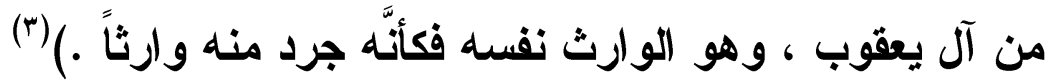

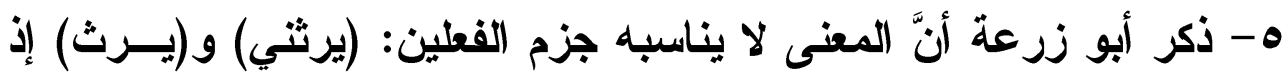

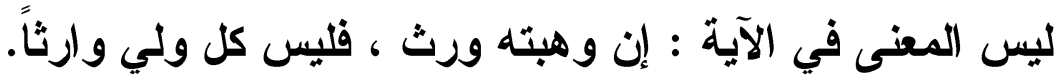
צ- ذكر أبو زرعة دليلاً آخر لرفع : يرثني ويرث ، وهو : أنَّهما وقعا فـي

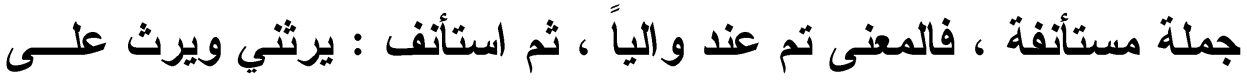

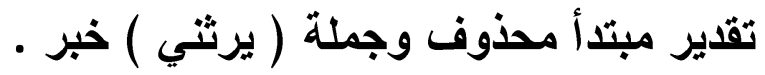
V- لم يكن أبو زرعة في قضية رافع الفعل المضارع مؤيداً مذهب الكوفيين،

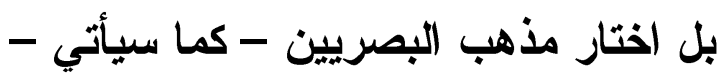
مناقثنة القضبة : تباينت مذاهب النحويين في رافع الفعل المضارع على الآتي :

(1) من الآية ז من سورة مريم ، وسبق تخريجها

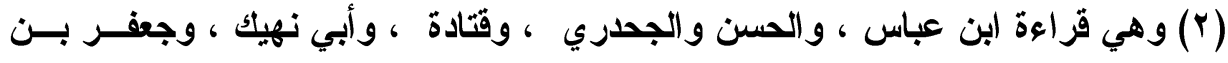

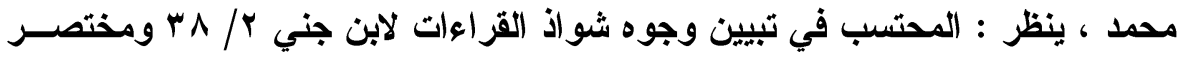
شواذ القراءات لابن خالويه ص 14

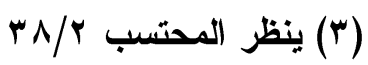




\section{الترقير الدولخ \\ ISSN 2356-9050}

الأول : وهو رأي البصريين ، أنَّ رافعه هو وقوعه موقع الاسم فالعامل إذاً

معنوي (') ملو

الثاني : مذهب بعض الكوفيين أنَّ رافعه هو تجرده من العوامل اللفظية ـ (r)

الثالث : مذهب الكسائي ومن تبعه أنَّ رافعه حروف المضارعة . (广) أمَّا عن المذهب الأول فبيانه أنَّ المضارع إذا وقع موقعاً صالحاً للاسم سواء كان الاسم في موضع رفع نحو: يقومُ زيدٌ . لأنَّ " يقوم " في موضــع

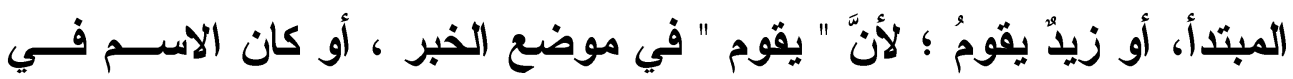
موضع نصب نحو: كان زيا يقومَ يا فتى ، وظنتت زيداً يقومَ . أو كان الاسم في موضع جر نحو: مررث برجلٍ يقوم(๕) ، (ولا يجــوز

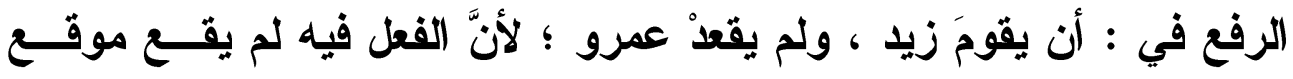

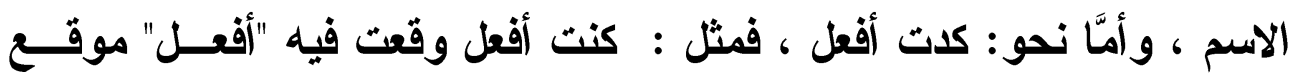
فاعل وإن لم يتكلم به) (ن) وهذا سيبويه إمام البصريين يؤكد ذلك قائلاً : (وعلته أنَّ ما عمل فـي الأسماء لم يعمل في هذه الأفعال على حد عمله في الأسماء كما أنَّ ما يعمل في الأفعال فينصبها ، أو يجزمها لا يعمل في الأسماء وكينونتها في موضــع

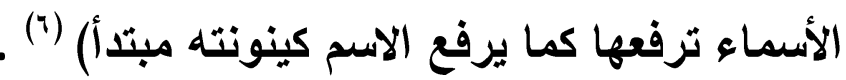

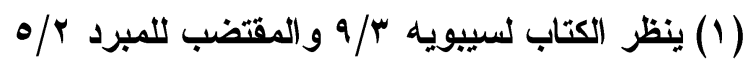

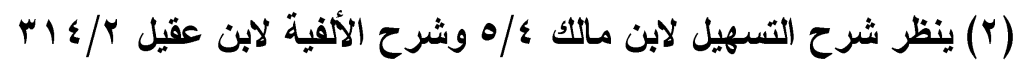

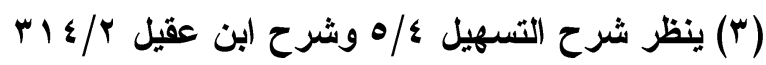

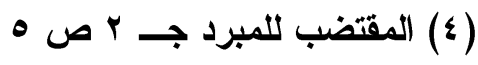

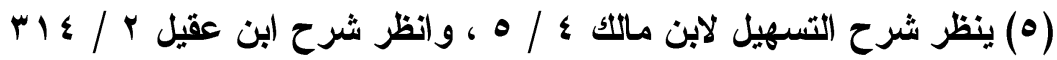

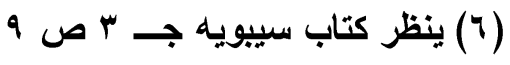


وهذا أيضاً ما أكدَّه المبرد حيث قال ذاكراً العلة في رفـــع المضــارع :

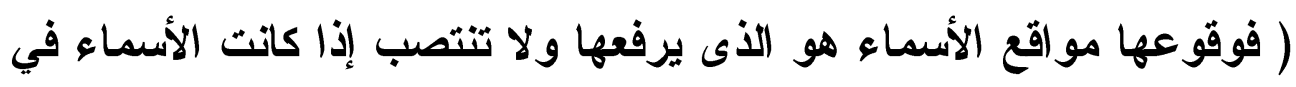

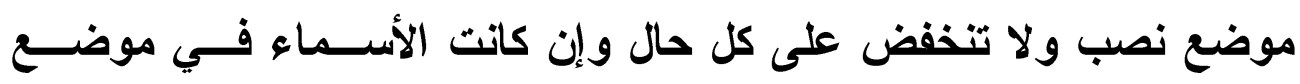

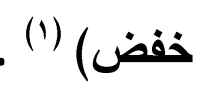

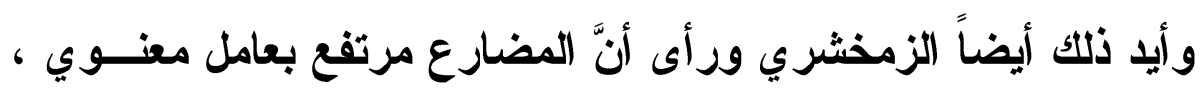

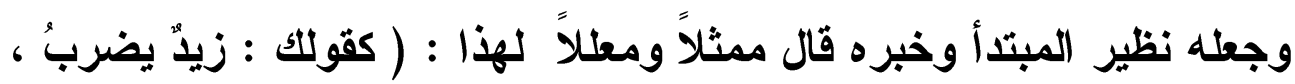

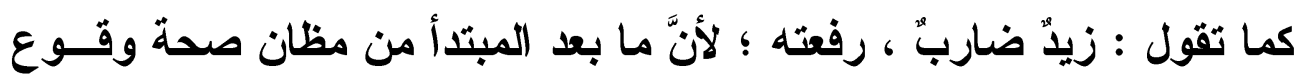
الأسماء .

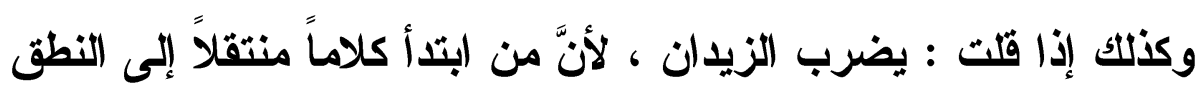

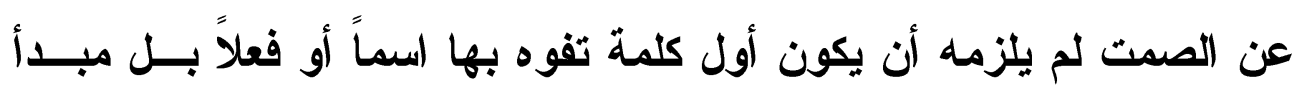
كلامه موضع خبره في أي قبيل شاء)(ن) .

هذا بعض ما قيل في القول الأول من أقوال رافع الفعـل المضـــارع ، و الأى تناوله أبو زرعة بالتفصيل والتحليل في استدر اكه . أمَّا عن القول الثاني ، والأى يرى أصحابه أنَّ رافع المضارع تجـــده مــن

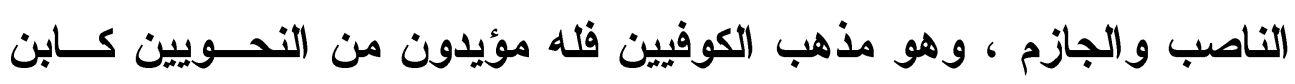

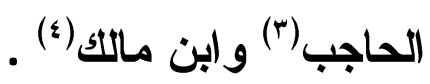

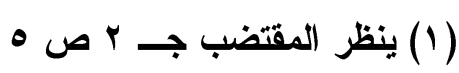

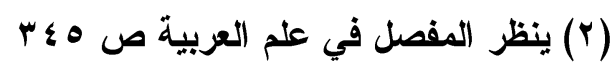

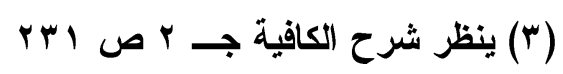

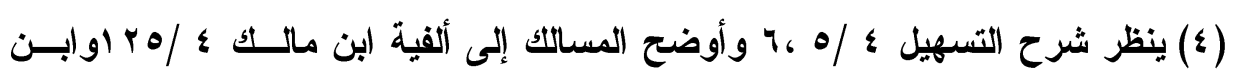

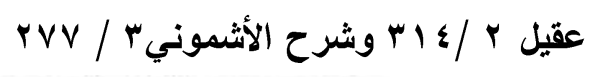




\section{الترقيم الدوله \\ ISSN 2356-9050}

واعترض ابن مالكك على ما ذهب إليه البصريون مدللاً بأنَّه لو كان كما قالوا لما ارتفع بعد الحروف المختصة بالأفعال وحروف التحضيض إذ الفعل

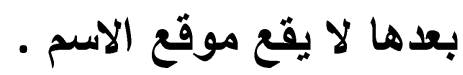

ولكن أجيب بأنَّ المر اد بموقع الاســم الموضــعـ الـــى هــو لكلاســم

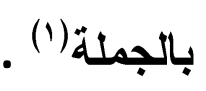

بينما نسب ابن الحاجب والأثموني للكسائي القول بأنَّ رافع المضارع هو حروف المضارعة ( لأَّها دخلت في أول الكلمة فحدث الرفع بحدوثها إذ باتئ أصل المضارع إمَّا الماضي وإمَّا المصدر ، ولم يكن فيهما هذا الرفــع بـلـل حدث مع حدوث الحروف فإحالته عليها أولى من إحالته على المعنوي الخفي

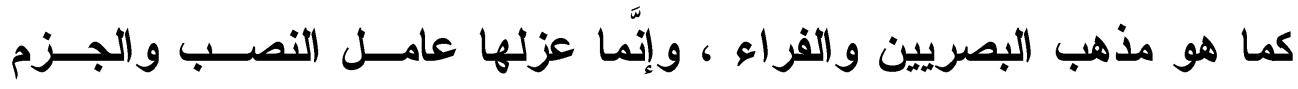

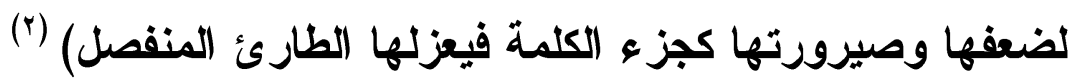

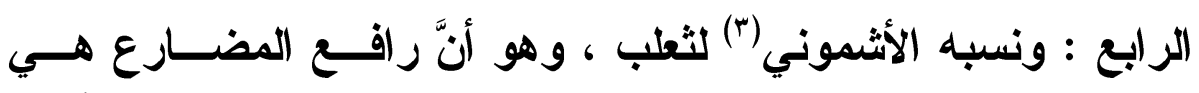

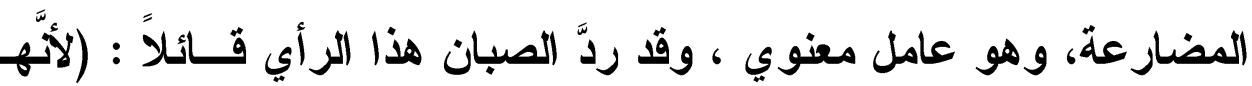

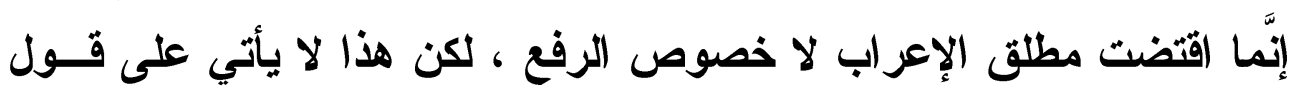
الكوفيين إن إعراب المضارع بالأصالة لا بالحمل على الاسم ومضارعه) (\&) .

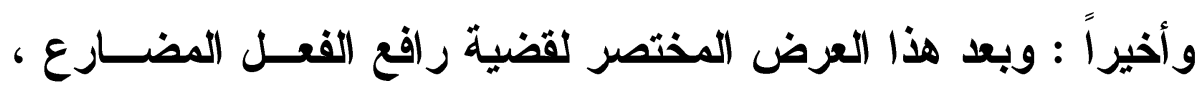
فإني أسنطيع أن أثير إلى أنَّ أبا زرعة كان مؤيداً للمذهب البصرى والـــى اتبعه أكثر النحويين .

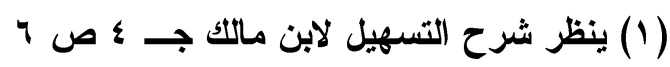

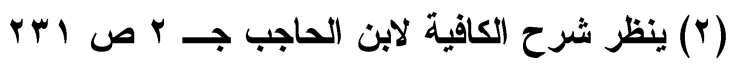

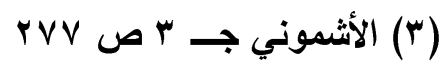

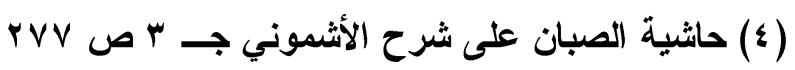




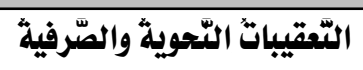

لأبي زرعة في كِتابِه "حُجَّة القِراكَاتِ" in $1 \leqslant 0$

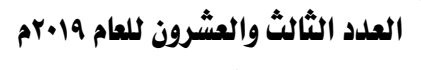

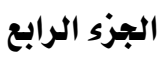

وقد أيد أبو زرعة هنا أن يكون رفع المضارع في ( يَرِثُبِي ويَرِثُ ) هو وقوع الفعل موقع اسم الفاعل وارث.

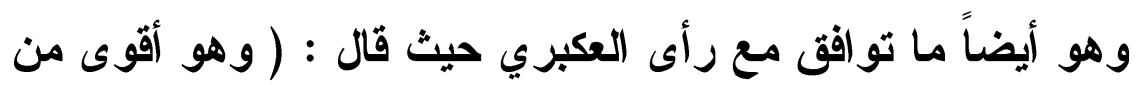

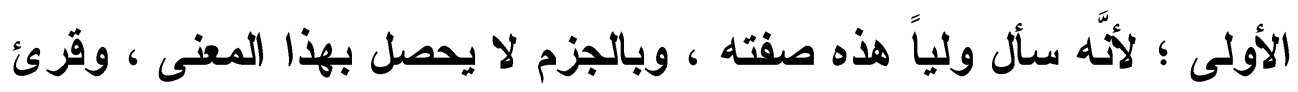

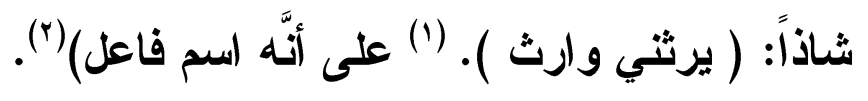
ولعل ورود قراءة بالتصريح باسم الفاعل أقوى دليل على ما ذهب إليه

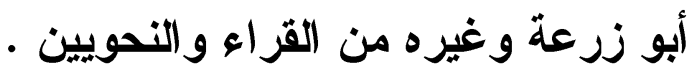




\section{الترقير الدولم \\ ISSN 2356-9050}

\section{r - أنواع "أنْ" هفتوحة الهـهزة ساكنة النون}

قال الإمام أبو زرعة : (واعلم أنَّ (أنْ) تلذخل في الكلام عـــى أربعـة

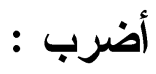

الأول : "أنْ " الناصبة للفعل وهى التي ذكرناها(1) تقول : ( أريد أنْ أخرج) . و الثاني : (أنْ) الخفيفة عن (أنَّ) الثقيلة كقول الأعشى :

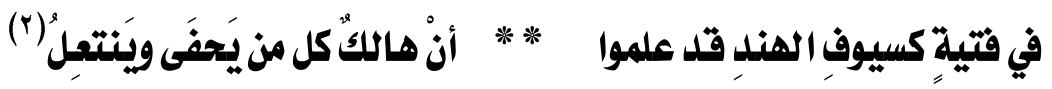

$$
\text { أر اد أنتَّه هالكك . }
$$

الموضع الثالث : أن تكون بمعنى (أي ) كقوله : (أَنِ امْثُوا) (r) ) معناه أي : (مشوا)

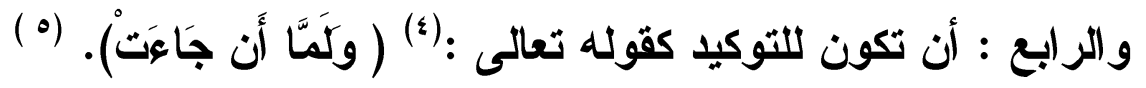
ما تضمنه كلامه من أفكار :

1 - ذكر أبو زرعة أنواع "أنْ " مفتوحة الهمزة ، مخفقة النون .

r - مثَّل أبو زرعة لهذه الأنواع الأربعة بما يوضح كل نوع منها .

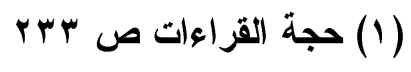

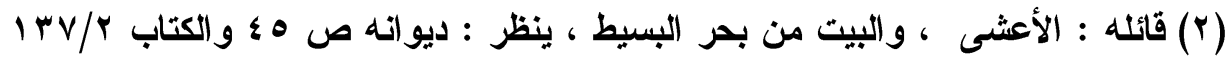

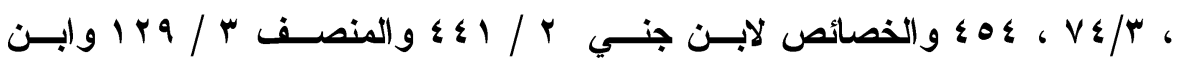

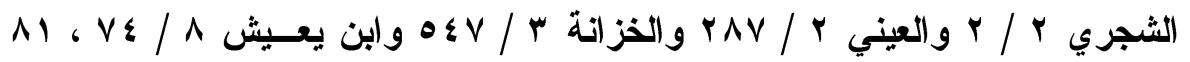

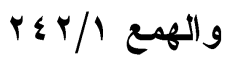

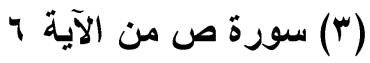

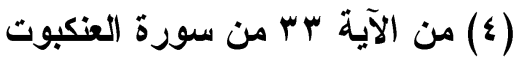

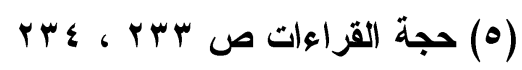




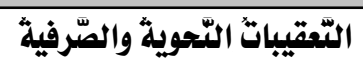
لأبي زرعة في كِتابِه "حُجَّة القِراءَاتَ"
क.

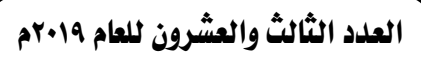
الجزء الرابع

آراء النحويين في أنواع أنْ المفتوحة المخفقة النون :

(أن) بفتح الهمزة ونون واحدة حصرها النحويون في أربعة أنواع :

النوع الأول : تكون حرفاً مصدرياً ناصباً للفعل المضارع ولها وصفان:

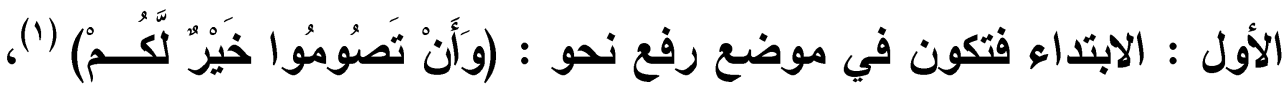

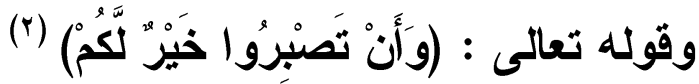

و التقدير : صيامُكم خير" لكم ، وصبركم خير" لكم .

الثاني : إذا وقعت بعد لفظ دال على معنى غير اليقين فتكون في موضع رفع

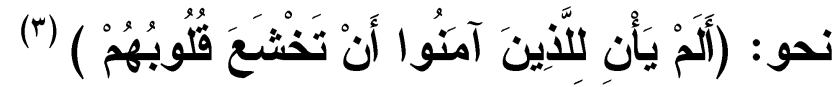

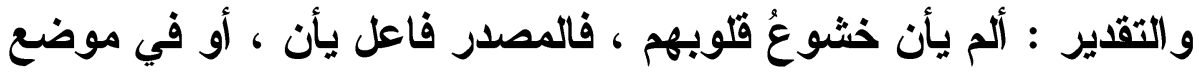

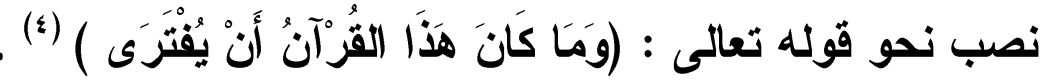

والتقدير : افتراء فالمصدر خبر كان في موضع نصب .

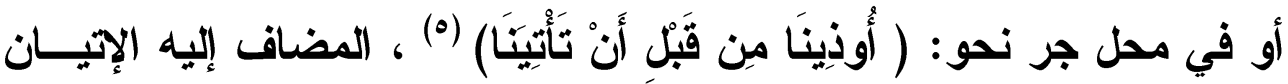

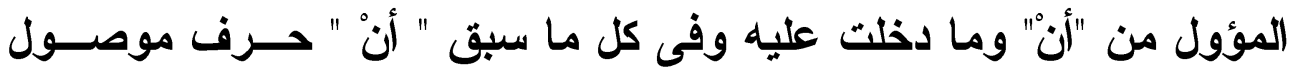

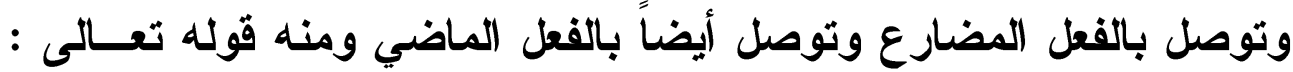

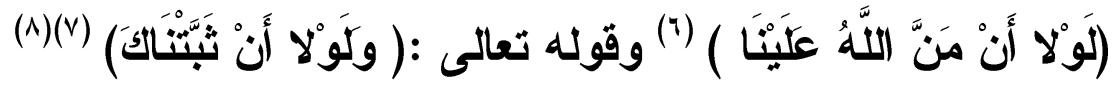

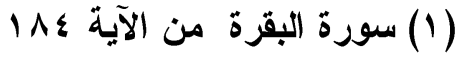

$$
\begin{aligned}
& \text { (Y) سورة النساء من الآية هورة الآية }
\end{aligned}
$$

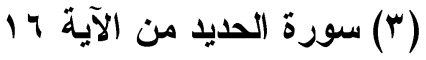

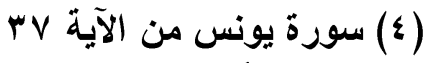

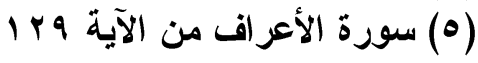

$$
\begin{aligned}
& \text { (†) سورة القصص من الآية بر الآية }
\end{aligned}
$$

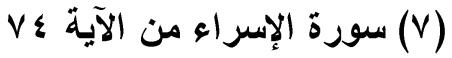

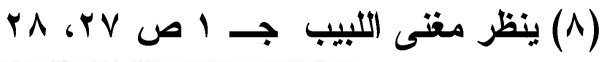




\section{الترقيم الدوله \\ ISSN 2356-9050}

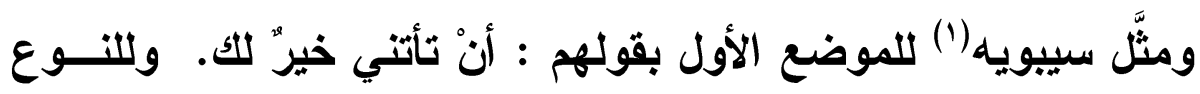

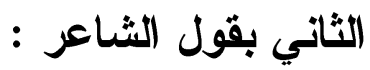

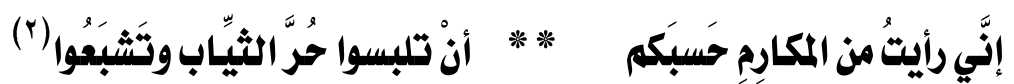

وذهب المبرد إلى أنَّها لا تقع مع الفعل الدال على الحال ؛ لأنَّها لما لا يقــع

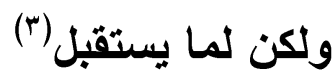

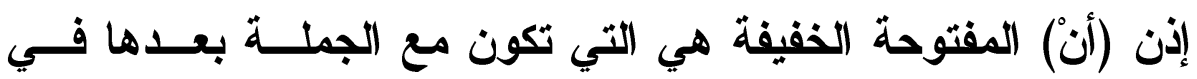

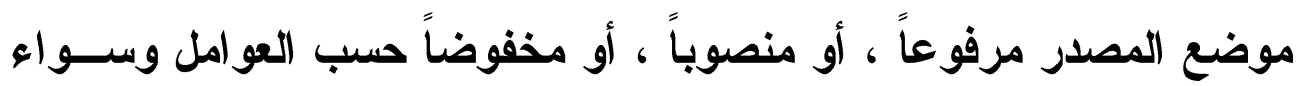

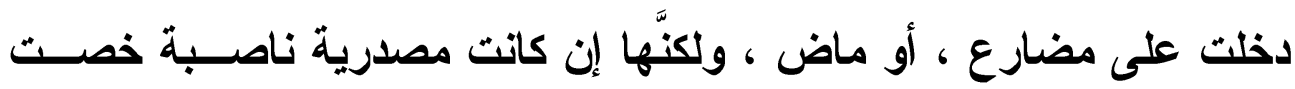

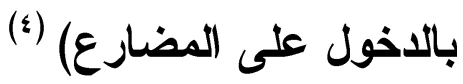

النوع الثاني : من أنواع "أنْ" أن تكون مخفقة من الثقيلة وهى التــي

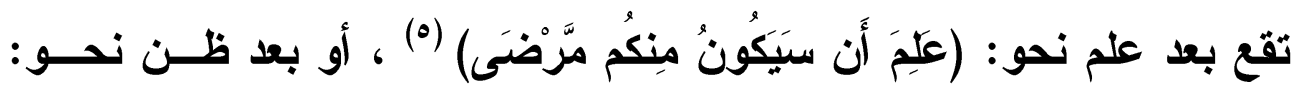

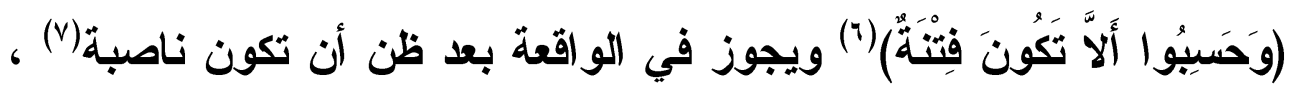

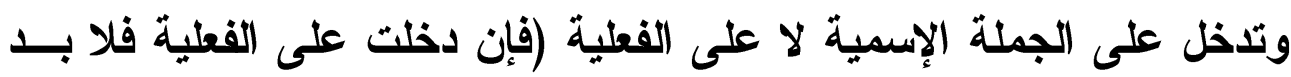

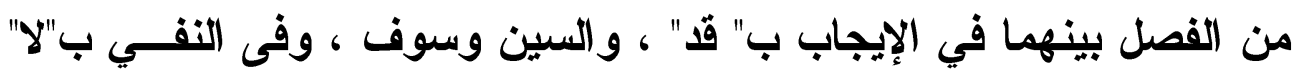

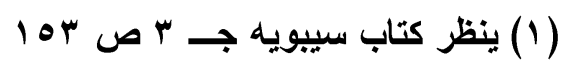

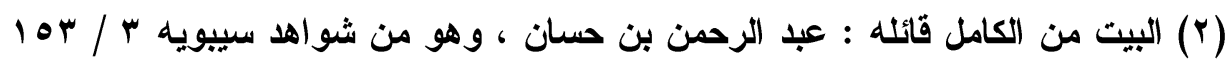

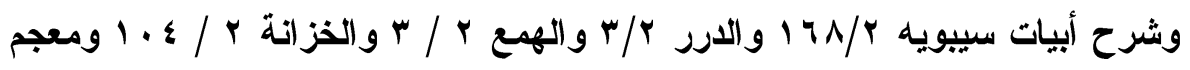

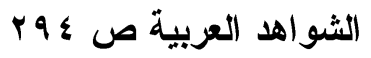

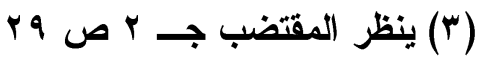

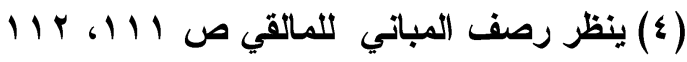

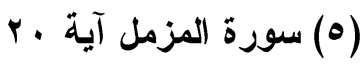

$$
\begin{aligned}
& \text { (T) }
\end{aligned}
$$

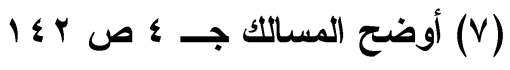




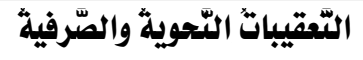

لأبي زرعة في كِتابه "حُجَّة القِراءَاتِ"

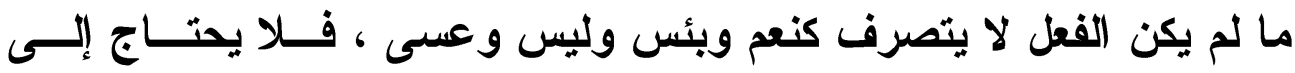

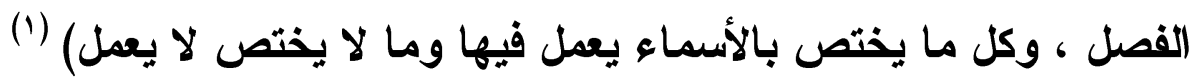

النوع الثالث : "أنْ" المفسرة وهى التي تعد عبارة وتفسيراً وتكون إمَّا

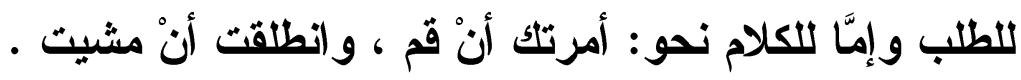

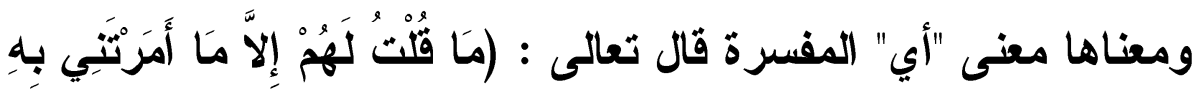

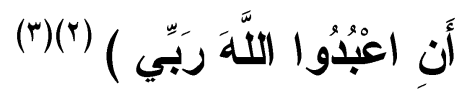

قال سيبويه : (أمَّا قوله : كتبت إليه أنْ افعل ، وأمرته أنْ قــم ـ أنَّــهـ

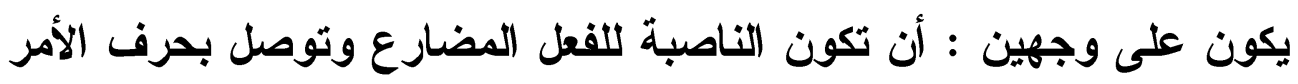

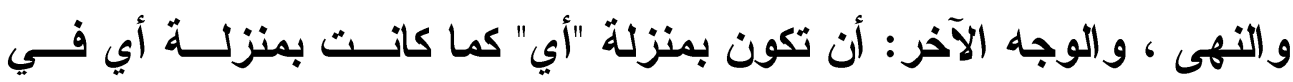

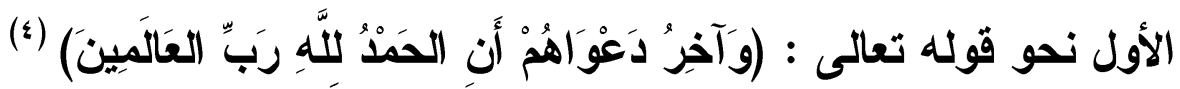
ولا تكون أنْ ناصبة للمضارع لأنَّه لا يبتدأ بعدها الأسماء ؛ لأنَّها تجئ

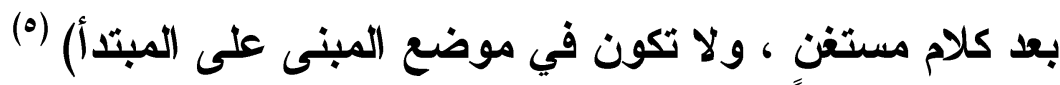
وعبر عنها ابن هثام بأنَّها هي المسبوقة بجملة فيها معنــى القــول دون

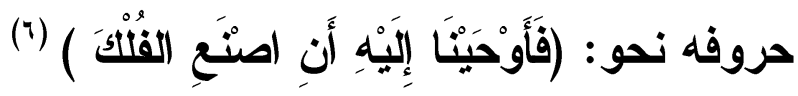

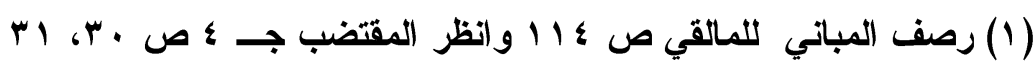

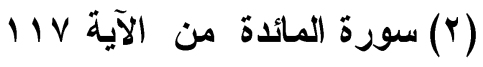

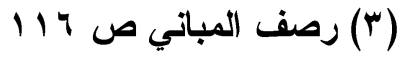

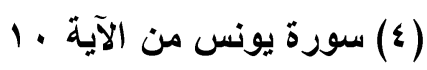

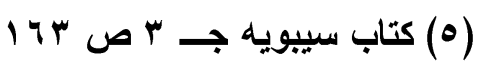

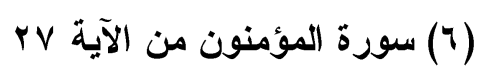




\section{الترقير الدولخ}

ISSN 2356-9050
Wio.

حولية كلية اللفة العربية بجرجا مجلة علمية محكمة العربة

النوع الرابع : "أن" الزائدة التي تقيد مجرد التوكيد وهي التي تقع بعد

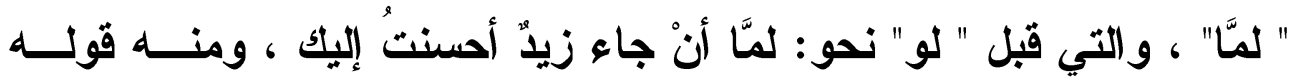

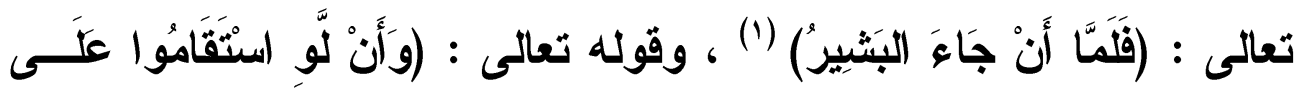

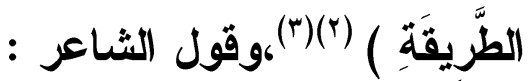

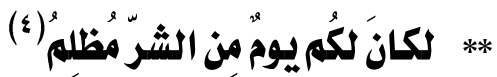

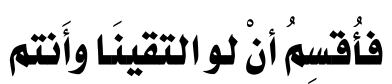

ومما سبق نجد أنَّه اتفق النحويون في أضرب "أنه" مفتوحة الهمزة خفيفـة النون فهي إمَّا مصدرية ناصبة ، و إمَّا مخفقة من الثقبلة ، و إمَّا تفسـيرية ،

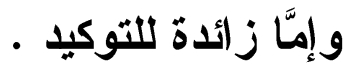

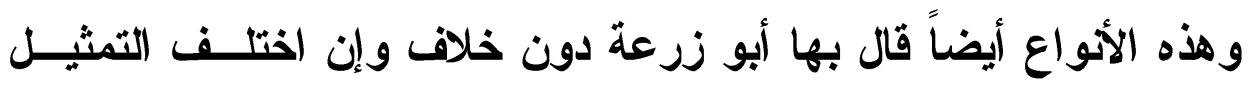

فقط.

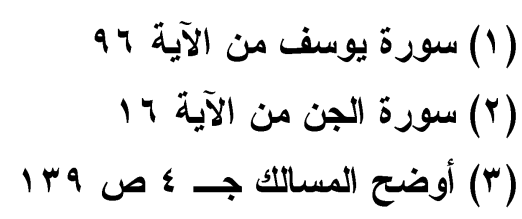

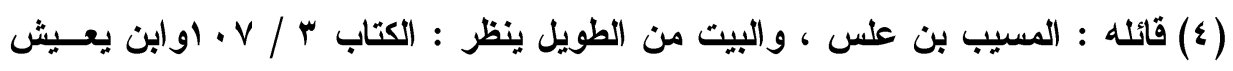

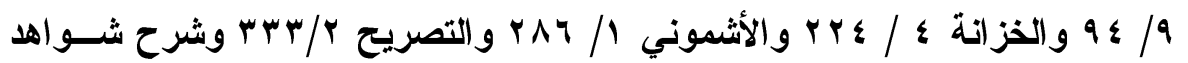
المغني ص • (المغ و 


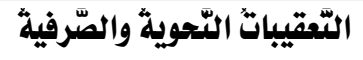

لأبي زرعة في كِتابه "حُجَّة القِراءَاتَ"

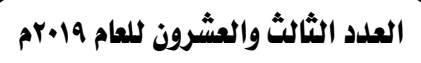

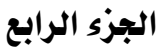

\section{r - إعراب الفعل بعد " حتى "}

قال الإمام أبو زرعة :( واعلم أنَّ (حتى) إذا دخلت على الفعـل فلهــا

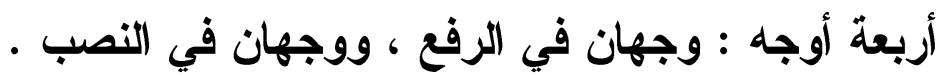

فأمَّا وجها الرفع فأحدهما : كقولك :( سرتُ حتى أدخلُها) فيكون السير واقعاً

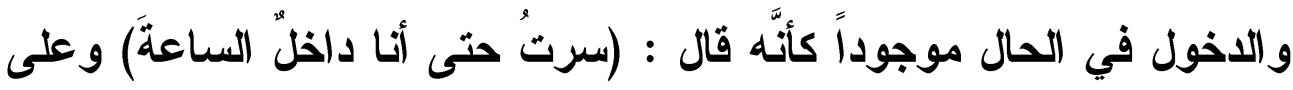

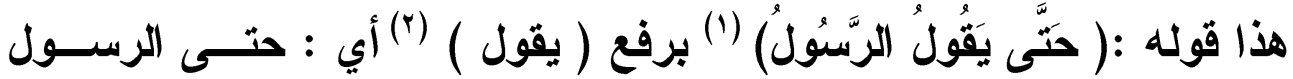
قائل . قل

و الوجه الثاني : أن يكون الفعل الذى قبل(حتى ) و الأى بعدها واقعـين

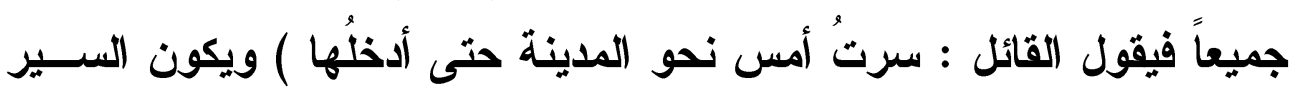

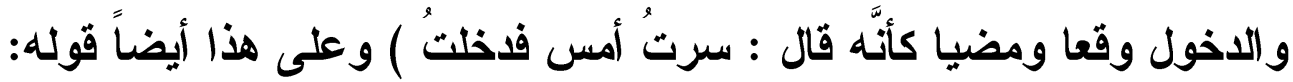

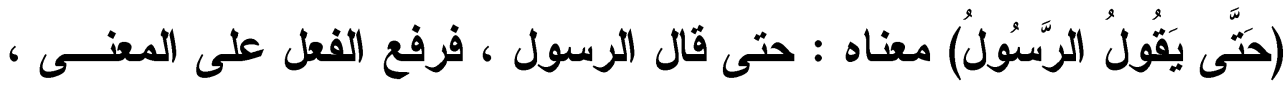

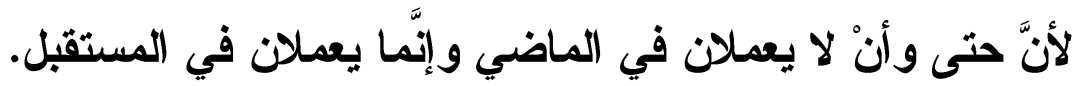

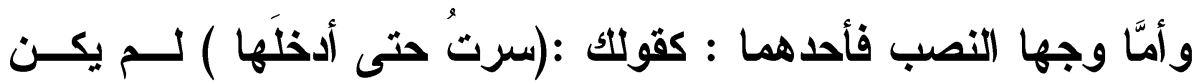

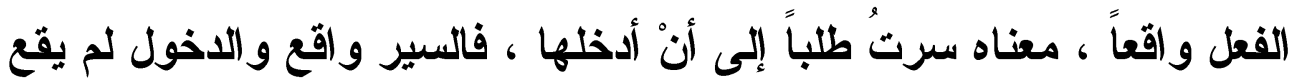

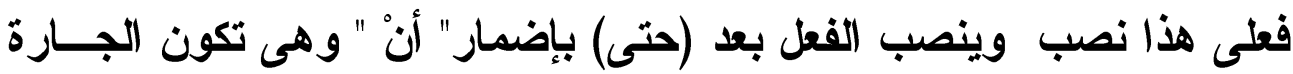

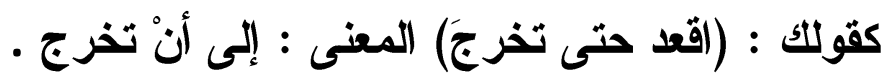

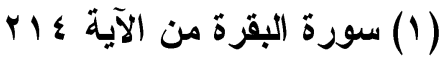

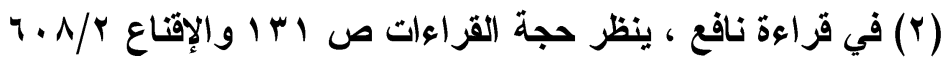




\section{الترقيم الدوله ISSN 2356-9050}

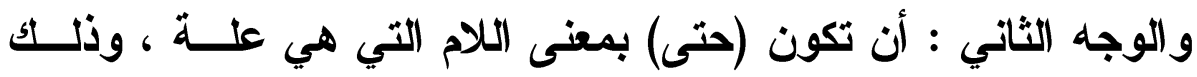

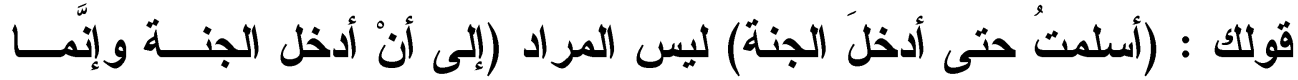

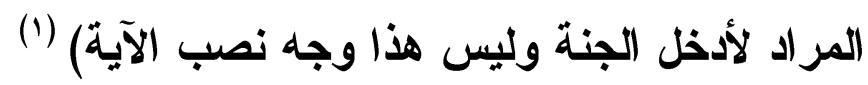
ما تضمنه كلام أبي زرعة :

لقد فصنَ الإمام أبو زرعة الحديث عن "حتى" الداخلة علــى الفــل ، الفـل

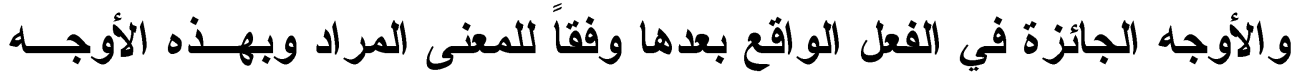

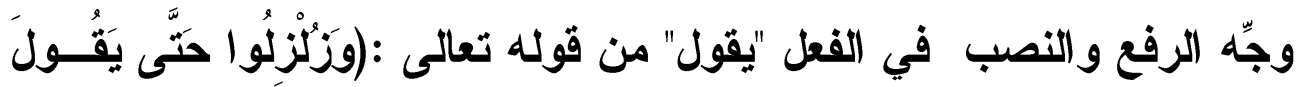

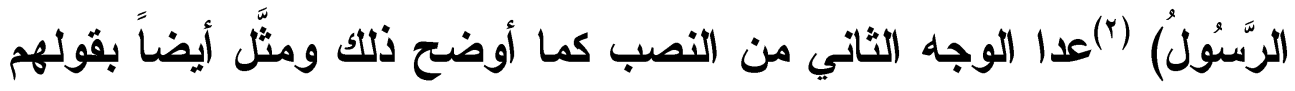
: - مرث حتى أدخلها .

الوجه الأول : الرفع على أنَّ الفعلين ( السابق عليها والواقع بعدها )

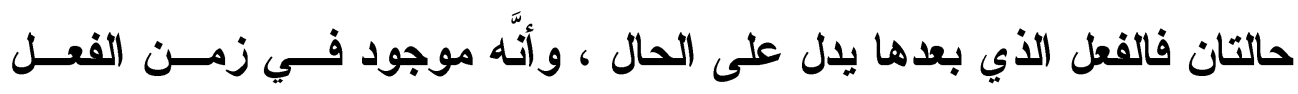

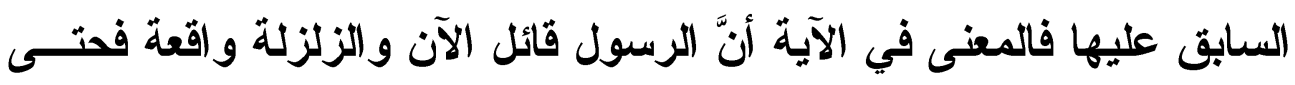

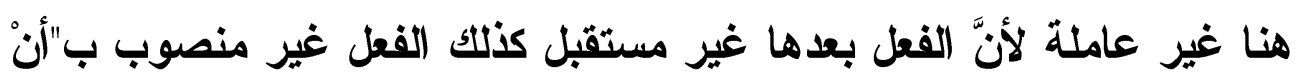

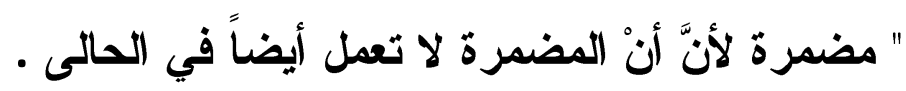

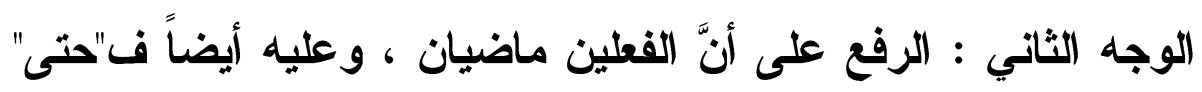
و"أن "غير عاملين في الفعل .

الوجه الثالث : النصب على إضمار " أن" بعد "حتى" فالفعل الذى قبلها و اقع ، أمَّا الذى بعدها فلم يقع فهو مستقبل ، وحتى هنا بمعنى إلى أنْ .

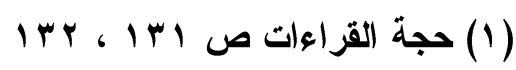

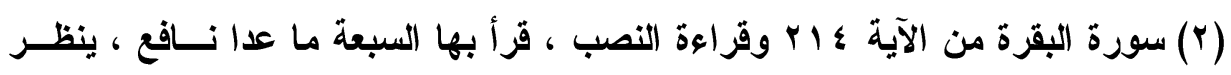

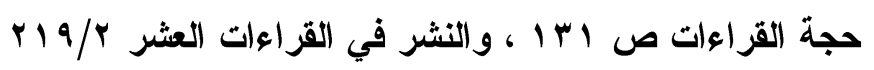


التعقيباتُ التّحوية والصّرفية

لأبي زرعة في كِتابِه "حُجَّة القِراكَاتَ" rior

rlor

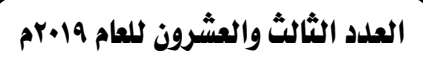

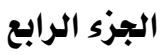

الوجه الرابع : النصب على أنَّ الفعل بعدها مســققبل وهــ تعليليــة

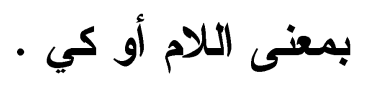

ومن خلا عرضه لهذه الأوجه الأربعة استطاع أبو زرعــة أن يبــزز

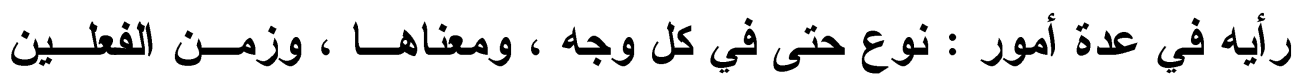

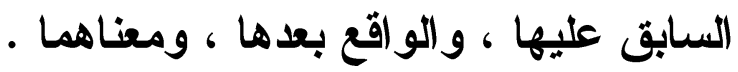

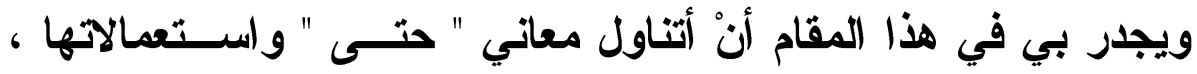
و الأوجه الجائزة في الفعل المضارع الو اقع بعدها ، وذلك من خلا مل مـا ورد في كتب النحو : أولاًا : همعانيدها . تأتى "حتى" لأحد ثلاثة معان :

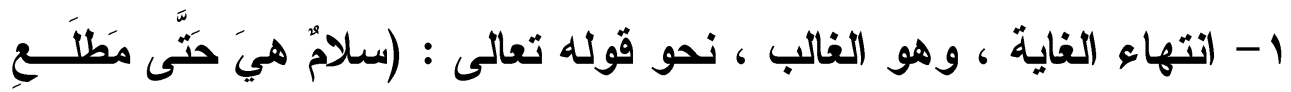

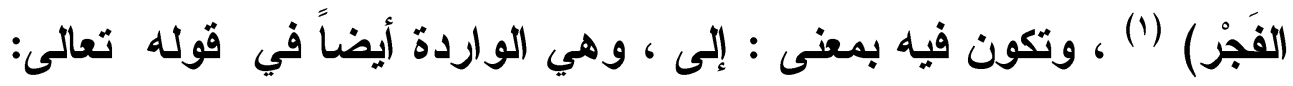

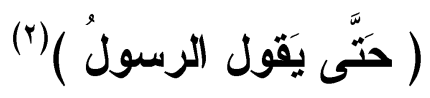

r) التعليل بمعنى : كي ، وقث قيل أيضاً إنَّها الواردة في الآية السابقة . (r) r - حتى التي بمغنى الفاء ، وهي السبيية ، وتكون حرف ابتــداء نحــو:

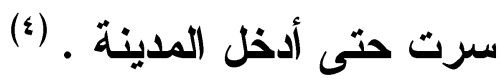
(1) (1) الآية ه من سورة القدر

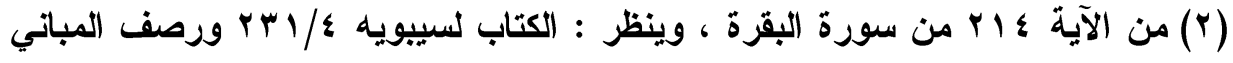

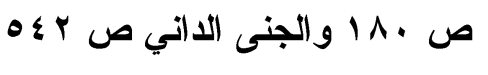

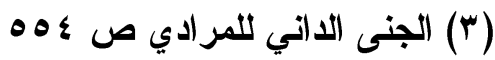

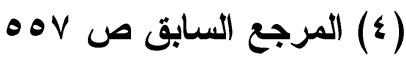




\section{الترقيه الدوله \\ ISSN 2356-9050}

W 104

حولية كلية اللفة العربية بجرجا مجية مجلة علمية محكمة

ع - بمعنى إلَّا في الاستثناء وهو أقنها. (1)

ثانيًاً : استعهمالاتهـا : تستعمل حتى على ثلاثة أوجه :

الأول : أن تكون عاطقة بمنزلة الواو ، نحو : قام القومُ حتى قام زيدٌ . الثاني : أن تكون حرف ابتداء ، نحو : قام القومُ حتى يخرج عمرو . الثالث : أن تكون حرفاً جارًا بمنزلة "إلى" في المعنى والعمل وتنفرد "حتـى "عن "إلىى" بأنَّها يجوز وقوع المضارع المنصوب بعدها نحو: ســرت حتــى

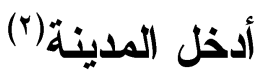

حكم الاخلة على الفعل المضارع : ذكر فيها النحويون مذهبين : المذهب الأول : وهو للبصريين أنَّ الفعل بعد "حتــى" منصــوب ب"أن" مضمرة؛ لأنَّ حتى تختص بالأسماء وما يعمل فى الأسماء لا يعمل فى الأفعال

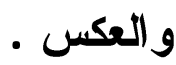

المذهب الثاني : للكوفيين أنَّ "حتى" تنصب المضارع بنفسها"َ). وذكر النحويون أنَّهَ لا ينتصب الفعل بعد حتى إلَّا إذا كان مستقبلاً ، فإن كان

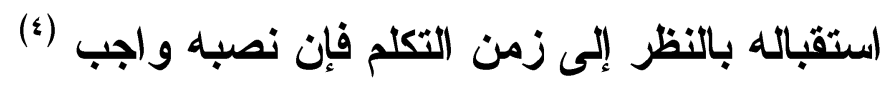

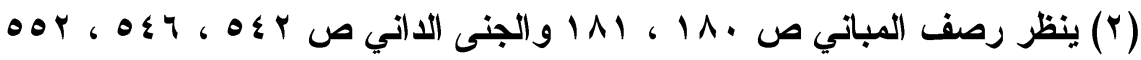

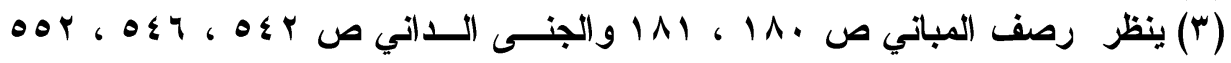

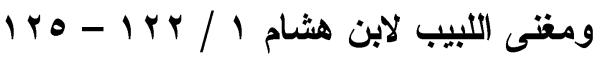

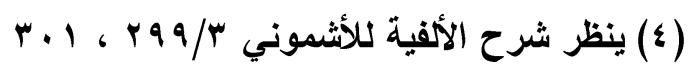


التعقيباتُ التّحويثة والصّرفية

لأبي زرعة في كِتابه "حُجَّة القِراءَاتِ"
(4) 1000
العدد الثالث والعشرون للعام 19. العزئ

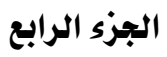

و إن كان بالنسبة إلى ما قبلها خاصة فالوجهان الرفع ، أو النصب نحو

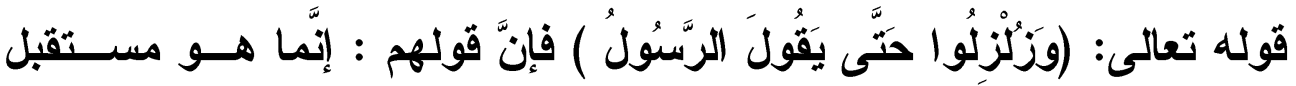

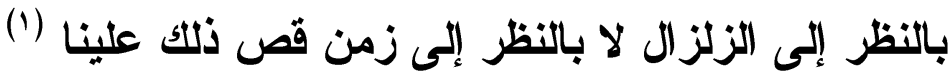
ويرتفع الفعل بعد "حتى" إذا كان حالاً ، وإن كانت حاليته بالنسبة إلـى إنى

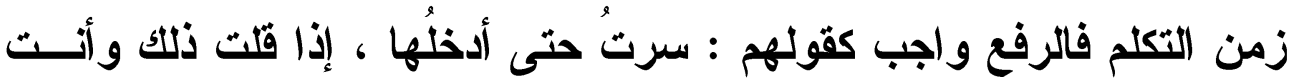

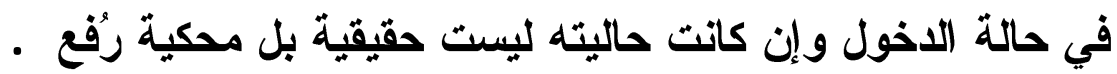

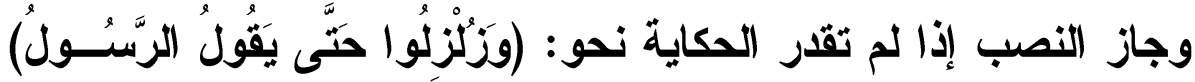

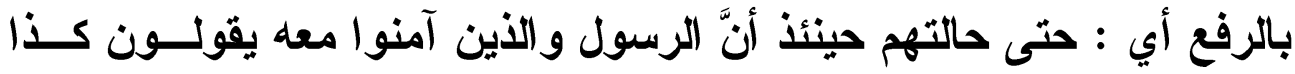
وكذا ولا بد لرفع الفعل بعدها من شروط : أولها : أن يكون حالاً ، أو مؤولاً بالحال .

ثانيها : أن يكون سبباً عما قبلها فلا يجوز: سرتُ حتى تطلع الثمس ، ولا ما سرت حتى أدخلها ، ولا هل سرت حتى تلدخلها.

والثالث : أن يكون فضلة فلا يصح في نحو: سيري حتى أدخلها. لئَّاّ يبقـى لئى

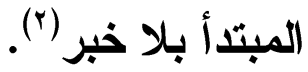

وهنا أعرض لبعض آراء النحويين مفصلة :

وأبدأها برأي سيبويه إمام النحاة ، ورأس المذهب البصري ، ولكن رغبــة في استجلاء رأيه في أمور هي :

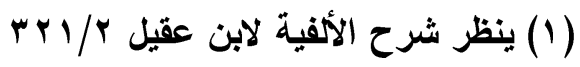

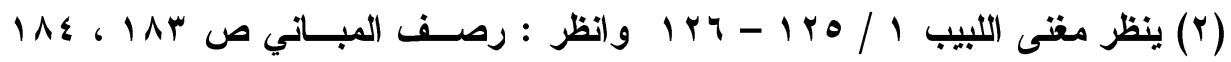

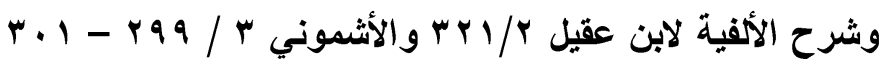




\section{الترقيم الدوله}

ISSN 2356-9050
(4) 104

حولية كلية اللفة العربية بجرجا مجلة علمية محكمة

1 - نوع ( حتى ) الاخلة على الفعل المضارع •

r

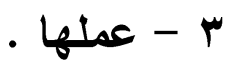

ع - معنى الفعل الواقع بعدها .

أمَّا عن نوع ( حتى ) في مثل : سرثُ حتى أدخلها ، وقوله تعسالى : ( حَّى يقول الرسول ) (') فهي ( حتى ) الجارة ، وهي التي لالتهاء الغاية ، و الفعل بعدها منصوب بأنْ مضمرة ، ولا يجوز إظهارها .

وحتى هنا غير عاملة قال سيبويه : ( واكتفوا عن إظهار (أن) بعدهما بعلــم المخاطب أنَّ هذين الحرفين لا يضافان إلى فعل ، وأنهّهما ليسا مما يعمل في

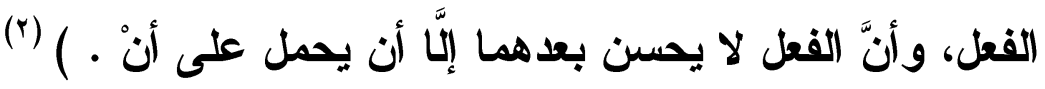

أمَّا إن جعلت السير قد حدث ومضى بالفعل فالفعل بعد حتى مرفــوع ، قال سييويه : ( وليس في الدنيا عربي يرفع : سرث حتى أدخلها ، إلَّا وهو

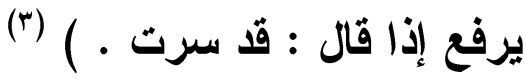

فالمعنى على الرفع : قد سرت حتى أدخله ، كما تقول : أرى زيداً سار حتى ياخلها ، برفع يدخلها .

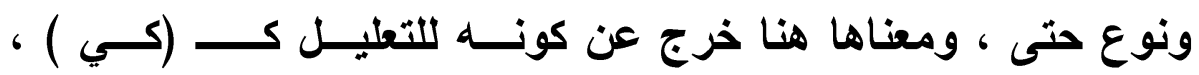

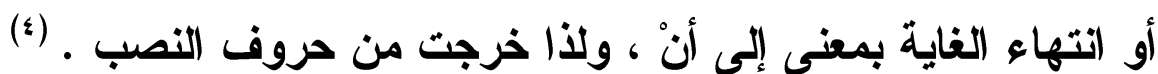

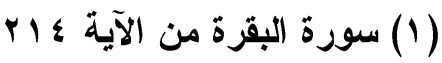

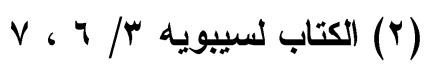

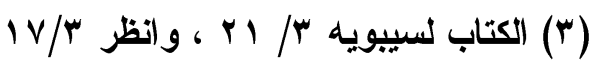

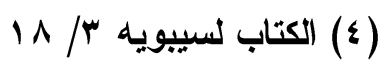




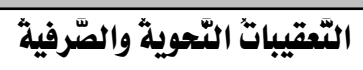

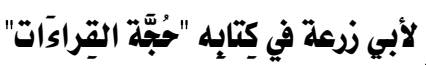

وقد أوجز سيبويه نصب الفعل بعدها في وجهين : الأول : أن يكون ما بعدها غاية لما قبلها .

الثاني : أن يكون ما قبلها ماضياً ، وما بعدها حالاً . (1) وأذكر منها أيضاً رأى المبرد الذى علل لنصب المضارع بعـــ "حتـى" بـ"أن" مضمرة لا بنفسها لأنَّ (أنْ) و الفعل تؤول بمصدر فهــي إذن داخلــة

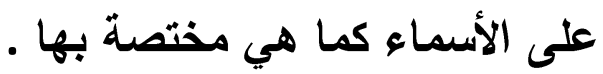

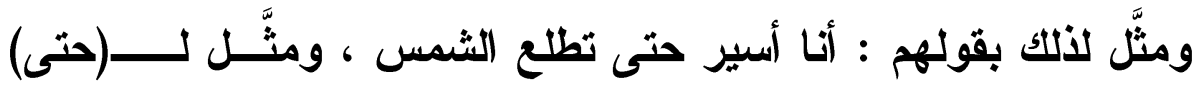
التي بمنزلة "كي" بقولهم : أطع الله حتى يدخلك الجنة. وفى كلا المثالين ألزم نصب المضارع . (r) أمَّا الرفع عند المبرد فقد جعله على وجهين ثم أرجع الوجهين إلـى وجه واحد في قولهم : سرث' حتى أدخلها ( وذلك قولـــ : ســرتُ حتـى أدخلَها. أي : كان منى سير فدخول فأتت تخبر أنَّك في حال دخول اتصل به فيه سيرك .

والوجه الآخر: أن يكون السبب متقدماً غير متصل بما تخبر عنه ثم يكـون مؤدياً إلى هذا كقوللك : مرض حتى لا يرجونه. أي : هو الآن كـــالك فهــو

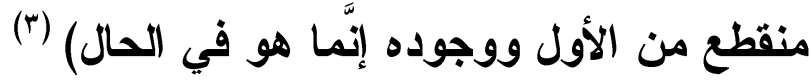
وعلل ابن الأباري امتناع النصب مع الماضي والحال فقال: (حتـى لا ينصب الفعل بعدها إلَّا إذا كان بمعنى الاستقبال، فأمَّا إذا كان بمعنى الماضي،

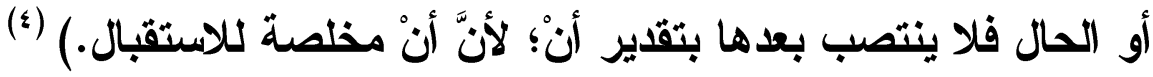

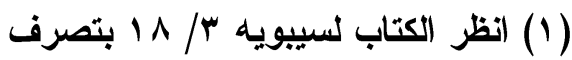

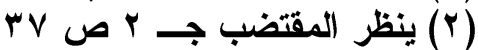

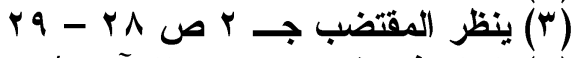

$$
\begin{aligned}
& \text { ( ) البيان في غريب إعراب القرآن / /. هـ }
\end{aligned}
$$




\section{الترقيم الدوله \\ ISSN 2356-9050}

فابن الأبباري يرى أنَّ إضمار أنْ يتنافى مع دلاكة الفعل على الحــال ،

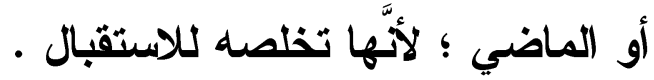

\section{ووجَّه العكبري الرفع بعد "حتى" بوجهين :}

الوجه الأول : أن يكون الفعل الأى قبلها والفعل الأى بعدها ماضيين فحتىى هنا تكون بمنزلة حرف العطف نحو: سرت حتى أدخلها. وقد وقع المضارع (أدخلها) موضع الماضي لحكاية الحال (') .

وبه قال أيضاً (بن يعيش(r) وابن هشام(r)

الوجه الثاني : للرفع عند العكبري أنَّ السير قد مضى والاخول حاضر (£) . وفي الآية يكون التقدير : وزلزلوا فقال الرسول ، فتكــون الزلزلـــة

سبب القول ، ويكون الفعلان ماضيان . (•)

أمَّا النصب عنده فعلى أنَّ حتى لاتثهاء الغاية ، والفعل بعدها مســتقبل حكيت به حالهم ، ولكن المعنى على المضي ، والتقدير عنده في الآية :إلى

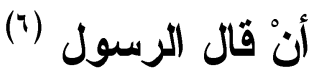

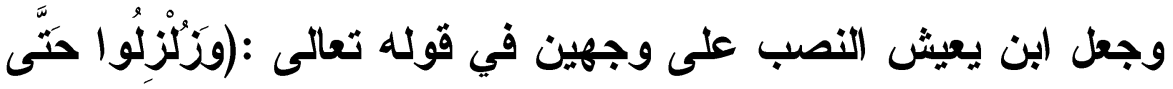

يَقْولَ الرَسَّنُولُ )

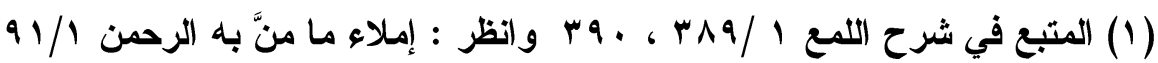

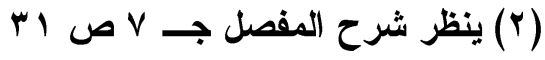

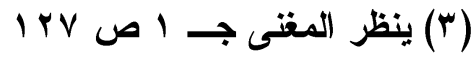

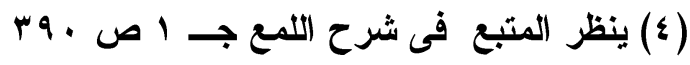

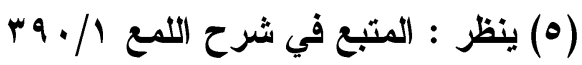

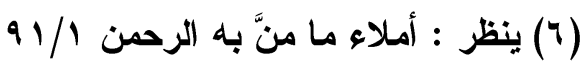


التّقيباتُ التّحوية والصّرفية

لأبي زرعة في كِتابِه "حُجَّة القِراكَاتَ"

الأول : أن يكون القول غاية للزلزال والمعنى : وزلزلوا فإذا الرسول

$$
\text { حتى حال قول. }
$$

والآخر : أن تكون حتى بمعنى "كي" فتكون الزلزلة علة للقول (كأنَّـهـه.

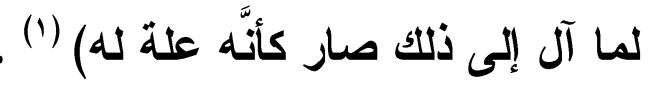

وجعل الرفع من وجهين :

الأول : أن يكون الزلزال اتصل بالقول ب"لا" مهملة بينهما ، لأنَّ القول

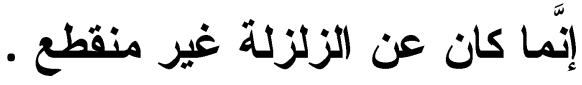

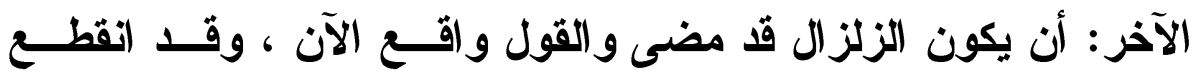

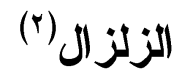

وبعد : فقد شظلت هذه القضية مساحات كبيرة في كتب النحو ، فما من

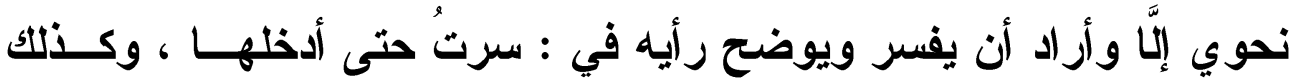

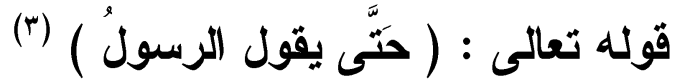

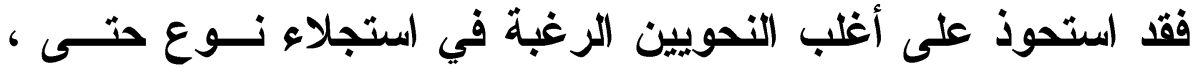

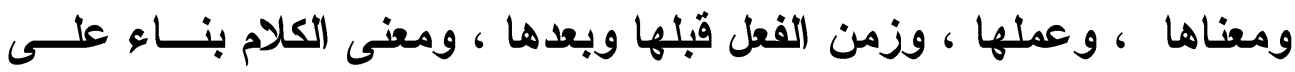
ذلك .

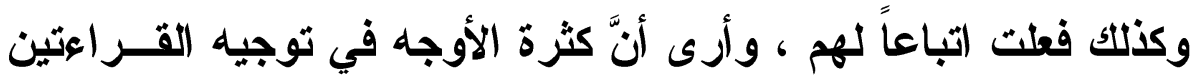

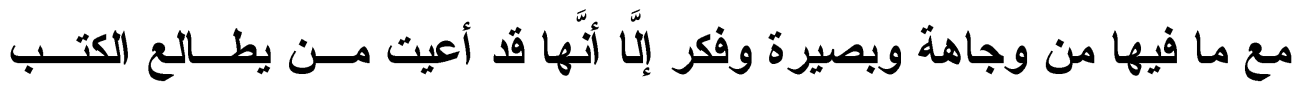

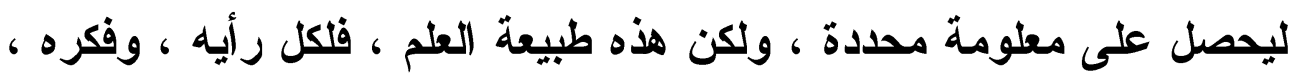

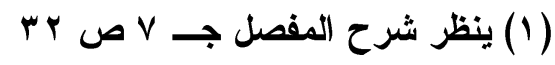

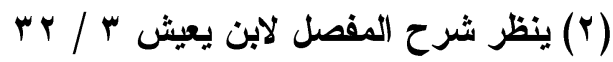

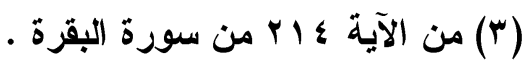




\section{الترقيم الدولم \\ ISSN 2356-9050}

وقت لاحظت أنَّ أبا زرعة ، وهو عالم بالقراعات قـ ذكر أيضاً أوجهاً متعددة

في هذه القضية .

وما اسنطعت استخلاصه أنَّ النصب في ( يقول ) بعد (حتى ) لا يتأتى

إلَّاّ والفعل مستقبل في المعنى .

أمَّا الرفع فعلى اعتبار الفعلين حاليين ، أو الأول ماضــي ، والثـاني

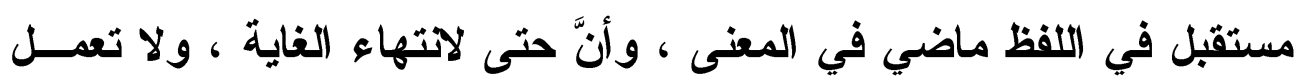

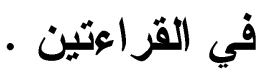


التعقيباتُ التّحويثة والصّرفية لأبي زرعة في كِتابه "حُجَّة القِراءَاتَ"
की 171

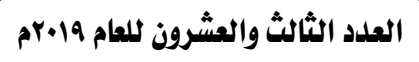

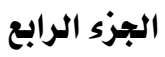

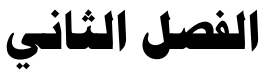

\section{تعقيبات أبي زرعة الصرفية \\ الإسناد إلى الضشمائر}

\section{حركة الفعل (هات) عند إسناده إلى ضهمائر الرفع المتحركة.}

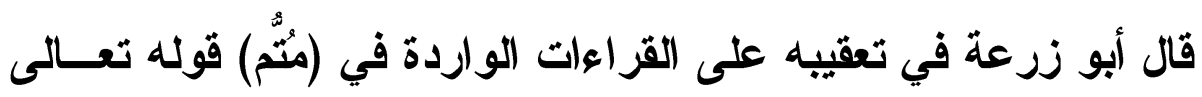

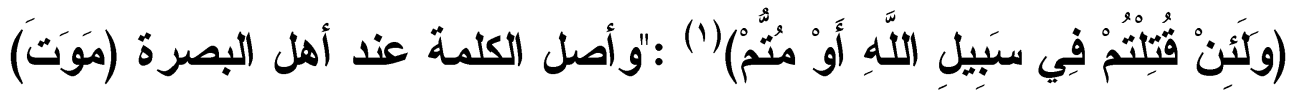

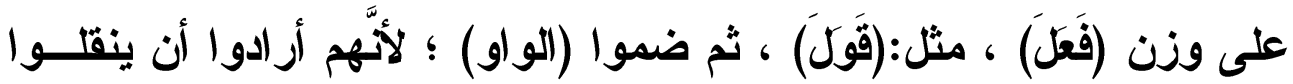

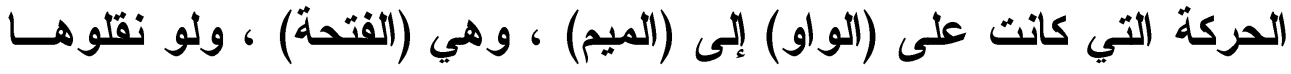

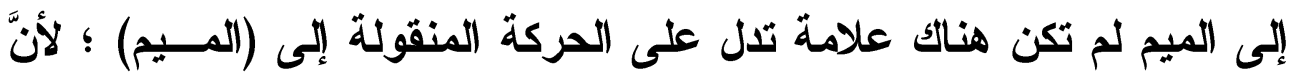

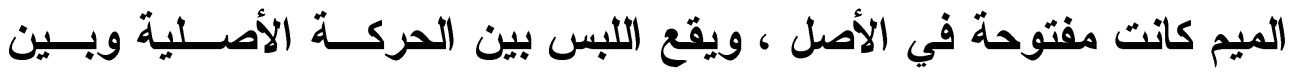

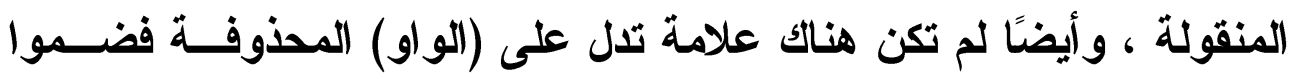

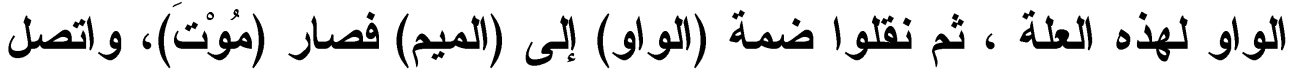

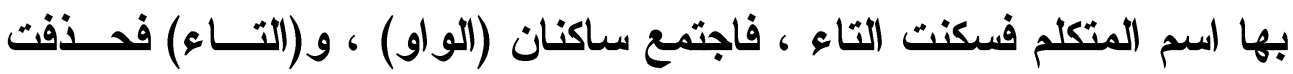

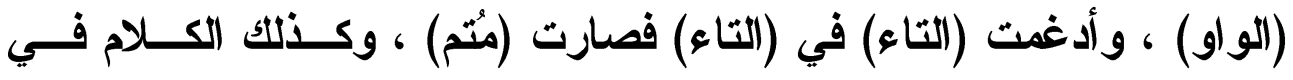

توجيه أبى زرعة لقر اعة (مُتّم) بضم الميم:

أولاً : عند توجيهه للقراعة أبرز بعض الأمور المتعلقة بالفعل مات من حيث

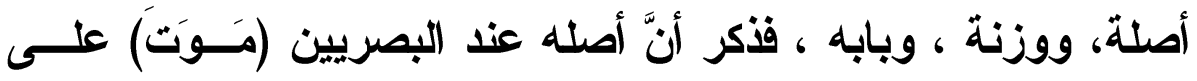

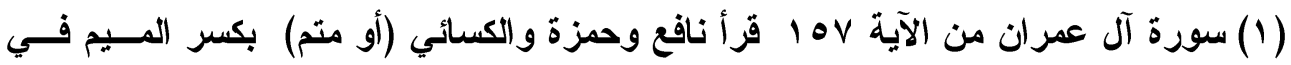

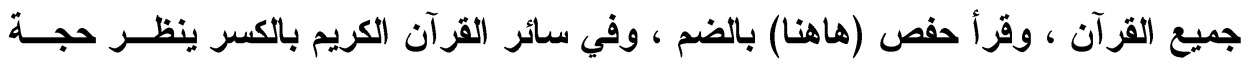

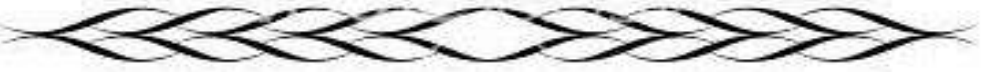




\section{الترقير الدولخ}

ISSN 2356-9050

وزن (فَعَلَ) بفتح العين وبابه (فَعَل يفعُل) بضم العين ، ونظيره وهــو معثل أجوف ، ونظيره من معتل التلام قال أصله : (قَولَ).

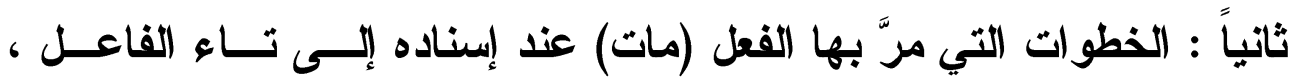
والتي أسماها تاء المتكلم ، وأرى أنَّ التعبير الأدق (تــاء الفاعـلـ) ؛ ليشمل تاء المتكلم وهي التاء المضمومة وتاء المخاطب ، وهي التــاء المفتوحة ، والتاء المخاطبة ، وهي التاء المكسورة.

$$
\text { وكاتت الخطوات كالتالي : }
$$

- 1 قلب فتحة (الواو) - عين الكلمة - إلى ضمة ، والعلة في ذلك أمران:

الأول : حتى يحدث اختلاف بينها وبين حركة (الميم) وهي (فاء الكلمة)، فإذا نقلت حركة (العين) إلى (الفاء) تميزت المنقولة عن الأصلية.

الثاني : لتكون الضمة المنقولة دليًا على الواو التي ستحذف بعد الإسناد. r - نقل ضمة (الواو) - عين الكلمة - إلى (الميم) - فاء الكلمـة - مــن (مَوَتُ) فصار القعل (مُوْتُ).

r- اتصل بالفعل (تاء الفاعل) ، فسكنت (التاء) مسـن (مسـوت) وهــي (لام) (الكلمة.

ع - اجتمع ساكنان (الو او) - عين الكلمة - و(التاء) - لام الكلمة - فذذت (الواو). ولم يذكر أبو زرعة علة إسكان (لام الفعل) عند الإسناد إلى (تاء الفاعل) وسيأتي علة ذلك في أثناء در اسة القضية . ه - جتمع تاءان التاء الأولي ساكنة ، والتاء الثانية تاء الفاعل المتحركة ،

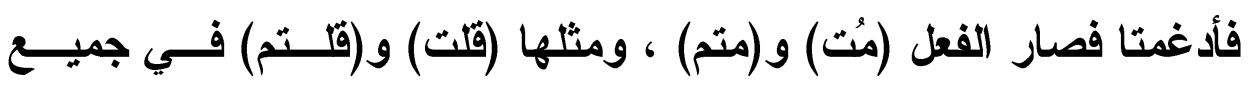




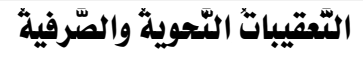

لأبي زرعة في كِتابه "حُجَّة القِراءَات" ritr

r $17 \%$

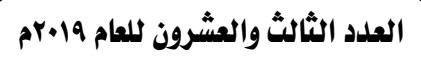
الجزء الرابع

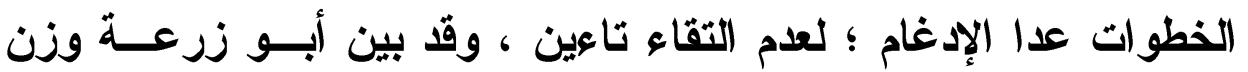

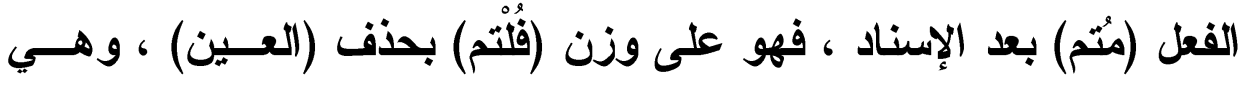
(الواو) ونسب ذللك الى البصريين.

أمَّا قر اعة كسر الميم في (متِّم) ، فإنَّ الفعل من باب (فعِل) - بكسـر العين - (يفعُل) بضم العين ، وعند الإسناد مر بالخطوات الآتية :

1- استثقتلت الكسرة على (الواو) فنقلت إلى (الميم) ، وســكنت (الـــواو) ، فصار الفعل (موتْ) .

r- اتصل بالفعل (تاء الفاعل) ، فسكنت (لام الفعل) ، وهي (التاء). r- اجتمع ساكنان (الواو) و(التاء) بسبب الإسناد ، فحذقت (الواو).

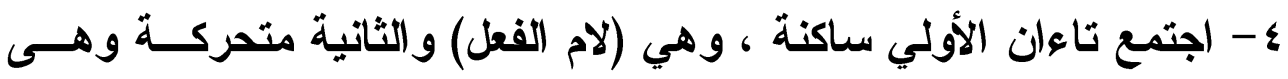

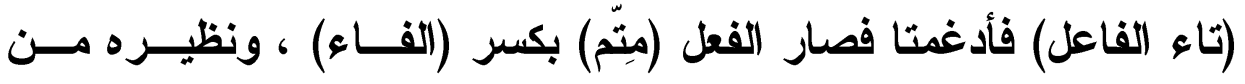

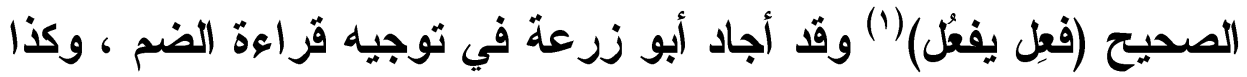

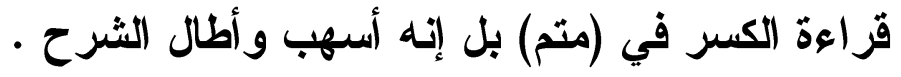

\section{الدراسة والتحليل :}

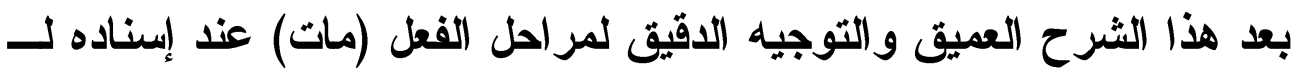

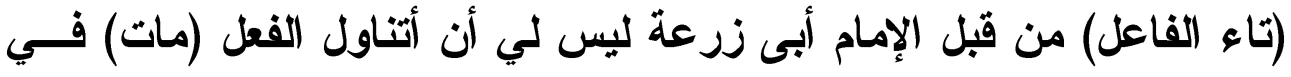

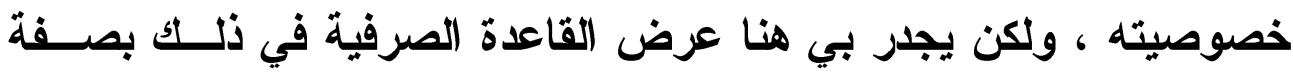
عامة من خلال ما قيل في كتب الصرف و النحو لأضع كلامسـه فــي ميـزان التقييم.

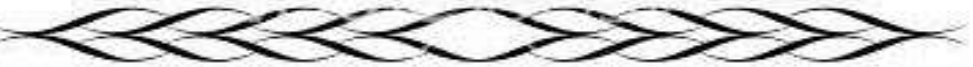


الترقير الدولم ISSN 2356-9050

فالقاعدة تقول : إنَّ الفعل الثُلاثي الأجوف إمَّا أن يكون مفتوح العـين

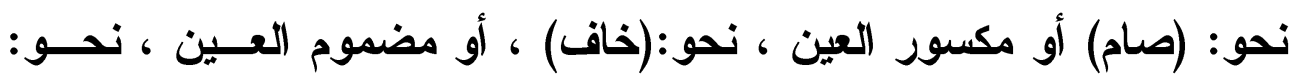

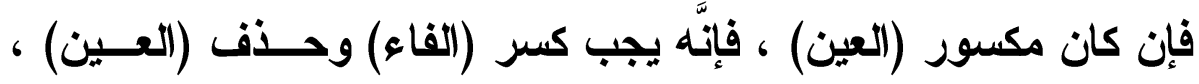

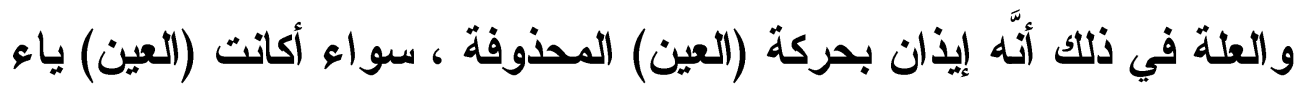

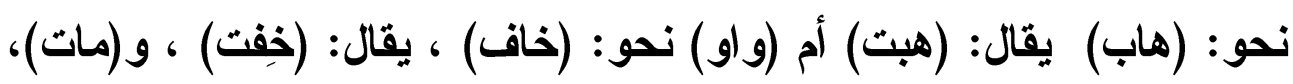

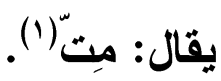

وإن كان الأجوف الثثلاثي مفتوح (العين) فإنَّهُ يفرق بين واوي (العين) وياعيه.

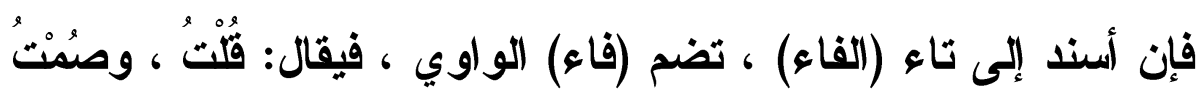

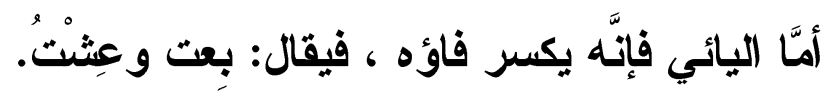

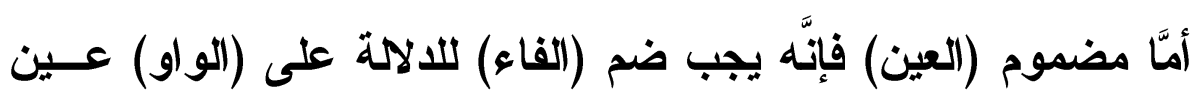

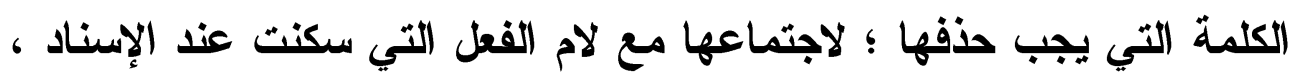
فيقال: طُنْتُ.

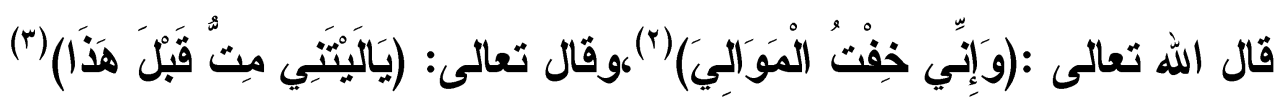
الفعل (مات) وأي الحالات تنطبق عليه :

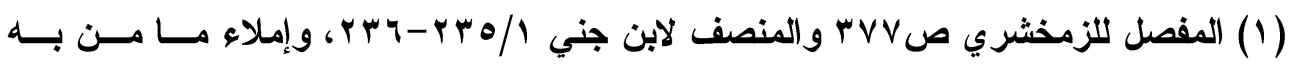

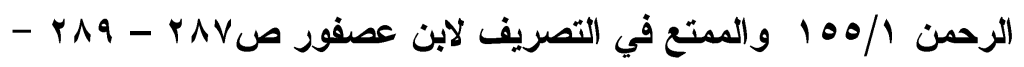

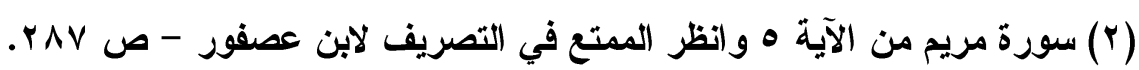

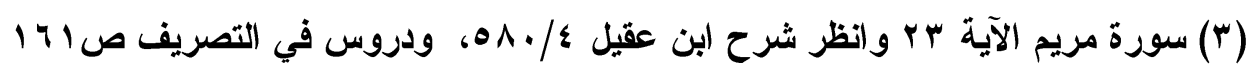




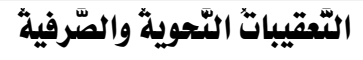

لأبي زرعة في كِتابه "حُجَّة القِراءَات"
P170

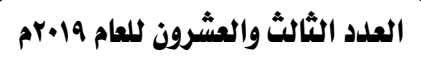

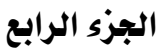

ذكر سييويه أنَّ الفعل مات من باب (فعِل يفعُل) بكسر العين فـــي الماضــي

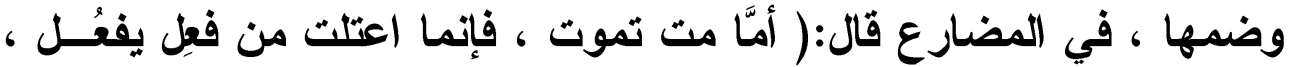

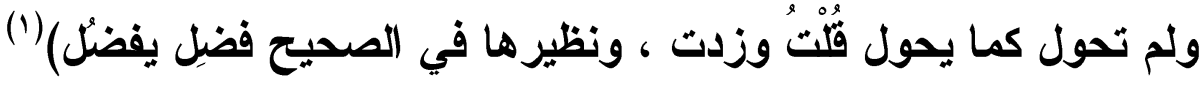
فذكر ممائلاً لها من الصحيح (فضليل يفضُل) ، وهو ما ذكره أبو زرعة. اللغات الواردة في ماضي الفعل (موت) ومضــارعه وآراء النحسـويين فـي

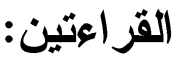

ورد في ماضي هذا الفعل ومضارعه لغات :

أولها : مات يمات ، كما يقال : خاف يخاف ، وحكم سييويه بثذوذه(†) بينما حكم عليه العكبري بأنَّه لغة واردة عن العرب مثلها مثل خاف يخاف ،

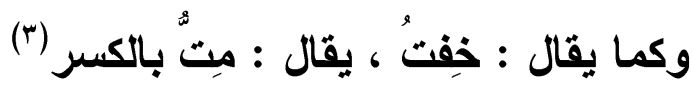

أمَّا أبو حيان فقد ذكر أنَّ (مُت) بالضم أقيس وأثنهر ، والكسر مستعمل

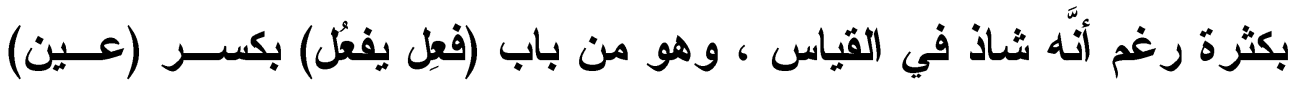

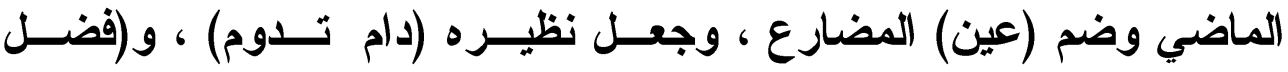

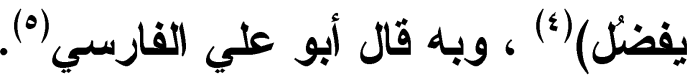
وعليه فالفعل مات في بابه لغتان :

$$
\begin{aligned}
& \text { r }
\end{aligned}
$$

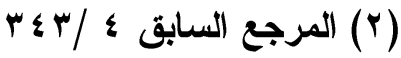

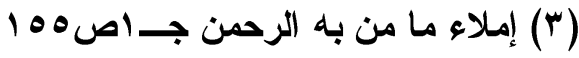

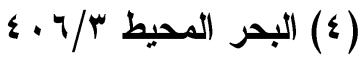

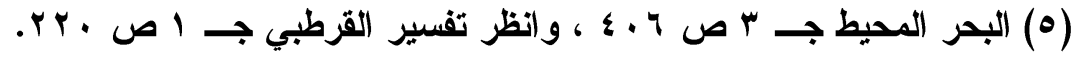




\section{الترقيم الدوله \\ ISSN 2356-9050}

الأولى : أنَّهَه من (فَعل يفعُل) بفتح (عين) الماضي وضمها في المضـــارع ،

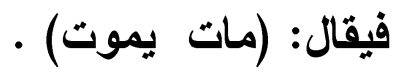

والأخرى : فعل يفعل بفتح العين فيهما فيقال : (مات يمات ، وبهذا لا تكون شاذة ، فهي لغة واردة مسموعة ، ونسبها أبو حيان إلى الحجـازيين وجعل منها قول الشاعر:

عيشي ولا تومي بـأن تقاتي (1)

ونسبها ابن منظور إلى الطائيين . (r)

أمَّا الأبباري فقد سهل القضية وأوجز التوجيه ، فنكر أنَّ من قرأ (مِتم) بالكسر، فالفعل من باب (فَعِل) بكسر العين ، ونقلت كسرة (العين) إلى الفاء. ومن قرء (مُتم) بالضم ، فالفعل من (فعل) بفتح العين ، فقلبت القتحة

ضمة، ونقلت إلى الفاء(").

ولا أود الإطالة في هذه القضية ، فما ذكر قد يغتي القارئ - إن شـــاء الله - بإحاطته بجوانب قضية إسناد الفعل الثلاثي الأجوف إلى ضمير الفاعل بصفة عامة ويجد في توجيه النحويين للقراعتين بوجه خاص ما يقتع سواء كان ذلك من خلال توجيه أبي زرعة أو غيره من النحويين والمفسرين.

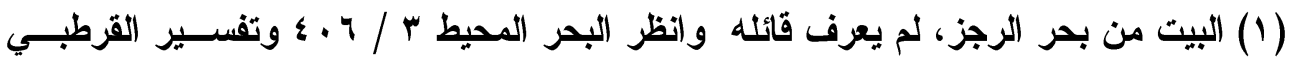

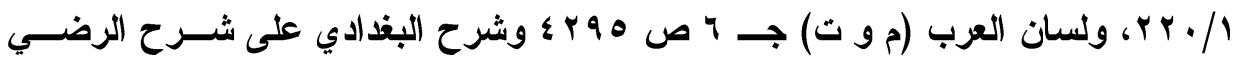

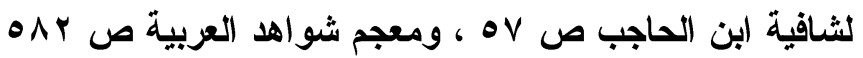

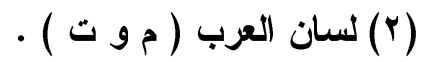

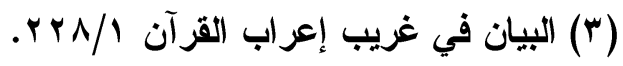




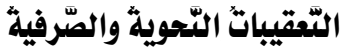
لأبي زرعة في كِتابه "حُجَّة القِراكَاتِ"
Q.
العدد الثالث والعشروز للعام 19 العزي

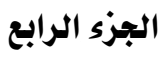

\section{باب الاشتقاق}

\section{ا - اسم الذَّت ، واسم المَرَّة}

قال الإمام أبو زرعة : (اعلم أنَّ الغَرفة) المصدر تقــول : (اغترفــــ

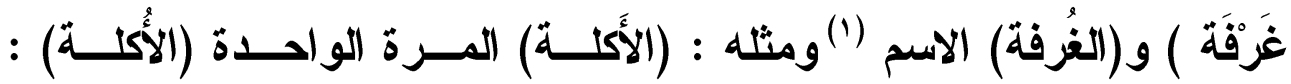

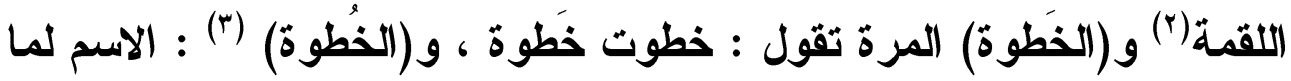

بين الرجلين()

ما تضمنه كلامه من أفكار : - ما

يشير الإمام أبو زرعة هنا إلى الآتي :

1 - أنَّ ما كان على وزن ( فَعلة ) بفتح الفاء مختوماً بالتاء يكون مصـــراً

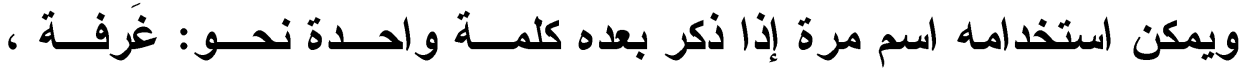

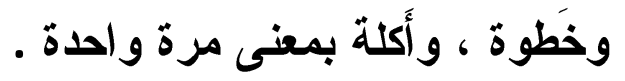

r - أنَّ ما كان على وزن ( فُعلة ) بضم الفاء مختوماً بالتاء فهو اسم ذات

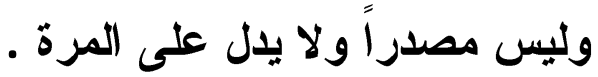

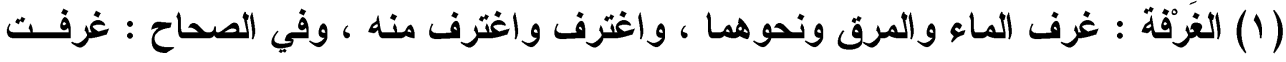

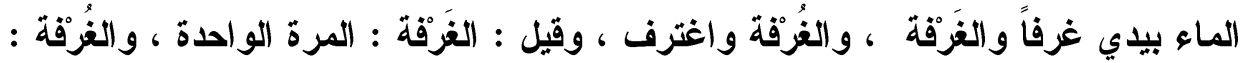

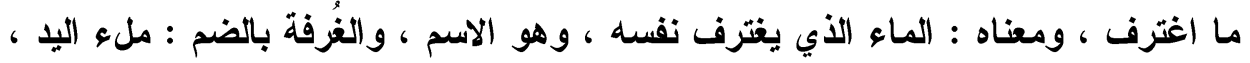

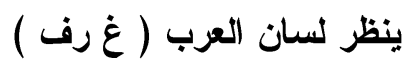

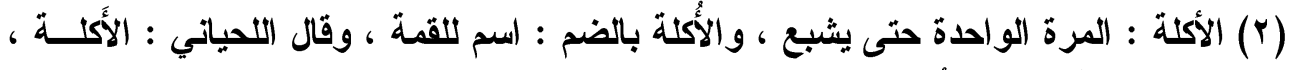

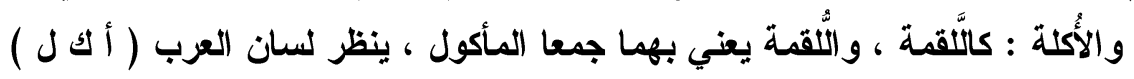

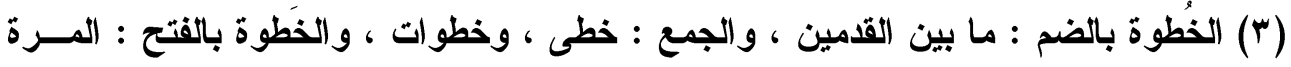

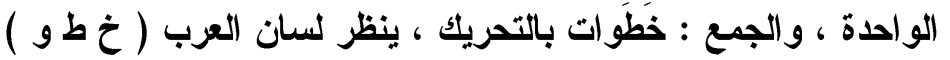

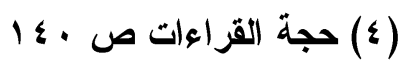


الترقير الدولا

ISSN 2356-9050

r - جاء كلامه في معرض توجيه قراعة قولهه تعالى : (1) إلَّا مَن اغَتَرَتَ

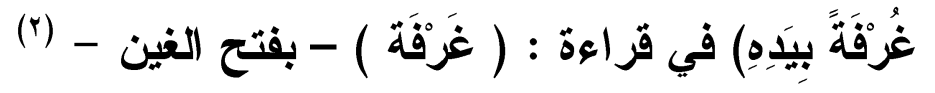

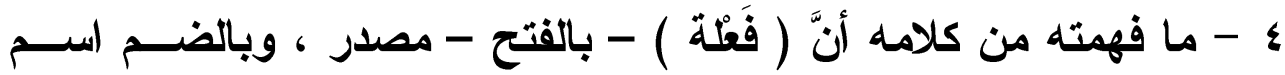

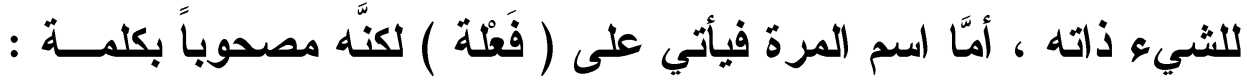

$$
\text { واحدة . }
$$

ه - ورد في كلامه ثُلاثة أمثلة فرَّق فيها بين : اسم المرة ، واسم الـــات ،

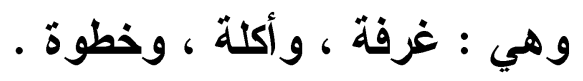

ومقتضى الكلام في هذه القضية أن أعرض الآتي :

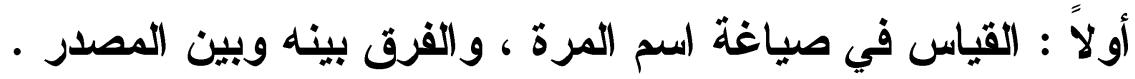

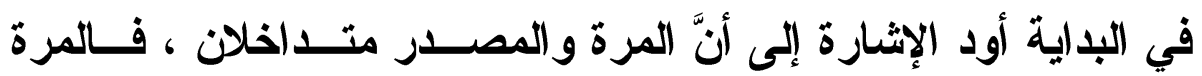

مصدر على وزن ( فَعلة ) بفتح فسكون نحو: جلس جلَسنة ، وأكل أَكلَة .

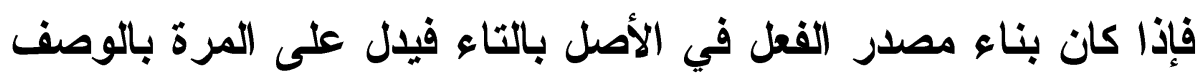

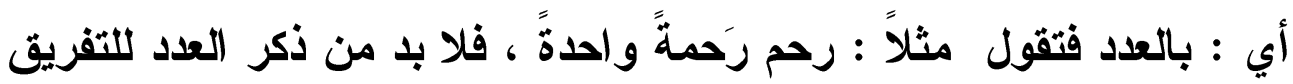

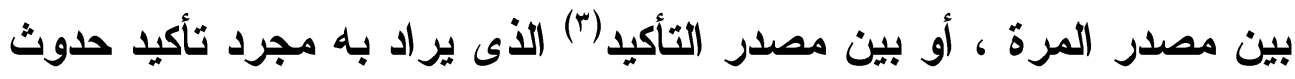

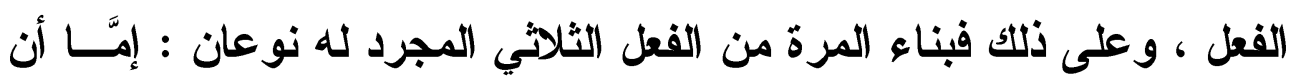

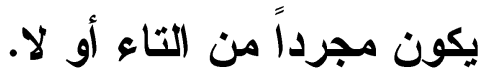

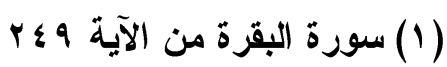

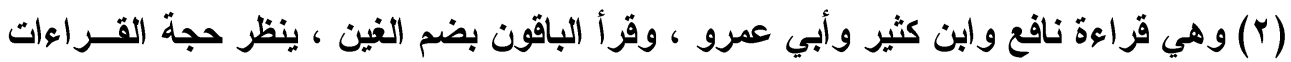

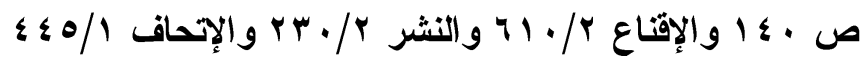

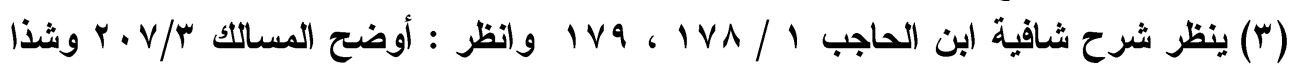

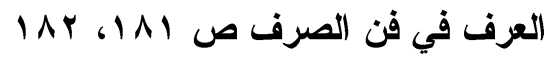




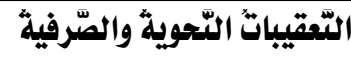

لأبي زرعة في كِتابه "حُجَّة القِراءَاتَ"
P179

PI 79

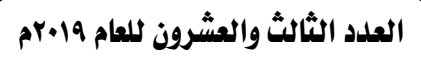

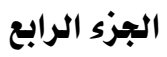

فإن كان مجرداً من التاء جاء اسم المرة على وزن ( فَعلة ) بفتح الفاء

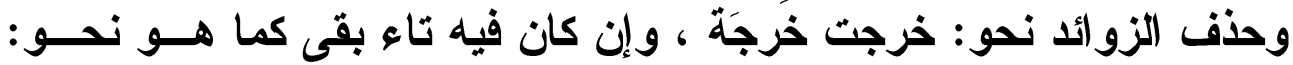

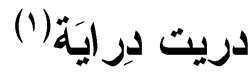

ومما هو جدير بالاتتباه إليه هو أنَّ اسم المرة لا يشتق من كل مصدر،

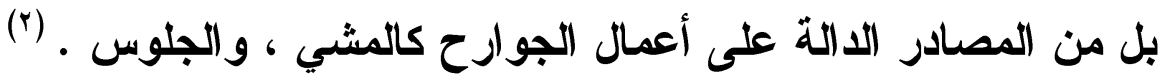
هذه هي القاعدة الصرفية في كيفية صياغة اسم المـــرة ، والقيـاس فيها، وكيف يفرق بينها وبين المصدر إذا اتقق وزنهما . ثانياً: : رأي النحويين في هذه القضية :

تعرض كثير من النحويين إلى كيفية الفصل بين اسم المرة ، والمصدر

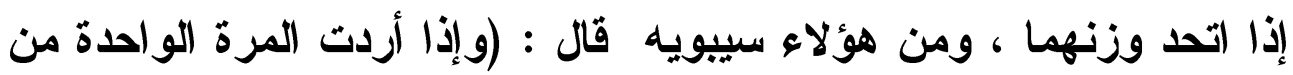

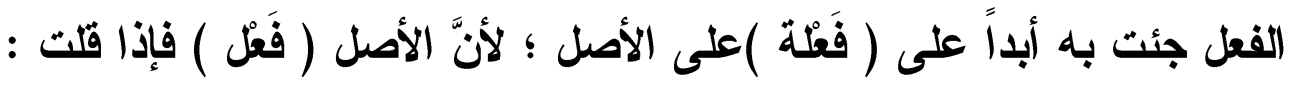

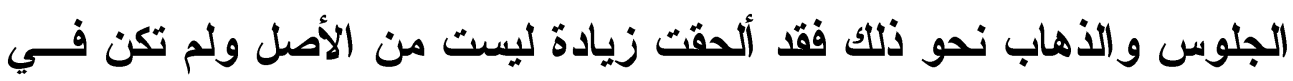
الفعل وليس هذا الضرب من المصادر لازماً بزيادته لباب فَعل كلزوم الإفعال

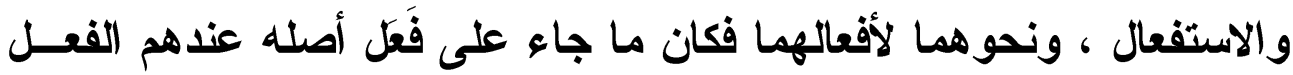

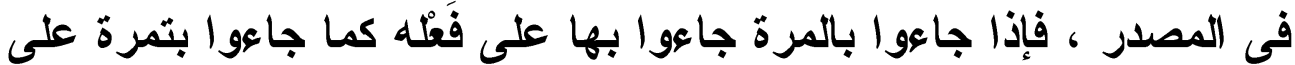

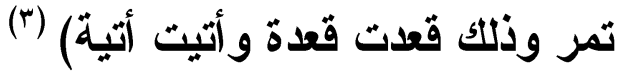

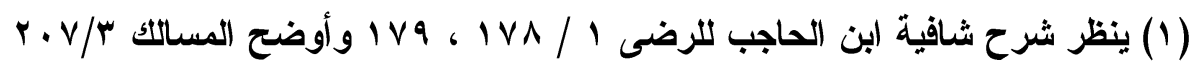

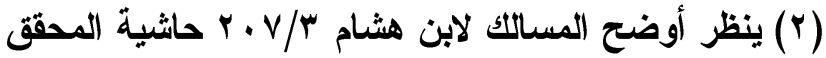

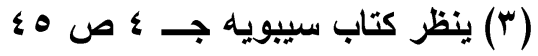




\section{الترقير الدولخ \\ ISSN 2356-9050}

فالأي فهم من كلام سيبويه أنَّ المرة من الثلاثي سواء بالتاء ، أو من غيرها يرد إلى فَعلة بالفتح ؛ لأنَّ أصل جميع مصادر الأفعال الثذلاثية المجردة

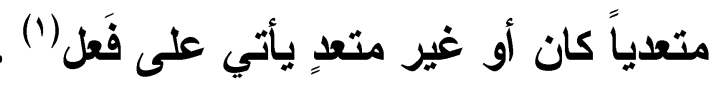
والأى ير اه الرضي(r) أنَّ المصدر يأتي على فَعلة بالقتح ، وهذا لــيس

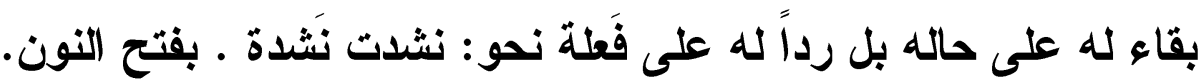
أمَّا اسم المرة من مزيد الثتلاثي فيأتي بزيـــادة التــاء علـــى مصــــره كانطلاقة ، وإذا كانت التاء في مصدره دل عليها بالوصف كإقامة طويلة)(ب) إذن غير الثلاثي يأتي بإضافة التاء في آخر المصدر بالقياس(\&) وعليه فالقاعدة الصرفية تقول : إذا أريد بيان المرة من مصدر الفعل الثناثي

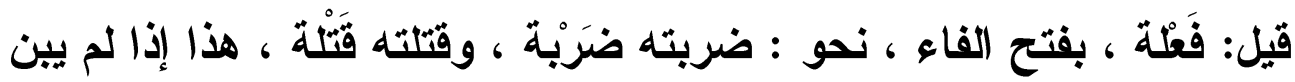
المصدر على تاء التأنيث ، فإن بني عليها وصف بما يدل على الوحدة ، نحو

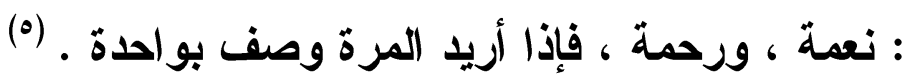
ثالثًاً : توجيه قر اعة غَرْقة بالقتح ، وغُرْقة بالضم : أمَّا ابن الأبباري والعكبري فقد ذكرا في الفرق بين : الغرْفة - بالضم - ، والغَرفة - بالقتح - وجهين :

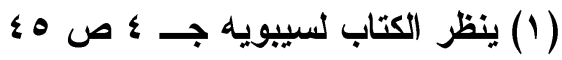

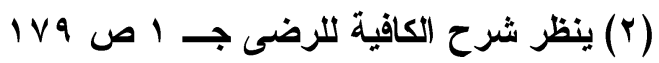

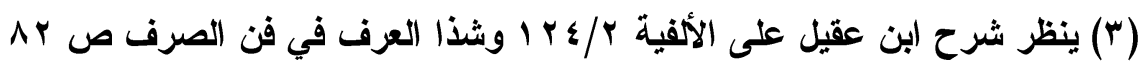

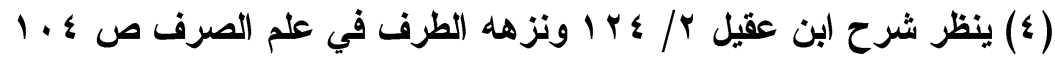

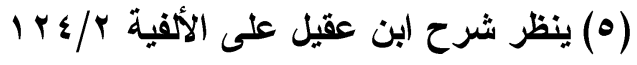

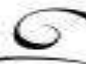


التّقيباتُ التّحوية والصّرفية لأبي زرعة في كِتابِه "حُجَّة القِراكَاتِ" mivi

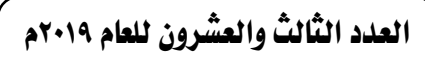

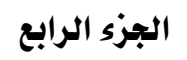

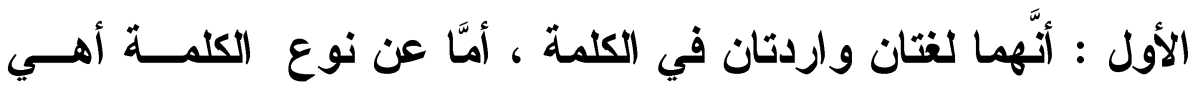

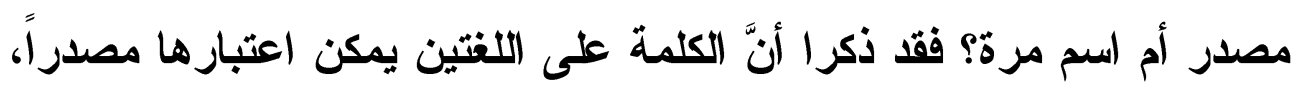

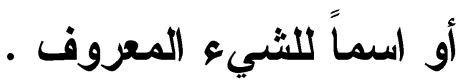

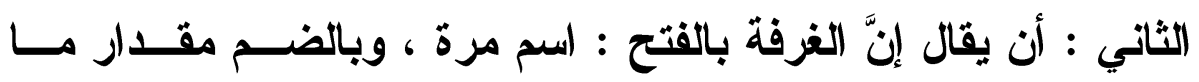

تحمله اليل (1)

وعلى الوجه الثاني لا يظهر فرق في الدلالة بين ما يفيده اسم المــرة

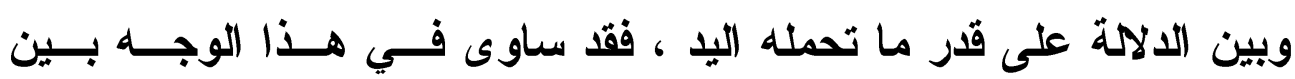

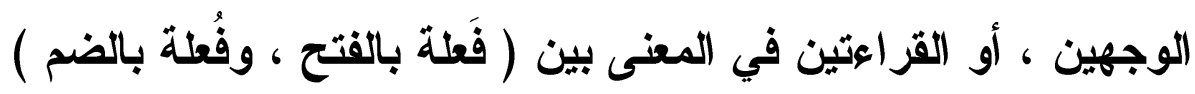

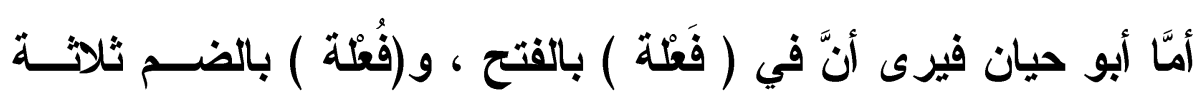

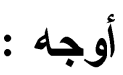

الوجه الأول : أنَّهما بمعنى واحد ، وهما مصدران ، فيكون مصدرهما غير قياسي، و المفعول محذوف الاول : لهون

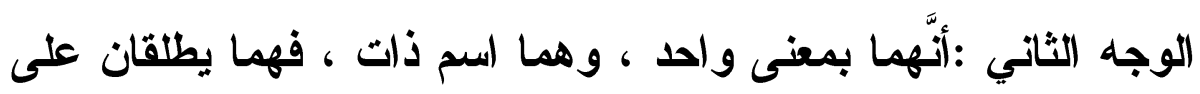
المعروف ، فيكون إعرابه عنده مفعولاً به .

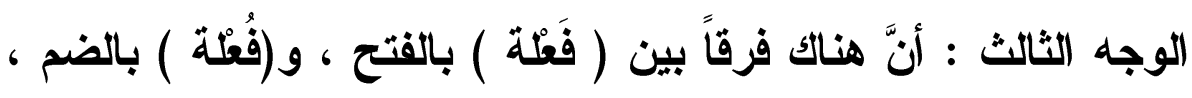

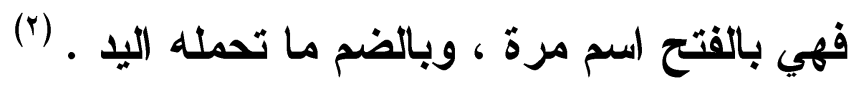

وفي الوجه الثالث يتطابق رأيه مع ما ذكره ابن الأباري والعكبري .

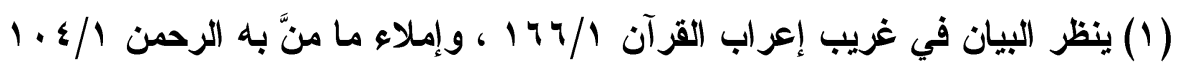

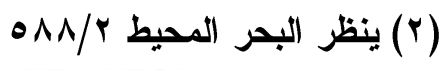




\section{الترقيم الدوله \\ ISSN 2356-9050}

وقد أنكر أن يكون مصدراً ؛ لأنَّ مصدر الفعل اغتــرف : اغتر افـــة ،

وحكى ابن عطية عن الفارسي أنَّه رجَّح ضم الغين ، وكذلك الطبري . (1)

هذا ولم يشر أحد إلى أنَّ لفظ : غُرْفة بالضم بمعنى : حجرة ، ولعـلـ

ذلك لأنَّ المعنى ودلالة الحال تفصل بين المعنيين .

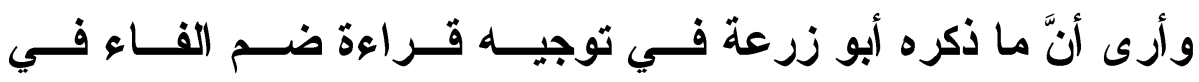

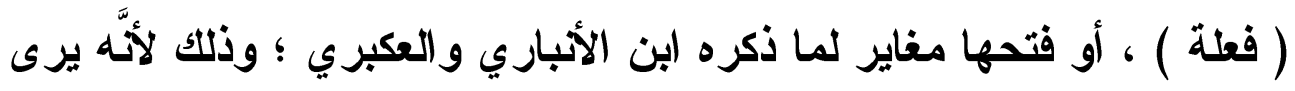

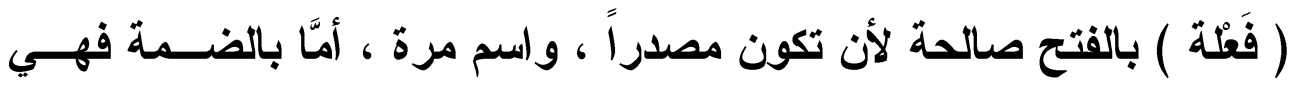
اسم للشيء المعروف . 

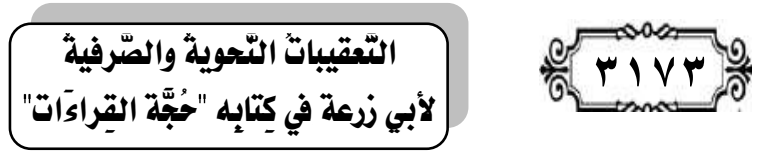

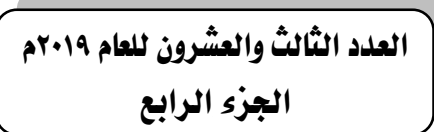

\section{r - نيابة اسم المكان عن المصدر}

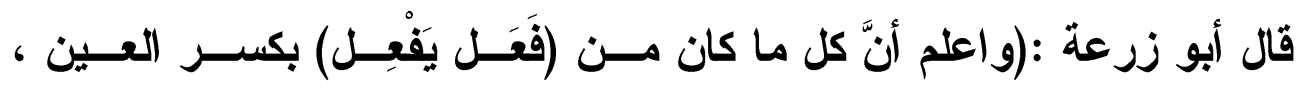

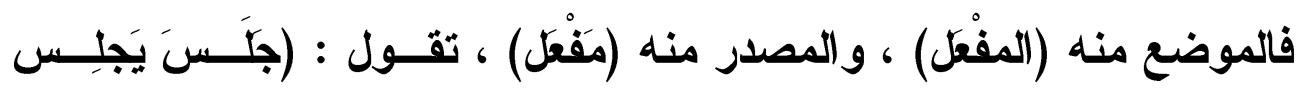

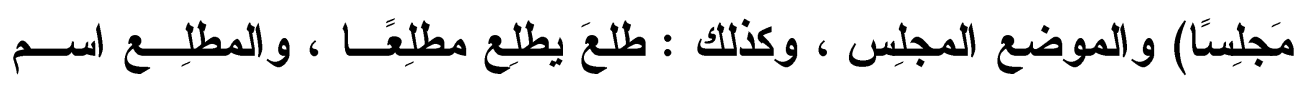

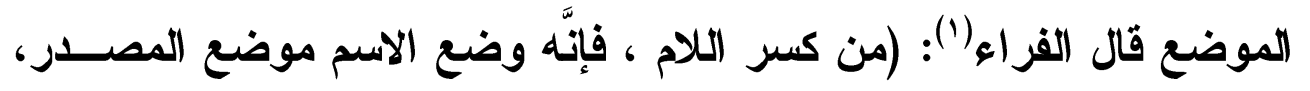

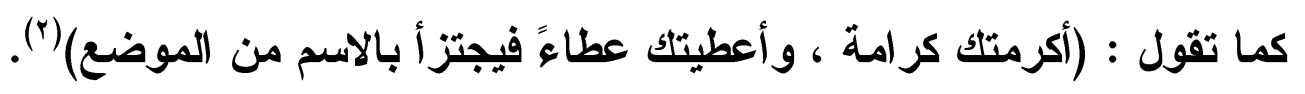
ما تناوله أبو زرعة من قضايا صرفية :

1- تناول أبو زرعة في مجمل كلامه القاعدة الصرفية فــي صـياغة اســـ

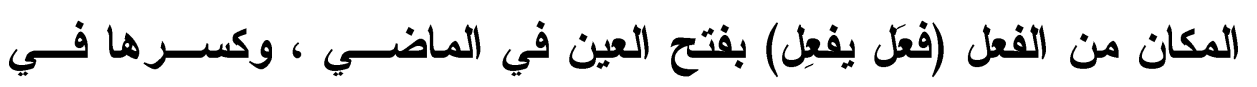

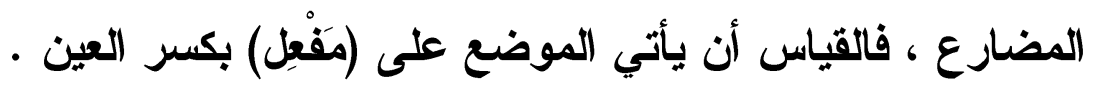
r- تناول أبو زرعة القياس في صياغة المصدر، ولعلــه يقصــــ المصــدر

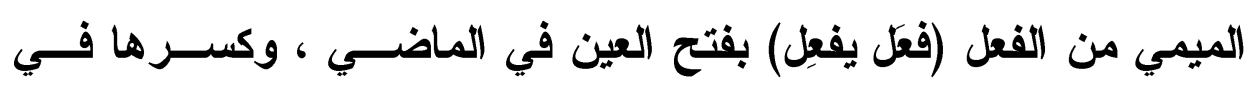

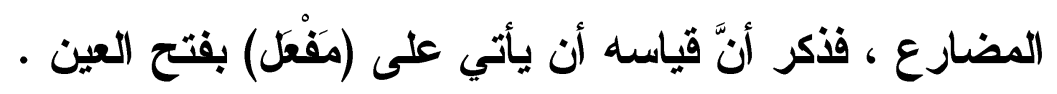

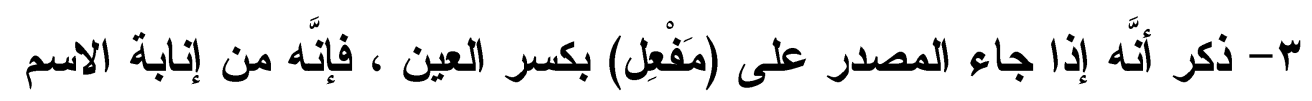

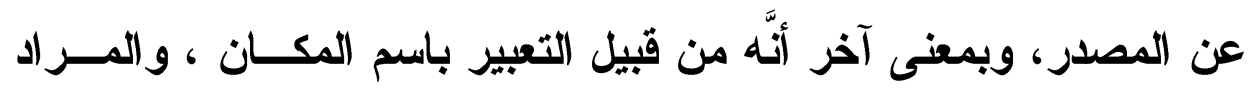

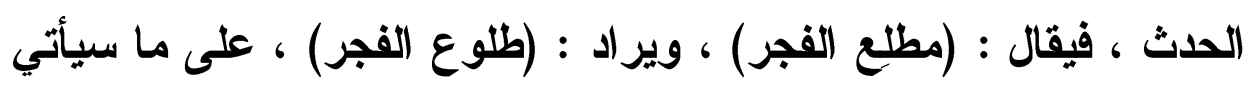
في تحليل القضية.

ع - نسب ذلكك أبو زرعة للفراء ، و استحضر نص كلامه من مؤَلَفه (معساني (القرآ).

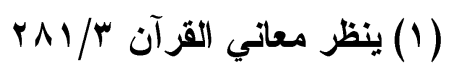

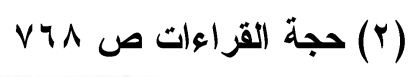


الترقير الدولخ ISSN 2356-9050

الدراسة والتهيل : - التيل

مقتضيات البحث ودراسة القضية هنا أن أتناول ذات المحسـاور التــي

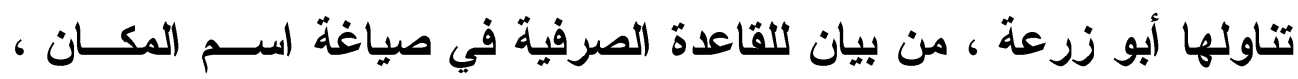

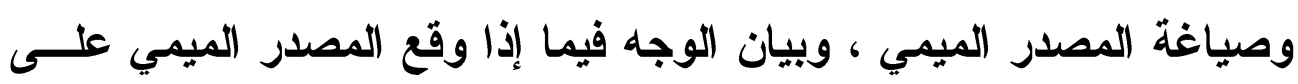

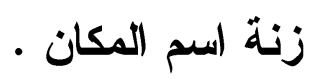

وقد طرحت هذه المحاور لاراستها من خلا كتب الصرف ، فلم أجـــ

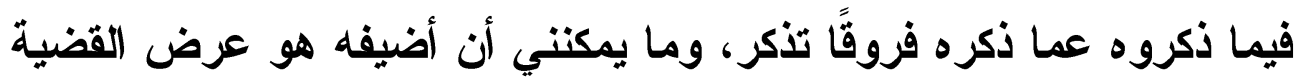

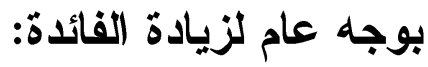
أولاً : القياس في صياغة اسم المكان ، ومثلّه اسم الزمان .

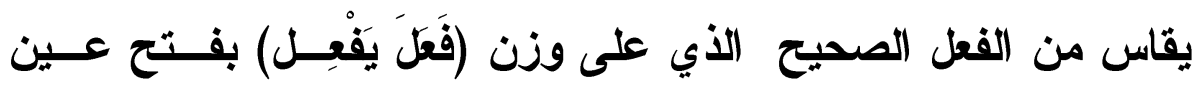

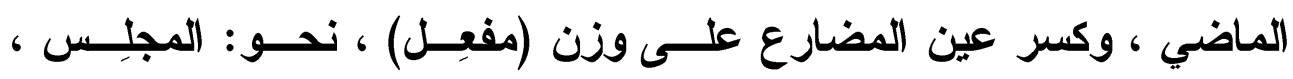

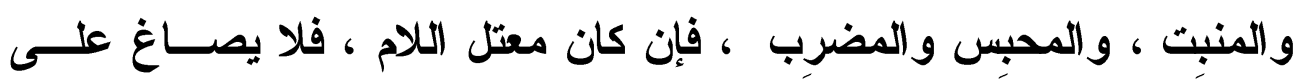

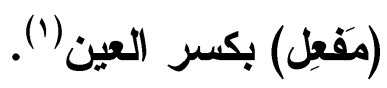
فإذا اعتلت لامه نحو: (دعا يدعو) ، و(رمى يرمي) ، فإنَّما يصــاغان

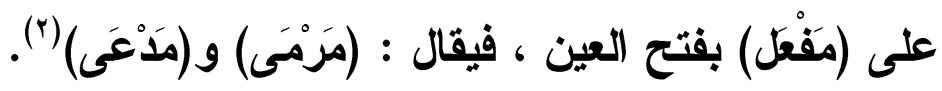
ثانيًا : العلة في كسر عين اسم المكان و الزمان من (فعل يفعِـل) فــي الفعل الصحيح الآخر.

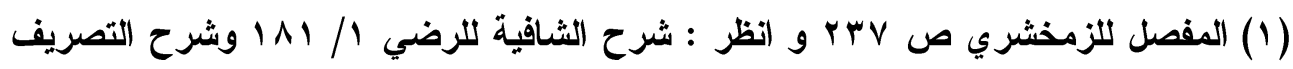

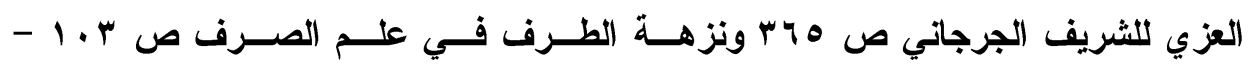

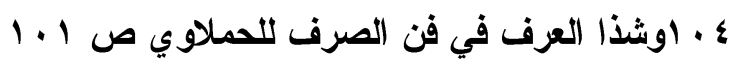

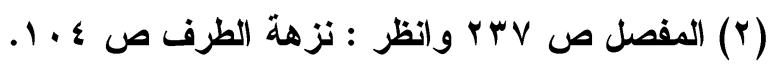


التّقتيباتُ التّحويةٌ والصّرفية

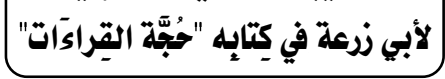

rivo

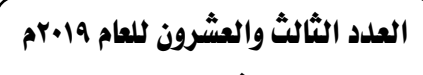

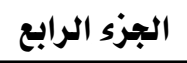

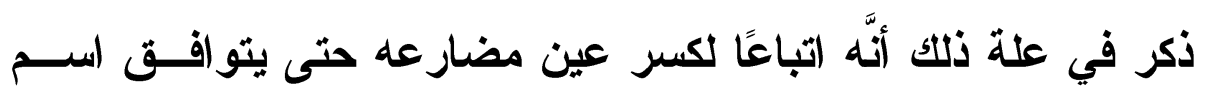

المكان و الزمان و المضارع في عينهما' (1).

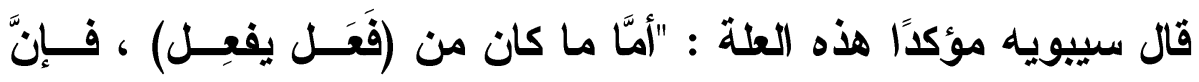

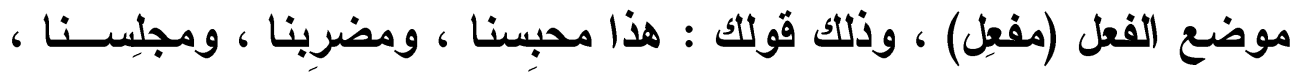

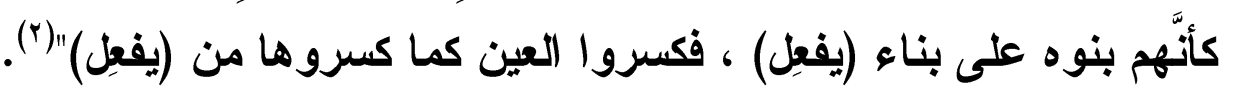
ثنالثًا : القياس في مصدر (فعل يفْعِل) .

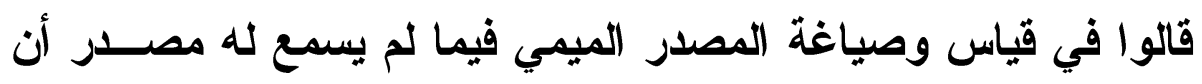

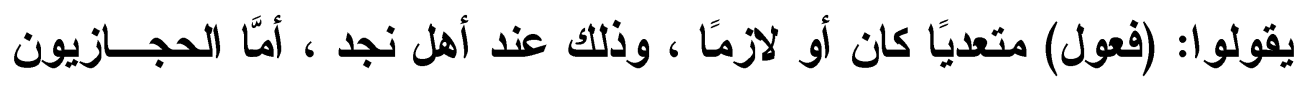

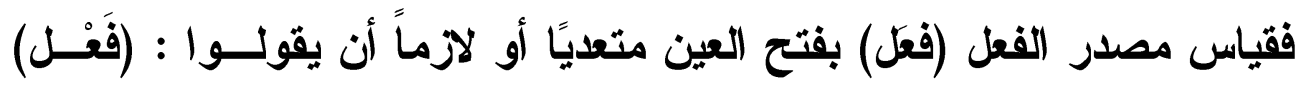

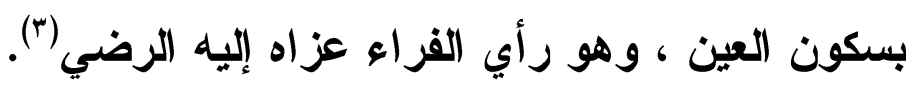
أمَّا الرضي فقد فرق بين صياغته من المتعدي ، وصياغته من اللازم ،

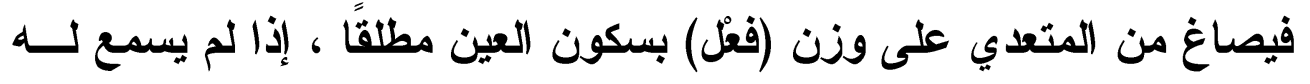

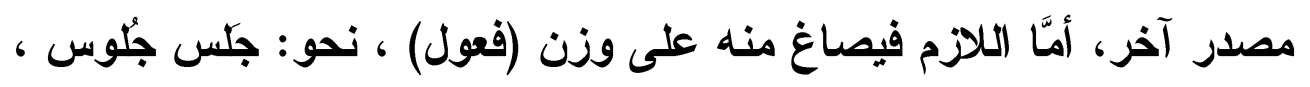

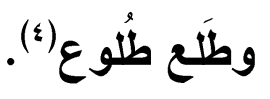

وبه قال ابن مالكك ، وهذا نصه : "وفي اللازم من (فَعِل فَعل) ومن (فَعَل

فمول)"(0)

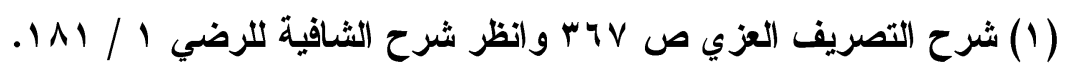

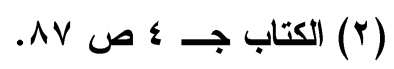

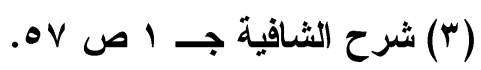

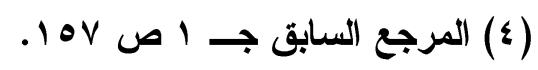

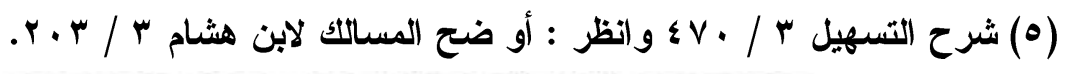




\section{الترقير الدولخ \\ ISSN 2356-9050}

أمََّّا صياغة المصدر الميمي : فإنَّهَه يصاغ على (مَفْكل) بالفتح ، والعلة

في ذلك لكي يغاير اسم المكان ، واسم الزمان في صياغته من الفعل ذاته.

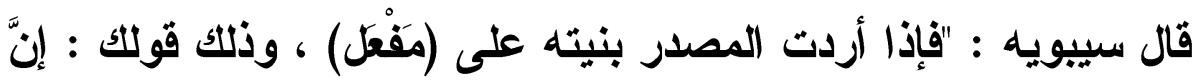

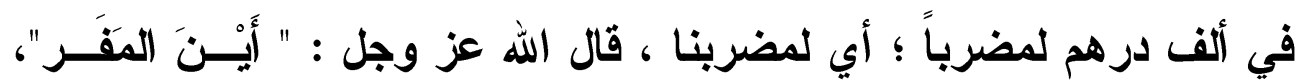

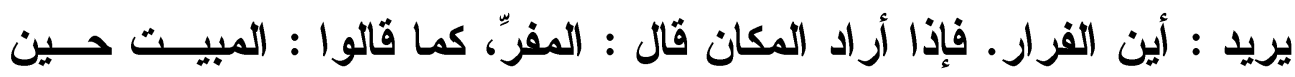

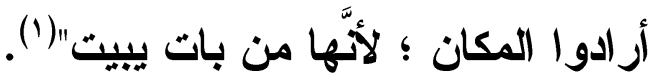

رابعًا : رأي النحويين في مجيء المصدر من (فَعَل يفعِل) على مفعِل بكسر العين.

ذكر النحويون أنَّهُ إذا جاء المصدر على (مفَفْلَ) في صورة صيغة اسم

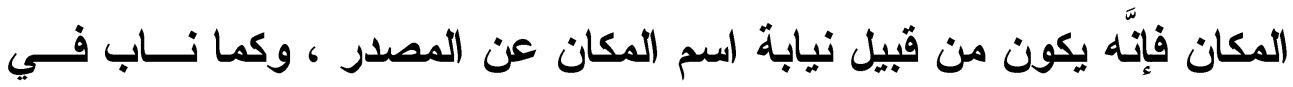

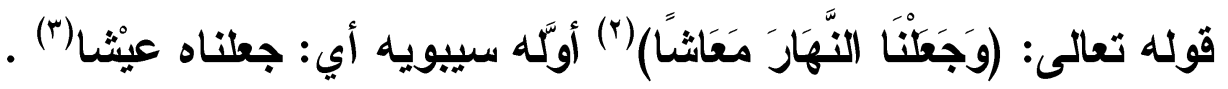

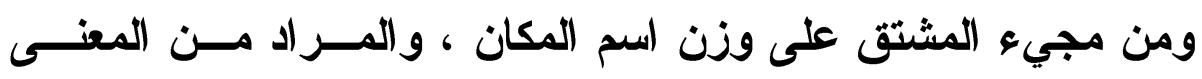

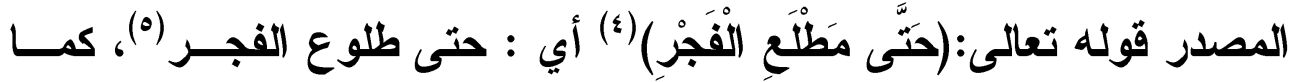
فسره .

بينما يرى العكبري : أنَّ (مَطْعَ) بالفتح ، و(مَطِِْعِ) بالكسـر لغتــان

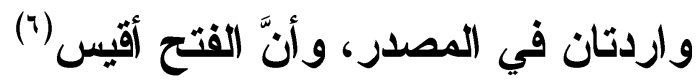

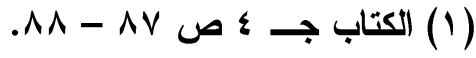

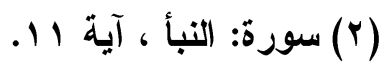

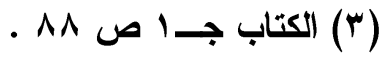

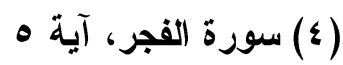

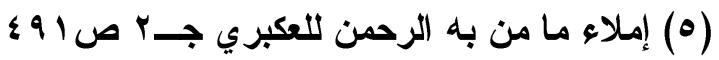

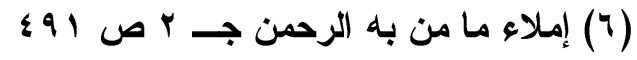




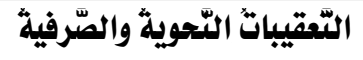
لأبي زرعة في كِتابه "حُجَّة القِراءَاتَ"
rivV

IIVV

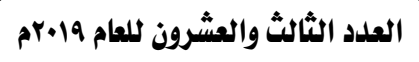

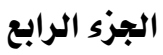

\section{خامساً: : رأي الفراء.}

قد أفردت الحديث عن رأي الفراء هنا نظرًا لتناول أبي زرعة لرأيه في

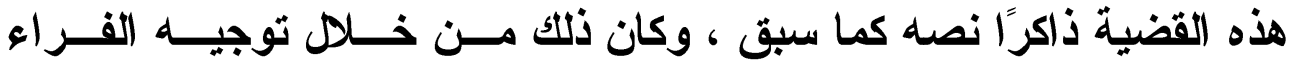

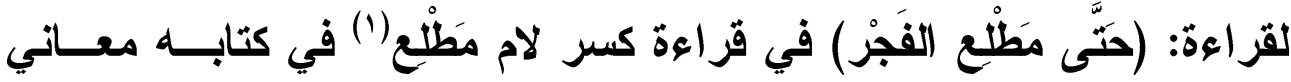

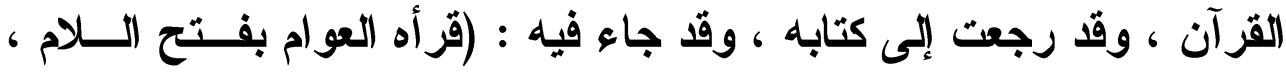

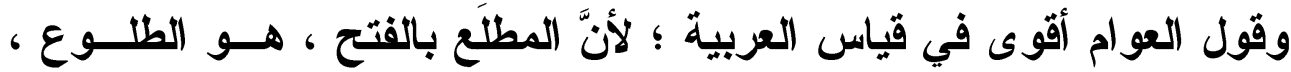

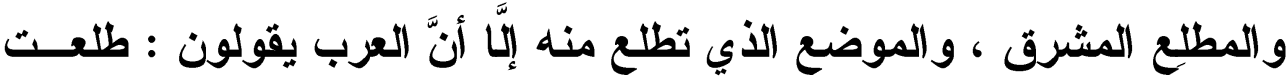

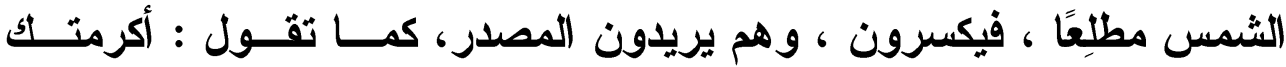

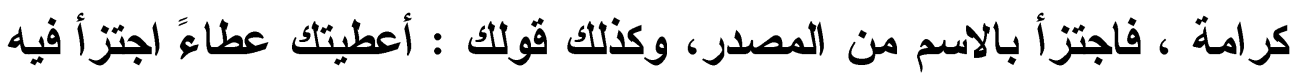

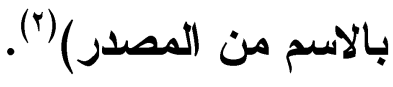
تحليل كلاهه : لاحظت في كلامه عن هذه القضية ما يأتي : وجود اختلاف بين هذا النص وبين ما أورده أبو زرعة فيما نقله عن الفراء وللقارئ أن يلحظ هذا الاختلاف دون الحاجة الى إعادة النصين ، ففي

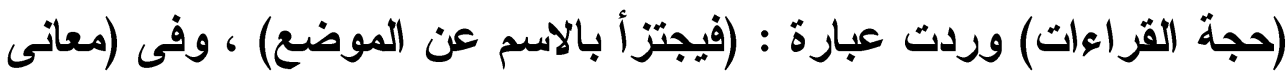
القرآن) للقراء (اجتزأ فيه بالاسم من المصدر) .

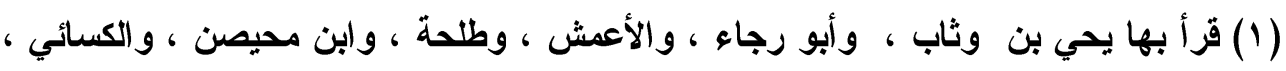

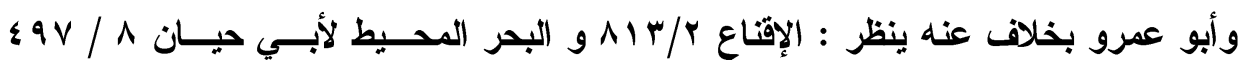

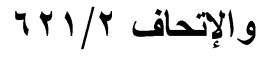

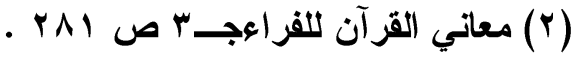




\section{الترقير الدول\$ \\ ISSN 2356-9050}

وللتوفيق بين النصين أقول : إنَّ ما جاء فيما أورده أبو زرعــة كــان المقصود اجتزاء منه (نيابة الموضع ، وهو اسم المكان عن المصــدر فــي

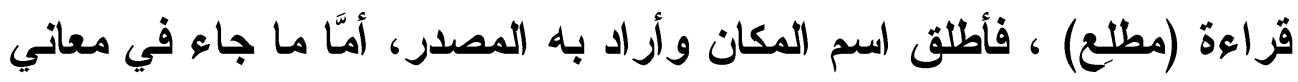

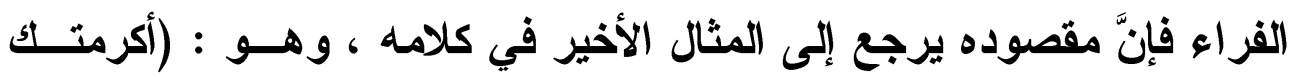

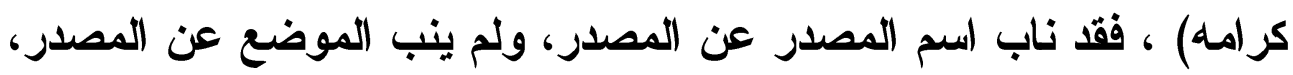
والله أعلم.

و القضية في مجملها محل اتفاق في صياغة اسم المكان والمصدر من

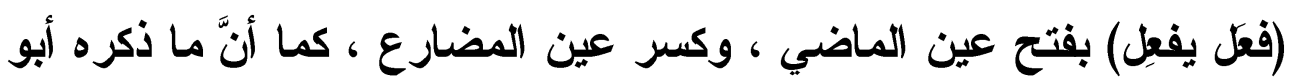

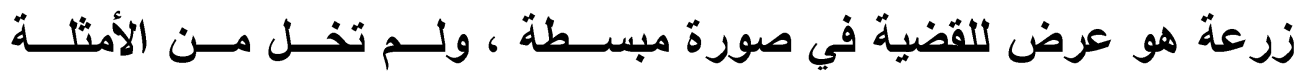

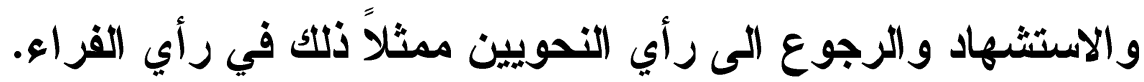




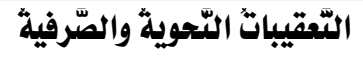

لأبي زرعة في كِتابه "حُجَّة القِراءَاتَ"

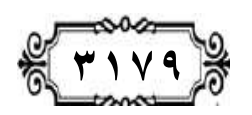

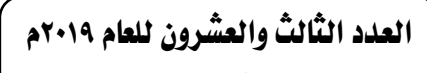

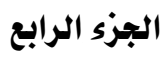

\section{باب الإعلال}

\section{1 - هجيء لغتان في (هينّ) بالتففيف والتشديد.}

قال أبو زرعة : " أصل الكلمة (مَيْوت) على وزن (فعيل) ، فقلبوا الواو يــاءًا

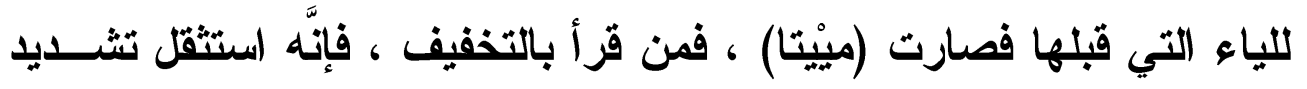

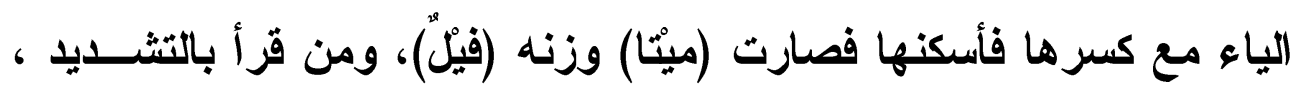

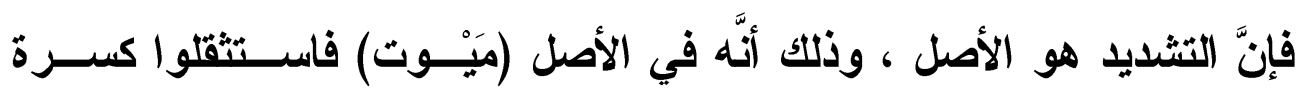

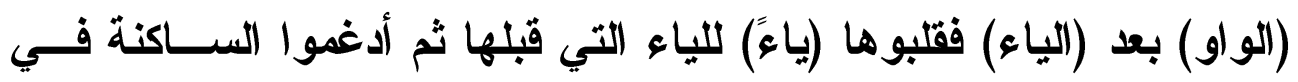

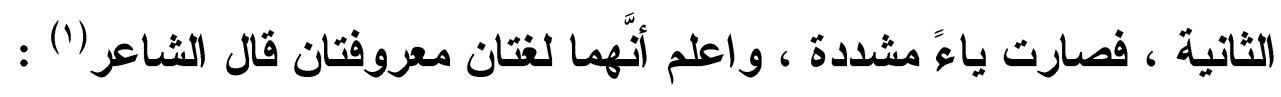

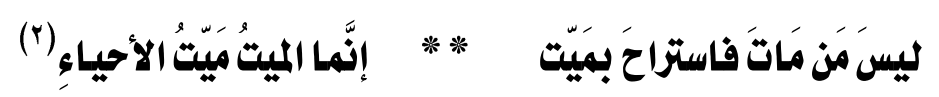
ما تضمنه كلامه من أفكار: 1 - ذكر أبو زرعة ما ورد في الوصف (ميث) من لغات عن العرب. فقد ذكر أنَّ فيه لغتين : الأولى : (ميْت) بالتخفيف بياء واحد ووزنه (فيلّ) بحذف عين الكلمة ، وهي

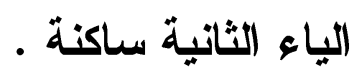
اللغة الثانية : (ميِّ) بالتشديد.

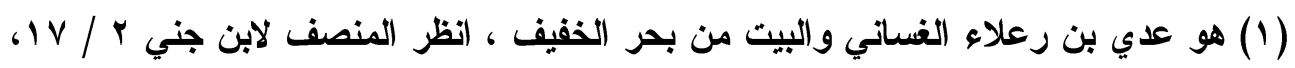

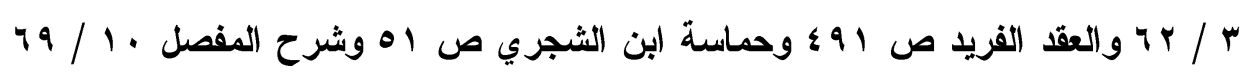

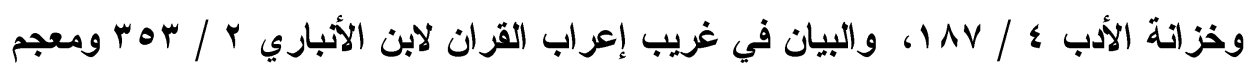

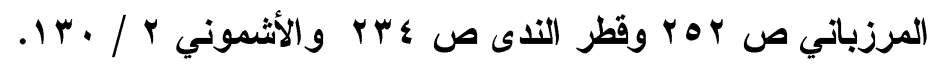

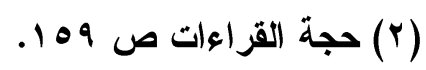




\section{الترقير الدولخ}

ISSN 2356-9050
Q.
حولية كلية اللفة العربية بجرجا مجلة علمية محكمة

r - ذكر أنَّ أصل اللغتين واحد وهو (ميوت) على وزن (فيعل) . ب- ذكر أنَّ علة التخفيف مجيئه بياء واحدة وهو الميل إلى التخفيف. ع - ذكر أنَّ التخفيف مخالف للأصل مع وروده ، وقا حـــث فيــه إعــله بالقلب، ثم بالحذف ، فقلبث الواو ياء ، ثم حذفت الياء الثانية.

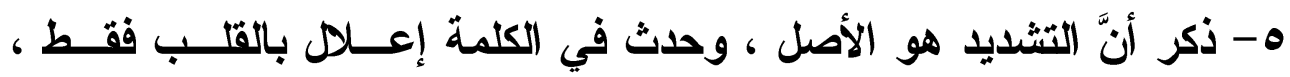
فالأصل (ميوت) قلبت (الواو) المكسورة (ياء) لوقوعها بعد (ياء) ثم اجثمع ياءان الأولى ساكنة ، والثانية متحركة ، فوجب الإدغام فصارث : (ميِّت). צ- ذكر أنَّ اللغتين وردتا في قول الشاعر السابق.

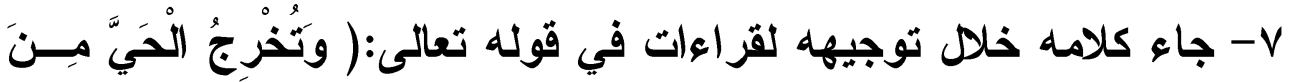

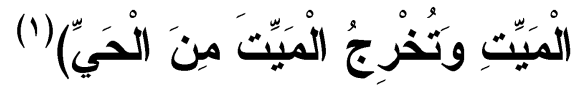

\section{دراسة القضية وتهليلها :}

يجدر بي هنا أن أذكر القاعدة الصرفية ، والتي من شأنها أن توضــح لنــا مدى إلمام الإمام أبي زرعة بمسائل الصرف. فالقاعدة في هذه المسألثة تقول : (إنَّ مواضع قلب الــواو يـــاء ، أن تجتمع الواو مع الياء في كلمة وتسبق إحداهما بالسكون ويتأصل ذاتاً نحو : سيِّّ ، والأصل : سيود ، وميت ، والأصل :ميوث ، فتقلب الواو ياء ، وتدغم الياء في الياء ؛ لاجتماع ياعين (r).

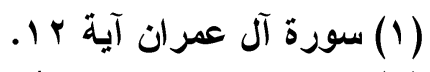

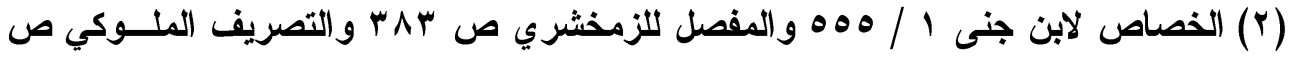

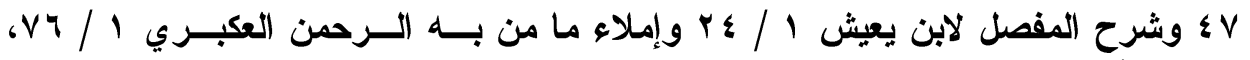

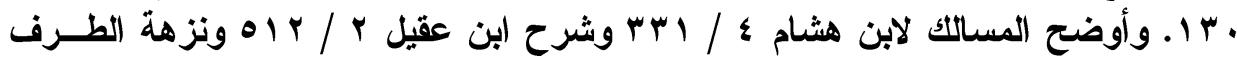

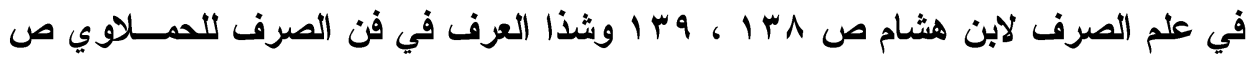

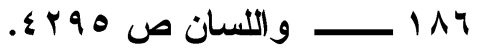

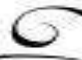




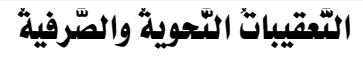

لأبي زرعة في كِتابه "حُجَّة القِراءَات"
0.

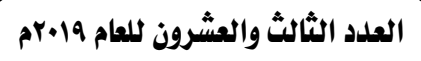

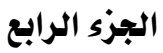

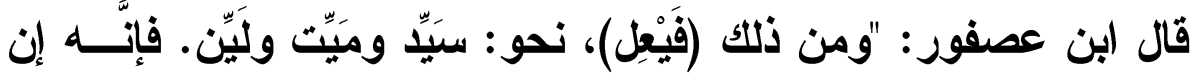

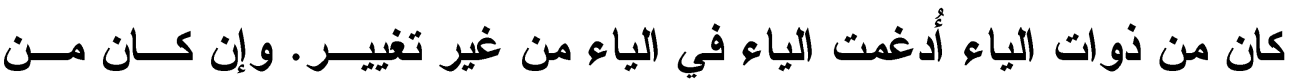

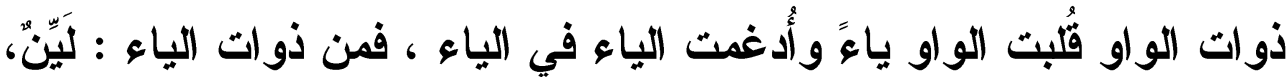
ومن ذوات الواو: سَيِّدُ ومَيِّت" (1). العلة في قلب الو او ياء وليس العكس. أمَّا عن بيان العلة في قلب الواو ياء في هذا الموضع ، فقد ذكر فيه

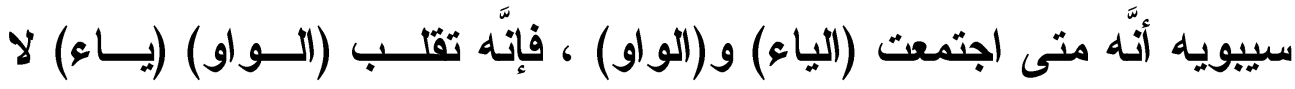

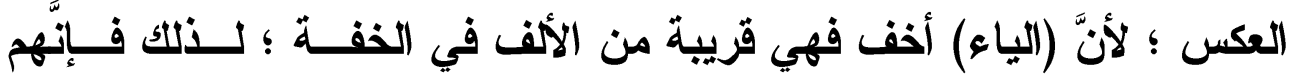
يقلبون في الوصف المعتل كسيد ، وميت ، ولا يقلبون فــي غيــر المعتـلـل ككينونة ، رغبة في التخفيف ، كما نقل ذلك عن الخليل (ץ).

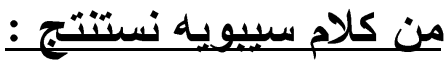

1- أنَّ التخفيف أيضًا كان هو الداعي لثيئين : قلب (الــواو) (يـــاء)

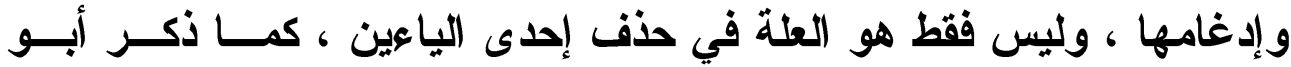

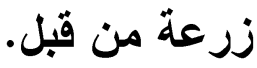

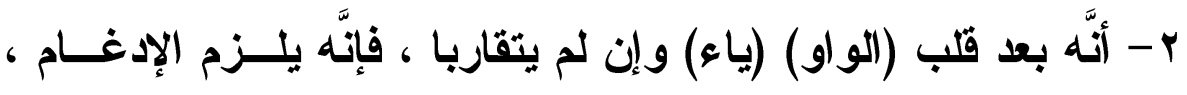

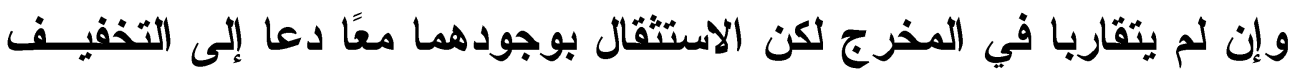

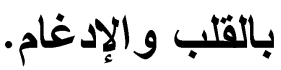

قال الرضي مبينًا العلة في ذلك ومؤكدًا ما سبق : "لكن لمــا اســتثقل

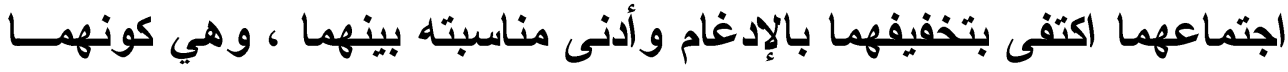

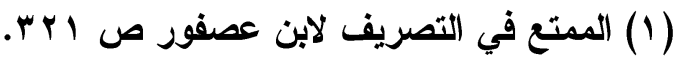

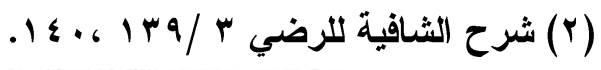

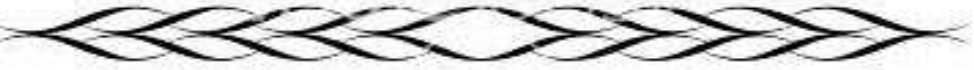




\section{الترقيم الدوله \\ ISSN 2356-9050}

من حروف المد واللين وجرأهم على التخفيف الإدغامي فيهما ، كون أولهما ساكناً ، فإنَّ شرط الإدغام سكون الأول ، فقلبت (الواو) إلى (الياء) ســواء

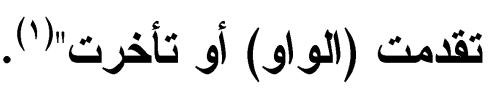

(ميَّت وميْت ) والحكم عليها بين القياس والسماع :

وقد لقت الرضي النظر إلى أمر مهم ، وهو أنَّ القياس في إدغام المتقاربين أن يقلب الأول إلى الثاني ، ولكن حدث في (فيعل) نحو: (سيّّ ، وميّت) كان العكس ، فلم تقلب (الياء) (واوًا) ، وتدغم الواو في الواو، والعلة في ذلــــ

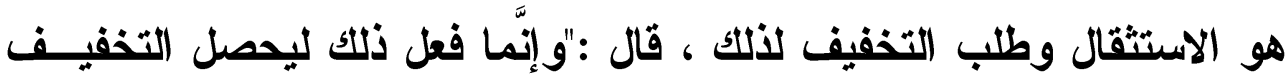
المقصود ؛ لأنَّ (الواو) و(الياء) ليستا بأثقل من (الواو) المضعَّةة"(r). وعليه لو جرى الأمر على القياس لكان ينبغي أن يقال : (مــوت) ، ولكن ذلك لم يحدث ؛ لأنَّ (ميوت) من غير قلب ، ولا إدغام أخف من (موّت)

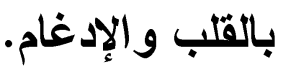

وعليه فالإعلال في ميوث (فيعل) واجب ؛ لأنَّهَ وصــف مسن الفعـل

(فَعَل) بالكسر والوصف يجب إعلالهه من هذا (الفعل(r).

وهذا الوزن وهو (فيعل) لا يكون إلَّا في الأجوف(๕). أمَّا تخفيف (ميْت) وجعلها بياء واحدة ، فهي لغة واردة ، وهي مخالقة للأصل ولكنَّها قياسية ، وحذفت فيه عين الكلمة.

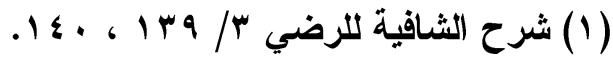

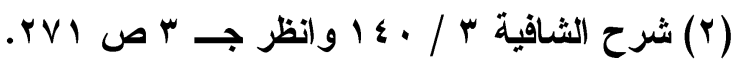

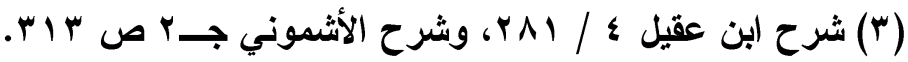

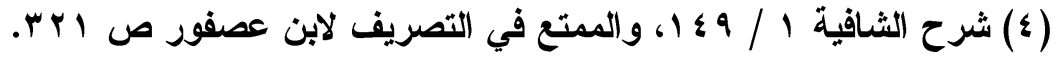



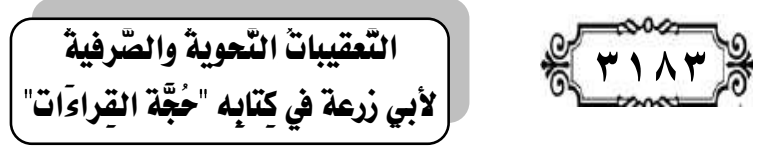

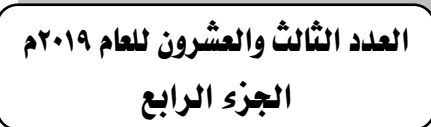

وقد ذكر الفارسي في قياسه أنَّا يجوز أن يقال في (بيّن) (بيْن) قياستسا

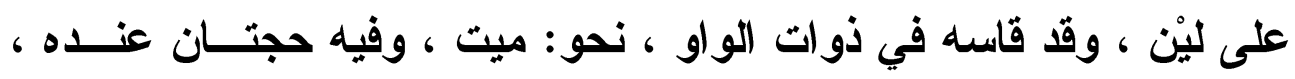

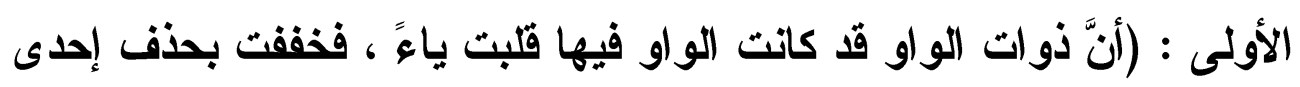

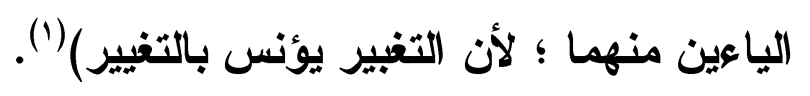

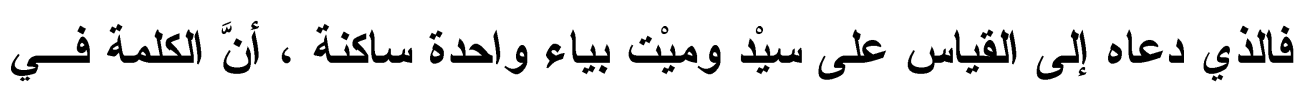

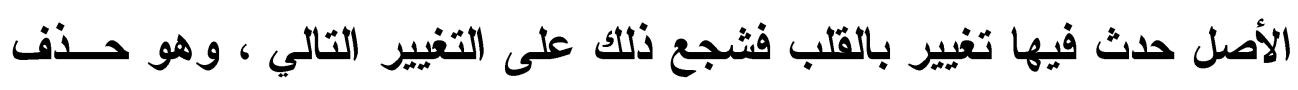

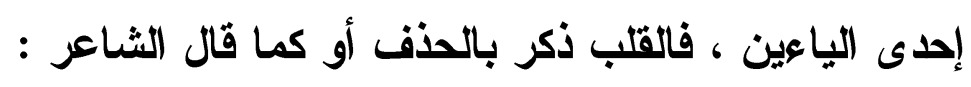

ذَكَّرتني الطعنَ وكنتُ ناسيًا

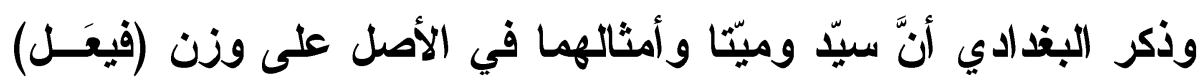

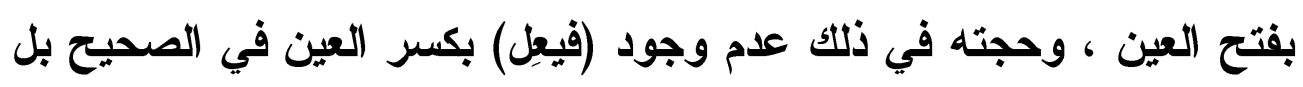

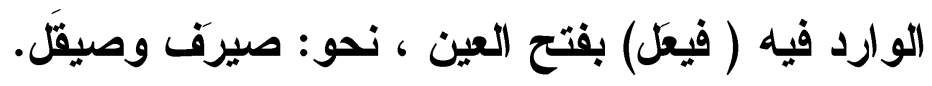

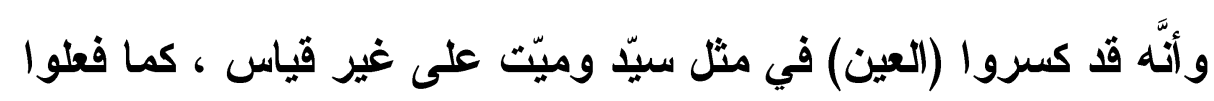
في النسب إلى البصرة ، فقالوا : بصِصري بالكسرة. وقد ردَّ ابن عصفور على ذلك بالآتي : 1 - بأنَّهُ لا ينبغي أن يحمل على الثذوذ ما أمكن.

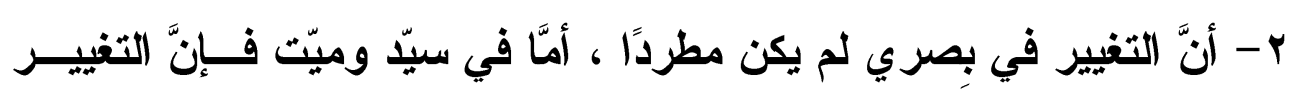
فيهما وأمثالهما مطردًا.

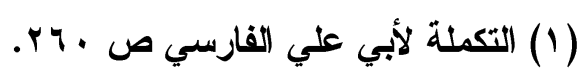

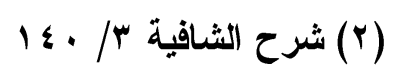




\section{الترقير الدولد \\ ISSN 2356-9050}

r- أنَّ عدم وجود (فيعِل) بكسر العين في الصحيح لا يوجـب الادعــاء أنَّ (فيعِل) بكسر العين في المعتل أصله مفتوح العين ('). وفي رده إيفاء و إفهام للقارئ والمتعلم. ميْت بالتخفيف ، وميّت بالتشديد من حيث المعنى: أغرى بعض المفسرين والنحويين مجيء ميت بلغتين تخفيـف اليــاء

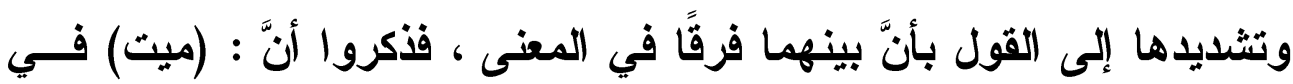
لغة التخفيف، يطلق على من مات حقًا واقعًا ، أو من مات كما هو مشهور. أمَّا (ميّــث) في لغة التشديد يطلق على من سيموت.

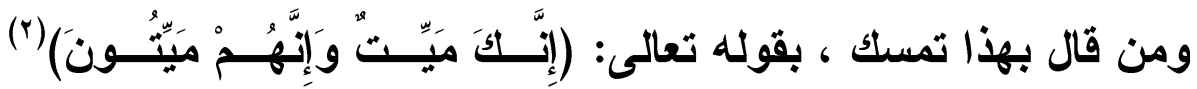
بالتشديا ، فإنَّ المخاطب هو الرسول - صلى الله عليه وسلم - كان حيًا لـــ يفارق الحياة ، وجاء المعنى والكلام ، إنَّك ستموث ويموتون (ّ). وحكم ابن الأبباري بخطأ هذا القول ، وذكر أنَّ اللغتين بمعنى واحـــ ،

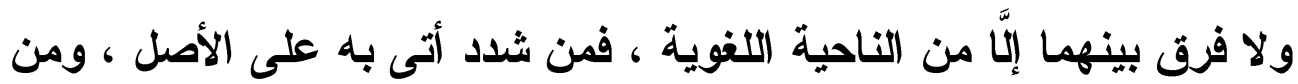
خفف حذف إحدى الباءين طلباً للتخفيف ، وقا استدلوا بقول الشاعر السابق عدى بن زعلاء : 20

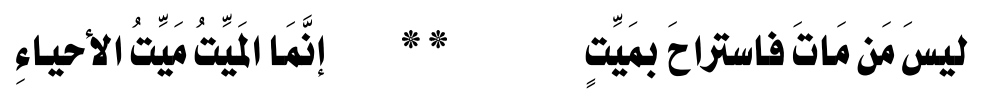

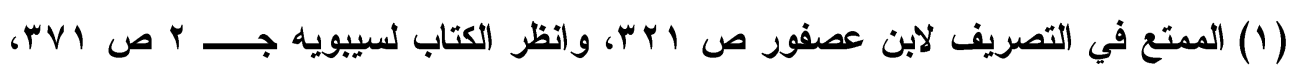

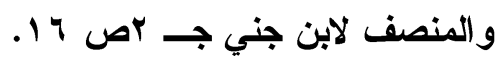

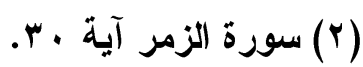

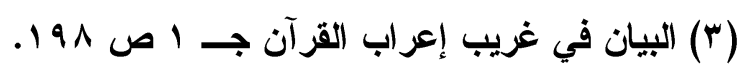


التققيباتُ التّحوية والصّرفية لأبي زرعة في كِتابه "حُجَّة القِراءَات"

\section{mino}

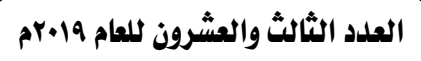

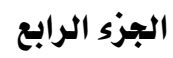

وجه الاستدلال أنَّ اللغتين وردتا في البيت ، ولم يحــف فيهمـــا المعنــي ،

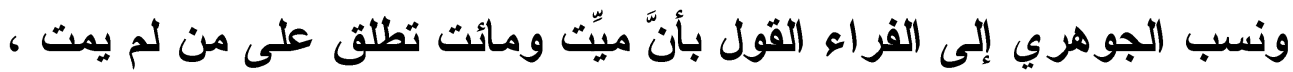

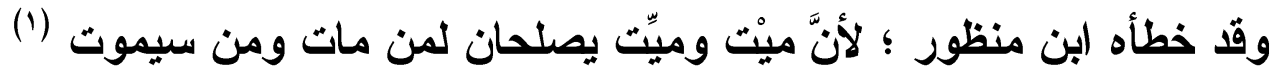

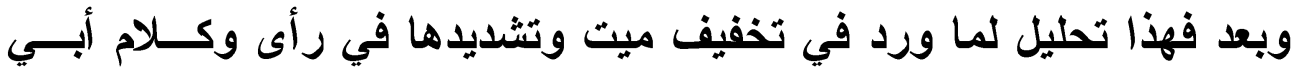

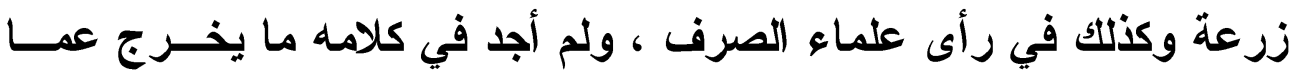
ذكره العلماء أو شذ عن القاعدة. 


\section{الترقير الدولم \\ ISSN 2356-9050}

\section{r - تخفيف الهمرتين إذا التقتا في كلمة واحدة}

قال أبو زرعة : "فإن قيل ما وجه تخفيف الهمزتين في (إألافهــ) ، قــــت :

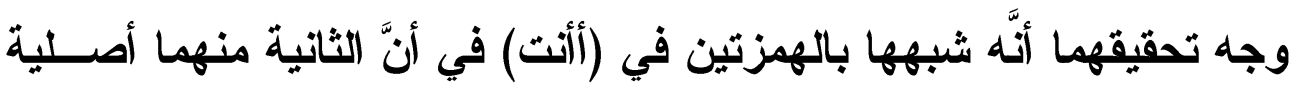

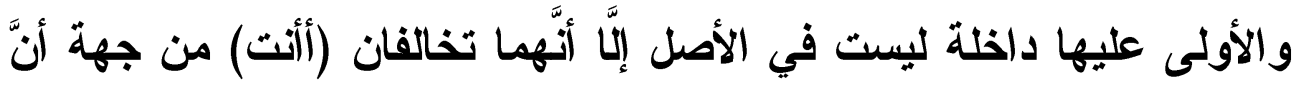

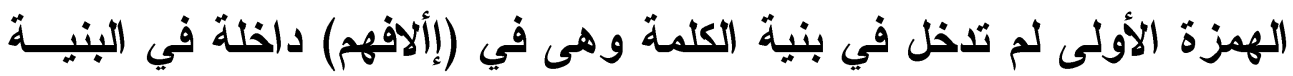

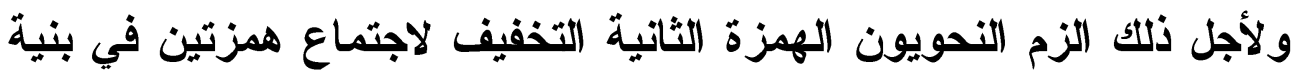

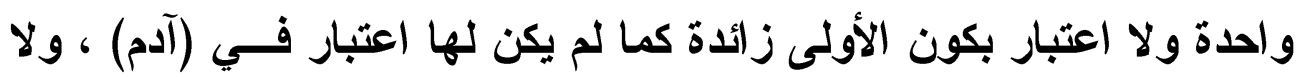

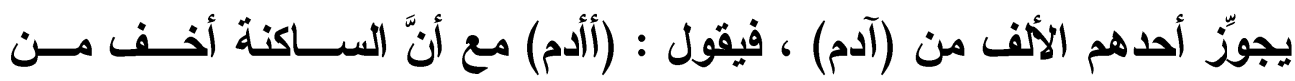

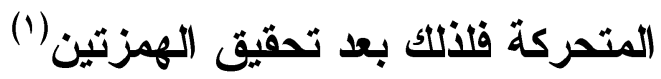
الأفكار التي تضمنها كلامه :

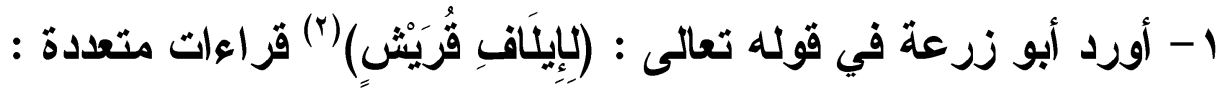

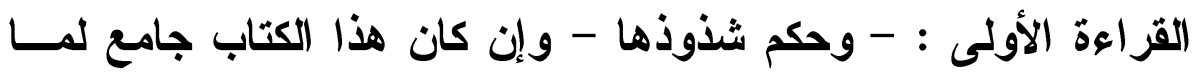

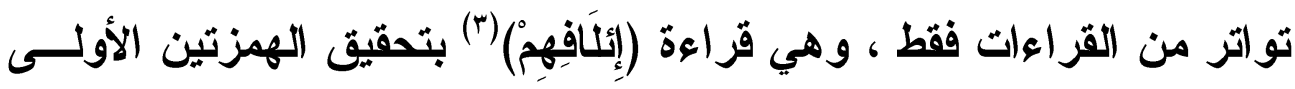

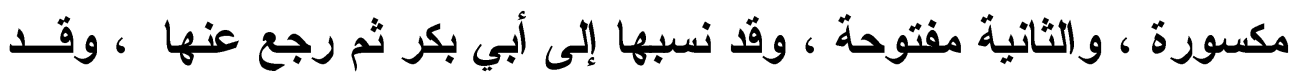
حكم أبو زرعة ببعدها.

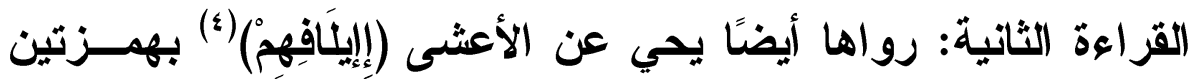
مكسورتين بعدها ياء ، وحكم أبو زرعة بأتَّها أكثر بعدًا من سابقتها.

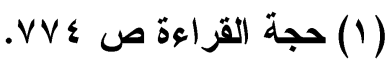

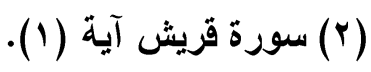

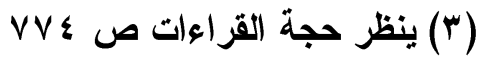
(؛) انظر مختصر في شواذ القرآن لابن خالويه ص صل ـ11 أ. 


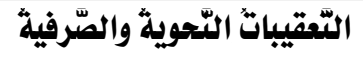
لأبي زرعة في كِتابه "حُجَّة القِراءَات"
Pinve

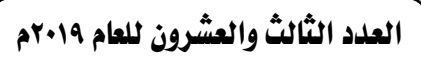

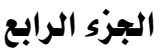

القزاعة الثالثة : وهي قراعة المصحف ( إيلافهر ) ، وهي قـر اعةة الســبعة

بتحقيق الهمزة الأولى وتخفيف الثانية بقلبها ياء. (1)

r - تحدث أبو زرعة عن رأي النحويين فــي قضــية تحقيـق الهـــتهين

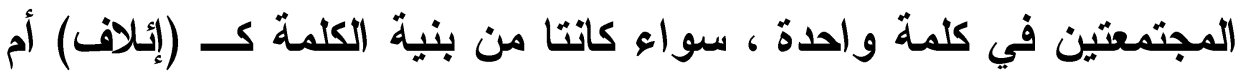

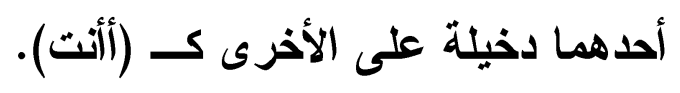

وفي عموم القضية نسب للنحويين أنهّهم لا يرون لتحقيـق الهـــتين وجهًا في العربية.

r - ذكر أبو زرعة على وجه الخصوص أنَّ النحويين اسـتبعدوا تحقيـق

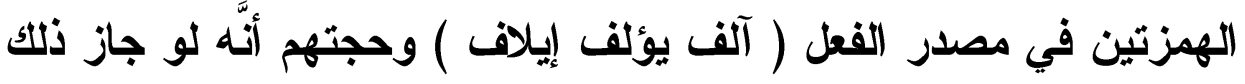

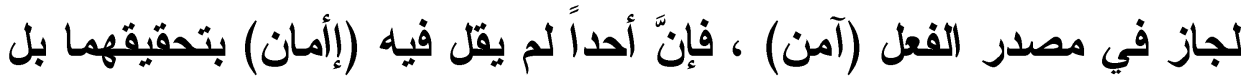

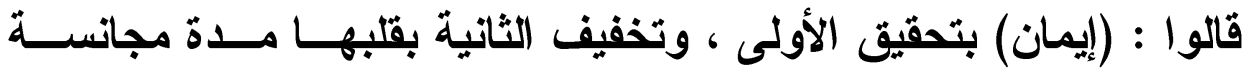

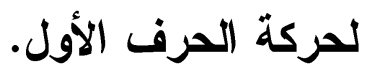

ع - ذكر أبو زرعة وجه تحقيق الهمزتين في القزاعة الأولى عند من قرأ بها

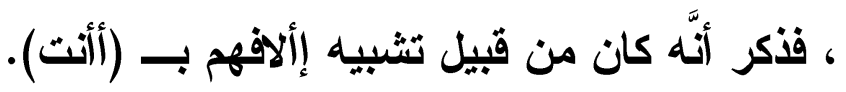

وقد أوضح ذللك الثبه في كلامه كما ذكر أنَّ بينهما فرقًا. ه- أنهى كلامه بالتزام النحويين بتحقيق الهمزة الأولى ، وتخفيف الثانية ،

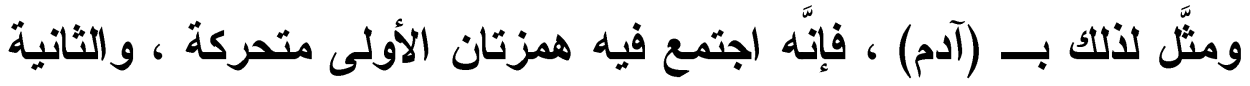

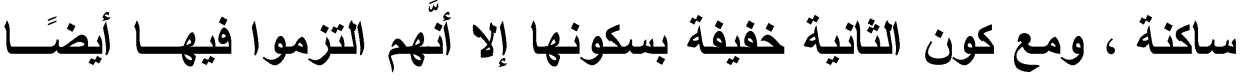

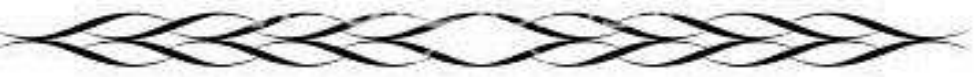




\section{الترقير الدولم \\ ISSN 2356-9050}

التخفيف ، فمن باب أولى التزام التخفيف في التهزة الثانية المتحركة من

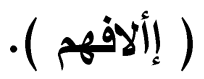

\section{توضيح قضية اجتماع الهمزتين في كلمة واحدة :}

يجدر بي قبل التفصيل في هذه القضية أن أذكر على سبيل الإجمال القاعـدة و القياس فيها.

فالقاعدة الصرفية أنَّه إذا اجتمع همزتان في كلمة واحدة فالوجه قلب الثانية إلى حرف لين كقولهم : (آدم)(') ، وهذا يعني تحقيق الأولى وتخفيف الثانية.

وعلى التفصيل لهذه القضية:

فإنَّ النحويين يرون أنَّهَ إذا اجتمع في كلمة همزتان وجب تخفيف الثانيــة ، إن لم يكونا في موضع العين ، قلهما حالتان :

الأولى : إن تحركت أولاهما وسكنت ثانيتهما، وجب إبدال الثانية مدة تجانس حركة الأولى.

فإن كانت حركتها فتحة أبدلت الثانية ألفًا نحو: (آثرت)، و(آدم)، و(آمسن)، وإن كاتت ضمة أبدلت واواً نحو: (أوثر)، و (أومن). وإن كانت كسرة أبدلث ياءً ، نحو: (إيثار)، و(إيمان).

الحالة الثانية : إن تحركتا ، فإن كانت حركتها فتحة قلبــث الثانيــة واواً ،

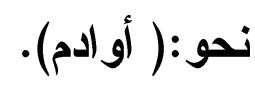




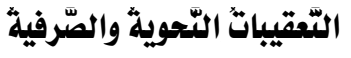
لأبي زرعة في كِتابه "حُجَّة القِراكَاتِ" एic 119

PIN9

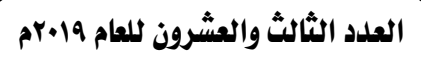

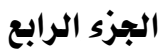

وإن كانت حركة الأولى ضمة ، و الثانية فتحة قلبــت واواً أيضًَـا ، نحـــو: (أويدم)

ويناءً على القاعدة ، فإنَّه ينبفي قلب الهمزة الثانية في (إألافهم ) ياء('). العلة في تحقيق الهمزة الأولى وتخفيف الثانية .

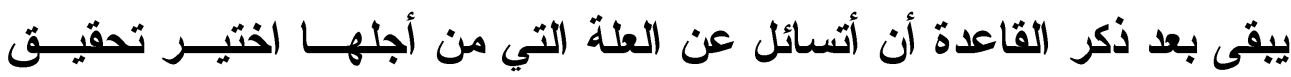

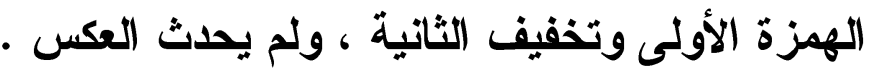
وأجاب عن ذلك كثير من النحويين، وعلى رأسهم سيبويه ، فإنَّه نفــى

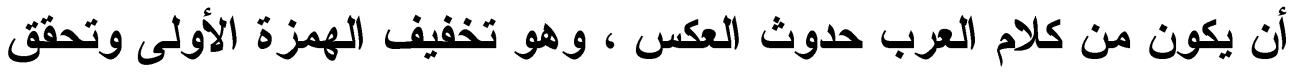

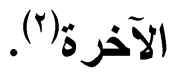

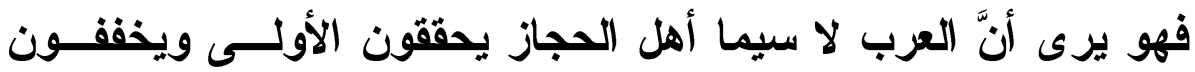
الثانية ، حتى إنَّ سييويه ذاته سأل الخليل عن علة ذلك ، فأجابــهـ الخليـل

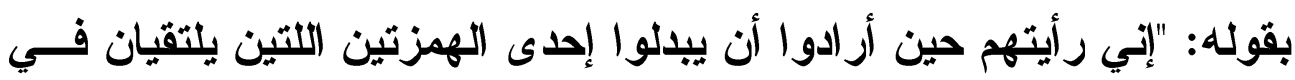
كلمة واحدة ، أبدلوا الآخرة ، وذللك نحو: جائي وآدم"(").

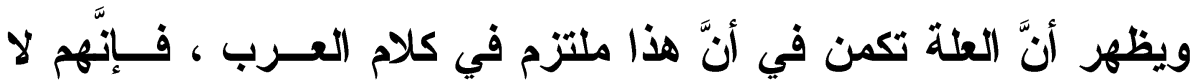

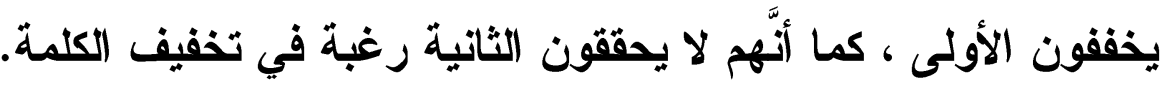
أمََّّ الرضي فقد ظهر في ذكره للعلة فهمه العميق لسمات الحــروف ، وضو ابط الصرف وعلله.

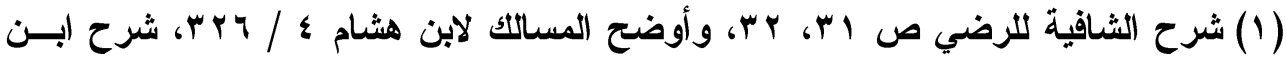

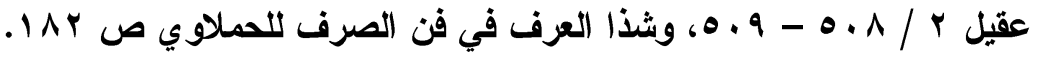

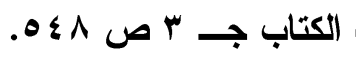

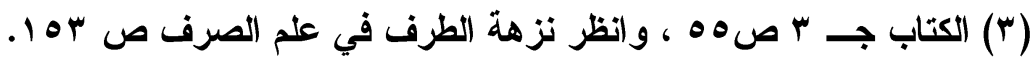


الترقير الدول\$ ISSN 2356-9050
(4) 19.

حولية كلية اللفة العربية بجرجا مجلة علمية محكمة

وأستطيع تلخيص رأيه في علة تخفيف الثانية في أمرين :

الأول : أنَّ الهمزة لهَّا كانت أدخل الحروف في الحلق ولها نبرة كريهة تجري مجرى التهوع ثقلت بذلك على لسان المتلفظ بها فخفقها قوم ، وهــم أكثر الحجازيين لا سيما قريش.

فقد روي عن على - رضي الله عنـه - أنَّهـ قال: "أنزل القــر آن علـى

قريش وليسوا بأصحاب نبر ، ولولا أنَّ جبريل نزل بالمهزة عنــ النبــي -

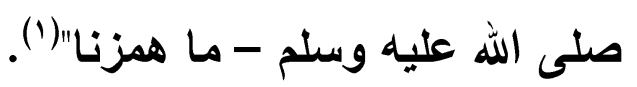

أمَّا غير الحجازيين فإنَّهم يحققونها(؟).

الأمر الثاني : وفيه ذكر العلة في اختيار الثانية للتخفيف وليست الأولى. فزكر الرضي أنَّ الثثقل حصل من الثانية.

ثم ذكر العلة في إبدالها من جنس حركة الأولى ، وهي الرغبــة فــي إحداث تجانس بين حركة الحرف الأول وبين جنس الحرف الثـــي فتخـف

بذلاك الكثمة)(r).

وأستطيع من خلال ما سبق استخلاص الآتي:

ا - أنَّ التحقيق هو الأصل ؛ لأنَّ الهمزة مثثلها مثُل سائر الحروف.

(1) تحقيق الأثر عن مراح الأرواح في علم الصرف لأحمد بن علي بن مسعود وشرحه لابـن

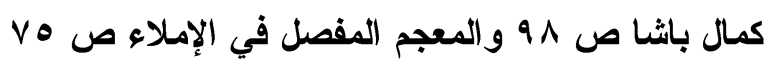

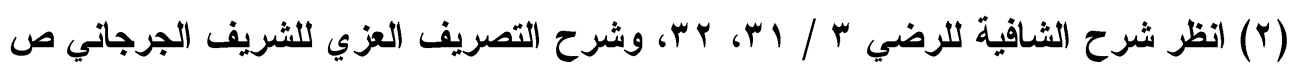




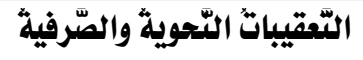
لأبي زرعة في كِتابه "حُجَّة القِراءَات"
\%. 191

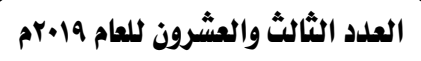

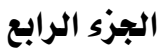

r- أنَّ الهمزة من بين الحروف لها خصوصية ، فقد فضل النحويون معهــا

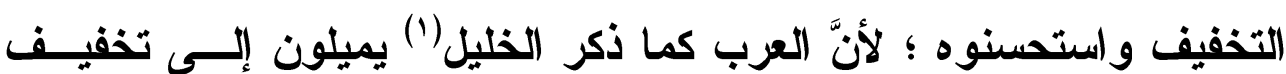

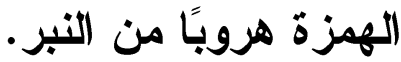

توجيه النحويين للقراءات الواردة بالتحقيق كقر اءة (إلافهم أو إإلافهم). حكم أكثر النحويين على تحقيق الهمزتين من مصــدر الفعـل ألــف ،

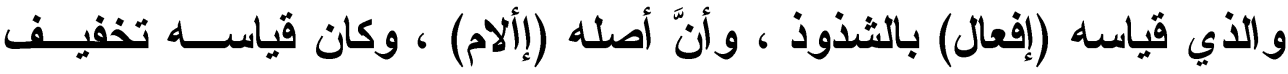

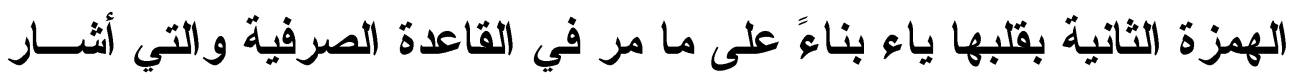

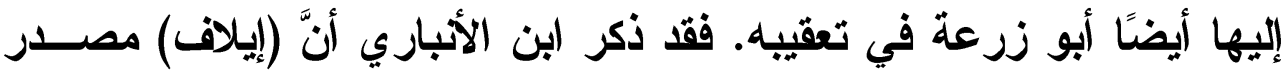

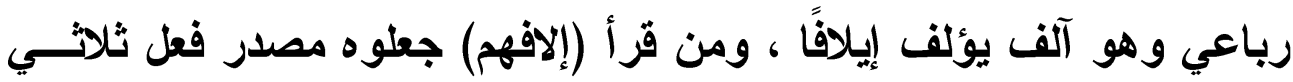

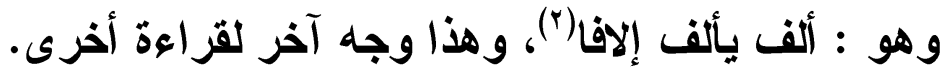
وقد ذكر العكبري في توجيه قراعة (إيلاف) بهمزتين بأنَّه خروج عـن الأصل ، وأنَّهَ شاذ في القياس و الاستعمال معًا(ّ). وهذا ما عليه أكثر النحويين(\&).

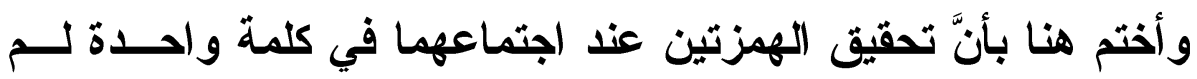
يسوغه العرب حتى في كلامهم ، ولم يجيزه النحويون في كتبهم ، ولم يقرأ

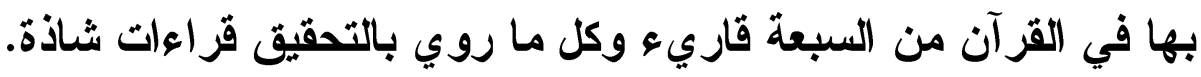

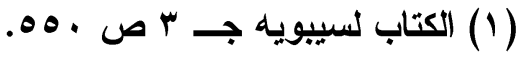

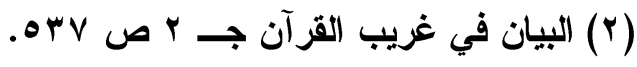

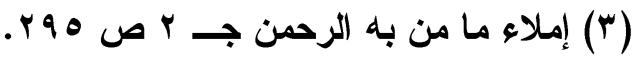

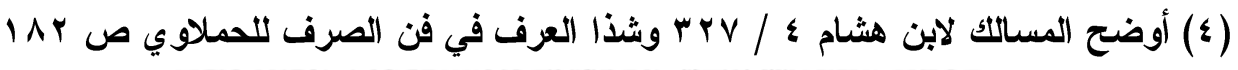

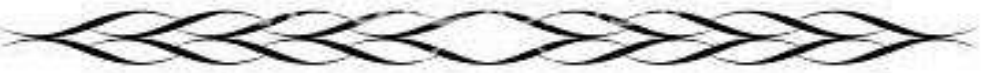




\section{الترقيم الدولم \\ ISSN 2356-9050}

\section{باب الإدغام}

\section{الإظهار والإدغام في الاضشارع الاضضاعف المجزوم}

قال أبو زرعة :(اعلم أنَّ الإظهار لغة أهل الحجاز، وهو الأصـل ؛ لأنَّ

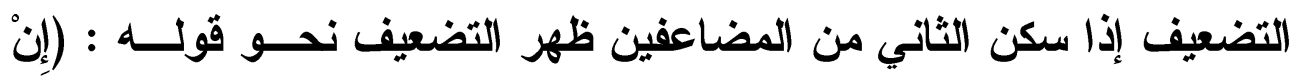

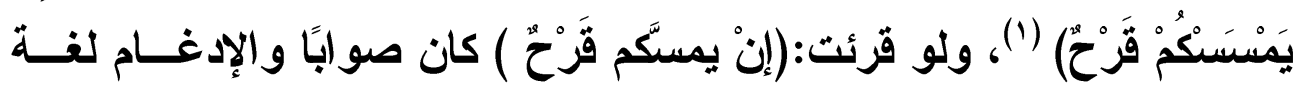

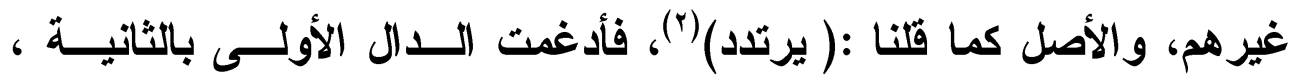
وحركت الثانية بالفتح لالتقاء الساكنين) (ب). ما تضمنه كلامه من أفكار:

1 - أورد أبو زرعة في المضارع المضاعف إذا جزم لغتين الأولــى :

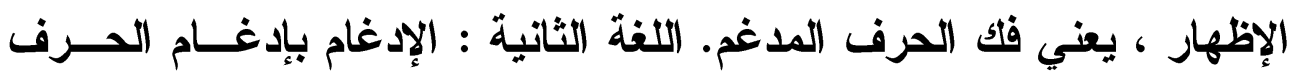
الأول في الثاني. r- ذكر أبو زرعة أنَّ الأصل في الفعل المضـــاعف المجـزوم ، هـــو

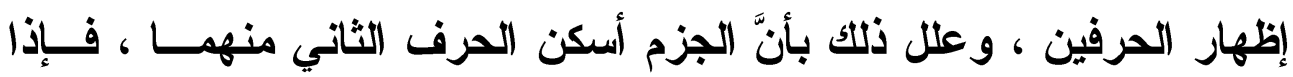

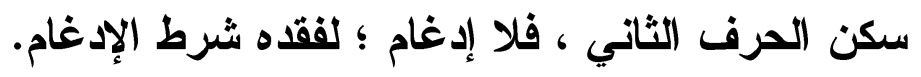
r- ذكر أبو زرعة أنَّ لغة الإدغام يترتب عليها تحريك الحرف الثاني

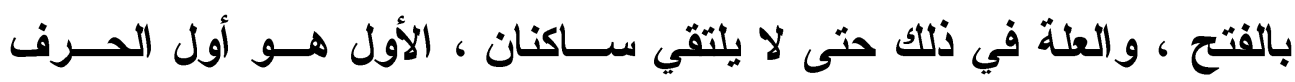
المضاعف و الساكن الثاني هو حرف الإعراب والجزم.

$$
\begin{aligned}
& \text { (1) سورة آل عمران من الآية . ع } 1 \text { (1) }
\end{aligned}
$$

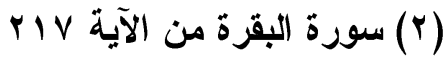

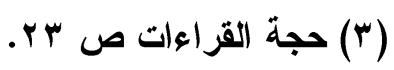


التعقيباتُ التّحوية والصّرفية لأبي زرعة في كِتابِه "حُجَّة القِراكَاتَ" rise

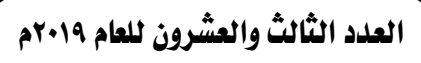

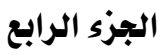

ع - ذكر أبو زرعة أنَّ الإظهار لغة أهل الحجاز، والإدغام لغة غيرهم.

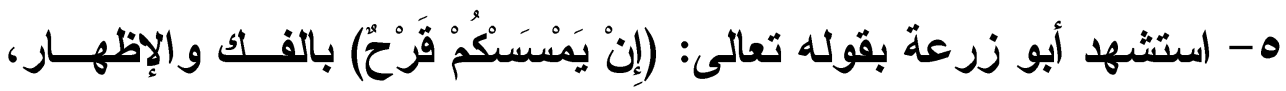

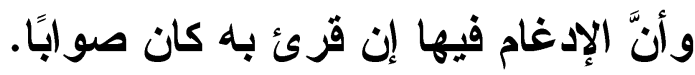
צ- كان كلامه في معرض توجيه قراعة (من يرتدد) (') بالقك. الدراسة والتحليل

مقتضيات البحث في هذه القضية تستدعي مناقثة وعرض الأمور الآتية : أولها : تعريف الإدغام ، وبيان الغرض هنه.

الإدغام هو : رفعك اللسان بالحرفين رفعة واحدة ، ووضعك إياه بهما

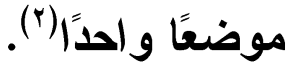

أو هو: الإتيان بحرفين ساكن فمتحرك من مخرج واحد ، بلا فصل(").

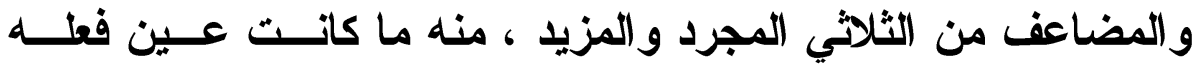

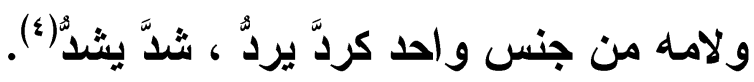

ويقال للمدغم الأصم ، وذلك نحو: مدَّ وشدَّ ، وامتدَّ واثتنَّ ، واسـتمرَّ

واستمدَّ(•).

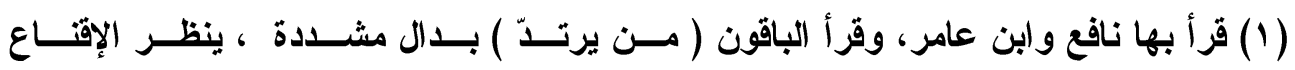

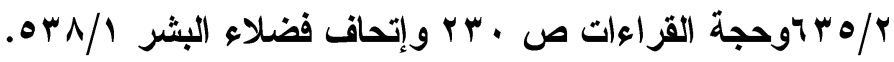

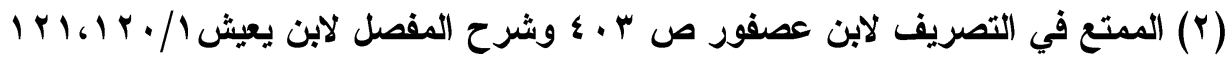

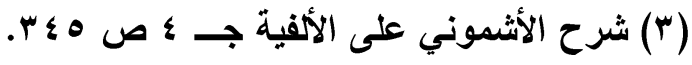

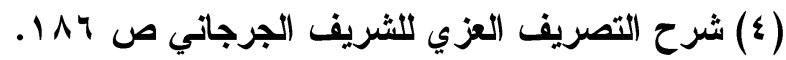

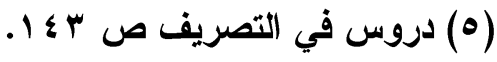


الترقير الدولخ

ISSN 2356-9050

و الغرض من الإدغام طلب التخفيف ؛ وذلك بسبب ثقل التقـــاء المتجانسـين على الألسنة ، فيعمد إلى الإدغام (1).

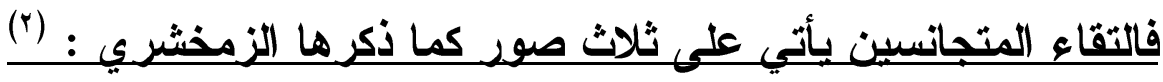
الأولى : أن يسكن الأول ويتحرك الثاني ، فيجب الإدغام ضرورة. الثانية : أن يتحرك الأول ، ويسكن الثاني ، فيمتنع الإدغام ويجب الإظهار. الثالثة : أن يتحركا ، فيمتنع أيضًا الإدغام(")

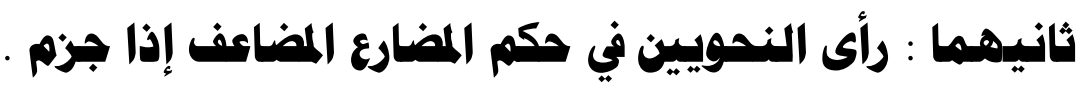
الأمر الثاني من الأمور التي يتطلبها البحث فـي هـــه القضــية أن أتناول حكم المضارع المضاعف اللام إذا جزم في وجهة نظر النحويين. فالقاعدة في هذه القضية أنَّه إذا جاء مضارع مضعف التلام مجزومَّـا جاز إظهار الحرفين وجاز إدغامهما ، وينطبق هذا أيضًا على الأمــر، فمــن

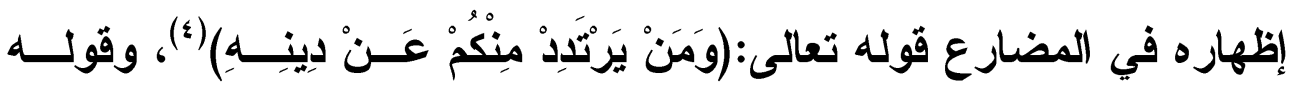

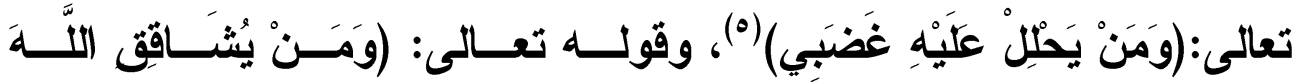

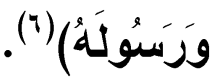

وهاتان اللغتان الإظهار والقك ، يجــوزان فــي المضـــارع المجـزوم المستتد إلى الاسم الظاهز أو الضمير المستتر جاز فيــهـ الإدغــام والفــــ ، تقول: لم يشدّ ، ولم يملّ ، ولم يخفّ ، وتقول : لم يشدد ، ولم يملـلـ ولــــ

(1) (المفصل للزمخشري ص س بq م. (r) المفصل ص r r r r.

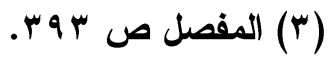

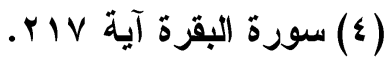

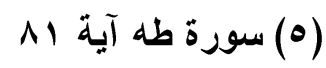

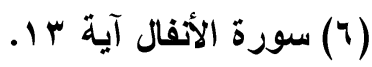



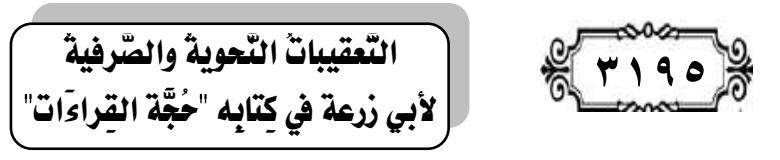

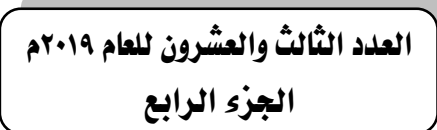

يخفف ، والفك أكثر استعمالاً وهو لغة أهل الحجاز (1)، كما ذكر في كلام أبي زرعة. - مان.

أمَّا ماضيه فالقاعدة الصرفية أنَّه يجب فيه الإدغام في مجردة ومزيدة

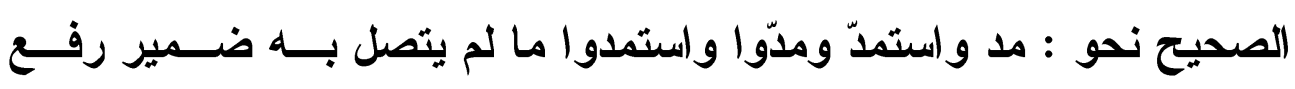

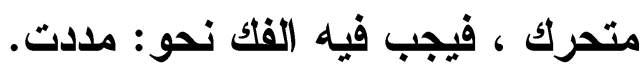

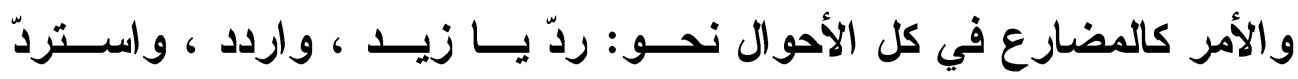

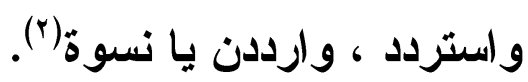

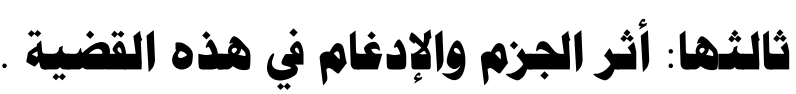
الأمر الثالث الأي يجب عرضه وبياته هنا أن أبين كيف كان للجزم أثر فئ

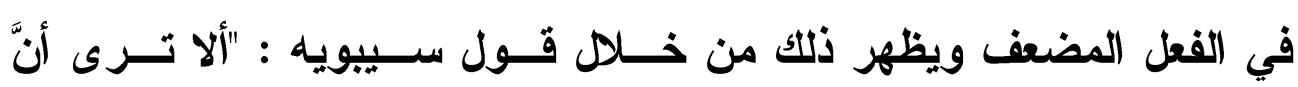

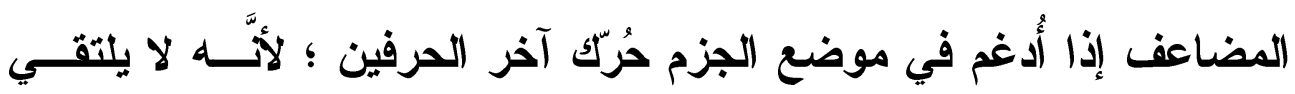

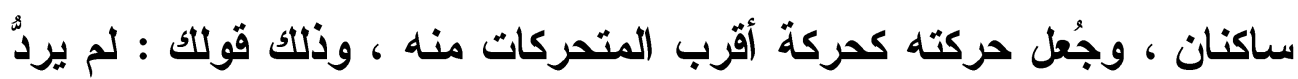

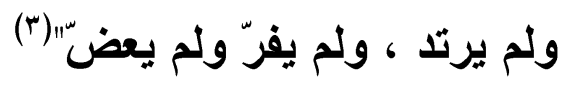

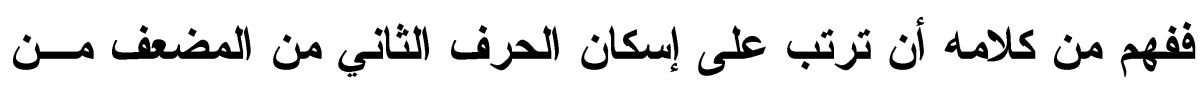

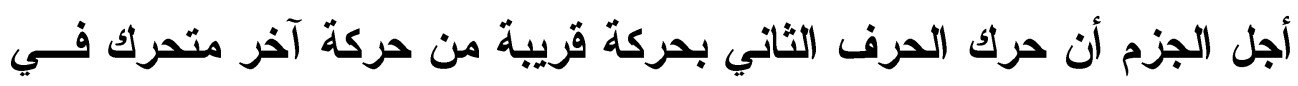

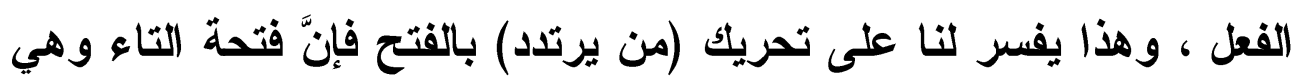

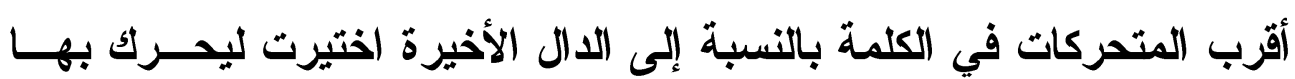
الحرف المدغم، فقيل : لم يرتدَّ بالقتح.

(1) دروس التصريف ص ب؟ أ ، وينظر : نزهة الطرف في علم الصرف لابن هشام الأصاري

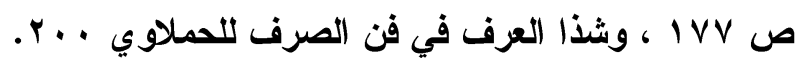

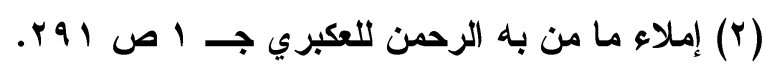

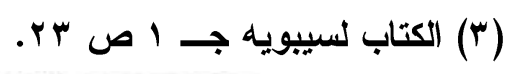


الترقير الدول\$ ISSN 2356-9050
P197
حولية كلية اللفة العربية بجرجا مجلة علمية محكمة

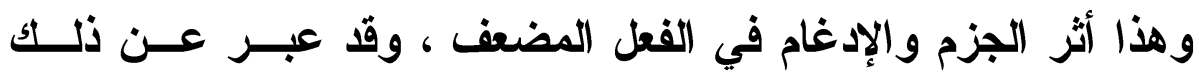

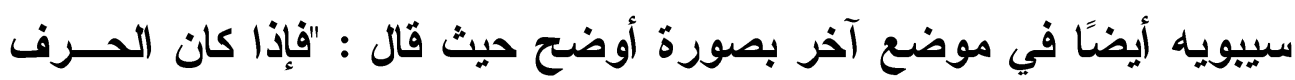

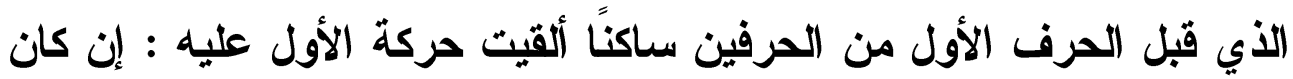

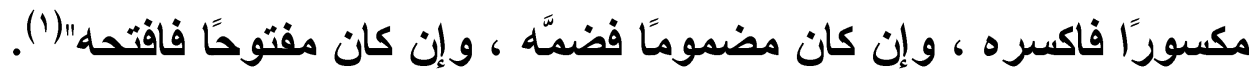

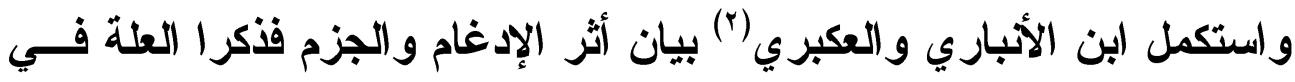

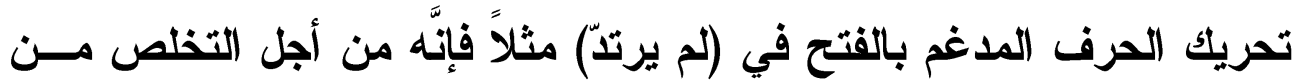
التقاء الساكنين (ז).

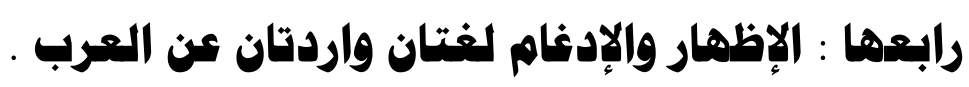

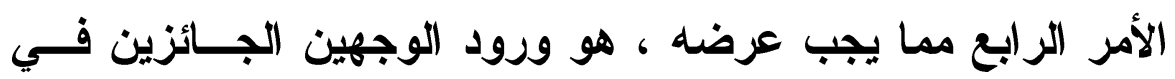

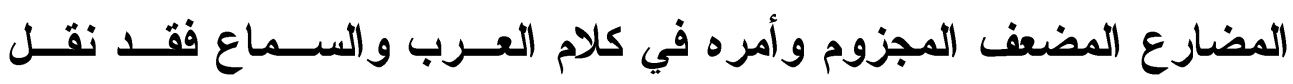

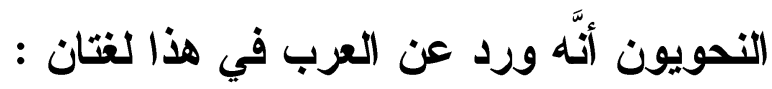
لغة الإظهار ، وهي واردة عن أهل الحجاز، كما حكى سيبويه وغيره من النحويين. قال سيبويه :"فإذا كان حرف" من هذه الحروف في موضع تسكن فيه

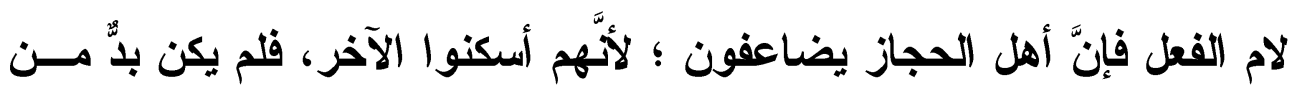

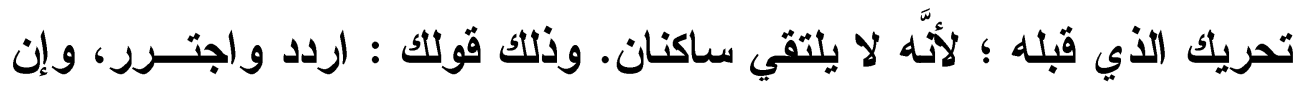

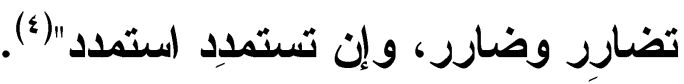

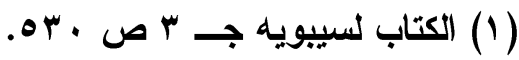

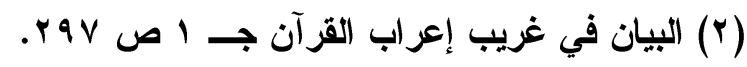

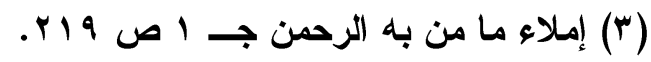

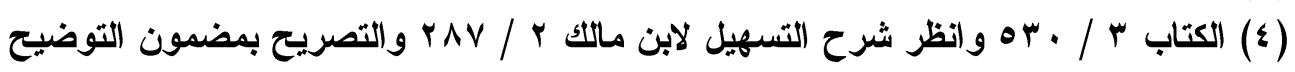

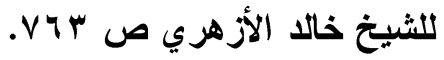


فالعلة في الإظهار عند أهل الحجاز أنَّ ثاني المضعف ســكن بســبب

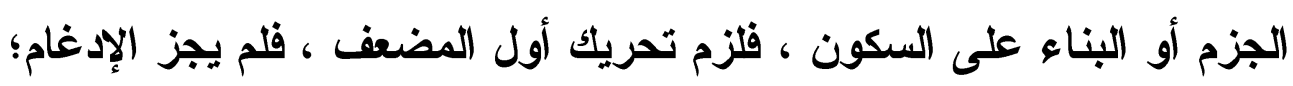

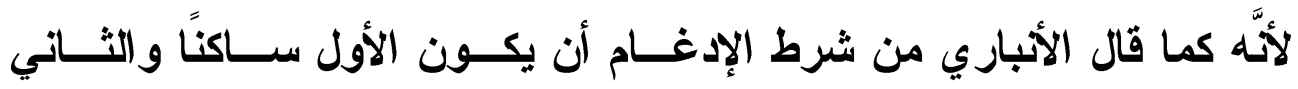

متحركًا، وهنا عكس ذللك (')

اللغة الثانية : الإدغام بتحريك الحرف الأخير بحركة ما قبله ، فيقال:

(لم يرتخَّاَ).

هذا ولعلي أكون قد أوفيت المسألة حقها كما أوفاها حقها إمامنا أبــو

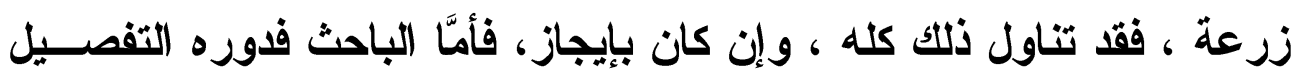

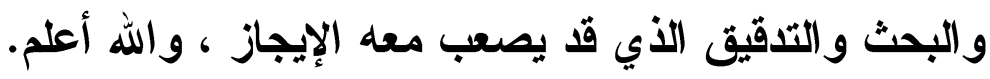

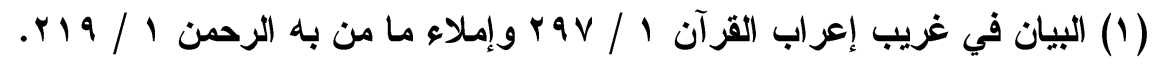




\section{الترقيم الدولم \\ ISSN 2356-9050}

\section{باب الوقف}

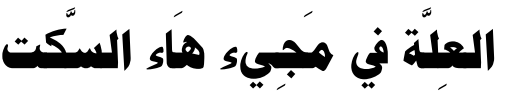

قال الإمام أبو زرعة : (واعلم أنَّ هذه الهاء أدخلت لتبين بها حركة ما قبلها في الوقف إذ المسكوت عليه ساكن فكرهوا أن يسكتوا على الياء ، فلا يفرق بينها وهى متحركة في الوصل وبينها وهى ساكنة في الوصل فبينوا

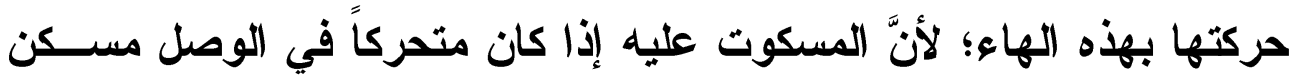

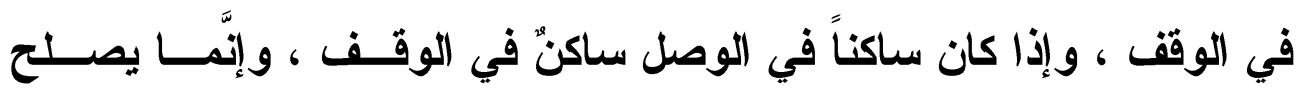
إثبات هاء الوقف في الفواصل ؛ لأَّها مسكوت عليها .على أنَّ دخول الهـــاء (أمارة إذا وصل القارئ الآية بالآية)(') . ما تضمنه كلامه من أفكار :

1 - ذكر أبو زرعة هنا أنَّ علة المجيء بهاء السكت هـي بيـان حركــة

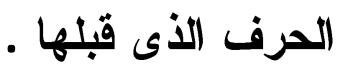

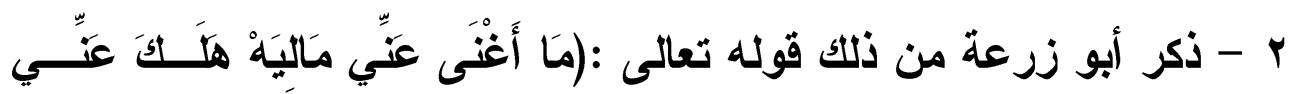

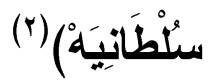
الهاء في" ماليه" "وسلطانيه" جاعت لبيان حركة الياء وهى القتحة . ب- أفاض أبو زرعة هنا في بيان العلة من مجيء هاء السكت ، وقد مــال الأسلوب إلى التكر ار - التص 
التعقيباتُ التّحوية والصّرفية

لأبي زرعة في كِتابِه "حُجَّة القِراكَاتَ"
P199

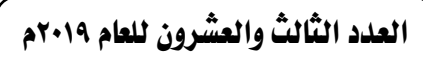

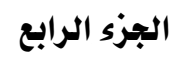

ع - أفاد أنَّ الوقف يسكن الحرف الذى يوقف عليه فلا يلرى هل كان فــي

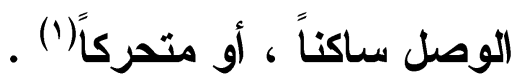

ه - ذكر أنَّ الفواصل يجوز فيها الوصل و الوقف ، وأنَّ الأى سوغ مجـيء

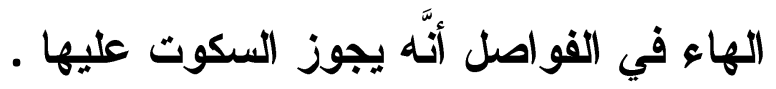

1 - ذكر أنَّ دخول الهاء إذا وصل القارئ في الفواصل إنَّما هو علامة على حركة الحرف الأصلية .

\section{موضع دخول هاء السكت :}

من خصائص الوقف اجتلاب هاء السكت ، ولها ثلاثة مواضع : أحدها : الفعل المعتل (†) المحذوف آخره نحو: ( لم يرمه) .

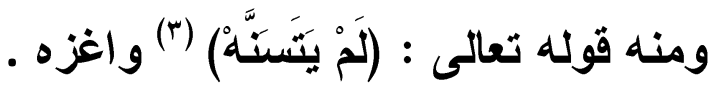

الثاني : بعد" ما" الاستفهامية المسبوقة بحرف جر ، وذلتك أنَّهَ يجـبـ

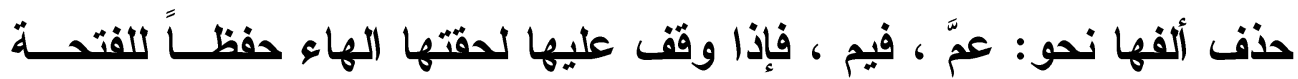

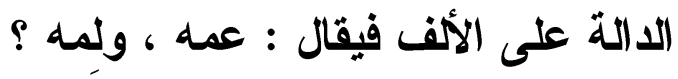
الثالث : كل مبنى على حركة بناء دائماً ، ولم يشبه المعرب وذللك كياء

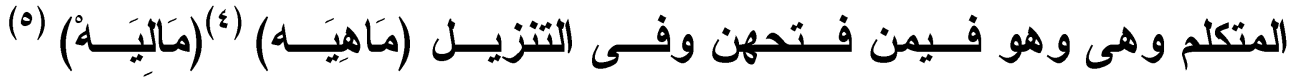

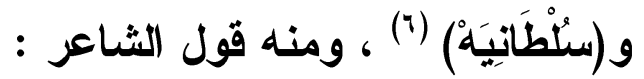

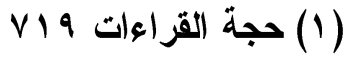

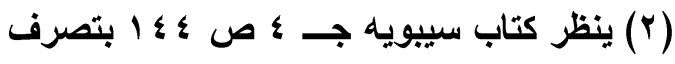

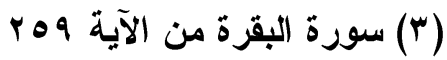

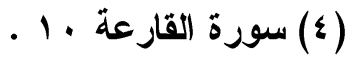

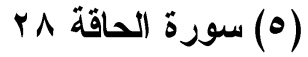

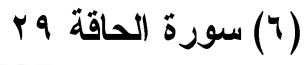




\section{الترقيم الدوله}

ISSN 2356-9050
Tr.

حولية كلية اللفة العربية بجرجا مجلة علمية محكمة

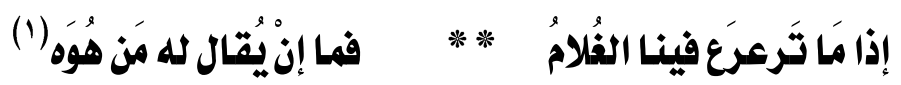

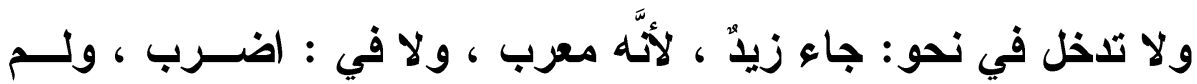

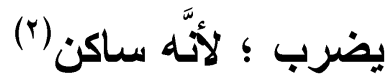

والعلة في مجيء هاء السكت الحفاظ على الحرىـــة إذا بنــى الحــرف الأخير على حركة نحو: مالي وسلطاني، فإنهما مبنيان علــى الفــتح فجــئ بالهاء للحفاظ على القتحة ، ومن لم يفتح لم يأت بالهاء ووقف بالسكون إذ مئ لا فائدة من الإتيان بها.

و إلى هذا أثشار سيبويه حيث ذكر أنَّ العلة في إلحاق الهاء عند الوقف على ما ختم بالياء أنَّهم كرهوا أن يسكنوها إذا لم تكن حرف الإعز ابت وكانت

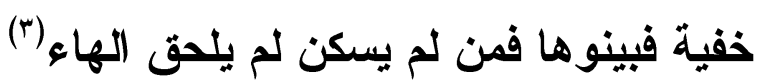
وهذا عين ما ذكره الزمخشري حيث جعل الهاء في (مَا أَغْتَـى عَِّّي

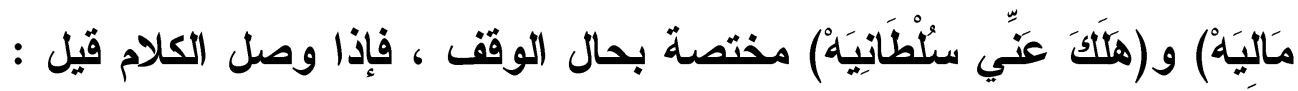

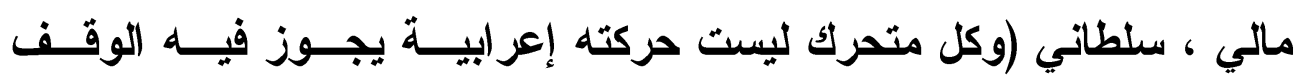

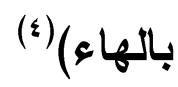

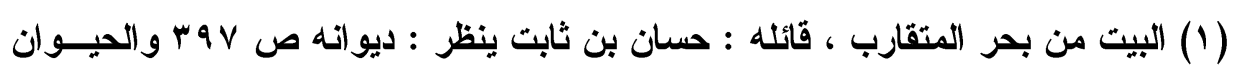

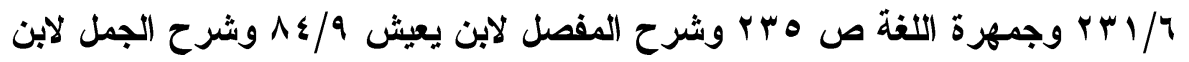

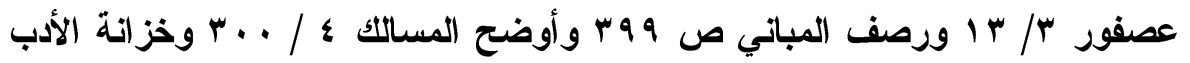

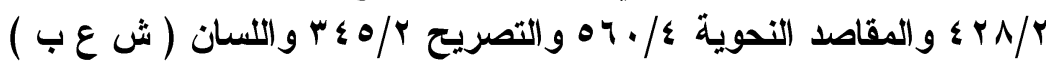

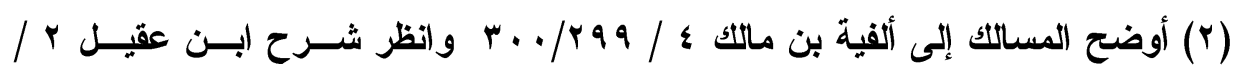

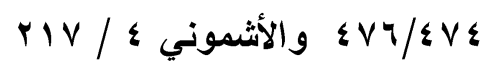

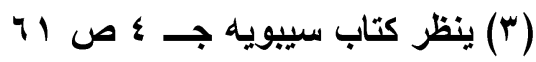

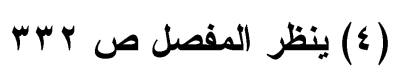




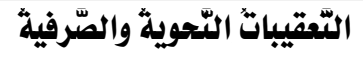

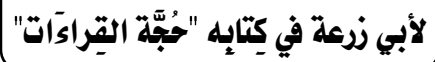

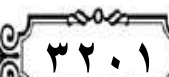

H. T

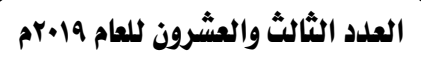

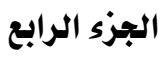

وذكر أنَّ هاء السكت دائماً ساكنة وأن تحريكها لحن ومنه قول الشاعر : (1)

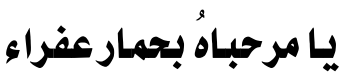

فضم هاء السكت .

وأضاف الزمخشري أنَّ مجيء الهاء في الوصل إجــراء لــهـ مجــرى

الوقف مع تسميته هاء السكت بهاء : الضميز (r)

وقد ذكر (بن يعيش (َ) أنَّ زيادة الهاء تأتىى على ضربين: لازمة وغيـر

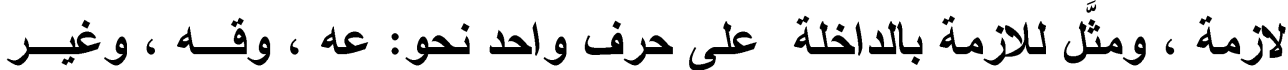

اللازمة إذا دخلت على أكثر من حرف نحو: لثَه ، وفيمه ، وارم ، واغز .

وبعد عرض أقوال بعض النحويين في علة مجيء هاء السكت فإنَّ ما

استطيع الإثارة إليه هنا هو أنَّ ما ذكره أبو زرعة هو ما أدلى به النحويون دون خلاف أو مخالقة ، ثم يبقى الإثارة إلى ما ذكره أبو زرعة مـن ورود هاء السكت في فواصل سورة الحاقة ، فإنَّما هو أمارة وعلامة على الحمى الحركة الأصلية ولتثفق رؤوس الآيات(؛)

(1) البيت من الرجز قائله : عروة بن حزام العذري ينظر : إصلاح المنطق لابن الســكيت

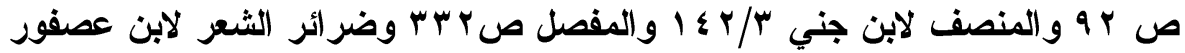

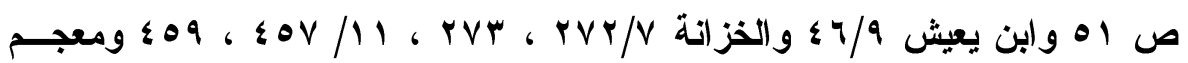

$$
\begin{aligned}
& \text { الثواهد العربية ص بـاه } \\
& \text { (Y) ينظر المفصل ص rrr }
\end{aligned}
$$

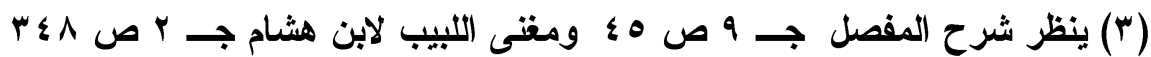

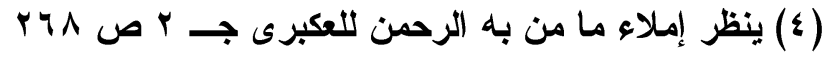




\section{الترقيم الدولم \\ ISSN 2356-9050}

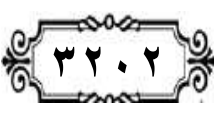

حولية كلية اللفة العربية بجرجا مجلة علمية محكمة

\section{الخـاتمة}

الحمدُ للهِ ربِّ العالمين والصلاة والسلام على إمام الأبيــاء ، وخــاتم

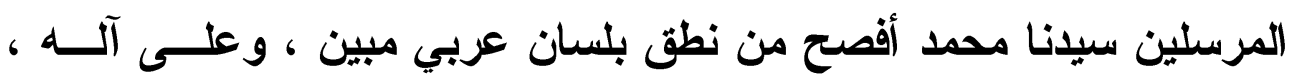

وأصحابه ومن تبعهم بإحسان إلى يوم الاين.

\section{وبـمد :}

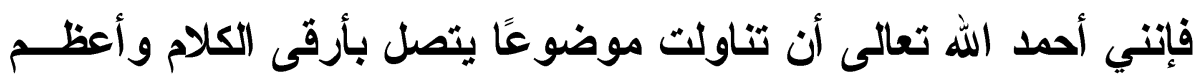

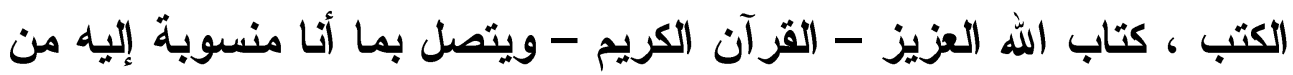
العلوم ، وهو النحو والصرف ، ولعلي أكون قد وفقت في استخراج قضــايا

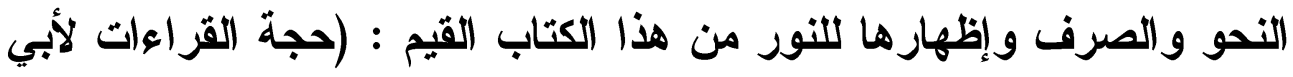

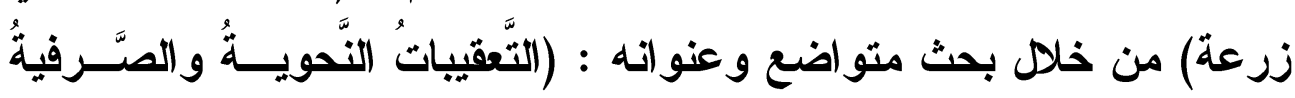

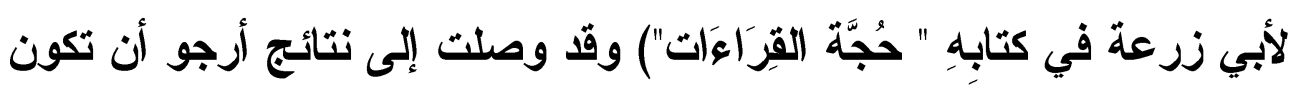
مفيدة لكل من يطالع هذا البحث وتتمثل في :

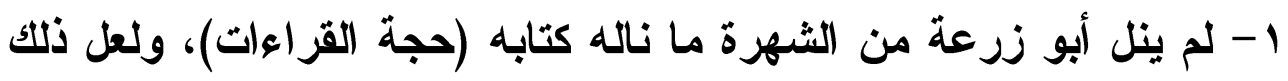

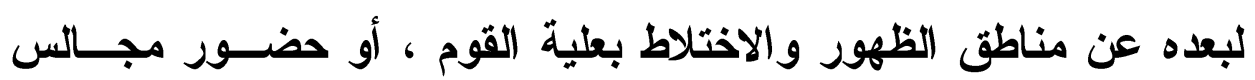
الحكام و الولاة.

r - تبين من خلال البحث إتقان أبي زرعة لقضايا النحو و الصرف و إجادتــه.

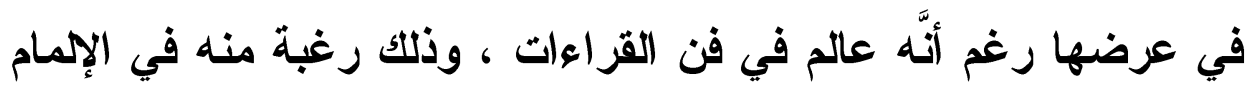
بعلوم العربية ؛ ليتسنى له دراسة كتاب الله وقر اعاتها.

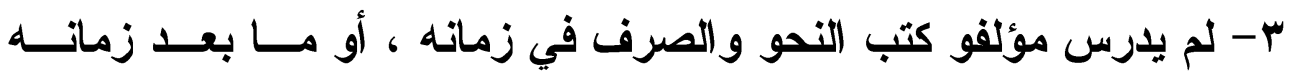

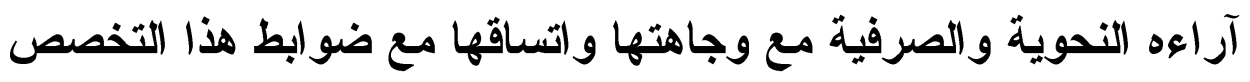

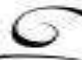


التعقيباتُ التّحويثة والصّرفية لأبي زرعة في كِتابه "حُجَّة القِراءَاتَ"
Pr.r

ritrite

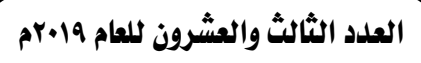

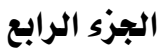

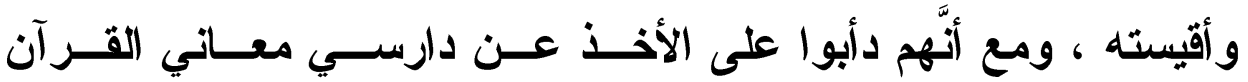
و المفسرين النحويين غيره.

ع - لم أجد في آرائه ما خالف قياسًا ، أو وافق نادرًا وشناذًا.

ه- أكثر أبو زرعة من تناول قضايا النحو والصرف من خــلال التعقيبـات

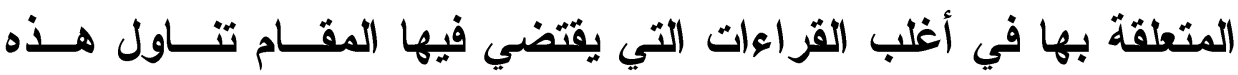
القضايا بجانب التعقيات الأخرى التي تتعلق بالمعنى والالالة والتفسـير

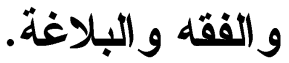

צ- تمثل تعقيباته النحوية والصرفية فكره الخاص به في هذا الجانـب مـن

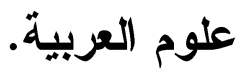

V- تضمنت أغلب التعقيبات قضايا خلافية بين المذاهب ، أو بين النحــيين قل أن يعزو الآراء فيها إلى أصحابها.

^- بعض التعقيبات كان يبدأها برأي أهل النحو بصـفة عامــة ، أو أهـل

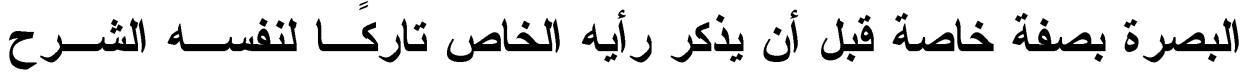

و التحليل والايضاح.

9- ذكر كثيرًا من الأدلة والثواهل مكثراً من شواهد القرآن الكريم ، لا ريب في ذلك فهو عالم متخصص في القزاءات القزآنية. • 1 - ذكر في تعقيباته كثيرًا من الأمثلة التوضيحية التي من خلاهها يــومئ

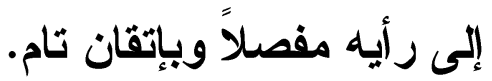

11 - جاء رأيه في كثير من التعقيبات موافقًا للمذهب الكوفي وإن لم يصرح بذكر المذهب الكوفي ، وفي بعضها أيد المذهب البصــري دون ذكــرهم أيضاً.

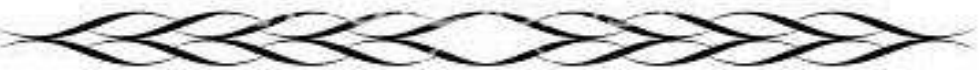




\section{الترقيم الدوله \\ ISSN 2356-9050}

r ا - ذكر أبو زرعة آراء بعض النحويين مصرحًا باســمه ذاكـرًا لنصــهـ كالقر اء والخليل والزجاج والمازني. r ا - استخلم أبو زرعة بعض المصطلحات والأساليب التي غلب استعمالها عند أصحاب المذهب الكوفي ، ولعـل ذلـــ لمعايثــته لهــم واتتثــار مصطلحاتهم عند العلماء وغيرهم كالمواجهة والحاضر بدلاً من الخطاب ، والجزم بدلاً من السكون، والرفع بدلا من الضم. ع ا - مال في بعض التعقيبات إلى الإيجاز اليسير وفي الغالب الأكثــر إلــى التفصيل منتهجًا هذا أو ذاك وفقًا لما تقتضيه طبيعة القضية المتناولة. ه - جاعت التعقيبات خالية من التعقيد في الفكر ، أو الخلط والإضراب في التعبيز ات ، أو الغموض في الألفاظ والتر اكيب.

7 - 1 ذكر أبو زرعة في تعقيباته بعض الأوجه أو الآراء التي قل ورودهـــا في كتب النحو ولعله انفرد بها ، وقد أثرث إلى ذلك من خلال التعقيبـات المشتملة عليها.

وأخيرًا فإنتي أرجو من الله العلي القدير أن يمنحني من عنده القبــول وأن يرضى عني وأن يكتب لهذا البحث السداد والنفع وأن يكــون خالصَّـا لوجهه (لكريم.

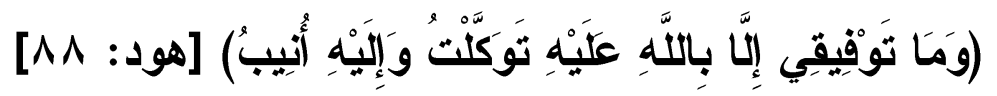

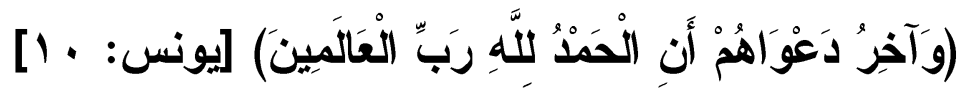




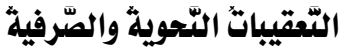
لأبي زرعة في كِتابه "حُجَّة القِراءَاتَ"
Q. $r+0.0$

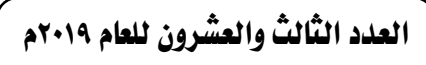

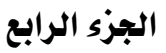

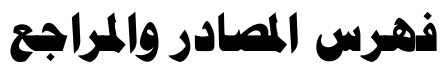

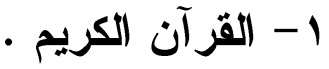

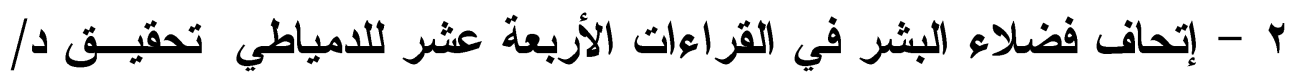

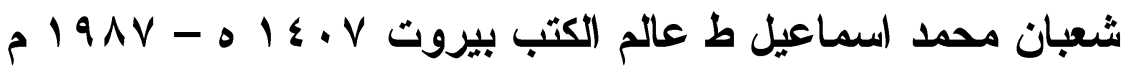
r - ارتثاف الضرب من لسان العرب لأبي حيان ، تحقيق د / رجب عثمان

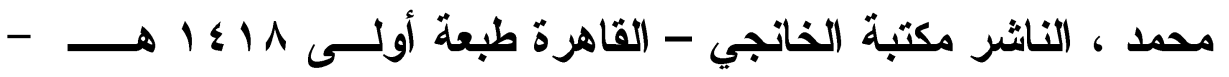

$$
\text { م) } 991
$$

؛ - أسرار العربية للأنباري تحقيق/ محمد بهجت البيطار مطبوعات المجمع

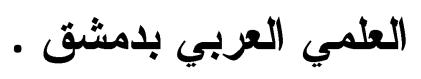

ه- الأصول في النحو لابن السراج ، تحقيق / عبد الحسين الفتيلي - ط -

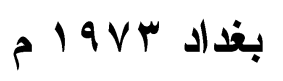

צ- الأعلام للزركلي ط دار العلم للملايين - بيروت

V

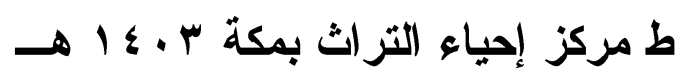

^ - الأمالي الثجرية لابن الثجري تحقيق /عبد السلام هارون ط بيروت .

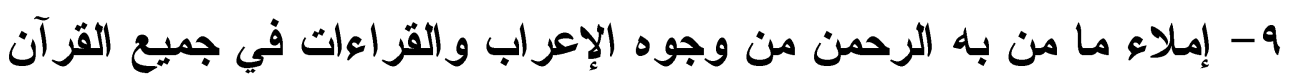

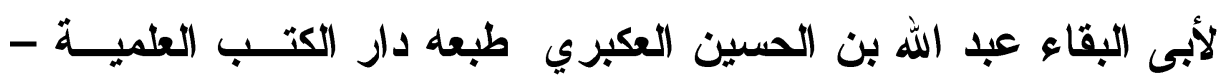

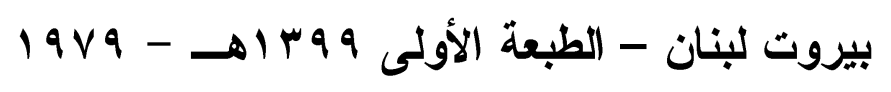

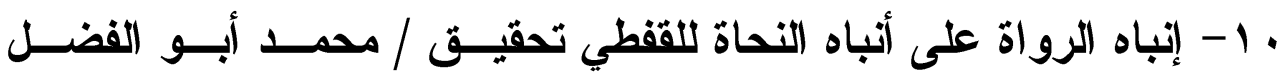

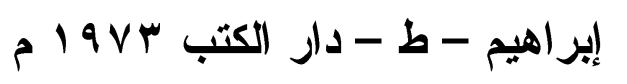

1 - الإنصاف في مسائل الخلاف للأبباري تحقيق / محمد محى الاين عبد

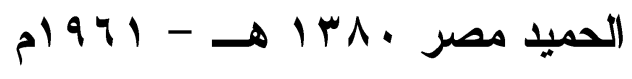




\section{الترقير الدولخ}

ISSN 2356-9050
Q
حولية كلية اللفة العربية بجرجا مجية مجلة علمية محكمة

r 1 - أوضح المسالك إلى ألفية ابن مالك لابن هشام ومعه كتاب عدة السالك إلى تحقيق أوضح المسالك تأليف / محمد محى الاين عبد الحميـد - ط

دار الطلانع

r ا - بغية الوعاة في طبقات اللغويين والنحاة للسيوطي تحقيق / محمد أبو

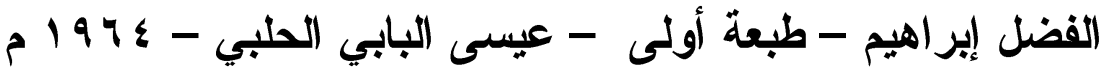
ـ ا - البيان في غريب إعراب القرآن لأبي البركات الأبلاري تحقيق / طـــهـ عبد الحميا طله ، ومصطفى السقا الناشر - الهيiٔسة المصــرية العامـــة

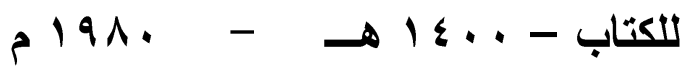

ه - تاريخ الأدب العربي لبروكلمان ، ترجمة د / عبـــ الحلـيم النجــار ،

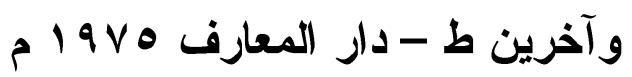

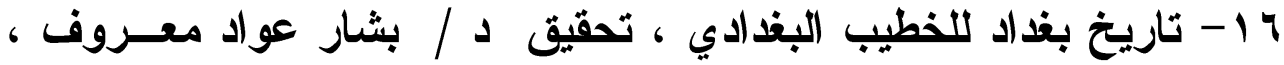

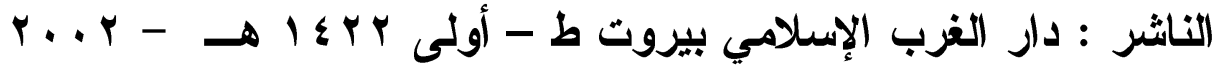

IV - التبصرة والتنكرة للصيمري تحقيق د / فتحي أحمد مصطقى - الناشر - مركز البحث العلمي وإحياء التراث الإســلامي - ط - أولــى بـ + ع 1

$$
\text { ه }
$$

1 ا - تذكرة النحاة لأبي حيان ، تحقيق د / عفيـف عبـــ الــرحمن - ط مؤسسة الرسالة - بيروت - طبعة أولى - 7 . ع 1919 هـ 1919 م 9 - التذييل والتكميل في شرح التسهيل لأبي حيان ، تحقيـق د / حسـين

$$
\text { هنداوي ، الناشر : دار القلم - دمشق - ط - أولى }
$$

• r - التصريح بمضمون التوضيح للثيخ خالد الأزهري ط عيســى البــابي

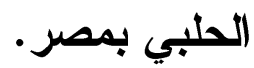




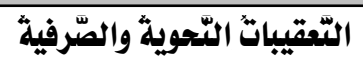

لأبي زرعة في كِتابه "حُجَّة القِراءَات"

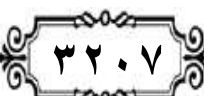

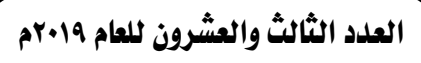
الجزء الرابع العئرون

اب - التصريف الملوكي لابن جني تحقيق / عرفان مطرحسي - الناثــر مؤسسة الكتب الثقافية .

r r - تفسير البحر المحيط لأبي حيان الألدلسي تحقيق / الثيخ عادل أحمـــ عبد الموجود ، والثيخ علي محمد معوض - طبعة - دار الكتب العلمية

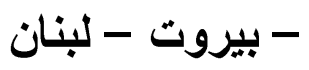

بr - تفسير الكثاف للزمخثري تعليق / خليل مسأمون شــيحة - ط - دار

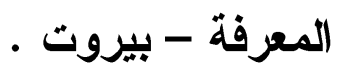

ع ب - التكملة لأبي علي الفارسي تحقيق / حسن شاذلّي فرهود - الناشر -

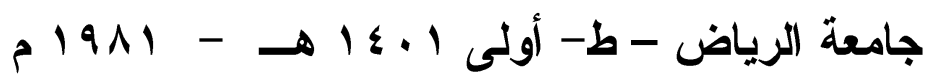

هـ - الجامع لأحكام القرآن ( تفسير القرطبي ) تحقيق / عبد الله بن عبــ

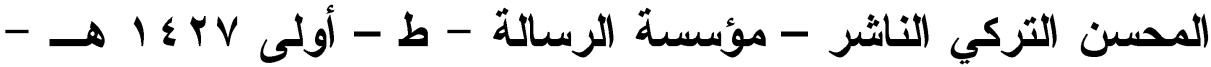

$$
\text { 5r. Th }
$$

YY Y - الجمل للزجاجي تحقيق ابن أبي شنب مكنسكسيك بياريس

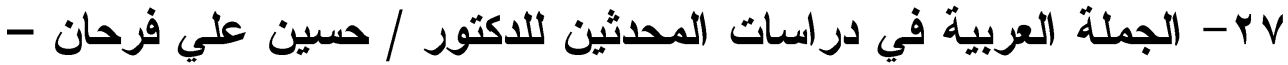

$$
\text { طبعة - دار الكتب العلمية - بيروت في درات الجئ }
$$

1 - الجنى الادي في حروف المعاني للمرادي تحقيق د/ فخر الدين قباوة ،

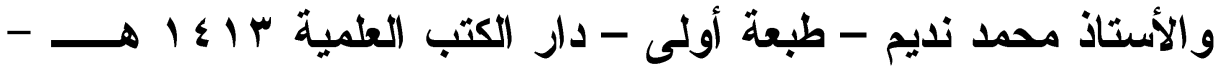

$$
\text { م } 1994
$$

q ץ - حاثية ابن حمدون على شرح المكودي على ألفية ابن مالك - طبعـة

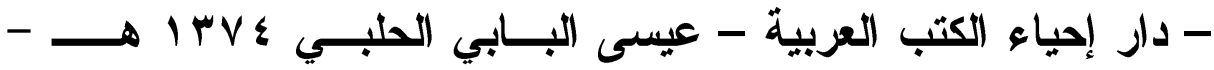

$$
\text { م } 1900
$$

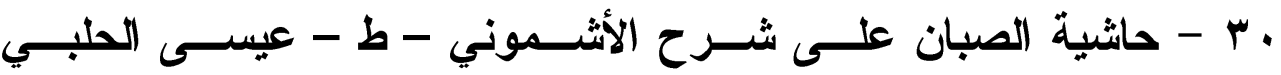

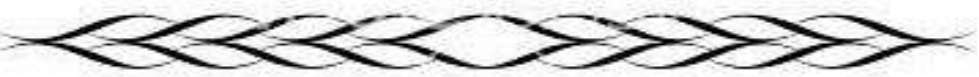




\section{الترقيم الدوله \\ ISSN 2356-9050}

اب- حجة القزاعات لأبى زرعة تحقيق سعيد الأفغاني مؤسسـة الرســالة

$$
\text { p) } 99 V \rightarrow 1 \leq 11
$$

r r - حروف المعاني للزجاجي ، تحقيق د / علــي قاســم الحمـــ - ط مؤسسة الرسالة - مكتبة لسان العرب - الأردن

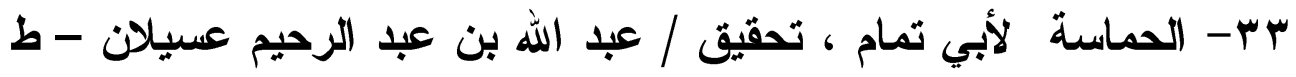

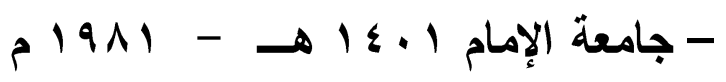

ـ ب- الحضارة الإسلامية ( دراسة العلوم الإسلامية ) تأليف د / طــه عبـــ

المقصود عبد الحميد أبو عبية ، منشورات - المكتبة العلمية بيروت -

\section{لبنان}

هـ - الحلل في شرح أبيات الجمل لابن السيد البطليوسي ، تحقيق / يحسي

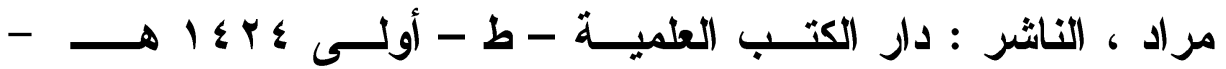

$$
\text { مr. r }
$$

جس - الحياة العلمية في الثنام والعراق في القرن الرابع الهجــري ، لكــرم

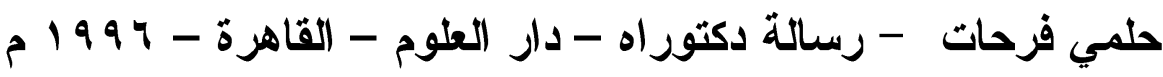
א rV

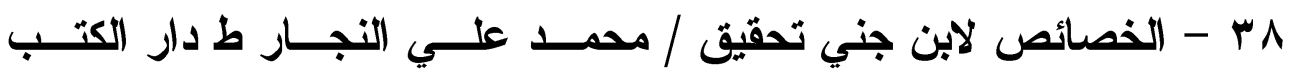
S IrvT

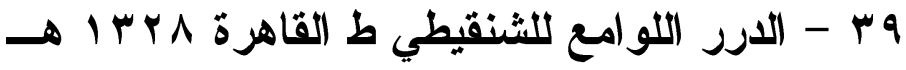
، ـ - دروس التصريف ، تأليف / محمد محي الاين عبد الحميا - الناسـر

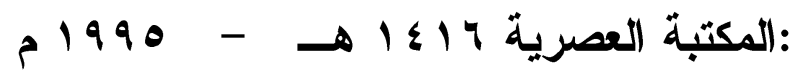

اء - دليل السالك شرح ألفية (بن مالكك /عبد الله الفوزان ، الناشـر : دار

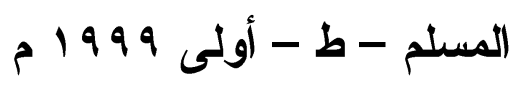

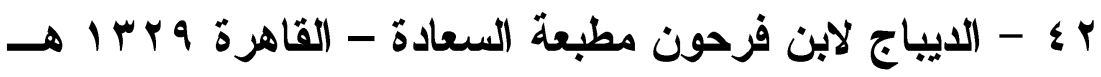




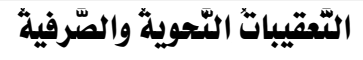
لأبي زرعة في كِتابهه "حُجَّة القِراكَاتِ" rr.

r. 9 .

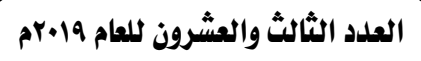

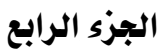

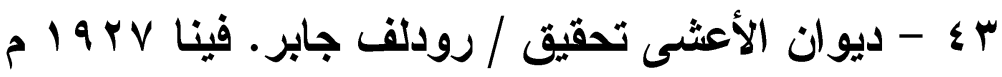
ـ ـ - ديوان جران العود عامر بن الحارث تحقيق / نوري القيسي .

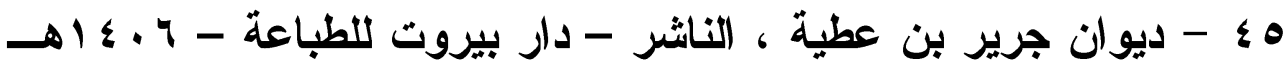
1919\ء - رصف المباني في شرح حروف المعاني للمالقي تحقيق/ أحمد محمد

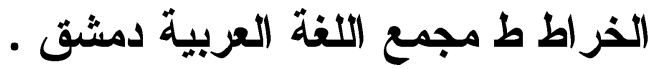

\& V - روح المعاني للألوسي ، تحقيق / علي عبد الباري عطية ، الناشر :

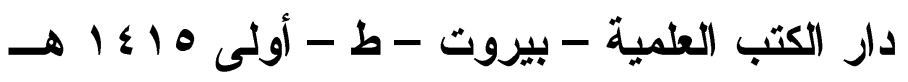

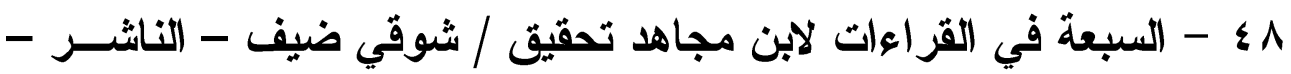

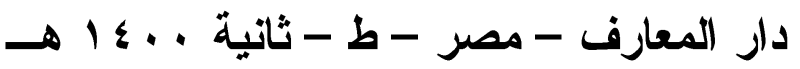

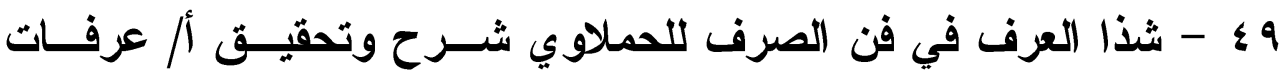

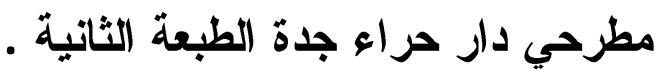
•ـ - شذرات الأهب في أخبار من ذهب لابن العماد ط - المكتبة التجاريـــة

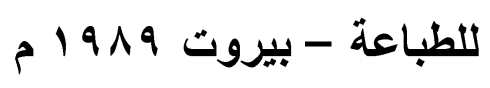

1ه - شرح أبيات سيبويه للسير افي تحقيق / محمد علي الريح ، وطه عبد

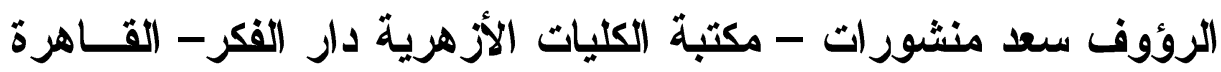

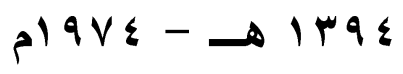

r r - شرح الأفية لابن عقيل تحقيق/ محمد محى الدين عبد الحميد ط دار

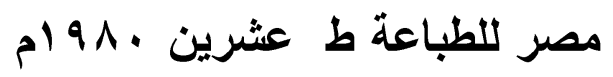

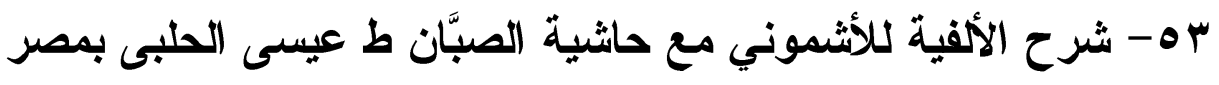

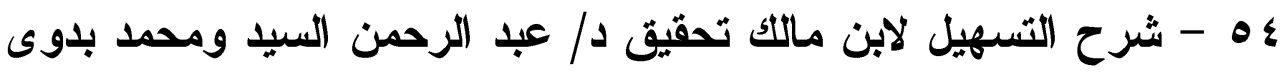
المختون ط مطبعة هجر بالقاهرة

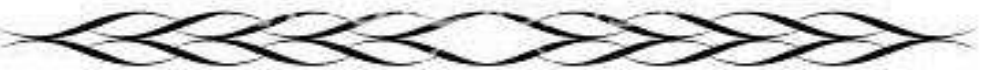




\section{الترقير الدوله \\ ISSN 2356-9050}

هـ - شرح التصريف العزي الثريف الجرجاني تحقيق د / أسيده شهيندر

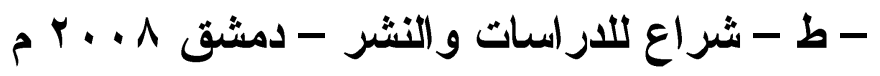

צه - شرح جمل الزجاجي لابن عصفور تقديم / فواز الشعار - منشورات

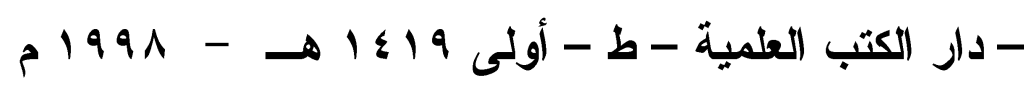

هV - شرح شذور الأهب في معرفة كلام العرب لابــن هشــام الأنصــاري تحقيق / محمد أبو الفضل عاشور - الناشر : دار إحياء التراث العربي

$$
\text { - ط - أولى r... }
$$

ه - شرح ديوان الحماسة للمرزوقي تحقيق / غريد الثــيخ ، الناشــر -

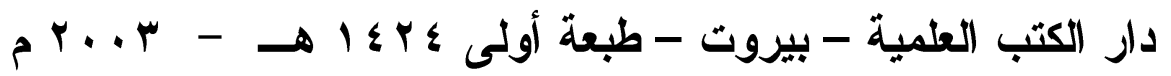
9ه - شرح شاقية ابن الحاجب للرضى/ تحقيق محمد نور الحسن وآخرين

$$
\text { ط دار الكتب بيزوت . }
$$

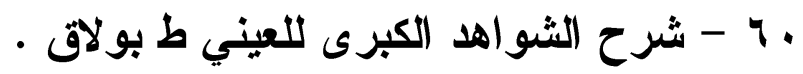
1 - شرح شواهد المغني للسيوطي تحقيق / أحمد ظافر كوجان ، الناشــر

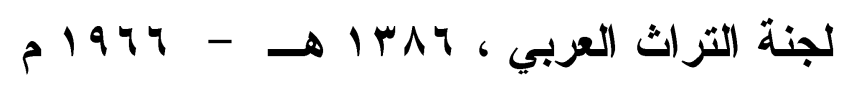

r Y - شرح كافية ابن الحاجب للرضي /طبعة دار الكتب العلميــة بيـروت

\section{لبنان}

ب

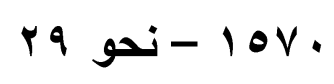

ء - شرح اللمع في النحو للواسطي الضريز ، تحقيق / رجب عثمان محمد

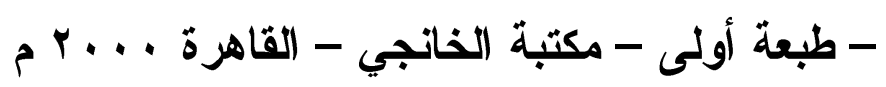

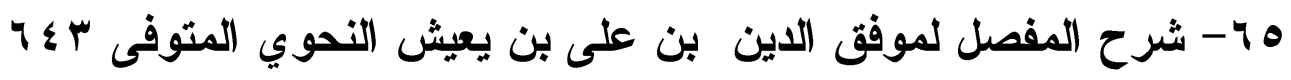

$$
\text { طبعة مكتبة المتنبي القاهرة }
$$

7 7 - الشعر والشعراء لابن قتيبة ، الناشر : دار الحديث القاهرة . 

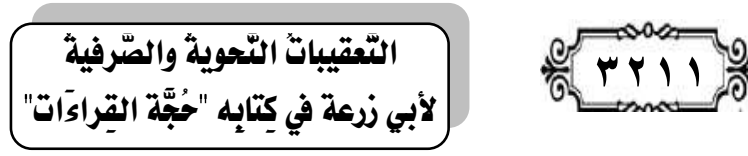

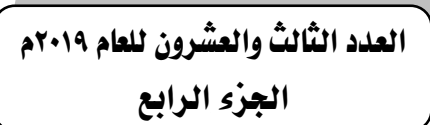

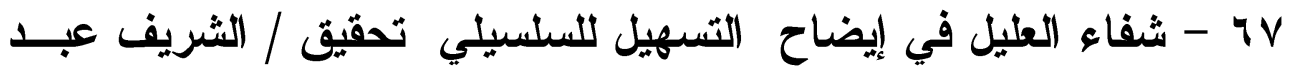

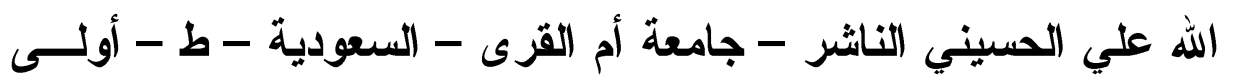

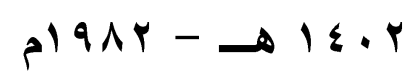

1 - ضر ائر الثعر لابن عصفور تحقيق / السيد إبراهيم محمد - ط - دار

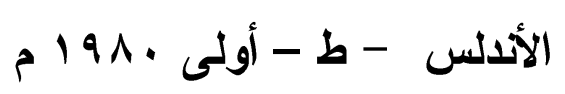

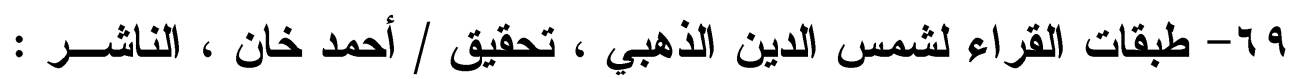

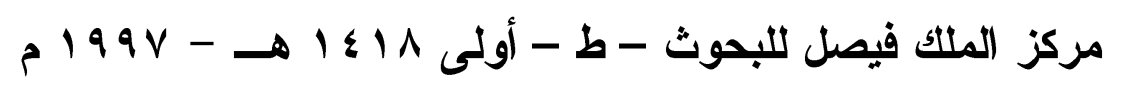

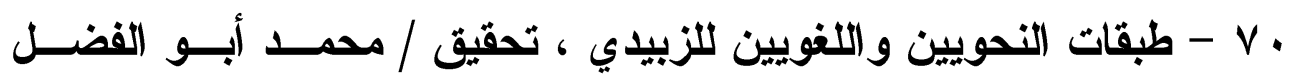

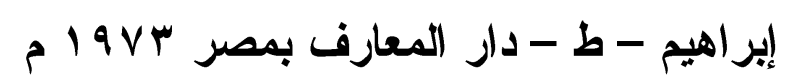

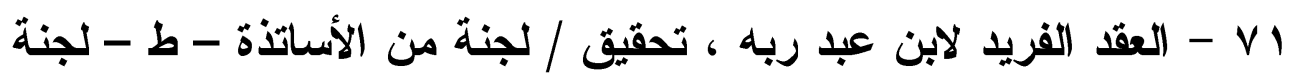

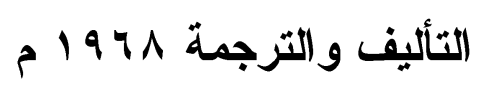

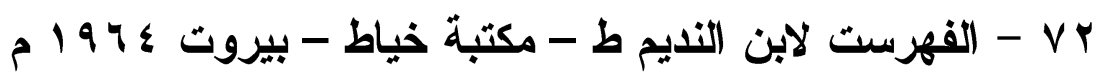
الكتاب لسيبويه تحقيق /عبد السلام هارون ط الخانجي القاهرة - Vr

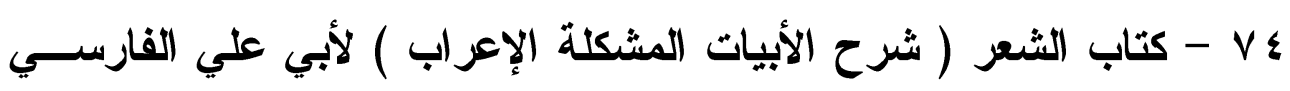

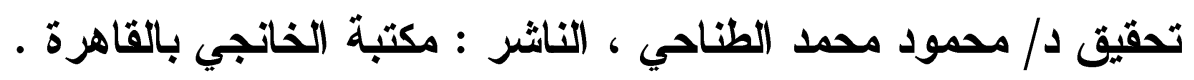

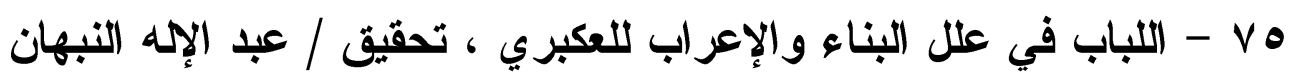

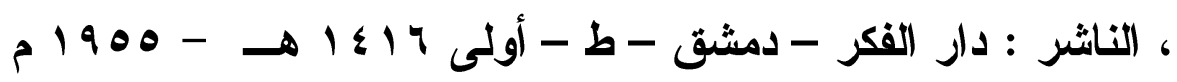

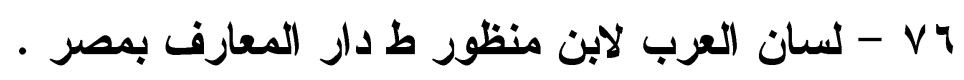

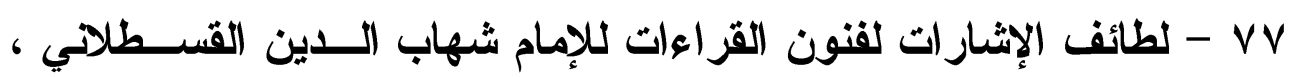

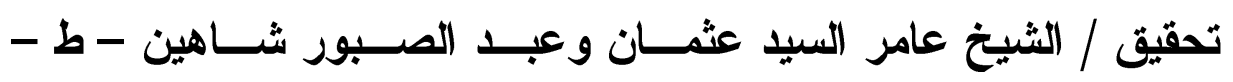

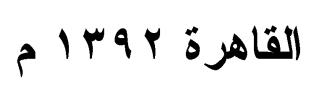

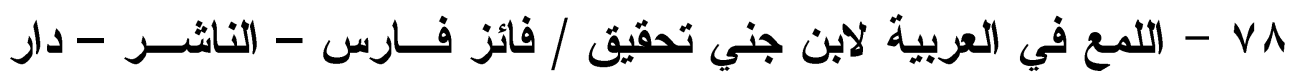

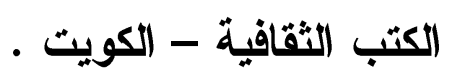




\section{الترقير الدوله \\ ISSN 2356-9050}

Vq - المتبع في شرح اللمع للعكبري دراسة وتحقيق د/ عبد الحميد حمــ

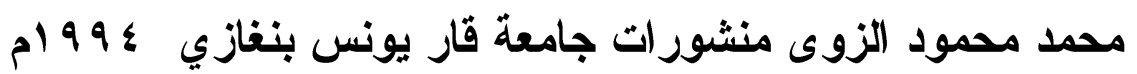

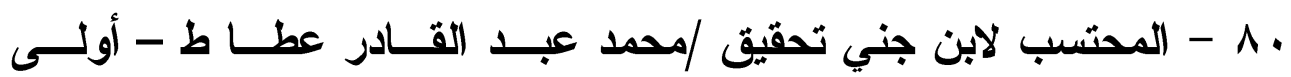

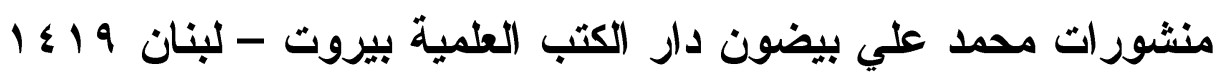

$$
\text { م 1991-0 }
$$

1 - مختصر في شواذ القرآن من كتاب البديع لابن خالويه - ط - مكتبة

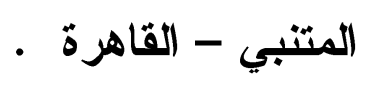

Y r - المدارس النحوية ، تأليف د / شوقي ضيف ، الناشر : دار المعارف

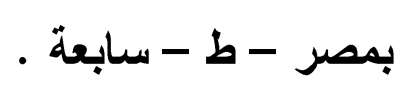

بی - مرآة الجنان وعبرة البقظان لليافعي ، تحقيث / خليل المنصــور - ط

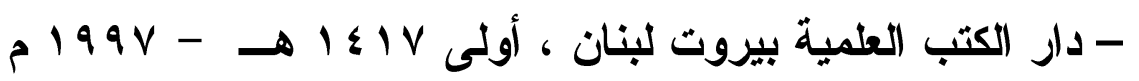
ع - مراح الأرواح في علم الصرف لأحمد بن علي بن مسعود - طبعة -

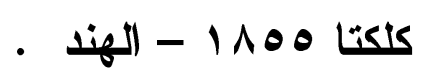

ه - المرشد الوجيز إلى علىم تتعلق بالكتاب العزيز لشهاب الــدين عبـــ الرحمن المعروف بأبي شامة ، تحقيق / طيار آلتي قــولاج - ط - دار

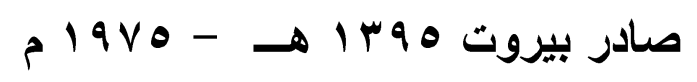

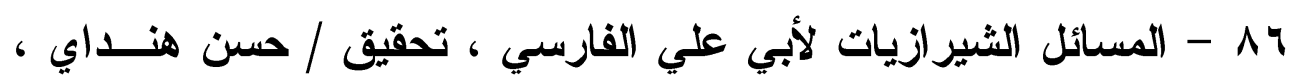

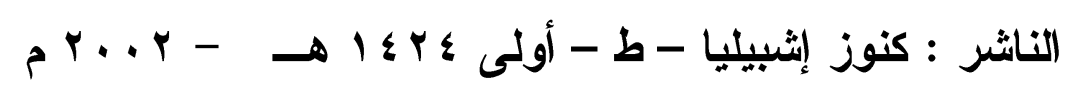

NV

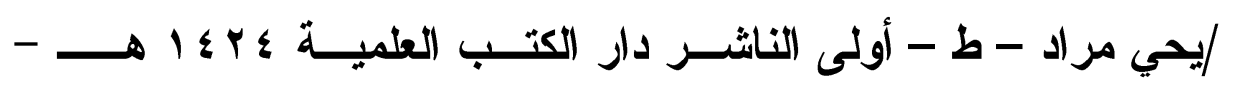

$$
\text { م r...r }
$$

\section{6}



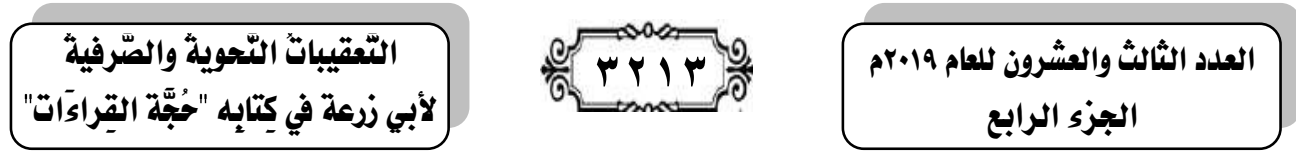

^^ - المسائل المنثورة لأبي علي الفارسي ، تحقيق / شريف عبد الكــريم

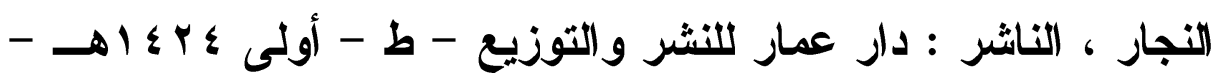

$$
\text { م... }
$$

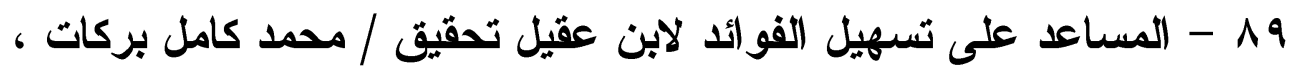

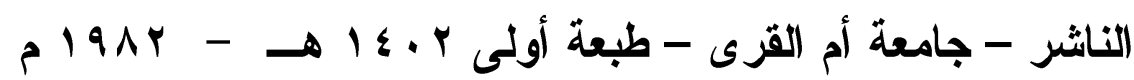

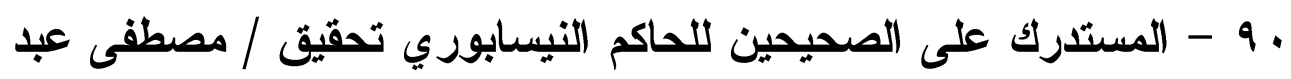

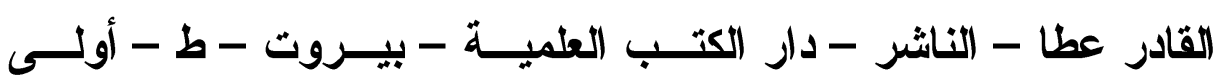

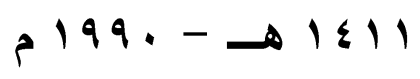

19 - مشكل إعراب القرآن لمكي بن أبي طالب تحقيق/ ياسين العــواس ط دار المأمون للتراث إعزئ

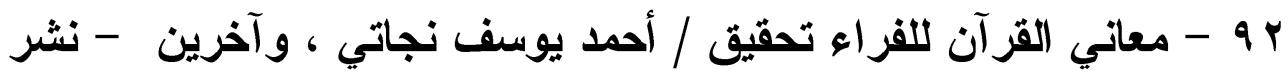

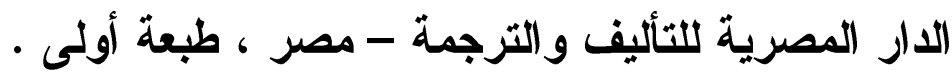

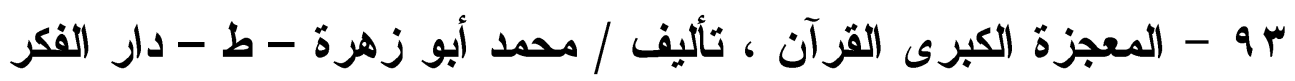

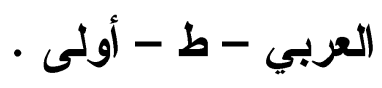

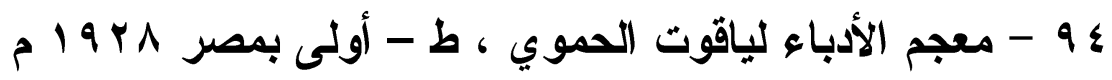

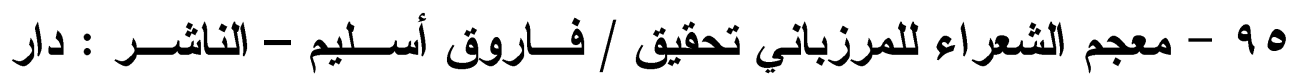

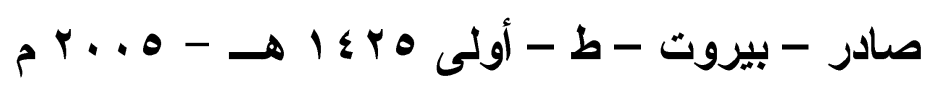

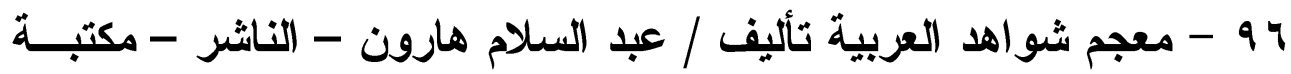

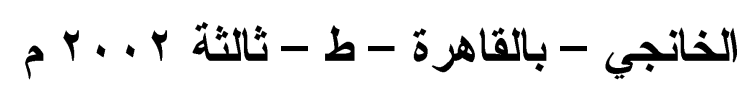

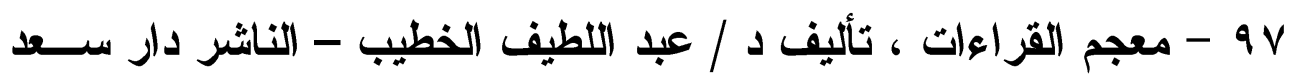

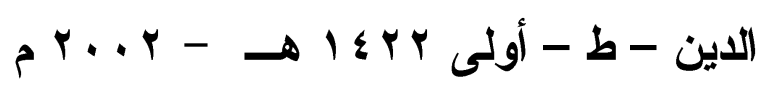

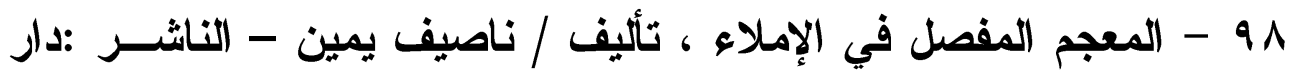

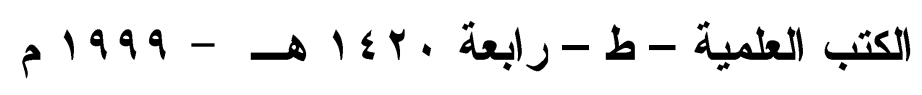




\section{الترقيم الدولم \\ ISSN 2356-9050}

9 - مغتي اللبيب لابن هثام الأكصاري تحقيق/ محمد محــى الــدين عبـــ الحميد ط محمد على صبيع بالأزهر القاهرة . . - المفصل للزمخثري ط دار الجيل الطبعة الثانية . 1 . 1 - المقاصد الشافية في شرح الخلاصة الكافية للثاطبي تحقيق / عبد الرحمن بن سلمان العثيمين ، وآخرين - الناشر : جامعة أم القرى - ط له

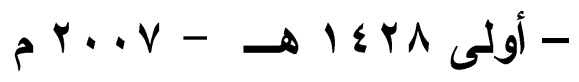

r • 1- المقاصد النحوية في شرح شواهد الأفية للعيني تحقيـق د / علــي محمد فاخر وآخرين - الناشر - دار السلام للطباعة - القـاهرة - ط ل

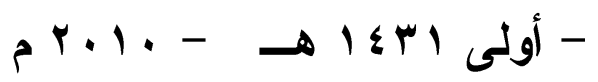

r • 1 - المقتضب للمبرد تحقيق /محمد عبد الخــالق عضــيمة ط المجلـس

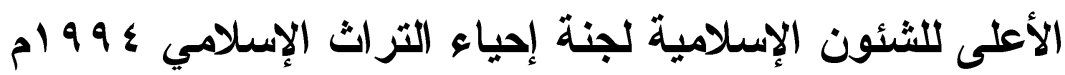

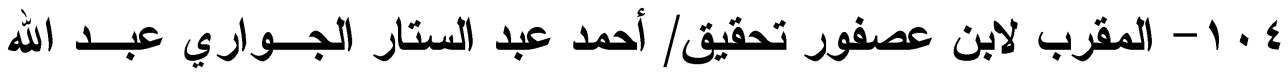
الجبوري بغداد مطبعة العاني ط الأولى IVI هـ 1 - الممتع الكبيز في التصريف لابن عصفور تحقيق الاكتور / فخــر الاين قباوة - الناشر - مكتبة لبنان - طبعة أولى 1999 م 19 7 . 1 - منجد المقرئين ومرشد الطـالبين لابــن الجـزري - ط - مكتبــة القدوس V - ا - المنصف لابن جني تحقيق إبـر اهيم مصــطفى وعبـــالله أمسـين ط الحلبي أه 1 . 1 - منهج السالك في الكلام على ألفية ابن مالك لأبي حيــان الأندلسـي تحقيق / شريف عبد الكريم النجار ، الناشر : عالم الكتب الحـديث - ط

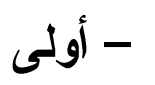

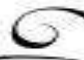



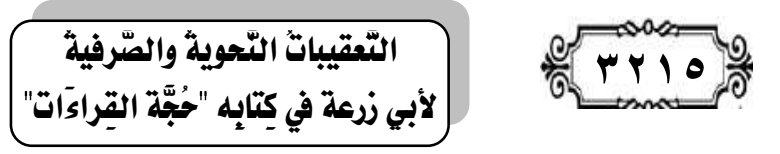

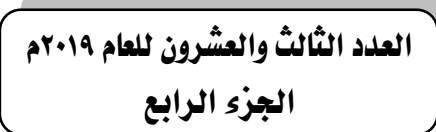

9 . 1 - نزهة الألباء في طبقات الأدباء لابــن الأبــاري - ط - المطــابع

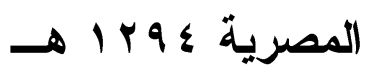

ـ 11- نزهة الطرف في علم الصرف لابن هثام تعقيق/ أحمد عبد المجيــ

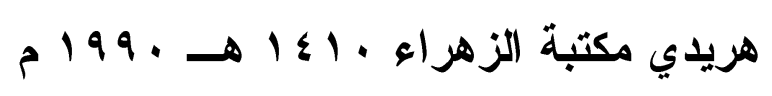

111

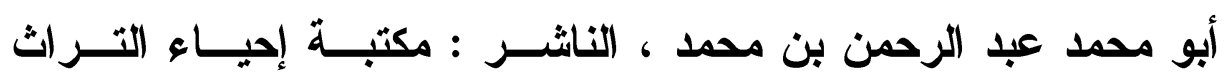

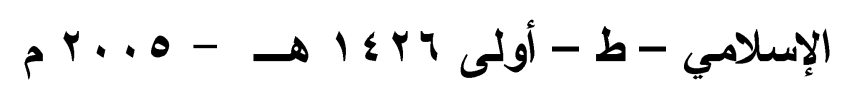

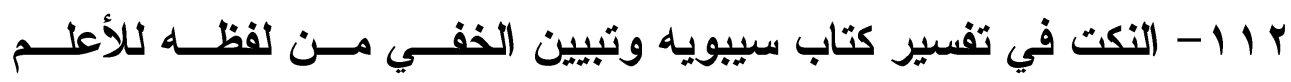

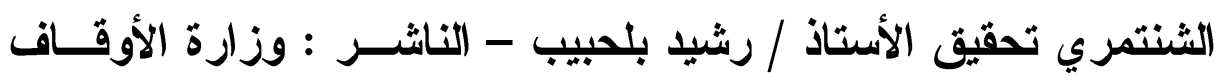

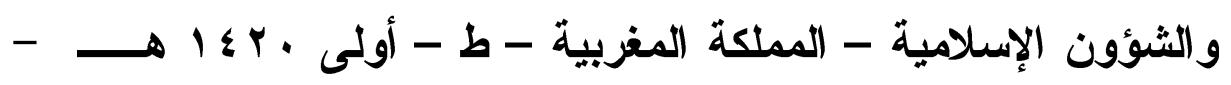

$$
\text { م } 1999
$$

111 - النشر في القزاءات العشر لابن الجزري تصحيح / علي محمد محمد

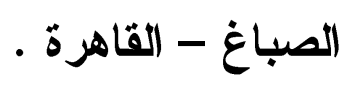

؛ 1 - همع الهوامع شرح جمع الجوامع للسيوطي نشــر مكتبــة الكليــات

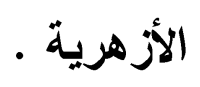

11 1 - وفيات الأعيان وأنباء أبناء الزمان لابن خلكان ، تحقيق د / إحسان

$$
\text { عباس - ط - دار صادر بيروت . }
$$

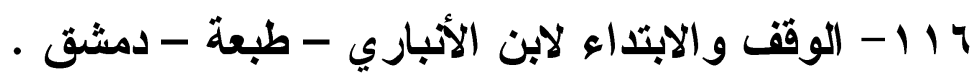

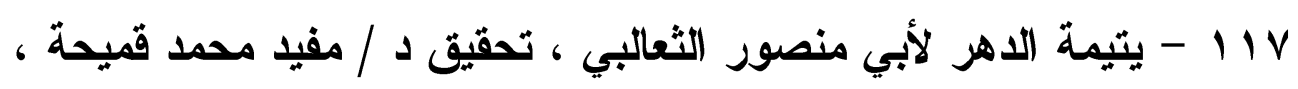

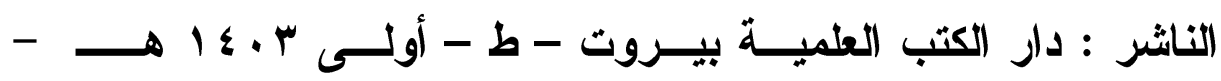

$$
\text { raیr }
$$

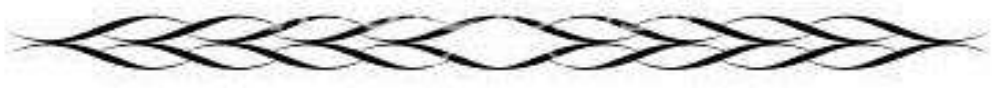




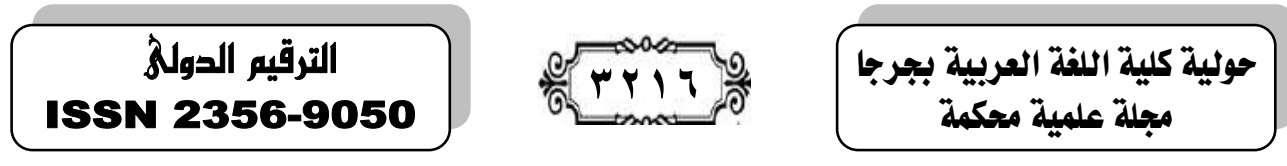
فهرس الموضوعات

\begin{tabular}{|c|c|}
\hline الصفمة & الإوضوع \\
\hline 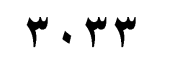 & لا \\
\hline ه. & Research Summary \\
\hline r. rV & \\
\hline 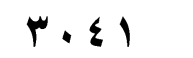 & \\
\hline$\Psi \cdot \varepsilon 1$ & 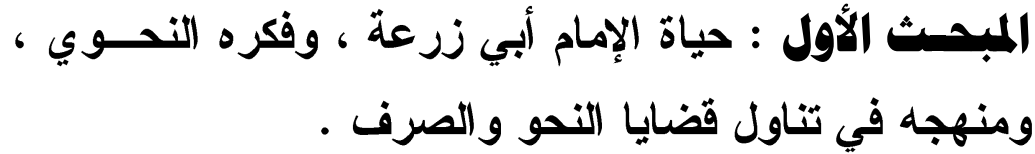 \\
\hline$\mu .07$ & ب : نبذة عن علم القراعات ، والتــأليف فـي \\
\hline$r .7 r$ & تعقيبات أبي زرعة النحوية. \\
\hline 191 & الثانى : تعقيبات أبي زرعة الصرفية. \\
\hline$r r \cdot r$ & \\
\hline$r r \cdot \theta$ & در والمراجع \\
\hline rrit & و ت وعات \\
\hline
\end{tabular}

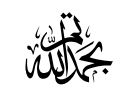

